\title{
Traducción y recepción universal de Benito Pérez Galdós: cien años después (1920-2020)
}

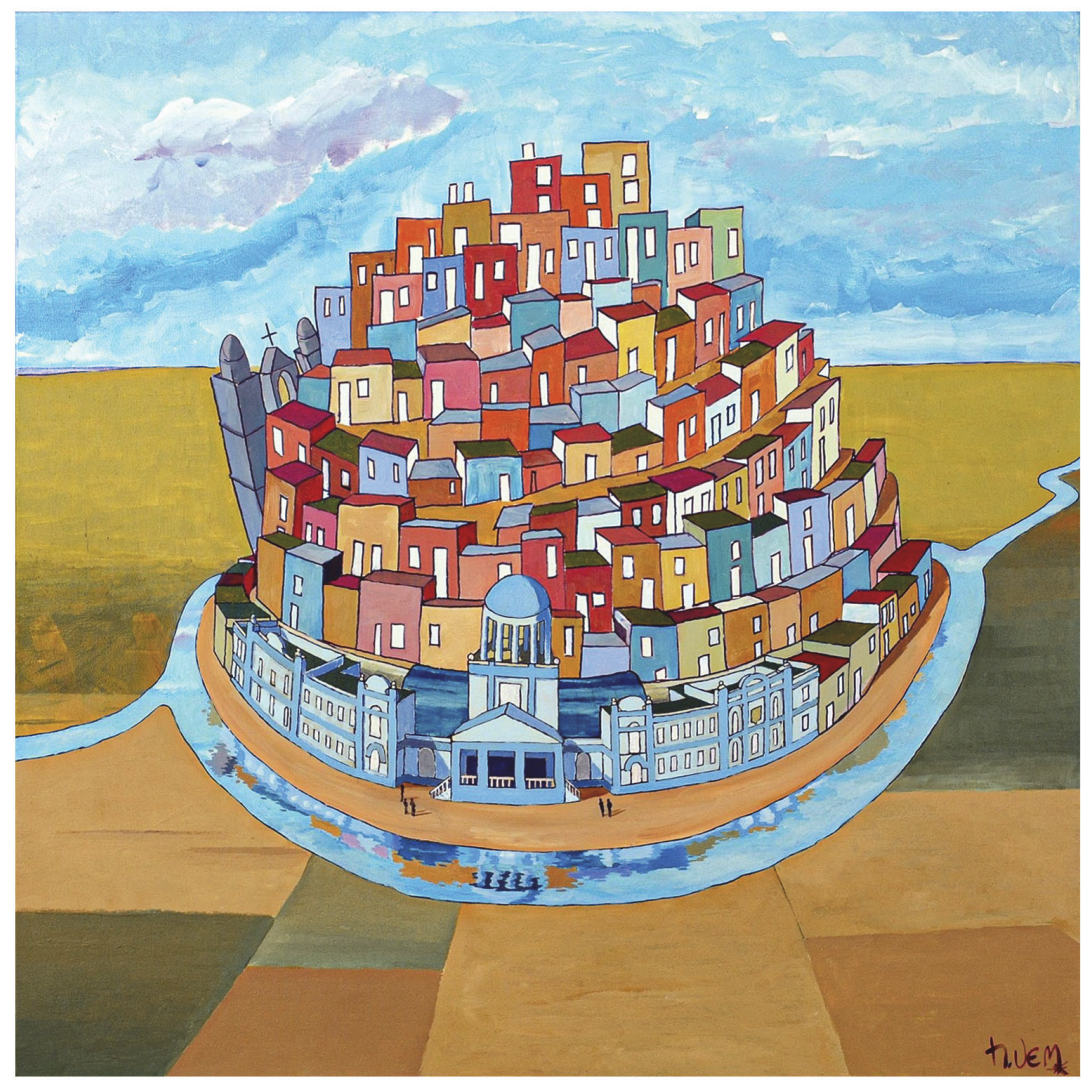

Juan Miguel Zarandona Fernández (Coord.) 

Traducción y recepción universal de Benito Pérez Galdós: cien ańos después (1920-2020) 


\title{
COLECCIÓN
}

\section{TIBÓN: ESTUDIOS TRADUCTOLÓGICOS}

\author{
DiRECCIÓN DE LA COLECCIÓN
}

Isabel Pascua Febles (ULPGC)

\section{COMITÉ CIENTÍFICO-ASESOR}

Baigorri, Jesús (USAL); Carbonell, Ovidi (USAL); García de Osuna, Alfonso (Hofstra University, NY); Hurtado Albil, Amparo (UAB); Mayoral Asensio, Roberto (UGR); Oittinen, Riitta (U. Tampere); Presas Corbella, Marisa (UAB); Silvia Bernardini (U. de Bolonia); Vidal Claramonte, C. África (USAL); Wotjak, Gerd (U. Leipzig).

\section{COMITÉ CIENTÍFICO-EVALUADOR}

Acuña Partal, Carmen (UMA); Agost Canós, Rosa (UJI); Alonso Aragúas, Icíar (USAL); Alvstad, Cecilia (U. Oslo); Arencibia Santana, Yolanda (ULPGC); Ariza, Mercedes (FUSP); Arias Torres, Juan Pablo (UMA); Batista Rodríguez, José J. (ULL); Bazzocchi, Gloria (U. Bolonia); Botella Tejera, Carla (UA); Chaume, Frederic (UJI); Chiara Russo, María (U. Bolonia); Cornelio, María (CUNY, Hunter College, NY); Cruces Colado, Susana (UVIGO); Czulo, Oliver (U. Leipzig); Di Giovanni, Elena (U. Macerata); Díaz Cintas, Jorge (London University College); Espasa Borrás, Eva (UVIC); Feria García, Manuel (UGR); Fernandez Padilla, Gonzalo (UAM); Flores, Jean Marie (U. PAU); Franco Aixelá, Javier (UA); Galván González, Victoria (Casa-Museo Pérez Galdós); García de Toro, Cristina (UJI); García Izquierdo, Isabel (UJI); García Vinuesa, Maya (UAL; González Davies, María (URLL); Hernández Socas, Elia (ULL); Iliescu Gheorghiu, Catalina (UA); Gallardo San Salvador, Natividad (UGR); Hernández Guerrero, María José (UMA); Jiménez Crespo, Miguel A. (Rutgers U.); Jiménez Hurtado, Catalina (UGR); Ketola, Anne (U. Tampere); Lorenzo García, Lourdes (UVIGO); Marco Borillo, Josep (UJI); Marrero Aguiar, Victoria (UNED); Martín Ruano, Rosario (USAL); Mateo-Martínez Bartolomé, Marta (UNIOVI); Mellinger, Christopher (U. North Carolina); Montero Küpper, Silvia (UVIGO); Morillas García, Esther (UMA); Muñoz Martín, Ricardo (U. Bolonia); Neves, Joselia (HBKU); Oliver Frade, José M. (ULL); Orrego Carmona, David (Aston U.); Payás Puigarnau, Gertrudis (U. Católica de Temuco, Chile); Pegenaute Rodríguez, Luis (UPF); Peña Martín, Salvador (UMA); Pereira, Ana (UVIGO); Pérez García, Jesús (UVA); Pérez García, José Miguel (ULPGC); Rodríguez García, Alba (UGB, Senegal); Ruzicka Kenfel, Velijka (UVIGO); Samson, Richard (UVIC); Sánchez Gijón, Pilar (UAB); Santaemilia Ruiz, José (UV); Santana López, Belén (USAL); Sun, Sanjun (Beijing Foreign Studies University); Sarmiento Pérez, Marcos (ULPGC); Tabares Plasencia, Encarna (U. Leipzig); Thépaut, Èlise (U. Liquès de Pimquer); Tiselius, Elizabeth (U. Bergen); Toledano Buendía, Carmen (ULL); Tonin, Raffaela (U. Bolonia); Travalia, Caroline (HWS Colleges, Geneva, NY); Valero Cuadra, Pino (UA); Witte, Heidrun (ULPGC); Zabalbeascoa Terran, Patrick (UPF); Zarandona Fernández, Juan M. (UVA); Zitawi, Jehan (Abu Dhabi U.).

\section{CONTACTO}

tibon@ulpgc.es 
Traducción y recepción universal de Benito Pérez Galdós: cien años después (1920-2020)

Juan Miguel Zarandona Fernández (Coord.)

Lieve Behiels, Amalia Bosch Benítez, Pilar Martino Alba, Assunta Polizzi, Juan Miguel Zarandona, Toni Dorca, Isabel Pascua Febles, M. ${ }^{a}$ Isabel García Bolta, Marie-Claire Durand Guiziou, Lisa Nalbone 


\section{COLECCIÓN}

\section{TIBÓN: ESTUDIOS TRADUCTOLÓGICOS, N. 2}

TRADUCCIÓN y recepción universal de Benito Pérez Galdós : cien ańos después (19202020) / Juan Miguel Zarandona Fernández (Coord.) ; Liebe Behiels ... [et al.]. -- Las Palmas de Gran Canaria : Universidad de Las Palmas de Gran Canaria, Servicio de Publicaciones y Difusión Científica, 2020

1 archivo PDF (232 p).- (Tibón: Estudios Traductológicos; 2)

ISBN 978-84-9042-378-3

1. Traducción e interpretación 2. Pérez Galdós, Benito (1843-1920) - Traducciones 3. Pérez Galdós, Benito (1843-1920) - Crítica e interpretación I. Zarandona Fernández, Juan Miguel, coord. II.Behiels, Lieve, coaut. III. Universidad de Las Palmas de Gran Canaria, ed. IV. Serie

82.03:821.134.2PérezGaldós, Benito

Directora de la Colección: Isabel Pascua Febles

(C) del texto: los autores

(C) de La montaña de San Juan de la cubierta: Héctor Vera López

(C) de la edición:

Universidad de las Palmas de Gran Canaria

Servicio de Publicaciones y Difusión Científica

$1^{\text {a }}$ edición. Las Palmas de Gran Canaria, 2020

www.spdc.ulpgc.es

serpubli@ulpgc.es

ISBN: 978-84-9042-378-3

DOI: https://doi.org/10.20420/1614.2020.447

THEMA: CFP, DSBF, DSBH, DSK, 2ADS

Maquetación y diseño:

Servicio de Publicaciones y Difusión Científica de la ULPGC

Reservados todos los derechos. Ni la totalidad ni parte de este libro puede reproducirse o transmitirse por ningún procedimiento electrónico o mecánico, incluyendo fotocopia, grabación magnética o cualquier almacenamiento de información y sistema de recuperación, sin permiso escrito de la Editorial. 


\section{ÍNDICE}

PRÓLOGO

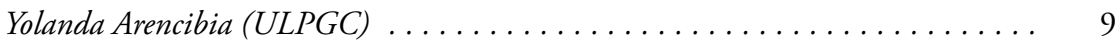

INTRODUCCIÓN

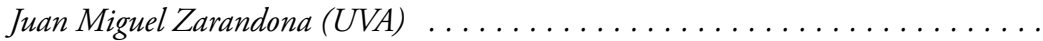

I. Las traducciones de Pérez Galdós en el ámbito de la

lengua neerlandesa

Lieve Behiels (KU Leuven) . . . . . . . . . . . . . . . . . . . . . . . 17

II. Estudio de la correspondencia entre Pérez Galdós y sus

traductores alemanes

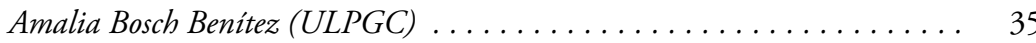

III. Visibilidad frente a invisibilidad del traductor en las obras de

Pérez Galdós al alemán

Pilar Martino Alba (URJC)

IV. La obra de Pérez Galdós en las traducciones italianas

Assunta Polizzi (UNIPA) . . . . . . . . . . . . . . . . . . . . . .

V. Los retos sociales, históricos y culturales de las dos traducciones

inglesas de la novela Tormento de Benito Pérez Galdós (1884),

Torment (1952) e Infierno (1998)

Juan Miguel Zarandona (UVA) .

VI. Reivindicación y apropiación de un género galdosiano:

los Episodios de una guerra interminable de Almudena Grandes

Toni Dorca (Macalester)

VII. Bibliografía de las traducciones de Benito Pérez Galdós

Isabel Pascua Febles (ULPGC) y M. ${ }^{a}$ Isabel García Bolta

VIII. Consideraciones sobre la traducción al francés del cuento inédito

Rompecabezas de Benito Pérez Galdós

Marie-Claire Durand Guiziou (ULPGC) 
Índice

IX. Consideraciones sobre la traducción al inglés del cuento inédito

Rompecabezas de Benito Pérez Galdós

Lisa Nalbone $(U C F)$. . . . . . . . . . . . . . . . . . . . . . . . . . . . . 199

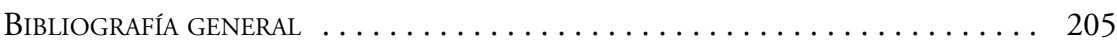

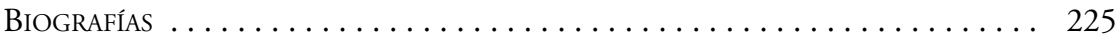




\section{PRÓLOGO}

\section{GALDÓS Y LA INVESTIGACIÓN EN LA UNIVERSIDAD DE LAS PALMAS DE GRAN CANARIA}

Los responsables de la «Colección Tibón: Estudios Traductológicos» han decidido dedicar su volumen $n .^{\circ} 2$ a nuestro novelista Pérez Galdós: Traducción y recepción universal de Benito Pérez Galdós: cien años después (1920-2020), sumándose así a la conmemoración del primer centenario de su muerte. Los responsables de la colección, he dicho; nombres propios en primera fila, y la Institución que los acoge en la base y en el fondo: la Universidad de Las Palmas de Gran Canaria y su Facultad de Traducción: Rafael Robaina, rector, e Isabel Pascua, profesora de dicha Facultad y directora editorial de esta colección.

Nada más apropiado, más justo y más lógico es que nuestra Universidad y sus investigadores respondan a la efeméride galdosiana, aunque ¡ay!, permanezca muda, precisamente, la Facultad de Filología.

En estos días en que toda España responde a la llamada del Galdós 2020, en que Santander recuerda que fue la ciudad «elegida» por don Benito para el trabajo tranquilo, el ocio y la distención, y en que Madrid pregona con orgullo el título de «la ciudad de Galdos», nosotros los vecinos de don Benito, los grancanarios, podemos sonreír con orgullo legítimo convencidos de que Galdós es universal, al igual que por compartir su legado, pero de que nadie como nuestra tierra demostró el amor al hijo en las horas de la desgracia y el infortunio. No podemos olvidar (es fácil y cómoda la mala memoria) que cuando la personalidad literaria de Galdós soportaba reproches y hasta insultos, cuando se le leía de manera sesgada en aquellas primeras décadas de un régimen político que no podía contarlo entre los suyos, nuestro Cabildo, la más propia de nuestras instituciones, afrontó la empresa de abrirle un Museo en su casa natal; un Museo para conservar su legado, para mimarlo y para ofrecerlo a todo el que quisiera acercarse al mundo del novelista para entenderlo mejor y así, apreciarlo como el gran Galdós merece. Para perennizar su memoria. De nuevo, nombres propios en primera fila y una institución bien gobernada en su base. Fueron muchos los protagonistas; anotemos ahora solo los más sobresalientes: Matías Vega Guerra y Alfonso Armas Ayala.

¿Y Galdós en nuestra Universidad de Las Palmas de Gran Canaria? Antes de que nuestra universidad tuviera existencia oficial, Alfonso Armas había logrado hacer de la CasaMuseo el Centro de Investigación internacional soñado, mediante los Congresos Internacionales de Estudios Galdosianos, que nacieron para perdurar en la edición de 1971, la primera, que reunió en nuestra ciudad cincuenta ponentes y casi cien congresistas venidos de todas partes del mundo "desde Rumanía a los Estados Unidos de Norteamérica», destacaba Armas en la Introducción a la publicación de esa primer Acta. Se apoyaba científicamente en catedráticos de otras universidades (con su prestigio, su apoyo) y en 
la Universidad Internacional Pérez Galdós, que dependía en teoría de la Universidad de La Laguna.

Al alcanzar los congresos galdosianos la edición IV (1990) ya Galdós se había «convertido en nombre propio ineludible dentro de la bibliografía española» y ese Congreso necesitó dos tomos de actas para sus casi ciento cincuenta ponencias. Por otra parte, la Universidad Internacional Pérez Galdós había muerto y la parte humanística de nuestra Universidad tenía apenas un año de vida además de una experiencia acumulada, paso a paso, desde 1982 en el Colegio Universitario de Las Palmas. Alfonso Armas veía clara la necesidad de que la investigación galdosiana que impulsaba y acogía el Cabildo de Gran Canaria a través de la Casa-Museo Pérez Galdós tuviera el apoyo, la solvencia, el refrendo y el impulso que necesitaba en la Universidad de Las Palmas de Gran Canaria, que se desarrollaba con optimismo y amor, energía y mucho esfuerzo. Confiaba en la Facultad de Filología recién nacida, y veía en ella el marco apropiado para la creación de la Cátedra Pérez Galdós, que él concebía como un espacio de apoyo para las actividades de la Casa-Museo. Soñaba Armas con un espacio común de trabajo, sólido, con medios y personalidad propias, con un director ligado exclusivamente a ella; casi como nuestros actuales Institutos. Ese director sońado debía tener una sede, un despacho dotado de personal, unos medios propios, una gratificación, un estatus... No había otro director que él. No sólo era el mejor, sino que lo merecía ampliamente. Pero habían cambiado mucho las cosas. La Universidad era una Institución ligada a estamentos y a reglamentos en los que él no tenía espacio porque estaba jubilado de su cátedra de Enseñanza Media y nuestra Universidad tenía un gran peso de lo técnico y lo científico en una sociedad en que apuntaba el desprecio a las Humanidades. En resumen, por ningún concepto esa Cátedra no podía ser cómo él se imaginaba. Y a nadie le interesa mucho, la verdad. Por si eso fuera poco, la salud y el equilibrio de don Alfonso había ido deteriorándose con rapidez.

Nació sin embargo, la Cátedra Pérez Galdós con más convencimiento por parte del Cabildo que intuía ella un apoyo intelectual necesario, que por la Universidad que (opinión propia) la creó para tranquilizar a don Alfonso Armas. Y pudo nacer cuando la Facultad de Filología tuvo una primera catedrática, precisamente, una investigadora galdosiana en quien don Alfonso, o lo que quedaba de él entonces, confiaba. Fue el 21 de abril de 1995. El Rector Rubio Royo y el entonces Presidente del Cabildo don Pedro Lezcano firmaron el convenio de la Cátedra Pérez Galdós, «una zona de coincidencia» entre los intereses académicos de la Universidad y «la responsabilidad del Cabildo en cuanto al legado galdosiano». Parecía un día de fiesta. Se inauguró casi con solemnidad y la prensa local la señaló con buen augurio. Pero solo eran voladores. La financiación, el estatus, el organigrama... Y así con todo entusiasmo y entrega, la Cátedra empezó su andadura en 1995. La directora de la Cátedra (que a la sazón era decana de la Facultad de Filología) se sentía muy bien pagada con sus retribuciones normales de profesora y sin aliciente extra de ningún tipo; tampoco una reducción de su carga docente. Tuvo la Cátedra el apoyo verbal de la Facultad de Filología, pero no el del Departamento correspondiente. Sin embargo, comenzó a trabajar de inmediato, al alimón la directora recién nombrada y la de la Casa-Museo, a la sazón Rosa M. Quintana, quienes compartían entusiasmo, capacidad de trabajo y cierta habilidad para conseguir financiaciones. Como mero apunte, señalemos que en ese 1995 la Casa-Museo pudo acoger tres cursos universitarios 
de posgrado (entre junio y noviembre), la directora de la Cátedra asistió a una reunión de asesoramiento galdosiano en la Universidad de Sheffield, y ediciones del Cabildo pudo culminar la edición de una novela galdosiana trabajada en un seminario de doctorado de la Universidad.

Así siguieron las cosas en el adelante inmediato, siempre con la presencia y el apoyo moral de la Universidad en las reuniones públicas. Empeoraron durante el rectorado de don Manuel Lobo, y mejoraron mucho en el de don José Regidor, en el que se renovaron los Estatutos con el Cabildo y se reafirmó la presencia de la Cátedra en imagen y en el alojamiento científico, que pudo ser en el recién creado Iatext (Instituto Universitario de Análisis y Aplicaciones textuales). Hoy tiene el aprecio del Rector Robaina y algunos proyectos en estudio. Diríamos que nada ha avanzado administrativamente desde 1995. ¿Por qué iban a cambiar las cosas si las Humanidades y su investigación apenas interesan? Paralelamente, también han cambiado los objetivos del Cabildo de Gran Canaria respecto a la Casa-Museo que, adaptándose a «lo que requiera la sociedad», se encaminan a lograr «un museo vivo (...) en el que el ciudadano se familiarice con Galdós (...) incrementando el número de visitantes» y eliminar el posible elitismo intelectual, idea del pasado «que puede que siga vigente entre algunos reductos de la sociedad (...) pese al trabajo de los museos para cambiarla» (entrevista a la directora del Museo, Canarias 7, 7 de septiembre de 2017).

Son en efecto, nuevos tiempos en que la Cátedra Pérez Galdós no tiene sentido. En realidad, no existió nunca; solo existieron voluntades humanísticas que trabajaron por la supervivencia de un mundo de Humanismo que en nuestro panorama no interesa a nadie. ¿A casi nadie? Mejor así.

Pero el que la Cátedra Pérez Galdós no tenga futuro, no quiere decir que no lo tenga el galdosismo. Mucho han cambiado los investigadores que pueblan hoy nuestros Congresos; que siguen viniendo de muy lejos porque Galdós es universal, pero cuya mayoría viene de las Universidades españolas en donde la investigación galdosiana se ha multiplicado abriéndose a nuevas vías, nuevos retos. Galdós es inmenso, y su investigación también lo es.

Y aquí una prueba, en este número de Tibón que ha congregado a un número importante de investigadores del mundo de la traducción, esa ciencia imparable que enriquece a los autores privilegiados. Porque si traducir es verter a otro idioma, también es enriquecer la creación individual ańadiendo a su obra el rayo de luz de otra lengua, que es siempre una visión, distinta pero no traicionera. Es una vertiente de la imitatio clásica. ¿Y qué otra cosa es la literatura que una imitación de la realidad desde una subjetividad tocada por el genio?

Cierro estas páginas como las empecé. La Universidad de Las Palmas de Gran Canaria, en su conjunto, debe estar agradecida a quienes concibieron este número de TIBÓN reuniendo a tantas intelectualidades diferentes. Por mi parte, muchas gracias por haberme permitido estas palabras iniciales y mucha suerte en el futuro de su carrera científica.

Yolanda Arencibia

Directora de la Cátedra Pérez Galdós 



\section{INTRODUCCIÓN}

Benito Pérez Galdós, ilustre y querido hijo de Las Palmas de Gran Canaria, donde nació en 1843, nos dejó el 4 de enero de 1920 en su ciudad de adopción desde su primera juventud, Madrid. Su semblante profundo y taciturno, su serenidad de ánimo, su implacable poder de observación, su mansa mirada de comprensión hacia los débiles y desafortunados, su elegante independencia, la facilidad de su pluma, todo ello y mucho más han acompañado a los españoles desde entonces. Y lo ha hecho tanto en el recuerdo de su persona como en la lectura y análisis de sus obras, reproducidas y estudiadas estas una y mil veces en gran número de formatos, desde las ediciones eruditas hasta la adaptaciones más propias de la cultura popular, el cine o el cómic.

Una multitud salió a acompañar sus restos mortales - un todo Madrid- y a despedir a quien tanto le había retratado en palabras, desde la admiración, pero seguramente más desde el agradecimiento, el 5 de enero de 1920, vestidos de frío e invierno, como sus sentimientos más íntimos. La mítica foto que retrató el cortejo fúnebre entre el palacio de Linares y el de Correos, camino de la Puerta de Alcalá, así lo ha dejado atestiguado para siempre.

Y el fenómeno de amable conexión del escritor con sus lectores no solo no ha cesado nunca, sino que, además, ha conocido un auge explosivo en este año de 2020, con motivo del centenario de su partida, donde un nuevo cortejo innumerable de homenajes, exposiciones, reportajes, reposiciones cinematográficas, dosieres, reediciones, estudios, biografías, comentarios varios, congresos y jornadas, galerías fotográficas, etc. ${ }^{1}$ Don Benito ha terminado de cruzar el umbral de los inmortales en este año de 2020. Gracias, maestro.

Este volumen, que hemos titulado: Traducción y recepción universal de Benito Pérez Galdós: cien años después (1920-2020), se encuadra dentro de los límites del ya citado fenómeno. A don Benito se le puede homenajear desde muchos ángulos o puntos de vista: el nuestro ha sido producir un volumen de capítulos de investigación, escritos por traductólogos o expertos galdosianos, que posean en común el hecho de prestar atención a la realidad de la intertextualidad o aquel rasgo de los textos según el cual dichos textos, para ser dignos de dicho nombre, han de albergar dentro de sí mismos el rastro o las huellas de otros textos previos hasta llegar a crear una cadena infinita de herencias textuales. No hay fenómeno intertextual más poderoso que la traducción, como pueden también serlo la adaptación o la imitación, por ejemplo.

1 Entre las propuestas más atractivas y originales de este año galdosiano cabe enfatizar el volumen titulado: Galdós responde. Desde los siglos XIX / XX a preguntas del siglo XXI, del escritor grancanario Juan Carlos de Sancho, quien imagina unos creativos diálogos entre él mismo y don Benito, donde el segundo comenta realidades de nuestro tiempo desde la perspectiva de su pensamiento y visión propia de los siglos en los que vivió según se atesora en sus obras. 
Por otra parte, en 1992, se publicó un volumen ya clásico dentro del ámbito de los estudios literarios y los estudios de traducción: Translation, Rewriting, and the Manipulation of Literary Fame, del admirado y añorado André Lefevere. La recepción, vigencia y permanencia de los textos dependen de su reescritura. ¿Quién lee a Homero hoy en día directamente en su lengua griega arcaica? Muy pocos. Lo que se lee son sus reescrituras, a saber, traducciones, adaptaciones (para el público juvenil, para la gran pantalla, etc.), modernizaciones, crítica literaria, resúmenes, reseñas, comentarios, imitaciones, textos inspirados, continuaciones, pastiches, etc. Una reciente aportación bibliográfica de otro gran teórico de la Traductología, Edwin Gentzler, la titulada: Translation and Rewriting in the Age of Post-Translation Studies (2017), insiste en la vía de debate abierta por Lefevere al volver a asociar, desde el título, traducción y reescritura, para proponer un nuevo enfoque de la disciplina, los pos estudios de traducción, que tenga en cuenta todas las posibles variantes textuales que un texto puede originar.

Con estas ideas, podemos aclarar que en este volumen hemos querido atender a la recepción clásica de toda la obra literaria de Pérez Galdós mediante la traducción, pero sin excluir, sino todo lo contrario, propuestas que se ocupen de otros fenómenos de recepción y reescritura de las páginas del grancanario, y todo ello en consonancia con los tiempos y la teoría y práctica contemporánea de la traducción.

Es queja casi unánime de la crítica y de la bibliografía sobre Benito Pérez Galdós que nuestro autor no ha alcanzado el lugar que le correspondería en la República Universal de la Letras por no haber conocido un número suficiente de traducciones, carencia que incluso hoy en día todavía se arrastraría y que lo separaría de sus homólogos: Dickens, Flaubert, Balzac o Tolstói, entre otros. ${ }^{2}$ En consecuencia, porque en gran medida estamos de acuerdo con esta creencia, porque creemos que el futuro no está nunca escrito (si hiciera falta traducir más, traduzcamos), y porque se trata de una realidad no bien medida, lo que la convierte en un campo de investigación novedoso que todavía requiere atención, por todo esto hemos defendido este libro y este título, Traducción y recepción universal de Benito Pérez Galdós: cien años después (1920-2020), que reúne estudios galdosianos y estudios de traducción dentro del enfoque antes comentado.

Los lectores de este segundo volumen de la colección Tibón de la Universidad de Las Palmas de Gran Canaria, con la colaboración de la Casa-Museo Pérez Galdós, podrán encontrar un total de diez capítulos, que pueden agruparse de la manera siguiente. Los primeros cuatro capítulos tienen en común el hecho de presentar los resultados finales, fruto de rastreos muy completos, de la recepción, mediante la traducción de la obra, de Galdós en los entornos neerlandeses, Flandes (Bélgica) y Países Bajos, alemán e italiano.

Las cuatro autoras abordan un trabajo empírico de campo tan necesario como minucioso en los datos que se descubren o reúnen. Trazan un buen ejemplo a seguir a la

2 La concesión del premio Nobel tal vez hubiera puesto remedio a esta ausencia de traducciones. Sin embargo, no corresponde a esta introducción dirimir las polémicas causas de esta no concesión. 
hora de aplicar sus métodos a todos los otros ámbitos posibles de recepción de los títulos galdosianos. El capítulo quinto aborda un estudio de caso más limitado, es decir, una comparación entre las dos traducciones británicas del siglo XX de la novela contemporánea Tormento (1884).

El capítulo sexto forma una unidad consigo mismo. Nos encontramos ante una original propuesta del estudio de las novelas más exitosas de la escritora española de actualidad Almudena Grandes con la vista puesta en los Episodios nacionales de Benito Pérez Galdós, su modelo e inspiración, lo que constituye todo un juego literario localizable entre la adaptación y la apropiación.

Por su parte, el capítulo séptimo recoge una aproximación muy completa a todas las traducciones que en la historia han sido de las publicaciones literarias de don Benito, desde aquellas vertidas a las lenguas de cultura principales de Occidente (francés, inglés, alemán, italiano, portugués, neerlandés, etc.), o las lenguas más exóticas y alejadas que podamos recordar: japonés, chino, árabe, ruso, polaco, etc. El resultado que se ofrece puede calificarse de pionero sin lugar a dudas.

Los capítulos octavo y noveno pueden de nuevo agruparse al ofrecer a los seguidores presentes y futuros de Galdós la traducción de uno de sus cuentos, «Rompecabezas», al francés y al inglés, lenguas en las que todavía se hallaba, inexplicablemente, inédito. Aparte de ser cada uno de ellos un pequeño gran hito en la historia de las traducciones de textos de Galdós a otras lenguas, muestran de nuevo un camino a seguir. Todavía hay gran necesidad de traducir a don Benito, incluso a lenguas principales o mayoritarias, ya que en ninguna es posible encontrar su obra completa en traducción.

Finalmente, el capítulo décimo recoge la bibliografía de todo el volumen reunida para su mejor consulta.

Todos los implicados en la confección de este volumen creemos que este volumen constituye solo un primer paso que debería tener continuación. Es aún necesario trazar definitivamente el mapa de las traducciones de Pérez Galdós a otras lenguas; es aún necesario investigar muchas de estas traducciones en profundidad; es aún necesario promover la traducción de Galdós a muchas lenguas, por no decir a todas. Nuevos monográficos, una colección especializada o la organización de encuentros científicos especializados en esta temática han de ser las herramientas imprescindibles para abordar esta tarea y conseguir resultados. 



\title{
CAPÍTULO I
}

\section{Las traducciones de Pérez Galdós en el ámbito de la lengua neerlandesa}

\author{
Lieve Behiels
}

KU Leuven

\section{INTRODUCCIÓN}

Las traducciones de Galdós al neerlandés se distribuyen básicamente en tres etapas. La primera corresponde al periodo entre 1872 y 1903, en vida del autor. Entre 1959 y 1979 se produjeron tres traducciones más. Finalmente, entre 1998 y 2004 se publicaron seis novelas de Galdós en traducción neerlandesa, disponibles también en edición electrónica a partir de 2012. En esta contribución seguiremos, pues, el orden cronológico. Consideramos el fenómeno de la traducción en un sentido amplio, con lo cual integramos también unos resúmenes comentados, unos folletines y una adaptación teatral. Teniendo en cuenta las dimensiones de este artículo, no será posible realizar un análisis comparativo entre los textos fuente y los textos meta. Nos dedicaremos a un estudio lo más detallado posible de los factores externos del proceso de traducción y de recepción en el contexto neerlandés: quiénes fueron los traductores, qué editoriales se interesaron por la obra galdosiana, cómo fueron recibidas las traducciones por la crítica periodística y literaria, en qué medios se publicaron reseñas, quiénes fueron los críticos literarios. Es evidente que nuestros resultados, sobre todo por lo que se refiere a las traducciones producidas en el siglo XIX, no pueden ser más que provisionales, porque no se puede excluir que en un futuro se pueda tener acceso a un mayor número de fuentes accesibles en la red, ya que en Holanda está en marcha un programa ambicioso de digitalización de la prensa histórica.

\section{TRADUCCIONES PUbliCADAS EN VIDA DE GALDÓS}

\subsection{Los resúmenes comentados de P. N. Muller}

Las primeras menciones de Galdós en una revista cultural holandesa datan de 1872. El comerciante y publicista P. N. Muller (Pieter Nicolaas Muller, 1821-1908) ${ }^{1}$ publica en

1 Para el perfil de este autor véase https://www.dbnl.org/auteurs/auteur.php?id=mull011. 
la revista De Gids un artículo titulado «De gouden fontein» («La fuente de oro»). La asociación con la primera novela galdosiana se realiza gracias al subtítulo: «La Fontana de Oro por Don Benito Perez Galdos. Madrid, 1871». Después de una introducción de una decena de páginas que esboza el contexto histórico de la primera novela que Galdós publicó, sigue un extenso resumen de veintisiete páginas, terminado por una conclusión histórico-moralizadora: el único camino hacia la libertad es la unidad y solo tiene sentido para los presentes enorgullecerse de las glorias pasadas si demuestran la capacidad de elevarse a la misma altura y mantenerse allí (Muller 1872: 517). Del mismo autor salen también en De Gids, la revista cultural y literaria de más larga vida en lengua neerlandesa (de 1837 hasta hoy) dos contribuciones sumando unas cincuenta páginas sobre las primeras series de los Episodios nacionales: «Españolismo of Spanje bovenal» («Españolismo o España por encima de todo»), ${ }^{2}$ en 1877 (Muller 1877a, Muller 1877b). Aquí también encontramos, a modo de introducción, un esbozo de la situación política en España. El autor estima que antes de oponerse a todo lo que venga de fuera, los españoles deberían tender hacia la unidad nacional, y Galdós contribuye a este fin gracias a su obra. El novelista recuerda a sus compatriotas, en forma de novela, que se liberaron de la opresión francesa en la guerra de la Independencia gracias a su unidad (Muller 1877a: 509). Muller ha emprendido la tarea de dar a conocer la obra de Galdós a sus compatriotas porque los traductores no se interesan por la literatura del sur de Europa:

\begin{tabular}{|c|c|}
\hline $\begin{array}{l}\text { «De eenzijdigheid onzer vertalers en vertaalsters } \\
\text { daarenboven, die alle zóó gretig aanvallen op } \\
\text { elken nieuwen Engelschen roman dat daarvan } \\
\text { meer dan een zelfs dubbel vertolkt wordt, laat } \\
\text { ongelukkig de nieuwe Spaansche en Italiaansche } \\
\text { romans ongebruikt liggen» (Muller 1877a: 509). }\end{array}$ & $\begin{array}{l}\text { Además, la limitación de nuestros traducto- } \\
\text { res y traductoras, que se lanzan todos con } \\
\text { tanta avidez sobre cualquier novela inglesa } \\
\text { nueva que más de una se traduce doble- } \\
\text { mente, lamentablemente deja sin tocar las } \\
\text { novelas españolas e italianas nuevas. }\end{array}$ \\
\hline
\end{tabular}

Declara sentir más admiración por la nobleza de las ideas del escritor que por sus méritos literarios y destaca la rapidez de su producción. Después de quince páginas de introducción, sigue una síntesis de varios episodios, culminando con la de Zaragoza (Muller 1877b: 503-519).

En 1879, P. N. Muller firma, siempre en la misma revista, un artículo titulado «Gloria», subtitulado «Pérez Galdós. Madrid». Galdós publicó su novela en 1876. Aquí falta cualquier contextualización previa al extenso resumen. En un párrafo de conclusión, Muller observa que, de modo independiente, tres autores de talento escogen como tema una convicción religiosa potente: Pérez Galdós en Madrid con Gloria, George Eliot en Londres con Daniel Deronda, y Louiza von François en Berlín con Natur und Gnade. Se pregunta si se trata de una mera casualidad o más bien de la necesidad de una fe fuerte que busca acceder a los corazones de los pueblos (Muller 1879: 252).

Gracias a las contribuciones de P. N. Muller, el lector culto holandés podía tener una impresión detallada de algunas de las primeras novelas galdosianas.

2 Las traducciones de citas y títulos son nuestras, salvo indicación de lo contrario. 


\subsection{Las traducciones de las novelas de tesis}

En otoño de 1883 se publica bajo el título de Dona Perfecta, la traducción de Doña Perfecta. En la portada reza como nombre del traductor la abreviatura M. A. de G..., identificada como Maria Anna de Goeje (Pérez Galdós 1876/1883). ${ }^{3}$ Se trata de una de las primeras traducciones de esta novela, puesto que solo la versión rusa (1882) es anterior, mientras en Estados Unidos se publicaron dos traducciones al inglés en el mismo año 1883 (García Bolta 1993: 47). Es poco probable que la traductora haya podido acceder a estos libros y podemos asumir que se trata de una traducción directa, tal como figura en los anuncios en la prensa de la época, que mencionan una versión «uit het Spaansch», «del español» (s. n. 1883). Maria Anna de Goeije (1850-1927) era una reputada profesora de lengua neerlandesa del instituto femenino público de Róterdam. No hemos encontrado datos sobre su adquisición de lenguas extranjeras. Previamente, en 1879, había traducido la novela italiana, Tizio Caio Sempronio de Anton Giulio Barrili (1877), bajo la supervisión de H. Mulder, como queda especificado en la portada de este libro. Esta precisión puede llevar a pensar que se trataba de una traductora inexperta que necesitaba ser guiada. Su mayor éxito como traductora lo consiguió con una serie de tres libros alemanes dirigidos a niñas, titulados en el original Der Trotzkopf(1885), de Emmy von Rhoden, y en traducción Stijfkopje (1893-1896); la traducción de esta trilogía siguió imprimiéndose hasta los ańos treinta del siglo XX. Maria Anna vivió junto a su hermana Reinoudina, muy conocida bajo el seudónimo de «Agatha» como autora de literatura infantil y también traductora. La traducción salió en la editorial Brill de Leiden, especializada en la actualidad en publicaciones científicas internacionales, una empresa prestigiosa que lleva colaborando con la universidad de dicha ciudad desde el siglo XVII y que en el XIX también tenía un fondo literario.

Hemos localizado una reseña de esta traducción, de la mano de David François van Heyst, publicada en 1885 en una revista mensual miscelánea ilustrada que contenía poesías, cuentos y reseñas, Het Leeskabinet. La reseña contiene un resumen y un comentario elogioso de la novela y enfatiza la oposición entre Pepe Rey, el hombre de ciencia, oriundo de la capital, cosmopolita y abierto hacia lo nuevo y los habitantes de Orbajosa, orgullosos de sus tradiciones sociales y religiosas y reacios a los cambios, que el autor esboza con mano maestra. Heyst interpreta la doblez y la hipocresía de Perfecta y del canónigo como típicas de los países del sur, mientras Pepe Rey no resulta lo suficientemente español: podría ser de todos los lugares, pero no de España. El crítico estima que el protagonista recibe su merecido, debido a la brutalidad con la que se enfrenta a su familia de Orbajosa. Elogia la claridad, la fluidez y la excelencia de la traducción, que debido al nombre abreviado no sabe si atribuirla a un traductor o a una traductora (Heyst 1885).

De la traducción neerlandesa de Doña Perfecta se ha conservado una copia en la Koninklijke Bibliotheek de Holanda (760 D 22) y otra en la Casa-Museo Pérez Galdós (Sig. ${ }^{2}$ X-329, Nuez 1990 n $^{\circ} 1712$ ), pero de las que mencionaremos a continuación parece no quedar ninguna. En mayo de 1890 se anuncia en la prensa la publicación de la traducción de Marianela (s. n. 1890a). El subtítulo reza «uit het Spaansch vertaald door Una» («traducido del español por Una»), lo que parece apuntar a la labor de una traductora que debió

3 La Casa-Museo Pérez Galdós posee una tarjeta de la traductora fechada en 1903 (Nuez 1990: 329). 
preferir el anonimato. El libro fue editado por A. H. Adriani de Leiden. Esta modesta editorial sacó a la luz tesis doctorales, publicaciones ocasionales, libros para la juventud y varias obras de Galdós (Dongelmans 2008: 5). La revista De Tijdspiegel publicó una reseńa cuyo autor la firma escuetamente con la inicial $\mathrm{H}$. Al reseñador, que se limita a apuntar la temática social de la novela, le llama la atención que en una novela emanada de un país católico romano, se encuentre una crítica explícita de las «buenas obras». Recomienda su lectura y elogia la traducción vertida en «buen holandés» (H. 1890). También apareció una reseña, esta vez anónima, de la novela en la sección dedicada a las reseñas de la revista cultural y literaria católica De Dietsche Warande, publicada en La Haya (Holanda) y en Gante (Bélgica). El crítico elogia los sentimientos tiernos, el refinamiento sicológico y la belleza lírica de la novela y, tratándose de un libro "puro», recomienda su lectura (s. n. 1890b). Aunque no tenemos conocimiento de ningún ejemplar de esta traducción, conviene señalar que entre febrero y mayo de 1905 el folletín de Tubantia, un periódico local de la región de Twente en el este de Holanda, correspondía a De blinde en zijne gids. Spaansche novelle van Perez Goldós [sic] (Pérez Galdós 1905). Salió en dieciocho episodios y es una versión fuertemente resumida de la obra de Galdós, posiblemente basada en la traducción de 1890 .

La recepción positiva de Marianela puede haber contribuido a que, en 1891, el editor Adriani dirigiera una petición a la comisión para los derechos de traducción para traducir La familia de León Roch. El mismo año se encuentran en la prensa anuncios comerciales de la traducción titulada Leon Roch en familie, firmada por P. du Buy (s. n. 1891). Tampoco ha sido posible localizar una copia de este libro. Du Buy fue director de un internado en Haarlem y se anunció como profesor de las lenguas francesa, inglesa, alemana, italiana, sueca y danesa (Buy 1880). En 1879 tradujo un libro de un jesuita italiano expulsado de la orden por sus opiniones disidentes acerca de la relación entre la Iglesia y la sociedad moderna (Curci 1878/1879). También tradujo cuentos del italiano y del danés para la revista Het Leeskabinet. Como su antecesora Marianela, esta novela fue reseñada positivamente en la revista De Tijdspiegel, por el mismo crítico que firma con la abreviatura $\mathrm{H}$. En la reseña se oponen el catolicismo de relumbrón de la familia política de León y el fanatismo religioso de su esposa a los auténticos valores religiosos y morales del protagonista.

\subsection{La traducción de Electra}

En 1901 se traduce la obra de Galdós que más se discute en la prensa holandesa, antes por sus repercusiones políticas que por su valor literario: el drama Electra. A partir del dos de febrero se suceden los artículos relativos al escándalo provocado por la obra, el éxito que obtiene en provincias y en el extranjero, las tentativas por parte de la Iglesia para prohibir la obra y un largo etcétera. ${ }^{4} \mathrm{Y}$ ya en febrero, A. H. Adriani pide los derechos para traducir la obra. El estreno holandés estaba previsto para el domingo siete de abril, a cargo de la compañía del teatro Tivoli de Róterdam, bajo la dirección de Johan Mulder. Algunas organizaciones católicas habían enviado una carta al teniente de alcalde de la

4 Los ecos de Electra en la prensa holandesa son tan numerosos y variados que se merecerían un estudio separado. 
ciudad a fin de conseguir la prohibición de la obra. Este envió a un oficial de policía católico a un ensayo, y el policía no vio ningún motivo de escándalo. En un artículo del periódico Algemeen Handelsblad se apuntaba a la supuesta mutilación del drama de Galdós y a la transformación de la figura de un jesuita en un señor bien trajeado. Al día siguiente se publica en el mismo periódico una carta de Adèle J. Godoy, quien se manifiesta como la traductora de la obra, afirma que en su traducción no se ha suprimido ninguna escena y precisa que Salvador Pantoja no es un sacerdote sino un fanático religioso laico (Godoy 1901a).

Adèle Godoy (1863-1918) nació en América Latina, llegó a Holanda, aprendió el neerlandés y se hizo actriz de teatro (Historisch Antiquariaat A. G. van der Steur 1992: 1155). Posteriormente ejerció como profesora de español. Además de Electra tradujo El sombrero de tres picos de Alarcón (De steek, 1907) y publicó materiales didácticos para la enseñanza del español. Después de unas representaciones en Róterdam, la obra pasa a Ámsterdam, donde se estrena el 17 de abril. El 18, el crítico Giovanni escribe una reseńa algo irónica en la que pone de relieve la total ausencia, a su juicio, de expresiones anticlericales en la obra en la que supuestamente solo se ha suprimido una frase (Giovanni 1901). A continuación, el 20 de abril, aparece una carta de P. W. de Koning, poeta, autor dramático, traductor y jurista. Tiene delante el original español y la comparación del texto galdosiano con lo que recuerda haber escuchado en el teatro le lleva a concluir que las modificaciones son numerosas y que la figura de Pantoja tal como se representó no es más que una caricatura de la ideada por Galdós (Koning 1901a). La traductora publica una réplica a esta carta el 23 de abril, en la que pide que P. W. de Koning le indique los cambios que hizo en la traducción e insiste en que se limitó a las modificaciones imprescindibles. Remite a los lectores interesados en la comparación a un artículo de Ernest Rivaud en la revista L'Illustration del 23 de marzo, que comprende citas de la obra galdosiana (Godoy 1901b). P. W. de Koning contesta el 27 de abril. En general, estima que se ha traducido con demasiado desenfado y da ejemplos de lo que ha escuchado. En cuanto al carácter de Pantoja, se ha puesto de relieve su carácter tiránico, pero no su sed de poder y su orgullo espirituales (Koning 1901b). El 1 de mayo, la traductora hace uso de un último turno de réplica. Adèle Godoy no está convencida por los ejemplos de Koning, ya que estima que la traducción teatral necesita alguna libertad y considera que se ha mantenido fiel a la intención del autor. En su opinión, la clave del tumulto causado por la obra en España no está únicamente en el carácter de Pantoja, sino que cualquier alusión a la libertad de conciencia basta en España para levantar los ánimos de los espectadores de un modo inimaginable en Holanda (Godoy 1901c). Con esta tercera carta, la redacción del periódico decide cerrar el debate.

El 26 de abril se anuncia la publicación de la traducción por Adèle Godoy en forma de libro en una revista especializada para libreros (s. n. 1901b). Ahora bien, en la portada del libro aparece «vertaald door S.» («traducido por S.») (Pérez Galdós 1901/1901). Y el 31 de abril, la misma revista publica una rectificación, diciendo que la traducción «fiel a la palabra» («woordgetrouw») no es la de Godoy, que se encargó de la versión para el escenario (s. n. 1901c). Habría, pues, dos traducciones de Electra al neerlandés, una «teatral» realizada por la profesora de español familiarizada con las tablas que defiende públicamente sus opciones y otra anónima. 
Localizamos varias reseñas de la traducción impresa. El crítico anónimo de la revista cultural De Nederlandsche Spectator ofrece un resumen de la obra y observa que tiene preguntas acerca de la traducción, pero como no dispone del original, no las puede resolver, aunque estima que el espíritu del autor se ha respetado lo suficiente (s. n. 1901d). En la revista Dietsche Warande en Belfort, el crítico católico belga Jules Persyn escribió una amplia reseña que comenzaba con la confesión de que Electra era la primera obra de Galdós que había leído. Dando por descontado la poca familiaridad de sus lectores con la obra galdosiana, dedica tres páginas a la presentación biobibliográfica del autor. Destaca que con el tiempo Galdós se hizo cada vez más artista pero le reprocha la codicia y el cálculo. Como el valor artístico creciente de sus obras no dio los beneficios esperados, Galdós decidió dedicarse al teatro, con un éxito modesto, hasta el estreno de Electra. A partir de aquí cambia el tono de la reseña. Después de la presentación de los personajes y un resumen de la intriga, Persyn elogia la técnica dramática del autor, así como la configuración rica y sobria de los personajes y la profundidad y la poesía de los pensamientos. Considera que Pantoja es una gran creación. Los caracteres de Máximo y Electra también se han dibujado con esmero. Rechaza la aparición del espectro de la madre de Electra al final de la obra. Después de las reflexiones de tipo literario, siguen las ideológicas y el tono vuelve a cambiar. A primera vista no se entiende por qué el clero español se opuso con tanta fuerza a la obra, ya que los principios defendidos por Pantoja no son propiamente cristianos. Sin embargo, hay que tener en cuenta las circunstancias. En el contexto español, Persyn no duda en afirmar que Electra constituye un acto malvado ahora que Espańa vive una crisis política y social. La misión del poeta preocupado por la suerte de su pueblo debe ser aplacar los ánimos y reorientarlos hacia la fe. El crítico recuerda el caso de Adelaida Ubao que según los anticlericales había sido encerrada en un convento contra su voluntad y acusa a Galdós de haberse aprovechado de este asunto para ganar fama y dinero (Persyn 1901). La polarización ideológica en torno a la obra se ilustra además por las representaciones de la obra en Bélgica. Fue representada en Gante en noviembre de 1901 por el Multatulikring (ć́rculo Multatuli, por el nombre de uno de los escritores progresistas holandeses más populares del siglo XIX), la agrupación teatral del movimiento socialista, en la sala de fiestas del movimiento (Bruyker 1965: 39). El grupo teatral socialista De Toekomst (El Porvenir) de Bruselas la representó el 2 de marzo de 1902 en la Casa del Pueblo (s. n. 1901e).

Sobre todo en los primeros meses de 1901, pero también a lo largo de todo aquel año se pueden rastrear en la prensa holandesa numerosas referencias a Electra en el contexto de la información acerca de la situación política turbulenta en España. Los estrenos teatrales de Alma y vida (1902), El abuelo (1904), Bárbara (1905) y Casandra (1910) son objeto de breves noticias relacionadas con la actualidad cultural internacional. El nombre del autor sigue apareciendo en los periódicos holandeses en los años siguientes, pero Galdós se ha convertido más que nada en una primera figura de la política española.

En julio de 1903 la prensa anuncia la publicación de Zuster Marcela. Roman eener non (Sor Marcela. Novela de una monja) con el editor Adriani, de Leiden (Pérez Galdós 1899 / 1903). No hay ninguna novela galdosiana titulada así, pero el misterio se desvela teniendo en cuenta que en 1902 se publicó una traducción alemana de la quinta novela de la tercera serie de los Episodios nacionales, La campaña del Maestrazgo, bajo el título de Der Roman einer Nonne (Gómez Pablos 2017: 242). Los anuncios solo dicen que se 
trata de una traducción «uit het Spaansch» («del español»), sin mención ninguna del traductor. La similitud de los títulos de ambas traducciones sugiere que el interés del editor por el libro ha surgido gracias a la publicación alemana. ${ }^{5}$ No hay manera de saber si el traductor ha tenido en cuenta la versión alemana, ya que no se ha conservado ningún ejemplar de la traducción neerlandesa. ${ }^{6}$ El editor puede haber optado por crear alguna expectativa alrededor de una monja protagonista de novela porque en el ámbito neerlandés la zona del Maestrazgo no evoca ninguna asociación. De todos modos, la novela se vendió, y en 1918 hasta se encuentra en una lista de libros antimilitaristas ofrecidos por una librería (s. n. 1918). También tuvo una reseña, firmada J. H. en la revista De Tijdspiegel. El crítico comprende que lo esencial no es que uno de los personajes sea monja, lo que importa es el marco histórico. Pero no ha entendido bien este trasfondo, ya que identifica a los montañeros dirigidos por sacerdotes y monjes como los defensores de la joven reina y no como sus oponentes carlistas (J. H. 1903). El breve artículo ni recomienda ni deja de recomendar el libro, y tampoco contiene alusión alguna a la figura del autor o a otras obras suyas.

El periódico de Batavia (la capital de las Indias Orientales Neerlandesas) Bataviaasch Nieuwsblad publicó el 2 de mayo de 1905 lo que pudo haber sido el inicio de una publicación seriada en folletín de Een episode uit den Carlistenoorlog (Un episodio de la guerra carlista) con el subtítulo «Uit het Spaansch, van Péres [sic] Galdós» (Pérez Galdós 1898/1905a). Se trata del episodio nacional Zumalacárregui, como se explica en una nota al pie, y encontramos todo el primer capítulo de la novela a partir del tercer párrafo. Después de esa fecha ya no se encuentra ninguna continuación. Curiosamente, en otro periódico colonial de Surabaya, Soerabaijasch Handelsblad, se encuentra, el 29 de mayo, el mismo «episode uit den Carlistenoorlog» que también retoma el capítulo primero del episodio galdosiano. Aquí encontramos la abreviatura del nombre del traductor: E. J. B. (Pérez Galdós 1898/1905b). Ni en uno ni en otro periódico se continuó Zumalacárregui.

Al pasar los años, se hacen cada vez más escuetas las referencias a Galdós en cuanto a su obra literaria se refiere. En 1919 se proyecta en varias ciudades holandesas una película titulada Kleine stadslucht (Aire de ciudad pequeña). Se trata de una adaptación norteamericana para el cine, Beauty in Chains (1918), anunciada como una comedia dramática según Doña Perfecta de Galdós (s. n. 1919).

En enero de 1920 se publican en la prensa holandesa varias necrologías de Galdós. Una minoría alude a Fortunata y Jacinta o a los Episodios nacionales, para la mayoría el fallecido es sobre todo el autor comprometido de Electra.

\section{LAS TRADUCCIONES DE LA SEGUNDA MITAD DEL SIGLO XX}

Entre 1903 y 1959 no se publica ninguna traducción de Galdós al neerlandés. En este año sale en la colección de bolsillo Prisma, de la editorial Het Spectrum (Utrecht) una serie

5 El catálogo de la Casa-Museo Pérez Galdós también menciona una versión francesa sin año: Le roman de Soeur Marcela (Signatura X-358, Nuez 1990, n. ${ }^{\circ}$ 1731).

6 Se puede encontrar una versión en línea de Der Roman einer Nonne (https://gutenberg.spiegel. de/ buch/der-roman-einer-nonne-2740/1) que reproduce la edición de 1902. 
de cuentos españoles de los siglos XIX y XX, reunidos por Luis de Castresana y traducidos por G. Evenhuis, bajo el título de Spaanse verhalen (Cuentos españoles). Contiene el cuento galdosiano "De roman in de tram» («La novela en el tranvía»). La colección Prisma era muy popular y ponía a disposición de los lectores sobre todo literatura y ensayos traducidos, pero también diccionarios y gramáticas de lenguas clásicas y modernas. La cubierta del libro, diseñada por Eppo Doeve (una guitarra sobre un paño rojo, un toro, una casa con una joven cubierta de una mantilla detrás de una reja) orienta al comprador hacia una España rural y estereotipada, lo que no casa con buena parte de los cuentos. Están ordenados cronológicamente, siendo el primero de Pedro Antonio de Alarcón, y el último de Ana María Matute. El compilador Luis de Castresana era un «niño de la guerra» (1925-1986) que había pasado su adolescencia y estudiado en Francia y Bélgica. Fue activo como periodista internacional gracias a las lenguas que dominaba —hablaba inglés, neerlandés y francés-, y a finales de los años cincuenta trabajó como corresponsal del diario Pueblo en Ámsterdam, luego fue agregado cultural en Londres. En paralelo desarrolló una carrera de novelista y en 1967 obtuvo el Premio Nacional de Literatura por El otro árbol de Guernica. No es de extrañar, pues, que en su introducción se presente como un novelista español al que se le ha encargado una colección de cuentos destinada a un público holandés (Castresana 1959: 8). El compilador destaca la riqueza del patrimonio cuentístico español y la consiguiente dificultad de presentar una selección representativa de más de medio siglo de producción y que dé una imagen de la sicología colectiva española. De la traductora Gertie Evenhuis, cuyo nombre solo figura en la contraportada, no conocemos más traducciones que esta. Fue profesora de enseñanza media y en 1958 escribió su primera novela juvenil, género en que conseguiría grandes éxitos durante tres décadas. En el periódico De Telegraafapareció una breve reseña, bastante crítica, del volumen. El autor lamenta que la mayoría de los cuentos no sean más que anécdotas naturalistas, pero nota auténticas joyas, entre las cuales figura «La novela en el tranvía» (s. n. 1959).

El acontecimiento que vuelve a colocar a Galdós en el panorama cultural de Holanda en los años setenta es una película: Tristana de Luis Buñuel, que se estrena en el festival de cine de Cannes en 1970. Llega a los cines holandeses en febrero de 1971. En las reseñas que mencionan al autor de la novela en la que se basa la película, no trasluce ninguna familiaridad con su obra, salvo alguna referencia a Nazarín, otra fuente de inspiración del célebre cineasta (Waller 1971). La popularidad de la obra de Buñuel constituye el punto de partida de la traducción de la novela. La editorial Arbeiderspers la encargó a Robert Lemm y la editó en 1974. En la portada figura una foto de la película: Catherine Deneuve / Tristana se acerca a la estatua yacente del cardenal Tavera, lo que implica que es la fama de la película la que debe atraer a los lectores potenciales. Tristana fue la primera traducción publicada del que iba a convertirse en uno de los traductores del español más reputados del ámbito neerlandés: Robert Lemm. Al texto de la novela le sigue un epílogo en el que Lemm ofrece los datos biográficos imprescindibles sobre el autor y su época y lo sitúa en la traducción de la gran novela decimonónica europea, por un lado, y por otro en la continuidad de la tradición española. Destaca la conexión con Cervantes (ambos jugaron con la crítica y transformación de un género popular, la novela de caballerías en un caso, el folletín en otro) y con Quevedo, lo que lo emparenta con Valle-Inclán y con Buñuel. Lemm ha desarrollado una brillante trayectoria de traductor 
y ensayista, tradujo entre otros a Fray Luis de León, Unamuno, Borges, José Donoso y Alejo Carpentier y en 1979 recibió el premio de traducción más importante del ámbito neerlandófono, el premio Martinus Nijhoff, por sus traducciones de literatura latinoamericana. El 20 de septiembre de 1975, Jacques den Haan publicó una reseña del libro. Incluso si se acepta que Galdós fue el autor más fructífero e importante del siglo XIX español, el crítico se pregunta si realmente habría aún quien se interesara por este «bodrio victoriano» (Haan 1975). Plantear la pregunta así es contestarla, teniendo en cuenta que quien la formula fue un introductor entusiasta de Henry Miller y James Joyce. ${ }^{7}$ El ensayista, traductor y ahora catedrático de literatura española de la Universidad de Nimega, Maarten Steenmeijer, publicó en 1980 un artículo en la revista Literair Paspoort titulado «Eindelijk vertalingen van Benito Pérez Galdós» («Por fin traducciones de Benito Pérez Galdós») en el que discute la importancia del escritor, que sigue siendo un desconocido para el público holandés debido a la convicción estereotipada según la cual la literatura española ya no tiene gran cosa que ofrecer después del Siglo de Oro. Steenmeijer coloca a Galdós a la altura de los grandes realistas del siglo XIX y esboza su trayectoria. Después presenta la traducción de Miau (1979, comentario al que volveremos) y de Tristana. Pone de relieve la doble lectura que permite esta figura: la reivindicación de mayores posibilidades vitales e intelectuales para las mujeres, o el necesario fracaso de la liberación de la mujer en el contexto decimonónico. Termina elogiando el virtuosismo del traductor.

El 14 de noviembre de 1978 sale en el periódico De Volkskrant una entrevista con un redactor de la editorial Het Spectrum, que ha lanzado una nueva serie llamada «Prisma Klassieken». Se trata de una colección de libros de bolsillo dedicada a los clásicos de la literatura europea. Entre los libros previstos para el año 1979 figuran, entre obras de Hawthorne, Fontane, Flaubert, Thomas Hardy, Goethe, Voltaire, Henry James, Heine, Swift y Rousseau, Miau de Benito Pérez Galdós (Odijk 1978). El traductor, Roelof Gerrit Groeneboer (1920-2015), acerca del cual no hemos podido reunir más información, había publicado previamente la traducción de Relato de un náufrago de Gabriel García Márquez para la editorial Meulenhoff de Ámsterdam en 1977. La traducción de Miau contiene, además del texto novelístico propiamente dicho, cuarentainueve notas explicativas (Galdós 1888/1979: 261-263), un epílogo del traductor (264-267) así como información biobibliográfica sobre Galdós (272-273). El epílogo trata del ambiente en que creció Galdós en Las Palmas, su descubrimiento de la vida capitalina y su creciente interés por la turbulenta historia reciente de su país, así como su trayectoria ideológicaliteraria, haciendo hincapié en las Novelas contemporáneas, su posterior carrera de dramaturgo y sus últimos años económicamente difíciles.

Un cronista literario del periódico De Telegraaf observa el 29 de diciembre de 1979 que el año literario ha sido muy productivo y menciona la traducción de Miau «del autor que también había escrito Tristana, filmada por Buñuel», poniendo de relieve una vez más que si Buñuel tenía presencia en el panorama cultural holandés, Galdós aun no la tenía tanto (Sitniakowsky 1979). La traducción fue reseñada por Barber van de Pol para NRC Handelsblad el 4 de abril de 1980. Barber van de Pol (1944) es la traductora más importante de obras literarias del español al neerlandés. Ha traducido a numerosos autores latinoamericanos (Borges, Cortázar, Onetti), Los sueños de Quevedo y Don Quijote de

7 Véase el perfil del autor en https://www.dbnl.org/auteurs/auteur.php?id=haan009. 
Cervantes (1997). En 1975 ya había recibido el premio de traducción Martinus Nijhoff por sus traducciones de literatura latinoamericana. Su formación de hispanista se transparenta en la reseńa, que empieza por situar a Galdós como renovador de la novela española a la que aporta la observación de la vida en la ciudad y el análisis sicológico. Se pregunta por qué el traductor no tradujo el título al neerlandés, ya que en este idioma la onomatopeya para el maullido es «miauw». Destaca la importancia de los diálogos que dan a la novela, cuyo escenario principal es el salón de la casa de la familia Villaamil, un fuerte carácter teatral cómico e imagina a varios actores holandeses conocidos representando a algunos personajes de la novela. Comparando Miau con Fortunata y Jacinta y con Tristana, llevada al cine por Buñuel, Miau no alcanza el mismo nivel, ya que los personajes se pueden dividir en buenos y malos, aunque más que los contrastes entre blanco y negro, importa el matiz. Galdós parece abogar en la novela por un cristianismo individual, entre el humanismo y el «Jesus-movement». ${ }^{8}$ Asocia el personaje de Ramón Villaamil con Josef K. de El proceso (1925) de Kafka, una referencia ya tradicional en la crítica galdosiana (Gullón 1960: 273-275). Por su carácter pictórico, Miau evoca la pintura de género, no la de Jan Steen (pintor holandés de escenas de género bulliciosas) sino la de Velázquez. La reseńa no toca la labor traductora propiamente dicha, Barber van de Pol se limita a mofarse de la asociación establecida por el traductor entre la finura con la que Galdós analiza la sicología femenina y sus numerosas queridas (Pol 1980). Maarten Steenmeijer, en su ya citada reseña de las traducciones de Tristana y Miau, observa que Galdós trasciende el naturalismo y el realismo, por ejemplo en el monólogo interior de Ramón de Villaamil, que ya anuncia el siglo Xx, y la complejidad de la figura del yerno de Villaamil. Elogia el lenguaje y el estilo de la traducción que contrasta positivamente, a su juicio, con el estilo confuso y la acumulación de datos en el epílogo (Steenmeijer 1980: 752-753).

Inspirada tal vez por la reseña de Barber van de Pol, la directora Guusje Eybers estrena en marzo de 1993 su adaptación de Miau para el teatro. Se trata de la producción de apertura de un nuevo teatro en La Haya, el Theater aan het Spui, lo cual explica que en algunas reseñas se dedica al menos tanto espacio al edificio y sus posibilidades como a la obra representada. Anneriek de Jong, la crítica teatral del periódico NRC Handelsblad, observa que en el mundillo burocrático madrileño ganan los que mienten, lo que explica la cesantía de Ramón de Villaamil. Reprocha a la directora su tratamiento temerario de la novela, lo que lleva a un resultado mucho más banal y grosero que el original. La representación solo supera el nivel de una farsa vulgar en el momento del suicidio de Villaamil (Jong 1993). La reseńa de Marian Buijs para De Volkskrant tampoco es elogiosa: no hay una línea dramática fuerte, la adaptación se pierde en senderos laterales y la puesta en escena se ahoga en el enorme espacio de la gran sala teatral, a pesar de los esfuerzos de los actores. El suicidio de Villaamil tiene aires de payasada (Buijs 1993). Para Hans Oranje, el crítico del periódico Trouw, la producción de Eybers tiene la ventaja de enseñar al público todas las posibilidades escénicas, acústicas y técnicas del nuevo teatro, ya que los actores se persiguen subiendo escaleras hasta en las alturas, pero la representación en sí le parece un sinsentido (Oranje 1993). Los comentarios de Peter Liefhebber

8 El movimiento cristiano juvenil que proponía la vuelta a las bases evangélicas y que fue muy popular en los ańos setenta. 
para De Telegraaf van en el mismo sentido. Declara no saber dónde termina Galdós y dónde empieza Eybers, pero el resultado es una representación aburrida (Liefhebber 1993). Todos los comentaristas observan que la directora juega con imágenes abiertamente sexuales y religiosas. Nos parece que esta interpretación de Miau podría ser de inspiración buñueliana antes que galdosiana.

\section{Galdós en la «SpaAnSE BibliotheeK» De MenKen Kasander \& Wigman}

En 1993, Paul Menken empieza en Leiden una pequeña editorial, Menken Kasander \& Wigman. Su interés por las literaturas de España surgió durante su estancia de cuatro años en el país (Velzen 2010). A lo largo de los años ha construido un catálogo de autores españoles, de lengua catalana y castellana, y latinoamericanos que comprende novelas de los siglos XIX y XX de autores como Baroja, Unamuno, Narcís Oller, Josep María de Sagarra, Rafael Chirbes y Rodrigo Rey Rosa (Menken 2016). También ha publicado entre 1998 y 2004 una selección de seis novelas de Galdós, que en la actualidad también están disponibles como libros electrónicos. La primera de la serie fue Marianela, traducida por Elly Bovée (Pérez Galdós 1878/1998). Se trata de una traductora del español y del catalán con un currículum nutrido, que comprende novelas de Mercé Rodorera, Álvaro Pombo, Luis Landero, Álvaro Cunqueiro, Ángeles Mastretta, Emilia Pardo Bazán y Adelaida García Morales. A la novela propiamente dicha le sigue un epílogo de Manuel Vázquez Montalbán que ya contaba con varias novelas traducidas al neerlandés. Destaca el carácter único de Marianela que no se puede clasificar ni entre las novelas de tesis ni entre las contemporáneas, sino que se puede leer como el último pecado juvenil posromántico del autor. La grandeza de Galdós, entre el canon de Balzac y Zola, está en su búsqueda de una forma novelesca adecuada para retratar a la Espańa deficiente de su tiempo (Vázquez Montalbán 1998).

Sander de Vaan empieza su reseńa para De Volkskrant con la referencia que más familiar podía resultar al lector holandés: la Tristana de Buñuel. Marianela no solo proporciona una imagen de los contrastes sociales en la España del siglo XIX, sino que presenta una historia conmovedora de todos los tiempos. Destaca el placer de narrar que emana del libro y su estilo fluido. Galdós es partidario del progreso científico, pero también muestra que los que «ven» suelen dejarse cegar por las apariencias. Esto es lo que convierte la novela en un libro intrigante (Vaan 1999). Maarten Steenmeijer dedica otra reseńa a la novela en la revista Vrij Nederland. Plantea el porqué de las pocas traducciones de Galdós. El fenómeno no solo se explica por el desconocimiento sobre la producción cultural de Espańa en el resto de Europa, una causa ya apuntada por el mismo Galdós, sino por la gran cantidad de sus obras y la falta de consenso sobre cuál es su obra maestra, lo cual impide un perfil mercadotécnico claro. El contraejemplo es Clarín, autor de solo dos novelas, cuya Regenta se reconoce unánimemente como la mejor, y ahora, después de más de cien ańos, La Regenta está ocupando el lugar que se merece entre las obras maestras de la novela decimonónica internacional. (El propio Steenmeijer y Barber van de Pol habían traducido La Regenta unos pocos años antes, en 1992). Steenmeijer se alegra por el programa galdosiano anunciado por la editorial. Presenta Marianela como una novela de ideas, en la que tres personajes representan las fases evolutivas de la humanidad distinguidas por Auguste Comte: Marianela, la teológica, Pablo, la metafísica 
y Golfín, la positiva. Steenmeijer retoma aquí una lectura tradicional de la novela expuesta por Joaquín Casalduero (1970). La muerte de Marianela, que Golfín no supo prever, sacude sus convicciones racionalistas. A pesar de los giros melodramáticos de la intriga y de los diálogos altisonantes, la novela sigue en pie gracias al humor de Galdós, que da alas a la tragedia, y al final irónico de la novela, cuando unos turistas ingleses fabulan en unas "Sketches from Cantabria» una imagen totalmente falsa y estereotipada de la mujer española (Steenmeijer 1999).

En 2000 salió la traducción de Fortunata y Jacinta de la mano de Adri Boon (1961- ). Boon ha publicado hasta la fecha más de sesenta traducciones del español, portugués, catalán y gallego. Su palmarés comprende autores como Eça de Queiroz, Javier Cercas, Salvador Espriu, Isabel Allende, José Pla, Fernando Savater, César Aira, Antonio Muñoz Molina y Clarice Lispector. Añade un epílogo en el que entreteje en un relato biográfico sobre el autor los datos históricos relevantes para situar su obra. Destaca la amplitud del mundo creado en la indiscutible obra maestra de Galdós, no solo en cuanto al número de personajes sino también por su interrelación con otras novelas del cosmos galdosiano. Del mismo modo, el tiempo de la historia, los ańos turbulentos entre la Gloriosa y la Restauración borbónica, se amplía hasta comprender gran parte del siglo y la geografía se ensancha desde las calles de Madrid a los lugares más remotos del país. Expone el virtuosismo con el que el autor muestra el impacto de la Historia con mayúscula en la trayectoria vital de los personajes, en primer lugar seres fascinantes de carne y hueso y al mismo tiempo representantes de su clase. Hace hincapié en la fuerza y riqueza de análisis de las figuras femeninas, no solo las protagonistas sino también Guillermina Pacheco y Mauricia la Dura. Orienta la atención del lector hacia las figuras quijotescas que pueblan la novela (Boon 2000).

La traducción tuvo reseñas favorables. El filósofo e hispanista Peter Venmans99 (1963) empieza su crítica para el periódico De Volkskrant con la tradicional comparación entre Balzac y Galdós. Observa que Fortunata y Jacinta es una novela urbana, aunque los escenarios principales son interiores, ya que son las pasiones las que echan a los personajes a la calle. Jacinta, la esposa decente, se convierte en personaje de novela gracias a su pasión por ser madre. Fortunata seguirá dando tumbos a lo largo del relato entre su deseo de respetabilidad y su pasión por Juanito. Aunque el crítico considera anticuada la visión paternalista sobre la pobreza y el determinismo sicológico, estima que Galdós es un virtuoso de la novela que lo pone todo al servicio del arte de narrar (Venmans 2000). La italianista y crítica literaria Inge Lanslots publicó una reseńa en el suplemento cultural del periódico belga neerlandófono De Financieel-Economische Tijd. El título del artículo «De Balzac van Madrid» constituye el puente para llevar al lector de la tradición literaria francesa, conocida, a la literatura española, desconocida. Destaca la tolerancia del autor que se rebelaba contra el fanatismo religioso. Como Balzac, Galdós presenta la burguesía como la clase ascendente del siglo. La crítica describe la relación entre Jacinta y Fortunata como el quiasmo matrimonio-esterilidad frente a infidelidad-fertilidad. Ve una estructura cruzada similar en Marianela: se oponen la belleza interior y exterior, la ceguera física y espiritual. En Fortunata y Jacinta prima la posición de la mujer. Jacinta adquiere al final de la novela una asertividad no conforme con su papel social. Fortunata desea

9 Véase el perfil del autor en https://www.dbnl.nl/auteurs/auteur.php?id=venm003. 
emanciparse y en esto se parece a Tristana (conocida gracias al cine de Buñuel). Fortunata resulta totalmente condicionada por su origen y su falta de educación, y en esto se transparenta la influencia de Zola, aunque Galdós no sigue los planteamientos naturalistas a la letra. Para esta crítica, Galdós no alcanza el nivel de Balzac, debido a las intervenciones artificiosas del narrador y de la repetitividad. La novela no se escapa del provincialismo de la España de su época.

Ger Groot ${ }^{10}$ (1954), filósofo, traductor de obras filosóficas y crítico literario, empieza su reseña para $N R C$ apuntando a la pobre presencia de Galdós en traducción neerlandesa y elogiando el proyecto de la editorial Menken Kasander $\&$ Wigman. Según Groot, tanto Jacinta como Fortunata actúan movidas por la esperanza, la primera por la esperanza de ser madre, la segunda, por la de una existencia decente. El centro matemático que las une es el hombre que las engaña a ambas. Groot comenta las diferencias entre $L a$ Regenta de Clarín y Fortunata y Jacinta: mientras Galdós observa, Clarín construye. Clarín escribía como Flaubert, unas pocas obras, Galdós como Balzac, una plétora de novelas. Su intención difería de la de Clarín: sus novelas constituían un proyecto nacional, apuntando hacia el progreso de la sociedad. Destaca también la importancia del humor, y remite al prólogo de Galdós para La Regenta, en el que reivindica la tradición de la novela picaresca. Galdós descubre la auténtica democracia española en la promiscuidad de las clases sociales, no en las débiles estructuras políticas. Pero con los años surge la duda sobre una posible solución social para España y Galdós busca la salud en los valores cristianos, en novelas como Misericordia y Nazarín (Groot 2000). Maarten Steenmeijer escribió una reseña para la revista Vrij Nederland. Para Steenmeijer, Fortunata y Jacinta constituye, junto con Don Quijote de Cervantes y La Regenta de Clarín, la cumbre de la novela española. Apunta que si la asociación Fortunata-pueblo y Juanito-burguesía decadente resulta evidente, la definición de Jacinta y Maximiliano lo es mucho menos. Le llama la atención que la última palabra la tenga Maximiliano y que Jacinta recupere una fuerte presencia al final de la novela. El niño que le confía Fortunata le asegura la autonomía emocional y, como Maximiliano, empieza a usar la imaginación para transformar la realidad. En una época de positivismo y pragmatismo, la imaginación debe seguir en el poder, una convicción que Galdós comparte con Clarín y Emilia Pardo Bazán. En cuanto a temperamento literario, destaca que Clarín fustiga las miserias de sus personajes a partir de un descontento radical con la Espańa de su tiempo, mientras que Galdós se acercaba a la realidad con la sonrisa y estaba casi en pie de igualdad con sus personajes, a los que introduce ampliamente, lo que da lugar a un estilo a veces prolijo (Steenmeijer 2000).

La única reseńa que menciona al traductor es la de Jan Baes para De Leeswolf, una revista destinada a las bibliotecas públicas de Flandes y sus usuarios. Elogia la prosa superior y deliciosamente ironizante de la novela, que oscila entre el humor y el drama y que fue transpuesta magníficamente en un neerlandés fluido por Adri Boon (Baes 2000).

El año 2001 ve la publicación de Tormento y La de Bringas (Mevrouw Bringas), traducidas respectivamente por Frans Oosterholt y Elly Bovée. Frans Oosterholt ha traducido una serie de obras del español y del catalán para la editorial de Paul Menken, entre otros Mercé Rodorera, Pío Baroja, Álvaro Pombo y Narcís Oller. Adri Boon empieza su

10 Véase el perfil de Groot en https://www.dbnl.nl/auteurs/auteur.php?id=groo057. 
epílogo de Tomento atribuyendo a la escritura galdosiana rasgos posmodernos: el inicio y el cierre presentan en un diálogo teatral a Ido del Sagrario, escribidor de folletines melodramáticos con jóvenes desamparadas como protagonistas, un marco que ofrece una visión edulcorada sobre el tema, central en la novela, de la situación de dependencia total de la mujer pobre. La novela se enmarca en las Novelas contemporáneas, en las que el autor quiere desvelar el espíritu de la época, en una empresa similar a la de La comédie humaine de Balzac y el ciclo De tandenloze tijd (El tiempo desdentado) de un autor holandés, A. F. Th. van der Heijden. El trasfondo lo constituyen los años turbulentos anteriores a la Gloriosa, años de quiebra de un régimen en que el único valor sólido es el del dinero y en que la moral cristiana auténtica se ha sustituido generalmente por la hipocresía. Rosalía de Bringas se desvive por las apariencias y esclaviza a la joven huérfana Amparo. La salvación se presenta en la figura de Agustín Caballero, un indiano enriquecido, diamante en bruto que resiste a las tentativas de encapsulación de Rosalía. La pareja sale al extranjero para vivir su romance, única manera de escapar al qué dirán (Boon 2001a). Adri Boon también se encargó del epílogo de Mevrouw Bringas. Llama la atención del lector hacia el paralelismo entre la decadencia del régimen de Isabel II y la debacle de la familia de Bringas, que ocupa un piso en las alturas del palacio. Tanto la reina como la protagonista de la novela quieren gastar lo que no tienen. Rosalía de Bringas compra frenéticamente ropa de lujo a escondidas de su marido avaricioso y cada vez más ciego, en el sentido literal y en el figurado, y cuando queda aplastada por el peso de las deudas y la presión de los usureros, se pone en venta ella misma, olvidándose de determinar previamente el precio de la mercancía (Boon 2001b).

Como las traducciones se publicaron al mismo tiempo, las reseñas ofrecen un comentario combinado. En su reseña para el periódico belga neerlandófono De Morgen, Peter Venmans se pregunta por qué habría que leer a un autor superado en el panorama europeo por Balzac, Dickens, los grandes rusos y Eça de Queiroz. Considera ambas novelas como historias ligeramente moralizantes sobre la presión del conformismo. Galdós muestra lo que se esconde detrás de la fachada pequeñoburguesa. Aunque los giros de la intriga son a veces ridículos, lo que salva estas obras es el humor. A este respecto, Galdós se distancia de la tradición del pesimismo hispánico radicado en el barroco y se reivindica de una tradición más alegre y ligera: la de la novela picaresca y del Quijote. Elogia la traducción de Oosterholt que ha conservado la agudeza, la ironía y el estilo galdosianos (Venmans 2001). Maarten Roest, crítico de literatura española y latinoamericana para el periódico holandés Trouw considera que no se necesita recurrir a la historia de la literatura española para ganar lectores para Galdós. Tormento es un libro que seduce inmediatamente. A un relato que a primera vista podría ser materia de una telenovela, el autor le da un giro grotesco. Supo combinar unas intrigas dramáticas con cuestiones morales y sociales profundas, en un lenguaje fresco y claro. Elogia la traducción excelente (Roest 2001). Ger Groot, en una reseña para $N R C$, destaca la intención crítica que tenía Galdós con las Novelas contemporáneas. Según él, las mejoras no podían provenir ya de los poderes establecidos sino del vigor del pueblo y del espíritu de emprendimiento, representados en Tormento por Amparo y Agustín Caballero. Para Groot, Galdós no pertenece a la cumbre de la literatura mundial, porque no cultivaba el arte de la escritura, pero su obra invita a un viaje hacia atrás en el tiempo: a una Espańa que pasó definitivamente. Elogia la claridad de las traducciones (Groot 2001). 
Miauw sale en 2002, en traducción de Adri Boon, que se encarga también del epílogo. El traductor pone el acento en el hecho de que en la ronda de despidos que le cuesta el empleo a Villaamil, cae el único funcionario responsable, inteligente y con un serio proyecto para el saneamiento de las finanzas públicas, mientras que otros menos probos pero más hábiles en el juego burocrático conservan el puesto. Las mujeres de su entorno son aficionadas al teatro, ese espejo falso de la vida real y viven por encima de sus posibilidades. Villaamil se da cuenta de que en lo particular ha fallado como pater familias, del mismo modo que el Estado falla en su organización de la vida de la nación. Observa la importancia del humor en la narración de la decadencia de un hombre probo que ya no acepta vivir en su entorno ni consigo mismo. El ambiente claustrofóbico y la pequeñez de los personajes causan una sensación de angustia en el lector (Boon 2002). Esta novela fue reseñada por Ger Groot para $N R C$. La fuerza motriz detrás de la obra galdosiana es la crítica social dirigida contra una burguesía que impide el paso a la fuerza vital de las clases inferiores. La falsa elegancia de la esposa del protagonista y la calidad de empleado público de este son un ejemplo de lo que Galdós critica. Miauw supera a muchas Novelas contemporáneas gracias a la compasión retenida con la cual Galdós retrata a su protagonista tragicómico. Elogia la traducción inspirada de Adri Boon (Groot 2003). Maarten Steenmeijer se encargó de una breve nota para NDB Biblion, una organización de servicios para bibliotecas públicas holandesas. Describe la novela como una de las cumbres de las Novelas contemporáneas, considera que el desastre personal del protagonista refleja el profundo pesimismo del autor sobre la situación de su país, aprecia el epílogo instructivo y elogia la iniciativa de la editorial que consiste en ofrecer al lector un conjunto de obras traducidas de Galdós (Steenmeijer s. a.). Jan Baes, en su comentario para De Leeswolf, observa que Galdós retrata de modo penetrante e hilarante a la vez el mundillo burocrático espańol. Villaamil perece porque, como Don Quijote, no supo mirar de frente la realidad (Baes 2003).

La última novela de Galdós traducida hasta la fecha es Misericordia, que en neerlandés se titula Mededogen (Pérez Galdós 2004). El traductor es Frans Oosterholt, que también redactó el epílogo. Describe la evolución literaria e ideológica de Galdós desde los inicios hasta el momento en que desconfía definitivamente de la burguesía como fuerza motriz que llevará al progreso y contempla los estragos del capitalismo, en la forma de una proletarización de las clases bajas. Galdós no cree en la revolución proletaria, se adhiere más bien a una forma moderada de socialismo a lo Tolstói. Oosterholt compara esta postura con la de un conocido escritor holandés contemporáneo de Galdós, Frederik van Eeden. La protagonista, Benina, es la representación de este ideal evangélico de solidaridad. El traductor destaca el papel ambiguo de las buenas obras organizadas por la Iglesia, sostén de un antiguo régimen caduco. El mendigo Almudena, judío al que todos toman por moro por su origen marroquí, es el recuerdo de la España plural de la Edad Media, aplastada por la España imperial de los Reyes Católicos. Pero de esta España imperial ya no queda nada al final del siglo y Galdós condena a los personajes que intentan escapar de la realidad retirándose en la estéril nostalgia de un pasado heroico. El revés de fortuna final -la familia de dońa Paca se hace rica, Benina es encerrada por mendigaes temporal, porque Benina resurge en toda su fuerza al final del libro. Galdós anticipa desarrollos literarios posteriores al convertir el producto de la imaginación de Benina, el sacerdote don Romualdo, en un personaje «de verdad». El traductor apunta también 
algunas observaciones sobre su traducción: ha resistido la tentación de «embellecer» la prosa galdosiana eliminando algún adjetivo superfluo o rectificando alguna metáfora. Galdós necesita el ritmo de lectura de un lector voraz y la distancia que conviene para mirar un cuadro impresionista (Oosterholt 2004).

Esta traducción ya no recibió reseñas en la prensa nacional holandesa. Localizamos un comentario entusiasmado de Luc de Rooy para Babel, la revista de la Facultad de Humanidades de la Universidad de Ámsterdam. Compara la novela con un cuadro de Brueghel, Los mendigos, en el que el pintor traducía visualmente el proverbio neerlandés según el cual la mentira, como el manco, va con muletas, lo que significa que la sociedad está basada en la mentira y la injusticia. He aquí el mundo en que se mueve Benina. El crítico estima que es de justicia que se haya traducido el Balzac de España y recomienda su lectura (Rooy 2005). Jan Baes escribe un extenso comentario para De Leeswolf. La novela muestra a su juicio que Galdós es un fundador de la literatura española moderna gracias a su juego con la ficción y la realidad. El libro está anclado en una tradición española en la que también se mueven cineastas como Buñuel y Almodóvar. La pintura de la miseria de los mendigos no es nada complaciente y evoca la escena del banquete de los mendigos en Viridiana de Buñuel. Solo Benina y su amigo marroquí consiguen dar sentido a sus vidas porque se dedican a los demás. El crítico destaca la crítica social de la novela y su significado político. Galdós ya no cree que el remedio para Espańa pueda surgir de la clase media y vuelve a los principios evangélicos a la zaga de Tolstói. Como otras novelas galdosianas, Mededogen contiene páginas preciosas y contribuye a entender la España de fin de siglo (Baes 2005). También se publicó una reseña elogiosa de la novela en una revista cultural en línea, bastante inspirada por el epílogo del que se reproducen fragmentos sin citar. La periodista Monique Jacobs elogia la iniciativa de la editorial Menken Kasander \& Wigman para dar a conocer a Galdós en el ámbito neerlandés. Describe la novela como una "comédie humaine» entreverada de humor. El autor opone la resistencia de Benina a la pasividad de los representantes de la burguesía decadente que se limita a soñar (Jacobs 2005).

\section{CONCLUSIÓN}

La recepción de Galdós en el ámbito neerlandés en vida del autor se caracteriza por la ausencia de lo que actualmente se considera como la parte más canónica de su obra, en primer lugar Fortunata y Jacinta, y las Novelas contemporáneas en general. Es sorprendente el poco tiempo que transcurre entre la publicación de las primeras novelas de Galdós y los resúmenes comentados por P. N. Muller, el único crítico que demuestra un interés activo por los Episodios nacionales. Algunas novelas de las llamadas «de tesis» se publican en años no demasiado alejados de su publicación, entre 1883 y 1891 . La recepción es positiva, la lucha ideológica presentada en Doña Perfecta y La familia de León Roch queda descrita desde la distancia, como un conflicto al que los críticos holandeses quedan ajenos. El estreno tumultuoso de Electra en 1901 da lugar a numerosos artículos largos y breves en la prensa holandesa y había creado una gran expectación ante la representación de la obra en traducción. Como en Holanda la convivencia de grupos ideológicos y religiosos distintos se daba en un clima relativamente distendido, en comparación con España, la crítica teatral se quedó algo decepcionada y se preguntó qué había en 
Electra capaz de despertar tanta indignación entre los católicos. No es de extrañar que en Bélgica, que vivía un conflicto ideológico algo similar al español entre los católicos por un lado y los anticlericales (liberales y socialistas) por otro, un crítico católico, Jules Persyn, supiera explicar a su público en qué residía el supuesto veneno de Electra. Hasta el comienzo del siglo, el lector de lengua neerlandesa ha podido conocer, pues, solo la producción más marcada política e ideológicamente de Galdós. En el siglo XX, la vigencia de la crítica galdosiana a la sociedad de su tiempo ha pasado para el lector extranjero y Galdós desaparece del panorama neerlandés durante décadas.

Con el paso del tiempo, se observa una especialización y profesionalización crecientes de traductores y críticos. Frente a los traductores y críticos decimonónicos, escondidos detrás de iniciales, encontramos a Adèle Godoy que reivindica públicamente su concepción de la traducción en la prensa y a Adri Boon que no solo se encarga de traducir varias novelas sino que orienta además su recepción gracias a los epílogos que escribe para las novelas que no traduce. Mientras no siempre queda claro cómo los traductores del siglo XIX se formaron, a partir de los años sesenta traducen y discuten la obra galdosiana unos profesionales de la traducción y de la crítica literaria con amplia formación académica de traductores e hispanistas y unas listas de publicaciones imponentes.

Para interesar al lector por la obra de un autor español desconocido salvo para los pocos estudiosos de la literatura espańola, los traductores en sus epílogos y los críticos literarios buscan términos de comparación y los encuentran en los grandes realistas europeos, sobre todo Dickens y Balzac, a veces Zola, menos aún Tolstói. Otro apellido de referencia es Buńuel, cuya película Tristana ha calado más hondo en la memoria cultural neerlandesa que la novela de Galdós. El desconocimiento de la literatura española de la que ya se quejaba P. N. Muller en 1872 sigue en pie hasta cierto punto, aunque la «ofensiva» de la editorial Menken Kasander \& Wigman que presenta un conjunto de seis novelas notables, puede contribuir a que Galdós ya no necesite la comparación con lo ajeno para ocupar su lugar en la visión que tenemos en el ámbito neerlandófono del canon realista europeo. También se observa una discreta presencia comparativa, en las reseñas más recientes, de Clarín, lo que parece apuntar a un lugar específico de la novela española decimonónica, por derecho propio, en el panorama del lector culto de lengua neerlandesa. 



\section{CAPÍTULO II}

Estudio de la correspondencia entre Pérez Galdós y sus traductores alemanes

Amalia Bosch Benítez

Universidad de Las Palmas de Gran Canaria

\section{INTRODUCCIÓN}

En el archivo de la Casa-Museo Pérez Galdós, en Las Palmas de Gran Canaria, se conserva la correspondencia que el escritor sostuvo en vida con personalidades de su época. Las cartas están digitalizadas y se pueden consultar en la página web de la institución. Este epistolario es, sin duda, de lo más valioso para los investigadores galdosianos, pero nuestra línea de trabajo no se orienta a este campo en concreto. A nosotros nos interesa, más bien, la correspondencia que sostuvo con personas que se postulaban como traductores de sus obras, en Alemania. Este material no se encuentra disponible en la web de la institución. Por ese motivo, solicitamos una copia que se nos facilitó en PDF de las cartas que Galdós recibió procedentes de Alemania, redactadas en español o en francés.

La correspondencia con el escritor procede de todos los rincones del mundo, y en los años 60 se abordó una clasificación:

\footnotetext{
«El primer intento de la clasificación racional del Archivo epistolar y documental de Galdós lo realizamos nosotros en un trabajo publicado en la revista El Museo Canario, bajo el título de "Índice del Archivo Particular de Galdós” (R. M. C. n.o 7784, años, 1961-67) (De la Nuez 1990: 13)».
}

De la Nuez (1990: 14) se ocupó de cuantificar el número de cartas procedentes del ámbito alemán que se conserva en la Casa-Museo Pérez Galdós y las clasificó atendiendo al remitente de las epístolas; a veces son meras tarjetas postales, o de visita, o incluso fotos dirigidas al escritor. En esta ingente tarea de clasificación se aporta el dato de que se conserva un total de 79 cartas procedentes de Alemania, 39 de Austria, y 6 de Suiza.

En la actualidad, no obstante, una vez consultado el archivo parece que se han incorporado algunas cartas más, pues se contabiliza un total de 86 cartas procedentes de Alemania, 36 de Austria y solo 3 de Suiza. Esta disparidad en la cantidad de cartas seguro que tiene una explicación administrativa y archivística, pero no es el objeto de nuestro trabajo. Nos limitamos a exponer los números que se manejan en la actualidad. Esta cata- 
logación por países aún puede variar, pues nosotros mismos hemos detectado alguna carta procedente de Austria que, sin embargo, figura en el registro como si procediera de Alemania.

La mayor parte de las cartas dirigidas al escritor se refieren a propuestas de traducción de sus obras, y solo en algún caso se trata de simples admiradores de las mismas. Es el caso de Emil Wolff director de un instituto de enseñanza media de Schleswig-Holstein, Alemania. El remitente redacta una carta con fecha 30 de abril de 1880 (carta número 175) en la que transmite al escritor su emoción al leer la novela Gloria, ${ }^{1}$ pues deseaba compartir con él un análisis literario y filosófico sobre la temática de su obra. Esta carta es un exotismo en sí misma, ya que el remitente, sabedor de que don Benito no leía alemán, envía el original de la carta escrita en alemán de su puño y letra, pero acompañada de una traducción de la misma.

Decimos que es una curiosidad en sí misma, porque al final de la carta, es el traductor quien se disculpa ante don Benito e inserta la siguiente despedida:

«No habiendo aprendido el castellano por Gramática, me es sumamente difícil la traducción del alemán al español, y más si es de un poeta como el señor Wolff. Esperando que el señor Galdós con su privilegiada imaginación suprima [o supla, no está claro en el texto] mis defectos. Su amigo [sigue una firma ilegible]».

Esta carta podría parecer una anécdota, pero, en realidad, es la prueba tangible de que Galdós era leído y admirado en Alemania. Las demás cartas que componen este archivo corresponden, como decimos, a personas que se postulan como candidatos para traducir sus novelas. A veces, los corresponsales son directores de teatro o agentes teatrales, que entusiasmados por las comedias y dramas de Galdós, le instan a que les conceda el privilegio de traducirlas al alemán y representarlas en sus teatros.

Nosotros hemos acotado el campo de nuestro estudio a Alemania y hemos preferido dejar la correspondencia recibida desde Suiza o Austria, para incluirla en una investigación posterior restringida a estos dos países.

Nuestro estudio abarca la correspondencia recibida desde 1879 — que es la fecha en que se inicia una interesante correspondencia con August Hartmann, traductor de Gloria al alemán—, y se extiende hasta 1907, año de la última carta con corresponsales alemanes. Es decir, veintiocho años de actividad epistolar volcada en la representación de sus obras teatrales o en la traducción de sus novelas.

Que nosotros tengamos constancia, no existe un estudio del epistolario centrado en la relación entre Galdós y sus traductores o sus posibles traductores. Esta es la razón fundamental de nuestro trabajo: poner el foco en la actividad epistolar y traductora ejercida por esas personas en época de Galdós, en Alemania. En el proceso hemos encontrado nuevos datos que ayudarían a completar la bibliografía de las traducciones al alemán, con obras traducidas en vida de Galdós, pero aún no descubiertas por los especialistas. Aportamos datos e indicios de dónde podrían encontrarse esas traducciones.

1 Gloria se publica en Alemania, en diciembre de 1880, en traducción de August Hartmann. 
Como decíamos, el escritor recibe cartas de personas que se ofrecen para traducir su literatura. Si bien es cierto que algunos investigadores han reseńado la existencia de estas cartas, lo han hecho para ilustrar, exclusivamente, aspectos literarios o para analizar la calidad de las traducciones o la recepción de las obras de Galdós. Es el caso de Ramírez Jáimez (1993; 1995), quien comentó aspectos de la correspondencia del escritor con los traductores de sus novelas Gloria y Amigo Manso al alemán. De igual manera, Siemers (1993) analiza la versión al alemán de la novela Gloria realizada por August Hartmann en época del autor. En este artículo la investigadora se centró en la equivalencia pragmática de la traducción, pero, como decimos, ninguna de estas especialistas estudia el epistolario como un fin en sí mismo, sino como un medio para valorar la calidad, la acogida o la crítica que las obras de Galdós recibieron en Alemania.

Otros investigadores (López Jiménez 1990a, 1990b, 1993 y 1995; Bly 2009) analizan las traducciones al francés y las traducciones al inglés, respectivamente, y para este fin utilizan la correspondencia con sus traductores. Algunos autores han investigado el impacto periodístico que de la obra de Galdós se tenía en Francia. En particular, Pinacho (2016) recopila la publicación de noticias sobre Galdós en la prensa francesa, más concretamente en Le Temps. El artículo de esta especialista nos acerca a la dimensión literaria de Benito Pérez Galdós en la prensa francesa de su tiempo. Se analiza la presencia de menciones a Galdós y las compara con las de otros célebres autores de la misma época como Echegaray, Benavente y Blasco Ibáńez. El periodo investigado abarca desde el 10 de mayo de 1885 hasta 1920 y según Pinacho (2016: 67) arroja los siguientes resultados: «462 unidades periodísticas dedicadas a Galdós o en las que se menciona al autor, quedando Benavente, Echegaray y Blasco Ibáńez por detrás de él». Todo ello encaminado a demostrar la repercusión literaria de Galdós en Europa por la publicación o traducción de sus obras, pero no se olvida de la dimensión del escritor como hombre comprometido con su tiempo y afirma (2016: 83) que:

\begin{abstract}
"[..] no se puede ignorar o menospreciar el conocimiento de Galdós en Francia ni en el resto del mundo anterior a la publicación de una novela en un folletín o a los acontecimientos sucedidos a raíz del estreno de Electra, sino que desde antes, años antes, existía una imagen internacional que abarcaba aspectos no estrictamente literarios, por mucho que ambos ejemplos, es indudable, dispararan exponencial y definitivamente su popularidad, sobre todo, por todo lo que tiene que ver con la obra teatral, como se ha apuntado, por cuanto que engloba todas las facetas».
\end{abstract}

Peter Bly (2009), por su parte, decide abordar la repercusión y la influencia de la obra de Galdós a través del análisis de los artículos o reseñas publicadas por los críticos europeos. Nosotros nos fijaremos, exclusivamente, en el ámbito de lengua alemana estudiado también por Bly. Divide su investigación en cuatro bloques el primero desde 1870 hasta la muerte del autor; aquí incluye la traducción de Marianela, en 1888 y de El amigo Manso en 1894. Como se puede observar, se quedan en el tintero las traducciones al alemán recogidas por otros investigadores como serían Doña Perfecta (1886), Gloria (1880), además de Trafalgar (1896) o Electra (1901). En el siguiente bloque, incluye los años 1920 a 1950, el denominado periodo de entreguerras en el que no se tradujeron ni editaron novelas de Galdós. Existe en estos años una curiosidad editorial: Trafalgar (1925), una edición 
preparada para que los alumnos leyeran el texto en español, si bien muy resumido. Esta edición corrió a cargo del catedrático Gustav Haack de Hamburgo, y constituye el tomo 6 de una colección de literatura española editada para su uso como material escolar.

Bly continúa su investigación y analiza la publicación de obras de Galdós entre 1950 y 1970, años en los que comienza un tímido renacer de las traducciones y del interés por la obra de don Benito y se traducen novelas como El amigo Manso o Fortunata y Jacinta (1961), en Suiza. En Alemania, en ese periodo, se traducen Miau (1960), Misericordia (1962), Doña Perfecta (1963) y Tristana (1989). En cuanto a los Episodios Nacionales destaca la obra de Hinterhäuser, que aparece en versión española en 1963 y más recientemente, otra investigadora, Martino Alba (2010) escribe sobre la recepción de esta obra en Alemania y llega la conclusión de que son más los artículos que hablan sobre las novelas de Galdós que sobre los propios Episodios nacionales.

Pero, al igual que se ha hecho con las traducciones al alemán, tampoco estos especialistas hicieron una descripción o análisis del epistolario sostenido por el escritor con sus traductores, ni de su contenido específico.

\subsection{Estructura del trabajo: organización del material consultado}

Como hemos avanzado, manejamos un PDF que contiene la correspondencia digitalizada por la propia Casa-Museo Pérez Galdós. La institución las digitalizó respetando un estricto orden alfabético, no cronológico. A la hora de referenciar las cartas en nuestro trabajo, hemos utilizado dos datos para identificarlas: en primer lugar, la fecha en que está escrita, y, en segundo lugar, un número correlativo de orden. Este número es el que se despliega, por defecto, en el documento digitalizado y coincide con la paginación de este archivo digital. Lo hemos aprovechado para adjudicar un número a las cartas. Es decir, si referenciamos una de ellas como "carta número 132» estaremos, simplemente, utilizando el número de orden natural que se corresponde con la página del archivo en PDF, no a un índice documental específico, que no existe.

Hemos preferido agrupar las cartas por contenido temático, y no por orden alfabético. El tema coincidirá con la novela u obra teatral que el remitente desea traducir. Nos ha parecido que con este método se conseguía una mayor claridad para el lector. De haber procedido de manera exclusivamente cronológica o alfabética, habría un desorden temático que en nada contribuiría a ilustrar los objetivos de este estudio. Dentro de cada apartado temático sí se guarda un orden cronológico. Tendremos también en cuenta que, a veces, los corresponsales no elegían qué obra traducir, sino que dejaban a criterio de Galdós su selección.

Disponemos de las cartas procedentes de Alemania, pero no manejamos las cartas que Galdós remitió a sus traductores, pues se desconoce su paradero, línea de investigación que aún no se ha abierto. Aún así, hemos aportado fechas de las respuestas del escritor. ¿Cómo podemos saber este dato? Resulta fácil, porque en algunas ocasiones, el remitente hace mención a la carta de don Benito y reseña la fecha. Este modo de proceder era habitual en aquella época, porque no se podía tener la certeza de que las cartas llegaran, realmente, a manos del destinatario o si, por el contrario, se perdían por el camino. Por esa razón, el remitente volvía a escribir para decirle que no había obtenido respuesta a su carta, y que pudiera ser que no le hubiera llegado. A veces, se cruzaban las respuestas 
o no llegaban a tiempo, y eso trajo alguna consecuencia, como en el caso del traductor Carlos Schlimbach. ${ }^{2}$

En otras ocasiones, es el propio Galdós el que anota, de su puño y letra, comentarios sobre la respuesta que ha brindado a cada una de las epístolas. Esas anotaciones son de sumo interés en el estudio de los derechos de traducción otorgados, los plazos para realizar las traducciones y publicar las obras, o los plazos para la representación de sus obras de teatro, etc. En algún caso, el escritor retira los derechos de traducción a alguno de sus traductores al parecer por el retraso o por disconformidad con las cláusulas del contrato. ${ }^{3}$

\section{LOS TRADUCTORES DE GALDÓS AL ALEMÁN: REALES Y POTENCIALES}

Hablar de traductores al alemán implica, como es evidente, hablar de las traducciones aparecidas en Alemania, que pudieron materializarse o no como consecuencia del carteo entre escritor y traductores. Galdós recibió múltiples propuestas de traducción de sus obras, pero de algunas existe constancia de su publicación y de otras podremos inferir que se publicaron, a pesar de que no quede rastro del documento en sí o no se haya descubierto hasta el día de hoy.

Trataremos, exclusivamente, las traducciones que vieron la luz en vida de Galdós, pues son las que han dejado rastro en la correspondencia, cuyo contenido revelaremos. Ramírez Jáimez (1995: 97) aportó también una bibliografía de las traducciones de Galdós y afirmó que en vida del escritor solo se tradujeron seis de sus novelas: Marianela (1888 y 1903), Gloria (1880), El amigo Manso (1894), Doña Perfecta (1886), Trafalgar (1896) y un drama, Electra (1901). Esta última hemos comprobado que se traduce al alemán, pero no en Alemania, sino en Austria, en el Wiener Verlag. García Bolta (1993: 45) recoge la traducción de las siguientes obras: La fontana de oro (1872), Gloria $2 a$ (1880) y Gloria $2 b$ (1886), Marianela (1888), Freund Manso (1894) y Trafalgar (1896). A simple vista, se puede constatar que no parece haber un estudio preciso y definido sobre las traducciones publicadas en Alemania.

En este asunto de la bibliografía de obras traducidas al alemán, no parece haber uniformidad. Hernández Suárez (1972) lista nueve obras aparecidas en Alemania y correspondientes a traducciones de la época de Galdós. Incluye de nuevo Electra, que debemos eliminar de nuestro cómputo, pues como dijimos, se publica en Austria y no en Alemania. Quedan por tanto ocho, y el autor recoge también dos ediciones de Trafalgar; ahora bien, una de ellas, en realidad, no se corresponde con una traducción, sino con un material escolar de lecturas en español, que se usó en una región concreta del norte de Alemania en 1925, tal y como hemos reseñado con anterioridad. Si retiramos esa obra, nos quedaríamos en siete.

En esta bibliografía de Hernández Suárez no aparece, curiosamente, una de las traducciones a la que dedicaremos todo un subepígrafe de nuestro estudio: Doña Perfecta, traducida por Emilie Reichel, publicada en la editorial Pierson's (Dresden), en 1886 y

2 Carta de Carlos Schlimbach, fechada el 21 de octubre de 1897 (carta número 133). Schlimbach solicita derechos de traducción para cualquier novela. No recibe respuesta a sus cartas y cuando por fin llega la autorización, el traductor no puede asumir la traducción, porque se ha comprometido con otro autor.

3 Caso de Julius Schröder con Misericordia y Nazarín, carta número 141, de fecha 19 de diciembre de 1900 , en la que Schröder renuncia a la traducción. 
1903. A la vista de estas discrepancias, consideramos que merece la pena que se vuelvan a cotejar y revisar los datos de las traducciones al alemán.

Los especialistas han recogido en esos listados bibliográficos las obras traducidas en Alemania y editadas en formato de libro. Hacemos hincapié en este asunto, pues la edición en libro era una opción, frente a otra mucho más popular y efectiva, como era publicar en revistas, gacetas o en folletín, feuilleton, tema que sí tratan los investigadores de las traducciones al francés (López Jiménez 1990, 1993 y 1995) o al inglés (Bly, 2009).

Este dato es relevante, pues creemos que la lista de traductores y por lo tanto, el número de obras publicadas al alemán pudiera ser ligeramente mayor de lo que se ha expuesto hasta la fecha, si en ese cómputo se incluyeran las novelas traducidas y publicadas en la prensa de la época. Que aparecieran otras traducciones entraría dentro de lo razonable a la luz del volumen de cartas y de propuestas de traducir sus obras al alemán, debido al renombre y prestigio de los que gozaba Galdós en Alemania. A continuación procederemos a agrupar las cartas que se remiten, atendiendo a la novela que se pretende traducir.

\subsection{Doña Perfecta}

La novela se publica en España en 1876 y como hemos dicho es la única obra de la que se editan dos ediciones en Alemania. Nosotros hemos podido leer la 2. a edición de 1903. Su traductora fue Emilie Reichel, pero no se conserva ninguna carta entre esta traductora y el escritor, al menos en la Casa-Museo. No obstante, todo lo relativo a esa traducción resulta curioso e interesa exponerlo, pues fue motivo de carteo entre Galdós y August Hartmann, que fue el traductor de Gloria al alemán y también con un corresponsal, de quien hablaremos más adelante, pero del que desconocemos todo, salvo el nombre: O. Bartning.

La relación con su traductor, Hartmann, debía ser muy fluida y cordial. La novela Gloria traducida por él, vio la luz en diciembre de 1880, en la editorial de Ludwig Schleiermacher, en Berlín. La primera carta que se conserva de Hartmann, se refiere, exclusivamente, a la traducción de Gloria y está fechada el 12 de marzo de 1879 (carta número 51). Todas las cartas de Hartmann están redactadas en un correcto español, no en vano vivió unos ańos en Espańa con su mujer.

A medida que avanza la correspondencia entre los dos, el asunto de la traducción de Gloria pasa a un segundo plano y se observa que Galdós estaba preocupado por la traducción de Doña Perfecta, y traslada a Hartmann su inquietud. En el curso del carteo que mantiene con el traductor y más concretamente, en la carta fechada el 30 de septiembre de 1879 (carta número 55), Galdós le hace algún tipo de encargo con relación a la traducción de la novela Doña Perfecta. Hartmann hace mención a la carta de don Benito, fechada el 28 de julio. Y le escribe:

«Respecto de la traducción de Doña Perfecta, no he podido averiguar nada, y ruego a Ud. que en su contestación me indique lo necesario: nombre del periódico y el domicilio del mismo».

El subrayado es nuestro y nos interesa resaltar este dato, pues se refiere, naturalmente, a la dirección de algún periódico y es que, al parecer, alguien publicó la traducción de Doña Perfecta en prensa, y por lo que parece, don Benito albergaba serias dudas sobre 
la legalidad o autorización que hubiera concedido para dicha traducción, como veremos más adelante.

En otra de las cartas, fechada el 15 de diciembre de 1879 (carta número 59), Hartmann le pone al corriente de que su traducción de Gloria ya está en las librerías alemanas. Está muy contento con las críticas que recibe y hace mención a la carta que el escritor le dirige el 24 de noviembre de 1879. En esta, el escritor le propone que traduzca algunas de sus obras. Hartmann contesta encantado que así lo hará, y que empezará con Doña Perfecta. Pero lo pone en guardia, advirtiéndole de manera muy clara:

\begin{abstract}
«será indispensable que tomemos las necesarias medidas, que mis caminos no sean cruzados por aquella señora, que la traducción antes, mismo si fue en extracto. Pues hay toda probabilidad de que ella al saber la buena recepción de Gloria, de nuevo impondrá la idea de traducir la Doña Perfecta en completo y como libro. Si Ud. da la preferencia a mi, es menester que Ud. indague entre sus papeles las señas de la señora o el nombre del periódico lipsiense en que la novela fue publicada. Teniendo uno u otro averiguado, escríbamelo Ud., y yo daré los pasos necesarios para hacer desistir a la dama. Necesario será, que usted me adjunte una carta "oficial", en que me encargue de la traducción, retirando los derechos entregados a la señora de Leipzig y manifestando a ella sus motivos».
\end{abstract}

Se colige del fragmento que hemos seleccionado de esta carta, que Doña Perfecta, fue publicada en algún diario de Leipzig mucho antes de que saliera editada en libro por la editorial Pierson's. Hay que tener presente la fecha de la primera edición, que es del año 1886 y la segunda de 1903, y cotejarla con esta carta entre Hartmann y don Benito, pues data de 1879, es decir, siete años antes de que se publicara oficialmente por la editorial Pierson's. Galdós no parecía estar muy satisfecho con esta situación y por eso aprovecha la relación con Hartmann y el éxito que este le transmite con relación a la traducción de Gloria. Don Benito felicita a Hartmann en una carta que no conservamos, pero que está fechada el 1 de enero de 1880. El traductor responde a sus felicitaciones, en carta fechada el 24 de enero de 1880 (carta número 61) y regaña a Galdós diciendo:

«Hasta hoy he estado esperando, que Ud. me remitiera los informes que Ud. me prometió enviármelos [sic], y como me parece que Ud. lo habrá olvidado en sus muchos quehaceres, tomo la libertad de recordarlo a Ud. Pues antes de que esté arreglada la base en que construir la Doña Perfecta alemana, no puedo dedicarme a ese trabajo. Con la autorización que con su apreciada carta Ud. me envió y que le agradezco mucho, no puedo proceder hasta que sepamos quien es la persona, a quien Ud. había dado la misma autorización verbalmente, su nombre (con seguridad) y domicilio; o si esto no fuera posible averiguar, lo menos sea el nombre del periódico o revista y el año en que fue publicada aquella traducción. Ciertamente, entre sus papeles encontrará Ud. algo de esto; o sea por el sr. Don José Castro, su amigo».

Volvemos a subrayar el clarísimo indicio de que existió una traducción de Doña Perfecta en algún diario de la época, probablemente en la ciudad de Leipzig; aunque no tengamos la prueba documental, la publicación se infiere con toda claridad de estas cartas. 
En otra carta de August Hartmann, fechada el 12 de agosto de 1880 (carta número 63), el traductor responde a la carta del escritor, fechada el 1 de mayo. Al inicio de esta carta nos enteramos de que a Galdós le acontece una desgracia personal, que le ha impedido contestar con la fluidez habitual a su traductor y ya casi amigo. A Hartmann, curiosamente, y en la misma época, no le ha ido mejor, pues comparte con don Benito la tristeza que le ha producido la muerte de una de sus hijas y de su esposa. Esto en cuanto al tema personal, pero en lo tocante a la relación profesional, Hartmann queda abatido al enterarse por Galdós de que no podrá realizar la traducción de Doña Perfecta, como era deseo de ambos. Al parecer existe una traducción anterior de una tal Wilhelmina, y Hartmann da rienda suelta a su desesperación:

«Lo que Ud. me participó respecto de la señora Wilhelmina y de su traducción de Doña Perfecta, me ha desanimado por completo. Confiando a lo que Ud. me había dicho en cartas anteriores, yo había principiado con la misma traducción y ya adelantado bastante. Única cosa que me queda a hacer en las circunstancias actuales, es parar en mi trabajo o mismo calentar la estufa con él. Pues en este pobre país no hay lugar para 2 traducciones de una obra de ese género. Una sola ya habrá que luchar desesperadamente por su existencia. Así me pasa con la Gloria, la mejor de lo que Ud. ha escrito y sin duda superior a las demás novelas. Todavía estoy pagando los gastos de imprenta y no hay seguridad, que me serán reembolsados».

Galdós había otorgado algún tipo de autorización verbal o escrita a otra persona a quien se identifica bajo el nombre "Wilhelmina». Es curioso observar que no se trata de Emilie Reichel, la traductora de Doña Perfecta, en edición de Pierson's. Por lo tanto, es justificado y acertado confirmar que hubo una traducción anterior de Doña Perfecta, en algún periódico, realizada por esta señora Wilhelmina, de la que no tenemos más datos, y que no aparece en los listados bibliográficos. Tal vez, porque estas referencias bibliográficas se refieren a libros y no a periódicos. Eso nos lleva a la hipótesis de que, efectivamente, se tradujo con anterioridad en prensa.

En cualquier caso, Hartmann no culpa de esta situación a Galdós y le dice:

«Pero en lo que respecta al desastre con Doña Perfecta comprendo bien, que Ud. no tiene culpa en eso, y estoy lejos de cargar a Ud. con un mínimo de responsabilidad. Ud. no ha podido proceder de otro modo que de el, en que ha procedidom. ${ }^{4}$

Hasta aquí llega la cuestión de Doña Perfecta entre Galdós y Hartmann; este asunto ya no es tema de su relación epistolar que concluye en 1880, aunque diez años después se retoma la relación entre los dos y aparecen otras cartas, pero ya no tratan esta cuestión. La cosa podría haber parado en esa fecha, pero lejos de tranquilizarse, don Benito escribe a otra persona con la esperanza de averiguar algo más sobre la traducción de su novela. El receptor de esta carta es un tal O. Bartning, quien responde a la misiva del escritor, un 6 de julio de 1892 (carta número 3):

4 Hemos respetado la sintaxis original de la cita, a pesar de los errores. 
«Muy apreciable señor:

He tenido el gusto de recibir la que con fecha 6 del mes pasado se ha servido Ud. dirigirme. En seguida traté de conseguir la traducción de la Doña Perfecta, la cual está hecha por E. Reichel, se intitula "única traducción autorizada” y apareció el año de 1886 en casa de E. Pierson's, Dresden y Leipzig”.

De entrada, ya se plantea la pregunta de quién era ese Bartning con el que Galdós parece que mantenía una relación cordial. Este señor comenta que ha leído la traducción realizada por la traductora, Emilie Reichel, y dice:

«Siento infinito decir a Ud., que la tal traducción es enteramente indigna de su original. No comprendo, como semejante obra haya podido darse a la prensa, pero sí comprendo, como es que haya pasado en Alemania completamente desapercibida, porque pretendo sin exagerar, que ninguna persona de sentido común podrá leer cuatro páginas de la llamada traducción sin tirar el libro con disgusto».

Creemos oportuno abrir un breve paréntesis para explicar que esta carta arroja luz sobre lo que nosotros consideramos una confusión en los datos bibliográficos aportados hasta la fecha. Es un contemporáneo de Galdós quien, sin ningún género de dudas, nos informa de quién es la traductora, E. Reichel (no J. Reichel), en qué editorial se publica, Pierson's (no Biersons como aparece a veces transcrita en los listados bibliográficos de Hernández Suárez), además del año de publicación, 1886.

Es curioso que mencione la mala calidad y que afirme que ha pasado «completamente desapercibida». Decimos que es curioso, porque a pesar de la mala traducción, Doña Perfecta tuvo dos ediciones, las dos con la misma editorial y la misma traductora, con diecisiete años de diferencia entre la primera edición (1886) y la segunda (1903). Es la única obra de Galdós que experimenta este éxito editorial en vida de Galdós; posteriormente, se publica en otras cuatro ocasiones, ${ }^{5}$ sumando un total de seis ediciones hasta la fecha. Es, por lo tanto, la obra más traducida y publicada en alemán, a pesar de las críticas vertidas sobre su mala calidad desde el momento de su primera publicación.

De la carta resulta interesante observar que el remitente se confunde y habla de la traductora como si se tratara de un hombre y no de una mujer:

«Me abstengo de demostrar lo incorrecto y pueril del estilo del $\underline{\text { Sr}}$. Reichel, porque para ello tendría que copiar casi el libro entero, y mas fácil será que Ud. consulte alguna persona en España que entienda igualmente bien los dos idiomas. Me limito pues a dar algunos ejemplos de cómo el mencionado escritor no solo no comprende el castellano, sino procede con la mayor ligereza, sustituyendo por frases y voces cuyo sentido ignora, disparates de su propia invención, sin siquiera recurrir al diccionario».

5 Doña Perfecta (1963), traducida por Egon Hartmann, y publicada por la editorial Aufbau Verlag, en Múnich; Doña Perfecta (1974), publicada por la editorial Aufbau Verlag, en Múnich; Doña Perfecta (1989), traducida por Horst Weich, y publicada por la editorial Winkler Verlag, en Múnich; Doña Perfecta (1992), publicada por la editorial Fischer Verlag, en Frankfurt am Main. 
Son críticas que Bartning ilustra con un estilo muy didáctico, pues añade: «pongo primero el texto original y al lado la retraducción al español de lo que dice la traducción alemana». Aporta diecisiete ejemplos, que nosotros hemos contrastado con la versión publicada en Alemania en 1903, es decir, con la segunda edición de Doña Perfecta, que se encuentra en la Staatsbibliothek en Berlín y se puede consultar en línea. Los errores que menciona se trasladan sin corregir, diecisiete años más tarde, a la segunda edición, así lo hemos constatado nosotros.

La carta a Bartning es de 1892, es decir, ya habían transcurrido seis años desde la aparición de la traducción (1886), y a don Benito el tema le seguía preocupando. ¿A qué se debe este retraso entre la publicación y la carta de Galdós a Bartning? No lo sabemos, pero resulta obvio que a Galdós algo no le encajaba en el tema de la versión alemana de Doña Perfecta.

Como muestra del enfado de Bartning aportamos uno de los errores contenidos en la versión de Emilie Reichel, y que el remitente explica con suma indignación y muy gráficamente a Galdós, en un estilo apasionado en el que incluye algunas palabras italianizantes:
«Para no aburrir a Ud. mas, no sigo adelante con esta litania [sic], mas no puedo negarme el gusto de sacar a luz como finale [sic], la siguiente ocurren- cia: pág. 99. Se habla de "otros muchos colindantes que reclamaban". La palabra colindante era chino para el sr. traductor, el diccionario no lo tenía a mano o le daba flojera para hojearlo, pero conociendo bien la palabra "col", sin duda por recordarse del choucroute, traduce con mucho garbo "Koblbauern", quiere decir: jcultivadores de col! Ignoro, si más adelante se en- contrarán otras sublimidades por el estilo, porque aquí se me acabo la pa- ciencia y temo, que igual cosa le pasará a Ud., por cuyo motivo pongo fin a esta ya tan larga carta, rogándole a Ud. disimule que le haya molestado tanto».

Cabe preguntarse cómo es que Galdós escribe a Bartning, de qué lo conoce o quien lo ha recomendado, y cómo es que en la misma carta Bartning, que se ofrece para ayudar en futuros proyectos de traducción en Alemania, le dice que puede pedir informes sobre su persona:

«En Santander, donde se halla Ud. actualmente, vive el Sr Don Francisco Pérez Bustamante, con el cual he tenido el gusto y la honra de ser asociado varios años en el Puerto de Mazatlán, República Mejicana. No dudo que si acaso le conoce Ud., tendrá la bondad de darle los informes que Ud. deseare respecto de mi».

Este último comentario parece contradictorio, pues es Galdós quien se ha dirigido a él, de modo que debe manejar referencias o información sobre Bartning, pues le escribe sin conocerle personalmente. Esta es la única misiva que se conserva de este remitente sobre el tema de Doña Perfecta y, como decimos, no se conserva ninguna de Emilie Reichel. 


\subsection{Cartas de interesados en traducir Doña Perfecta}

Aparte de las cartas de Hartmann y Bartning sobre la traducción, se conservan otras cinco cartas que mencionan el interés por traducir la obra. Si ordenamos cronológicamente las solicitudes o propuestas para traducir este título, nos encontramos con la carta remitida por Elisabeth Feschke, el 30 de abril de 1884 (carta número 31), escrita en francés. Esta dama le comenta que ha leído su novela Doña Perfecta en la Revue Internationale, de Monsieur de Gubernatis y que desea traducirla (véase 2.16). En esta carta se pone de manifiesto que las novelas de Galdós circulaban no solo en formato libro, sino en gacetas, revistas literarias y folletines, en Europa, en este caso en Francia. ${ }^{6}$ Galdós no hace ninguna anotación en la carta.

Siguiendo este orden cronológico, nos encontramos con la siguiente carta escrita por Eugéne von Buddenbrock, el 22 de marzo de 1891 (carta número 15), también en francés. Solicita traducir Doña Perfecta para una obra de caridad y le solicita la autorización a don Benito. En esta carta, el escritor sí anota a lápiz: «contestada 29 de marzo». No sabemos en qué sentido fue la respuesta, pero hay que hacer notar que en la fecha en la que se recibe la carta de Buddenbrock, Doña Perfecta ya hacía cinco años que se había traducido y publicado en Alemania. Galdós le otorgará, más adelante, los derechos de traducción de otra de sus novelas. Buddenbrock será el traductor de El amigo Manso.

La última propuesta de traducción de Doña Perfecta nos lleva a la carta redactada en español por Franziska Schröder y fechada el 4 de mayo de 1901 (carta número 143). Esta persona le pide encarecidamente que le permita traducir la novela:
«[...] tenga la bondad de concederme permiso de traducir su obra Doña Perfecta, por la cual me intereso mucho, en el idioma alemán y de publicarla en un periódico o en forma de libro. Como deberé dar una subvención considerable a las costas del imprimir, ruego a Ud. adictamente [sic] por el favor de darme el permiso gratis o contra fútil compensación».

Esta carta está tachada de arriba abajo con lápiz rojo, supuestamente por don Benito, pero hemos querido destacar con nuestro subrayado de nuevo lo popular que resultaba publicar en periódicos.

\subsection{El amigo Manso}

El amigo Manso se publica en España en 1882. Solo constan dos cartas interesándose por la traducción de El amigo Manso, en Alemania, y las dos son de su traductor final, Eugène von Buddenbrock, quien escribe la primera el 15 de junio de 1891 (carta número 17), en francés. En la carta el autor hace referencia a otra que envía, con fecha 9 de mayo y que, al parecer, Galdós no ha recibido, por eso le escribe de nuevo, para solicitarle los derechos de traducción de El amigo Manso. Don Benito anota a lápiz: «autorizado,

6 Doña Perfecta se publica en la Revue Internationale el 25.08.1884 (López Jiménez 1995:159), en francés.

7 Amigo Manso (1894), traducido por Eugéne von Buddenbrock, editorial Verlag von Karl Siegismund, en Berlín. Sobre el particular consúltese Ramírez Jáimez 1993. 
contestada el 20 de junio 1891». En la siguiente carta, de fecha 9 de diciembre de 1891 (carta número 19), Eugène von Buddenbrock solicita más tiempo, concretamente, hasta el 31 de diciembre de 1893, para la traducción que se publica, al fin, en 1894, por la editorial Verlag von Karl Siegismund.

\subsection{Episodios nacionales}

Para la traducción de los Episodios nacionales, sin concretar título, se postulan al menos dos personas. El primer interesado es una persona que firma como Heroldo, que remite carta un 10 de enero de 1892 (carta número 73), redactada en español. En realidad, esta carta no parece dirigida directamente al escritor, pues el autor comenta que «ya hace algunos meses que me dirigí al Sr. D. B. Pérez Galdós notificándole la intención de traducir sus Episodios nacionales». Como quiera que no recibió respuesta pide la mediación del destinatario, cuyo nombre desconocemos. Meses más tarde vuelve a escribir, esta vez directamente a don Benito.

En esta segunda carta, fechada un 6 de septiembre de 1892 (carta número 75), y redactada en español el autor se define como literato. "Tengo la intención de traducir algunas obras de autores españoles modernos y, como su nombre de Ud. con toda razón está muy estimado entre los alemanes [...] quisiera dar principio a traducir sus Episodios nacionales».

A continuación solicita permiso para traducirlos, apostillando: «No hay cuanto sepa convenio alguno internacional entre nuestros países respectivos relativo a la literatura, pero no obstante no puedo hallar justo el aprovecharse de la propiedad espiritual ajena sin permiso de la parte del autor, bien que no lo sea defendido por ley». No nos consta anotación o respuesta del escritor.

En cuanto a la siguiente persona interesada en los Episodios nacionales, se trata de alguien que firma como Jessen o Tessen, pues el apellido no se lee muy bien, y dice: «Le pido a Ud. el permiso de traducir alguno de sus interesantísimos Episodios nacionales para publicarlos en un periódico alemán». La carta está fechada el 20 de enero de 1887 (carta número 83) y contiene una anotación a lápiz por parte de Galdós que pone lo siguiente: «autorización por un año para Episodios, 1 de marzo de 1887». Jessen o Tessen obtiene el permiso de Galdós para traducir alguno de los Episodios en un periódico, hasta 1 de marzo de 1888. No sabemos si se materializó la traducción. En cualquier caso, se incide de nuevo en la publicación en prensa, asunto al que se debería dedicar una investigación exhaustiva.

Otro de los corresponsales, se interesa, concretamente, por Aita Tettauen. Se trata de F. Steinitz, que escribe un 6 de junio de 1905 (carta número 82), en español, solicitando permiso para traducirlo. No consta respuesta del escritor, ni anotación alguna.

\subsection{Electra}

Se estrena en enero de 1901 y el interés que despierta Electra en Alemania se ve reflejado en tres cartas. La primera de ellas la firma Else Otten (también puede ser Ossen), el 7 de marzo de 1901 (carta número 113), y está escrita en francés. Es una misiva que no parece dirigida directamente al escritor, y en ella la autora se interesa por los derechos 
de traducción y representación de la obra. También menciona de pasada haber recibido un ejemplar de Nazarín.

La siguiente es de Arturo Pollini, está fechada un 2 de mayo de 1901 (carta número 121) y está escrita en un perfecto español. Conocedor del éxito que la obra había tenido en España, le comenta que él en compañía de otra persona ya la habían traducido. Le presentan la traducción al Barón de Berger, director de uno de los teatros de primera fila, el Deutsches Schauspielhaus en Hamburgo, y comenta que han firmado contrato con fecha 24 de abril para su representación inmediata. Queda a lo que disponga Galdós en cuanto a condiciones contractuales. Esta traducción de Electra por Pollini es otra desconocida. No sabemos si se representó al final en el teatro mencionado.

Y la última de las cartas, la firma Eberhard König, con fecha 25 de junio de 1904 (carta número 85) y también está escrita en español. Se interesa por Electra y se presenta a sí mismo diciendo «soy un autor dramático, y tengo relaciones muy estrechas con algunos teatros de Alemania y sobre todo de Berlín». Solicita permiso para traducir. No consta respuesta de Galdós.

\subsection{La de San Quintín}

Se publica en España en 1894. Sobre la traducción y representación de esta obra de teatro, existe una abundante correspondencia entre Sigmund Lautenburg, director del Residenz Theater de Berlín, y Galdós, que merece la pena detallar. Incluso se conserva otra carta, del Consulado de España en Berlín, fechada el 23 de febrero de 1894 (carta número 23), que da referencias sobre la respetabilidad y prestigio del señor Lautenburg y de su teatro, datos de la persona y del teatro, de los que el consulado informa a Galdós, a petición del propio Lautenburg. Se concreta realizar una traducción y representar la obra. Se conserva el contrato firmado entre las partes.

Comienza esta correspondencia, el 27 de febrero de 1894 (carta número 89), y Lautenburg escribe en francés a Galdós agradeciéndole que le haya enviado un ejemplar de la obra. Comenta que la ha leído con interés y que desea representarla en su teatro. A continuación detalla cuestiones relativas a los pagos por derechos de representación y se despide encantado de poder dar a conocer en Alemania a un autor del genio de Galdós. El escritor anota a lápiz en la propia carta: «aceptadas proposiciones, 9 de marzo de 1894».

Luego se suceden tres cartas del secretario de Lautenburg, con diferentes asuntos relativos al contrato: 9 de abril de 1894 (carta número 91)]; 16 de mayo de 1894 (carta número 94); 4 de julio de 1894 (carta número 95), y la última, fechada el 16 de julio de 1894 (carta número 99), es la que contiene el contrato redactado en francés y firmado por Lautenburg, que el secretario envía, diligentemente, a Galdós. Lautenburg vuelve a escribir con fecha 29 de agosto de 1894 (carta número 101), en francés. Se entera del estreno en Madrid de otra obra de Galdós y solicita los derechos para su traducción. Galdós anota en la propia carta: «contestada». No sabemos la fecha.

Casi un año más tarde, se retoma la correspondencia. Se trata de la carta fechada el 15 de septiembre de 1895 (carta número 103), redactada, curiosamente, en español. Las anteriores, todas, fueron en francés. En esta carta, Lautenburg le informa de que debido a la mala calidad de la traducción no ha sido posible estrenar la obra en la fecha prevista: 
«Solamente tengo que observar que Ud. ha sido inducido en error; a principios de este año escribí a Ud. para decirle que la obra había sido desgraciadamente tan mal traducida, que en su propio interés tuve que desistir de representarla hasta que se hiciera una traducción mejor, la que no pudo llevarse a cabo sino en el corriente del verano".

Pero ya cuenta con otra traducción y le informa de que se estrenará en invierno. ¿Quién hizo esa traducción? Existe una carta contenida en este archivo, en la que creemos haber identificado al autor de esa «mala traducción»: el señor Levin (carta número 107).

Transcurre otro ańo, y el 6 de septiembre de 1896 (carta número 105), Lautenburg escribe de nuevo en español. Parece contestar a una carta anterior del escritor en el que este le solicitaba anular el contrato:

\begin{abstract}
«El año pasado me pidió Usted que anulara el contrato que habíamos hecho relativamente a la Duquesa de San Quintín. El 15 de septiembre de 1895 le contesté a Ud. que por falta de un buen traductor no había podido hacer representar todavía su drama pero que esperaba poderlo representar este invierno. Desgraciadamente no ha sido posible [...] y yo por mi parte he hecho tantos esfuerzos para conseguir una buena traducción sin poderlo alcanzar y desespero lograrlo, no puedo más que pedir ahora yo mismo a Usted considere como nulo el contrato que habíamos hecho».
\end{abstract}

Aquí se acaba la correspondencia entre Lautenburg y Galdós.

El autor de la siguiente carta es una persona que firma como Levin. Escribe el 21 de mayo de 1894 (carta número 107), en español. Esta carta contiene tal vez la clave para identificar al responsable de la «mala traducción» de La de San Quintín, pues en ella podemos leer: «Ahora se pone la ocasión de acercarme a Ud. en medio [quiere decir gracias a la mediación de] el Sr. Lautenburg, director del teatro nuevo me ha transportado [hecho llegar] la traducción de su insigne drama La de San Quintin ${ }^{8} »$. Solicita permiso para traducirla y le pide a Galdós un ejemplar. El escritor, anota a lápiz, según su costumbre en la propia carta: «enviada La de San Quintin».

Si nos fijamos en la secuencia de fechas, esta carta se sitúa justo antes del envío del contrato firmado y enviado en el mes de julio, entre el director del teatro y el propio Galdós. Esta carta es la que nos hace suponer que el primer traductor y responsable de la «mala traducción» fue el Sr. Levin. Con estas cartas, no parece que fructificara la representación de La de San Quintín en Berlín, al menos en esa ocasión.

\title{
2.7. El abuelo
}

El éxito obtenido por la representación de El abuelo en España, estrenada el 14 de febrero de 1904, tuvo una enorme repercusión en Alemania, a la luz de las cartas recibidas. Pone de relieve, aún más, el prestigio y el renombre de los que gozaba el autor.

El 16 de febrero de 1904 (carta número 13), una persona llamada Alfred Bricyer se dirige a Galdós en español. Le cuenta que se ha enterado por el periódico del éxito de

8 Hemos respetado la literalidad de la cita con sus errores sintácticos y de léxico. 
una obra suya en el Teatro Español, y solicita derechos de traducción y de representación. Se presenta él mismo como autor. No menciona la obra a la que se refiere, pero suponemos que se trata de El abuelo a juzgar por las fechas.

Otra persona le escribe por el mismo asunto, con fecha 24 de febrero de 1904 (carta número 111), en español. Se trata de R. Näcke. Le felicita por el éxito obtenido por $E l$ abuelo y solicita autorización para traducirlo.

La siguiente carta la firma Joseph Mayer, un 28 de febrero de 1904 (carta número 109), y la dirige a Galdós en español. Se presenta como traductor de la obra Las Doloras de Campoamor, le felicita por el éxito obtenido con El abuelo y solicita el envío de un ejemplar y autorización para traducirla.

El mismo día, le escribe otra persona que firma como F. Steinitz. Lo hace también en español (carta número 151) y le solicita autorización para traducir la obra El abuelo. El escritor anota a lápiz la siguiente respuesta: «He concedido ya la traducción de $E l$ abuelo a D. Julio Dorrita o Zorrita [apellido ilegible]».

El 2 de abril de 1904 (carta número 167), le escribe Federico Vollmer, en español. Le felicita por el éxito de El abuelo del que informan los periódicos alemanes, y solicita autorización para traducirlo. También le informa de que ha traducido La loca de la casa y que está haciendo gestiones ante un importante teatro de la ciudad, para poder representarla. El escritor anota a lápiz: "Agradezco mucho su felicitación por El abuelo y pongo en su conocimiento que a poco de ser estrenada dicha obra en Madrid autoricé para su traducción al sr. Julio Zorrita o Dorrita [apellido difícil de leer] residente en Madrid». Son dos las veces en que leemos el nombre de un posible traductor al alemán de El abuelo. No sabemos si se tradujo, es una cuestión que, como en casos anteriores, habrá que estar a la espera de nuevas investigaciones.

La última de las cartas que se reciben con motivo del éxito de El abuelo, viene de la mano de W.Th. Stirrüp [apellido no muy claro en la carta]. Está datada el 13 de abril de 1904 (carta número 171), y redactada en español. Le felicita por el éxito obtenido por El abuelo del que se ha enterado por la prensa y se ofrece para traducirlo, desinteresadamente.

\subsection{La de Bringas y Tormento}

La de Bringas y Tormento se publicaron en 1884. Paul Ewald remite un total de dos cartas a don Benito. En la primera de ellas, fechada el 8 de octubre de 1884 (carta número 115), escrita en francés, dice haber leído Doña Perfecta y las críticas a sus novelas Tormento y La de Bringas. Solicita permiso para traducir La de Bringas. Se produce una curiosidad, y es que esta persona en su carta nos informa de que es él quien ha sugerido a Galdós que autorice a la señora Feschke para la traducción de Doña Perfecta. Esta señora le había escrito el 30 de abril de 1884, se corresponde con la carta número 31 (epígrafe 2.2.).

El escritor anota: «12 de noviembre de 1884 le contesto autorizándole para traducir Tormento y La de Bringas y fijándole un año para la duración de esta autorización». Interesa recalcar, de nuevo, la repercusión que las obras de Galdós tenían en Alemania, de las mismas. 
En la segunda y última carta de Paul Ewald, fechada el 12 de enero de 1885 (carta número 119) también en francés, se disculpa por no haber respondido antes, y el motivo no es otro que una enfermedad, pues está afectado de una neurastenia y le anuncia que a mediados de febrero puede que se publiquen Tormento y la de Bringas. Nos preguntamos si verían la luz o no, pues esta es la última carta de Paul Ewald. Aquí tenemos de nuevo el dato de que Galdós concedió derechos de traducción de los que desconocemos si vieron la luz como publicaciones o no.

\subsection{Marianela}

Marianela se publica en 1878, en Espańa. Según los datos que hemos manejado en la Bibliografía (Hernández Suárez 1972), Marianela, se tradujo al alemán en 1888, por la señora Emilie Plücher. Nosotros no hemos podido encontrar la pista de la traductora ni de la traducción. En cambio, existen datos que pueden confirmar que existió al menos otro posible traductor.

En concreto, en la carta fechada el 12 de noviembre de 1885 (carta número 47), firmada por la editorial Greiner (Ludwig Greiner) y escrita en francés:

«Il y a quelque temps Mr. Arthur Rochl me présenté une traduction d'un de vos Romans autorisé, que je ne pouvais pas encore me decider a recepter. Mais j'ai devant moi le manuscrit de Marianela que je veux publie, si vous y donner a Mr. A. Rochl votre autorisation».

Este traductor, Rochl, le informa sobre la existencia de la novela Gloria, y el seńor Greiner se muestra también interesado en publicarla, si aún no se ha publicado en alemán. Anotación a lápiz del escritor: "contesto el 19 de noviembre autorizando para traducir Marianela al alemán». Es decir, Galdós autoriza a Arthur Rochl para la traducción de Marianela, en 1885. Los datos bibliográficos indican que fue traducida en 1888, por Emilia Plücher, de modo que esta traducción, de haberse materializado, sería anterior, al menos en dos años. Además, se conserva en el archivo la tarjeta de visita del señor Rochl.

La siguiente carta la remite Hans Robrahn, quien escribe un 6 de junio de 1895 (carta número 125), en espańol, solicitando permiso para traducir Marianela. No consta respuesta de Galdós ni anotación alguna.

La última de las cartas que se conserva en este archivo, y que apunta a una posible traducción posterior de Marianela, es la que remite el 20 de noviembre de 1903 (carta número 9), Felix Bloch, y está escrita en francés. El autor responde a una carta anterior de don Benito, concretamente, del 16 de septiembre de 1903. Se lee que el traductor contratado para traducir Marianela, acepta las condiciones. Ignoramos si se trataba de un hombre o de una mujer. La editorial pide a Galdós que le conceda los derechos para Alemania, Austria y, si a Galdós le parece bien, añadiría Hungría. De nuevo nos asalta la duda de si existen otras versiones de Marianela, aun por descubrir. 


\subsection{Gloria}

El autor la publica en 1877. Se conservan ocho cartas entre el escritor y el traductor, August Hartmann. La primera de ellas está fechada el 12 de marzo de 1879 (carta número 51) está redactada en español y comienza así:

«Muy señor mío y de mi mayor consideración:

He recibido su grata del 26 de Febrero y con mucho gusto acepto las generosas condiciones que Ud. me pone por la traducción de la Gloria en alemán, que, si Dios me deja salud, será publicada mucho antes del plazo que Ud. fija (26 Febrero 1880)».

Como suele ser ya habitual, detectamos que debió existir una correspondencia anterior que no ha llegado a nuestras manos, pues claramente se lee que Galdós le escribe el 12 de marzo para fijar, definitivamente, las condiciones de los derechos de traducción. Como siempre, el escritor fija el plazo de un año, algo que se repite en todas las cartas anteriores con traductores. La relación entre Hartmann y él, debió ser muy anterior, pues el traductor continúa diciendo:

«El primer tomo ya está en borrador. Es de esperar que el resultado salga satisfactorio y que se ponga en condición de poder agradecer a Ud. su obsequio no solo con palabras. Como tengo mucho gusto en traducir más novelas de Ud., conservo siempre la esperanza de que al verse satisfecho de mi trabajo Ud. me confíe más una u otras».

Resulta complicado elucubrar a qué «obsequio» se podría estará refiriendo Hartmann, que según descubrimos en las cartas es una persona protocolaria y afable, además de resultar entrañable. Tal vez, esté aludiendo a que traducir la obra de Galdós en sí mismo ya es un obsequio, pero como decimos, resulta aventurado lanzar hipótesis sobre el sentido. En cualquier caso, está avanzada la traducción, pues el primer tomo ya está traducido, si bien como borrador a falta de correcciones. Le asaltan dudas con relación a los nombres propios y su traducción, y vamos a extraer algunos ejemplos:

«Los nombres propios de la novela los he dejado en español, así como es costumbre, pero se ofrece una dificultad respecto al reverendo obispo ¡Angel tiene en alemán el sentido de un gancho de pescar! Conservarse dicho nombre sería pues ridiculizar la dignísima figura de este santo varón. Le propongo a V. substituir el español antiguo «Angelo» o dar a este prelado otro nombre cualquiera. V. lo decidirá».

Este asunto fue tratado brevemente por la investigadora Ramírez Jáimez (1993: 190). La segunda carta que se conserva, está fechada el 11 de junio de 1879. Está escrita desde Endenich, población cercana a Bonn. Este será el domicilio para los próximos años del traductor. Comentamos este aspecto, porque a lo largo de la correspondencia, Hartmann cambiará varias veces de domicilio y se lo comunicará a Galdós. Gracias a esta tarjeta postal, nos enteramos de que Hartmann ha vivido hasta la fecha en Oviedo: 
«La presente tarjeta sirve para anunciar a Ud. que he dejado a Oviedo y a

España tomando mi residencia en mi país natal».

Pues bien, en esta tarjeta agradece la respuesta de don Benito, fechada el 12 de abril, de cuyo contenido queda enterado. Suponemos que se trata de la respuesta a sus dudas sobre los nombres propios y le comunica que ha trasladado su residencia a Alemania, por lo que la traducción se ha retrasado algo. Informa que, aún así, ya va por el capítulo $\mathrm{XX}$ del segundo tomo.

En la tercera carta, fechada el 30 de septiembre de 1879, Hartmann, agradece la respuesta de don Benito, fechada el 28 de julio. En ella don Benito le instruye para que no ponga «Doña» delante del nombre en el título. El traductor, al parecer, no había captado el sentido alegórico del título, y agradece al escritor la lección que le ha dado.

Informa al escritor de que ha encontrado editor "pero bajo condiciones poco agradables: es decir debo adelantar la mitad de los gastos y participo con la mitad al beneficio o al "déficit" si lo hubiera». Informa de que el primer tomo ya está en prensa. Está poniendo todo su empeño para que pueda estar en las librerías por Navidad, pues es cuando más se vende, como regalo. También informa de que «la primera edición por insistencia del editor será poco numerosa (muy pequeña) y en consecuencia de esto el precio del libro bastante elevado, aunque ni por lejos alcanzará al insensato precio de la versión inglesa». La carta no tiene desperdicio, pues nos informa de que ha adquirido la versión inglesa y que la ha entregado a un amigo literato para su cotejo. Este le da su opinión certera de que la versión alemana es muy superior a la inglesa, que considera más bien superficial. Este literato también enmienda algunos pasajes de la traducción de su amigo Hartmann.

El editor le pide que le mande alguna crítica favorable que se haya publicado en España de la novela Gloria. El traductor le comenta que él se encargará de traducirla y que devolverá el original a Galdós. Se refiere a su carta del 9 de julio en la que manifestaba al escritor, que había encontrado algunos fallos o «imperfectos» como los nombra él, «que merecían ser enmendados en su tercera edición de la novela». Esta carta no existe en el archivo. Al parecer Galdós no le contesta ni hace alusión alguna a dichos comentarios, no obstante en esta carta, Hartmann retoma el asunto y desglosa una serie de ellos pormenorizando los detalles y defectos encontrados. Se está refiriendo a errores de imprenta o de redacción en la versión española, por parte de Galdós. Le dice que está mal escribir «ininteligible» y debe decir «inteligible, que no debe escribir «aplacar», sino «aplicar». El traductor corrige el español de don Benito, para evitarle los defectos en la tercera edición de la novela. Al parecer, Galdós no tuvo en cuenta los consejos de su traductor, según se deduce de la carta del traductor. Nos limitamos a insertar la introducción al extenso listado: «No me ha contestado a dicha pregunta; pero suponiendo que eso no fue nada mas que por olvido, no hesito en manifestar a Ud. los que más estorban, ¡seguro que Ud. no me juzgue por eso poco modesto!».

En total representan unas tres páginas en las que Hartmann relaciona, uno por uno, lo que él considera que son errores de don Benito y que se deben corregir. Por lo prolijo de los ejemplos aportados, se hace imposible reflejarlos aquí, pero resultan muy curiosos y simpáticos. La relación con Hartmann debía ser muy fluida y cordial, pues como hemos visto Galdós le hace algún tipo de encargo de gestión con relación la traducción 
de la novela Doña Perfecta, que hemos tratado con anterioridad y que obviaremos aquí, pues solo extractaremos lo relativo a la traducción de Gloria.

En la cuarta carta, fechada el 15 de diciembre de 1879 (carta número 59), le comunica que Gloria está a la venta desde hace ocho días tanto en Alemania como en Austria. Responde a la carta escrita por Galdós el 24 de noviembre. Le informa de que se habla de su traducción de una manera muy «lisongera [sic], mientras crítica en contra no ha aparecido ninguna todavía. Me alegro muchísimo, que mi trabajo lo menos es recibido con benevolencia, y es de esperar que será recompensado también materialmente». Naturalmente, se refiere a que recibirá su $50 \%$ de beneficio sobre la venta. Dice que ha encargado al editor, Schleiermacher, nieto del famoso filósofo y teólogo, que remita a don Benito un ejemplar encuadernado y que él, a su vez, le remitirá un ejemplar en bruto. Que le habría encantado remitir dos ejemplares encuadernados, pero que la edición ha sido tan limitada que no puede enviárselos. Si don Benito hubiera escrito quince días antes, sí habría sido posible.

Interesa de este traductor el contenido de casi todas sus cartas, pero muy especialmente de esta. Detalla las condiciones en las que trabajaba un traductor en aquella época e incluso menciona el precio de compra: «En caso de que una librería de Madrid quiera comprar la obra para venderla, deberá pagar al editor el precio estipulado de diez pesetas, el ejemplar bruto, o doce con cinco pesetas el encuadernado». Le afea a don Benito la tardanza que tiene en contestar, pues debido a ello, ha salido un prólogo con algunas inexactitudes, pues esperaban datos del escritor que no llegaron a tiempo para la primera edición, y que por eso ha incluido pasajes enteros de Palacio Valdés: «El librito de D. Armando Palacio Valdés que yo poseía ya en España, me ha dado buenas y claras luces y Ud. verá, que he traducido y puesto en el prólogo una buena porción de su contenido».

Don Benito, en la carta fechada el 24 de noviembre, le propone que traduzca algunas de sus obras. Hartmann contesta encantado que así lo hará, y que empezará con Doña Perfecta. Esta historia ya la hemos tratado anteriormente en el epígrafe dedicado a la traducción de esa novela. Continúa Hartmann, solicitando aclaración sobre un título que Galdós le sugiere también que traduzca, pero que, lamentablemente, no entiende la letra del escritor. En la carta escribe "La familia de...». Evidentemente, se trata de $L a$ familia de León Roch. Como curiosidad Hartmann propone a Galdós un traductor al inglés para ambas novelas, Doña Perfecta y La familia de León Roch, un traductor muy capaz: su propia esposa, "pues mi señora es inglesa y capacísima con la pluma, además sabe tanto español como yo. ¿Qué le parece? ¿No está Ud. comprometido ya con otro?».

Aquellas relaciones fluidas y cordiales no se vieron premiadas con un conocimiento personal.

Por eso Hartmann le envía una foto suya a Galdós y le pide que a vuelta de correo y previo pago anticipado, le mande una de su persona. La foto se conserva en el archivo de la Casa-Museo es la carta que se corresponde con el número 71 del PDF. La dedicatoria tiene fecha del 15 de diciembre de 1879 y dice así: «15.xii. 1879. Dr. August Hartmann el traductor al autor de la Gloria, D. Benito Pérez Galdós».

La quinta carta está fechada el 24 de enero de 1880 y Hartmann agradece la carta del escritor, fechada el 1 de enero. En dicha carta, al parecer, don Benito felicitaba al traductor. Él le responde con modestia, diciendo que ha hecho «lo que se podía. Hartmann continúa su misiva diciendo al escritor que está a la espera del envío de libros que le pro- 
metió. Termina rogándole que «no olvide enviarme también su retrato». En esta carta se vuelve a hacer mención al tema de la traducción de Doña Perfecta.

La sexta carta está fechada el 12 de agosto de 1880 y está enteramente dedicada al tema de la traducción de Doña Perfecta, carta que hemos tratado en profundidad anteriormente. Pero menciona de pasada que la venta de la traducción de Gloria no ha ido como esperaban: "Así me pasa con la Gloria, la mejor de lo que Ud. ha escrito y sin duda superior a las demás novelas. Todavía estoy pagando los gastos de imprenta y no hay seguridad, que me serán reembolsados». Aquí se ven, claramente, las duras condiciones que imperaban en el siglo XIX para traducir y publicar una obra. Era el traductor el que corría con los gastos de imprenta por lo que se convertía en la práctica en coeditor.

En la carta séptima, fechada el 12 de diciembre de 1880, Hartmann confirma el contenido de su carta del 12 de agosto anterior. Tal y como comentábamos, resulta que el escritor ha tenido que sufragar los gastos de imprenta de la primera edición de Gloria y comenta: «En vez de ganar algo con la Gloria he efectivamente perdido unos 2000 Reichsmark en este negocio, no siendo vendible el resto de los ejemplares, que aun cuenta por centenares».

Ante estas penosas circunstancias para la economía del traductor, Hartmann ve los cielos abiertos, porque un editor húngaro, Maurice Revai de Budapest, desea publicar Gloria:
«Bajo esta miserable circunstancia y en la necesidad de buscar compensación se me presenta la siguiente idea: El director de un periódico húngaro (Re- genyvilag) tiene ganas de publicar la Gloria en su periódico traduciéndola al idioma húngaro. Como me consta que el no entiende espańol, se servirá indudablemente de la traducción mía alemana, transformándola a una hún- gara, pues perfectamente el sabe el idioma alemán. Es probable que él se dirigirá a V. rogándole el permiso de traductor, porque me ha pedido a par- ticipar las señas de V.».

Le propone a Galdós que le pida 2000 marcos, que se repartirían al $50 \%$, y le dicta el texto para que Galdós lo transcriba en su respuesta al editor húngaro: «[...] dé el permiso bajo la condición que antes de principiar la publicación se entienda con el sr. Augusto Hartmann, el autor de la edición alemana, cuanto respecto a la remuneración a pagar, pues es Hartmann a quien he encargado con esos asuntos». Encarece a Galdós para que conteste cuanto antes, tanto a Hartmann como al señor Revai, pues es consciente de que el editor húngaro desea publicar en enero de 1881.

De pronto, la correspondencia cesa, y Hartmann vuelve a escribirle, pero diez ańos más tarde, en 1890. Se trata de la carta octava, fechada el 15 de mayo de 1890. En esta carta, Hartmann comunica que ha cambiado de domicilio y que se ha trasladado a Pforzheim, en la Selva Negra. Y le hace mención a los años transcurridos desde el último contacto epistolar entre ambos: «Muy señor mío y distinguido amigo: Habrá diez años que está parada nuestra correspondencia». Hace mención a que no está tan dedicado a temas literarios, sino más bien científicos y que se está cuidando la salud. No obstante, sigue ligado de alguna forma a la literatura, porque forma parte de un círculo literario y su campo es la literatura espańola. 
Le comunica que ha decidido hablar sobre las novelas de Galdós que tan bien conoce, y le pide que le aporte algunos datos para desempeñar mejor la tarea de divulgación de su literatura. En concreto le solicita información sobre las novelas que haya publicado después de La familia de León Roch, y le pregunta «cuáles de ellas siguen el rumbo o sea la tendencia de liberalismo religioso que ha hecho tan simpáticas al lector alemán las anteriores». También le pide datos sobre su biografía para poder incorporarlos a su discurso. Se despide mencionando de nuevo el desastre de la edición de Gloria al alemán: «Lo que Ud. no sentirá menos que yo es que el éxito de mi traducción de su magnífica Gloria ha quedado el mismo de 1880. El editor había puesto el precio demasiado alto». Este asunto aparecerá, indirectamente, con relación a la traducción de Misericordia y Nazarín que Galdós propone a Jules Schröder, que trataremos en el siguiente epígrafe. También desmiente el dato bibliográfico, que se maneja hasta la fecha, que otorga a Gloria dos ediciones, cuando, como se ve la primera fue un fracaso y diez años después el traductor se lo reconfirma al escritor.

Carta novena y última, fechada un 3 de junio de 1890, solicitando de nuevo los datos que pedía en la carta anterior. Esta parece ser la última carta que se conserva de Hartmann en el archivo de la Casa-Museo.

\subsection{Misericordia y Nazarín}

Nazarín se publica en 1895 y Misericordia, en 1897. Comenzaremos este apartado con las cartas que Jules Schröder remitió a Galdós, pues aportan bastante luz acerca de las condiciones que don Benito imponía a sus traductores, y que eran las habituales en la época. Son un total de cuatro cartas, y la primera de ellas está fechada un 10 de mayo de 1900 (carta número 135), escrita en un perfecto espańol.

Esta persona se presenta al escritor y le dice que ha vivido dieciocho años en las pequeñas Antillas, de las que salió cuando Estados Unidos se las anexionó. Es abogado y secretario del Senado de la ciudad de Bremen. Lleva más de once años viviendo en Alemania, pues es alemán, pero adora la lengua de Cervantes y por puro placer ha terminado la traducción de la novela Gloria. Pregunta si ya ha sido traducida al alemán y de no ser así, le solicita permiso para su publicación.

Galdós le responde el 25 de septiembre. No se conserva la carta, pero se infiere el sentido de la respuesta por la siguiente que le remite Schröder. La situación es la siguiente: Galdós le ha puesto al corriente de que Hartmann había traducido y publicado Gloria, ya en 1880, pero el propio escritor le anima a que se atreva a traducir alguna otra. Esto llena de gozo a Schröder que contesta en su carta del 30 de septiembre de 1900 (carta número 137), a esta proposición de traducir «alguna otra de sus novelas tan reputadas en España y fuera de ella, me impulsa a contestarle en el acto, dándole las gracias por el atentísimo ofrecimiento al cual corresponderé con sumo gusto».

Se inclina por Misericordia y aventura que tal vez el mismo editor de Gloria, el editor Schleiermacher, de Berlín, se anime a esta nueva traducción, aunque sabe de las poco favorables condiciones que aplica este editor: $50 \%$ tanto en beneficios como en pérdidas. Propone firmar la primera traducción bajo un seudónimo, porque al no ser conocido tendría menos riesgo. 
Schröder, en la misma carta de 30 de septiembre, le informa de lo siguiente:

«El camino más usado ahora en este país para publicaciones de este género, que también mejor se retribuyen, es el de la publicación en un periódico en el folletín. Un amigo mío, editor de un periódico muy leído en la Alemania del Norte, se me ha brindado para aceptar traducciones mías, bajo la condición de que las obras no sean demasiado extensas, modernas y de una índole que se presten a leerse por cortos pedazos en un periódico que diariamente se publica».

Le sugiere que envíe una obra más corta que Misericordia para que se pueda traducir y publicar antes, de modo que así él, como traductor, sería reconocido y cuando se terminara de traducir Misericordia y se publicara, llegaría a mayor número de lectores. Galdós anota a lápiz como era su costumbre: [ilegible] Nazarín. El escritor le mandó esa novela, porque así se lee en la siguiente carta de Schröder, fechada el 10 de octubre de 1900 (carta número 139).

En ella agradece la respuesta de Galdós, fechada el 5 de octubre, con el envío de la novela Gloria y de Nazarín, pero, sobre todo, "por las interesantísimas noticias que me da Ud. respecto de las publicaciones de diversas de sus novelas en periódicos franceses». Schröder inquiere si la autorización que ha recibido para Misericordia y Nazarín está completa o le falta algún tipo de detalle o estipulación. Galdós autoriza la traducción de estas dos obras, ya que se lee en la anotación a lápiz lo siguiente: «autorización provisional por un año. 16 de noviembre de 1900».

En la carta, Schröder le informa de que la editorial Schleiermacher, que publicó Gloria, ya no existe:

«He averiguado, que la casa de Schleiermacher ya no existe, pero las imprentas de Pierson's, Dresde, [ilegible], Dresde y Siegismund en Berlín, han publicado obras de Ud. en fecha posterior a la traducción de Gloria y me he puesto en relaciones con dichas casas $[\ldots]$ ».

Pero algo más adelante, en la siguiente carta, intuimos que la relación profesional entre Galdós y el señor Schröder se quiebra, pues el escritor le escribe el 16 de diciembre y le informa de que le retira la autorización que le había otorgado el 5 de octubre para traducir Nazarín. Schröder le contesta el 19 de diciembre de 1900 (carta número 141), desagradablemente sorprendido por la decisión de Galdós. De modo, que Schröder declina continuar con la traducción de la misma. Por si fuera poco, si antes elogiaba la literatura del escritor y que fuera reconocido dentro y fuera de las fronteras de España, ahora le espeta:

«Debo poner en su conocimiento, que por el poco interés, que en la actualidad, lastimosamente, se tiene en este país por la literatura española, todos los diversos editores, con los cuales he correspondido hasta ahora, exigen ver antes de decidirse, si aceptan o rechazan una novela espańola, aun de su ilustrada pluma de Ud., todo el manuscrito de la traducción. Esa circunstancia me obliga a declinar la condición primera y tercera de su atenta carta del 16 del corriente». 
En la carta van aflorando los motivos del desencuentro entre el traductor y el escritor, relacionados con las cláusulas impuestas por el escritor y averiguamos algunos datos curiosos del editor de la novela Gloria, el señor Schleiermacher, que despotrica de la literatura española:

«Pues si ya me parecen altísimos los derechos de autor, que se reserva Ud. en la condición tercera citada — por ejemplo he sabido que la traducción de Gloria, que al principio se vendía al precio de 8,5 marcos, ahora se puede obtener por menos de 2 marcos y el editor de dicha obra me ha escrito, que no le había dejado cuenta esa obra negándose a hacer otro ensayo con novelas espańolas-, de ningún modo puedo aceptar la condición primera. Pues traducir una novela del tamaño de Misericordia dentro del término de un ańo, y eso sin saber si será o no aceptada, pudiendo Ud. revocar la autorización después que yo haya hecho todo el trabajo, es una especulación en la cual no quisiera yo meter mis dedos como Ud. comprenderá».

Y se despide del autor de la siguiente manera: «Pues repito mi mayor sentimiento de no haber podido serle más útil en mi deseo de facilitar a nuestro pueblo algunas de sus ilustradísimas obras escritoriales, me suscribo de Ud. siempre afectuosamente y seguro servidor de usted. Jules Schröder».

\subsection{La loca de la casa}

Se publica en 1893 y se estrena en el Teatro Español. Federico Vollmer, se interesa por la traducción de La loca de la casa y por El abuelo (véase el apartado correspondiente). Escribe el 20 de octubre de 1903 (carta número 163), en español. Agradece la carta por la cual Galdós le marca unas condiciones para la traducción y que el traductor acepta. En la carta no se especifica de qué obra se trata, pero por la secuencia de las cartas posteriores se deduce que se trata de La loca de la casa.

Como decimos, en la siguiente carta de fecha 21 de enero de 1904 (carta número 165), Federico Vollmer le participa que le cabe el placer de haber concluido la traducción de su interesante obra La loca de la casa y que la va a copiar en limpio y presentar a la comisión de un importante teatro de la ciudad. En la carta número 167, fechada el 2 de abril de 1904, le informa de que ha entregado la traducción de la Loca de la casa a un teatro de la ciudad y que en cuanto tenga respuesta se la hará saber a Galdós (véase 2.7.).

Otras dos cartas más inciden sobre el tema de La loca de la casa. Están firmadas por Shillingford, clasificadas, creemos que erróneamente, como alemanas o de traductores alemanes. Se trata de las cartas fechadas el 11 de febrero de 1906 (carta número 145) y la fechada el 22 de marzo de 1906 (carta número 147). Estas dos cartas están escritas en francés y si bien es cierto que versan sobre la puesta en escena de La loca de la casa, hemos llegado a la conclusión de que no se trata de una traducción al alemán. Los datos que nos llevan a esta conclusión están contenidos en la propia carta. El seńor Shillingford escribe desde Alemania, desde Weimar para ser más concretos. Ahora bien, se refiere al estreno de la susodicha obra en Londres, no en Alemania. Le comenta a Galdós que la representación ya no puede ser a fin de año, como era lo pactado, sino más tarde, debido al éxito teatral de la obra The Morals of Marcus. Dado que el éxito de la obra anterior es 
enorme, propone un cambio a la localidad de Margate. Shillingford le habla de las ventajas de dicho cambio, pues permite ajustar la obra antes de llevarla ante el muy exigente público de la metrópolis. Le recuerda que en contrato figuraba la exigencia de que la obra se representara en primer lugar en Londres, y por eso consulta a Galdós.

De todos estos comentarios, salta a la vista que se trata de una traducción o adaptación teatral al inglés de La loca de la casa. Asimismo, el apellido del corresponsal es inglés. Por estos datos, consideramos que figura erróneamente entre la correspondencia sostenida con traductores alemanes, error comprensible puesto que la carta se remite desde Weimar, Alemania.

\subsection{Casandra}

Se publica en 1905 en España. El traductor, Wagler, escribe el 27 de junio de 1906 en español a Galdós (carta número 169). Recibe una amable carta del escritor (20 de junio de 1906), y se decide a responderla. Le expresa su más calurosa admiración por su obra y lo elogia afirmando que junto con Echegaray es el más grande escritor de España. Le explica que un amigo común, Julio Bronté [grafía del apellido no está clara], le había propuesto traducir Casandra y él había aceptado. No obstante, se dirige a Galdós para comunicarle con mucho pesar que no va a poder atender el encargo de traducción, debido a sus múltiples tareas. El señor es concejal de la ciudad de Leipzig, responsable del área de educación y debe lidiar con los presupuestos para escuelas, institutos, etc. Le sugiere que tal vez sería factible traducir una obra de menor envergadura, algo tipo comedia y más breve. Aunque le anuncia que solo si Galdós le busca el contacto con el librero o editor porque él ya no tiene tiempo, materialmente, ni para la familia.

\subsection{Familia de León Roch}

Se publica en 1878 en España. El interés por traducir La familia de León Roch se recoge en tres cartas. Cronológicamente, la primera sería la del señor Eugen Liebich, quien escribe el 13 de septiembre de 1891 (carta número 77), en español. Le informa de que ha leído la obra y que sería el hombre más feliz del mundo si Galdós le autorizara a traducirla. No consta respuesta del escritor.

En segundo lugar, vendría la carta que le dirige Rob. [Robert, tal vez] Krath. La escribe un 27 de abril de 1895 (carta número 87) y la redacta en espańol. En realidad, parece que existe una relación epistolar con el escritor, pues dice «obra en mi poder su grata del 14 [abril, no se lee muy bien] del corriente». Tras una introducción relativa a que dispone de tiempo y tenía la intención de traducir su novela, «más para refrescar mi conocimiento de su hermoso idioma, que para hacer un gran negocio», continúa comentando lo mal pagados que están los traductores, y el poco interés del mercado, para apostillar diciendo que confía en poder vender la traducción a «algún periódico de provincias con los cuales tengo relaciones».

De nuevo aparece la realidad de las traducciones en periódicos; le sugiere que le autorice a él para la traducción de La familia de León Roch, y le anuncia que debe darle libertad para «cambiar el título que será necesario según el gusto de este país». Dada la extensión de la novela propone que le conceda tres años para traducirla. Ignoramos si se produjo la traducción, y no existe respuesta ni anotación en la carta por parte de Galdós. 
La última de las cartas es la de Caroline Altpeter, fechada el 20 de diciembre de 1909 (carta número 1). La remitente escribe en un español no muy correcto, pero entendible. Le comenta que había escrito a primeros de mes y como no ha recibido respuesta, pues escribe de nuevo. Solicita permiso para traducir La familia de León Roch. Desconocemos si se tradujo en esas fechas de nuevo. No consta respuesta del escritor.

\title{
2.15. La mula y el buey y La princesa y el granuja
}

Se publican en 1889, en España. Hemos decidido reunir estos dos relatos en el mismo epígrafe, porque la persona que se interesa por la traducción es, en los dos casos, la misma. El autor sostuvo, por lo que se deduce del epistolario, una relación profesional con Galdós durante algún tiempo. Se trata del Dr. S. Gräfenberg, quien escribe la primera de las cartas el 16 de octubre de 1894 (carta número 33). Todas las cartas están redactadas en español. Se presenta como articulista o comentarista, pues le informa de que la Gaceta de Frankfurt (entendemos que debe referirse al Frankfurter Zeitung, pues alterna ambos nombres en sus cartas):

\begin{abstract}
« (...) me ha encargado de escribir de vez en cuando una revista de la literatura moderna de su país de $\mathrm{V}$. Inducido por un artículo mío sobre su novela de V. Torquemada en la cruz, otro periódico, La Nación, me ha encargado de escribir un artículo más detallado sobre esa novela suya, el cual se publicó en el número del 12 de mayo pasado y que tuve el gusto de mandarle (mediante la Administración de los Episodios nacionales) así bien como mis otros trabajillos que parecieron en la Gaceta de Frankfurt. El que trata de su última novela, Torquemada en el Purgatorio, se publicará pronto en dicho periódico».
\end{abstract}

Solicita autorización para traducir alguna de las novelitas de Galdós y le adelanta que no podrá pagar derechos. En la siguiente misiva, fechada el 21 de noviembre de 1894 (carta número 35), Gräfenberg le participa que: «entretanto he traducido al alemán su preciosa novelita La mula y el buey, para publicarla en el Frankfurter Zeitung a la Navidad. Por eso tendría muchísimo gusto en recibir pronto su grata contestación a mi carta autorizándome a traducir esta y otras de sus novelitas que tanto me agradan».

Queda a la espera de la respuesta de Galdós. Nótese que tanto en la carta 33 como en la 35, se menciona el Frankfurter Zeitung, como periódico interesado en literatura española y que, además, parece que publicará en fechas próximas, se habla de la Navidad de 1895, y de la publicación de la novelita La mula y el buey.

Casi un año después, el 8 de septiembre de 1895 (carta número 37), Gräfenberg vuelve a reiterar su petición para que le autorice a la publicación y le comunica lo siguiente:

«Habiendo aceptado la Gaceta de Frankfurt, una de las más notables de Alemania, mi traducción de su novelita de V. La mula y el buey, y no queriendo yo publicarla sin su licencia, vuelvo a dirigirme a V. suplicándole me de la autorización necesaria. No dejaré de mandarle un ejemplar del periódico correspondiente». 
Desconocemos si se llegó a publicar. No consta respuesta del escritor, aunque cabe especular que viendo la insistencia del autor, es posible que se haya publicado en las fechas que menciona. Nos inclinamos a suponer que así fue, porque la relación epistolar, al menos por parte de Gräfenberg, continúa.

No se conservan en el archivo más que otras tres cartas de este mismo corresponsal. La primera de ella, la escribe tras una pausa de seis ańos, pues la última carta es de septiembre de 1895, y en ella solicita permiso para traducir La princesa y el granuja. El autor se refiere a que la editorial Langenscheidt, especializada en la enseñanza de idiomas, le ha propuesto elaborar una gramática castellana. La carta está fechada el 22 de septiembre de 1901 (carta número 39) y en ella explica a Galdós que pretende ilustrar ejemplos de narrativa española, y ha elegido La princesa y el granuja. De nuevo le solicita permiso para «traducir dicha novelita u otra de las que ha publicado». Se despide como gran admirador del escritor.

La siguiente está fechada un mes más tarde, el 15 de octubre de 1901 (carta número 41), y el autor agradece «la amabilidad con que ha accedido a mis deseos relativos a la publicación y traducción de La princesa y el granuja». Le comunica que está abierto a cambiar si Galdós prefiriera que se tradujera otro cuento de igual extensión o motivo y le dice: «El trozo que quiero publicar ha de contener poca conversación, tanto más narración o descripción, como la historia del casamiento de Pepita Jiménez con D. Gumersindo, la que he sacado de la novela de Don Juan Valera».

Nuestras pesquisas nos llevaron hasta la Biblioteca Nacional de Alemania (Deutsche Nationalbibliothek), donde encontramos, efectivamente, una gramática para estudio del español, cuyo editor es Selly Gräfenberg, en colaboración con Antonio Paz y Meliá. El año de publicación es 1924, puede ser una mera casualidad, pero también puede ser que se trate del proyecto que acariciaba nuestro corresponsal y que comunica a Galdós.

Transcurren ocho ańos desde esta última carta. No nos consta más correspondencia entre Gräfenberg y Galdós, pero debió existir. Lo afirmamos, porque el 8 de noviembre de 1909 (carta número 43) Gräfenberg se toma la molestia de enviar una postal a modo de obsequio a don Benito. Dicha postal contiene el retrato de un insigne escritor alemán, nada más y nada menos, que de Friedrich Schiller. El retrato está recogido en el archivo, pero sin identificar. El texto de la postal es el siguiente:

«Al insigne escritor D. Benito Pérez Galdós dedica esta tarjeta con el retrato del gran poeta de la libertad, cuyo aniversario va a celebrar toda Alemania. S.S.S. [su atento y seguro servidor] y admirador, Dr. Gräfenberg».

\subsection{Propuesta de colaboración en la Revue Internationale}

El 10 de mayo de 1882 (carta número 127), Sacher Masoch, escribe a Galdós y le propone que se convierta en colaborador de su revista. Se trata de la Revue Internationale que él dirige. El escritor solo debe enviarle una novela que él ya se encargará de hacerla traducir. Le escribe por indicación de un amigo común, Fastenrath, ilustre hispanista de la época. Si esa colaboración se produjo, es de imaginar que Doña Perfecta fuera una de esas novelas, que se tradujo gracias a esa oferta de Masoch, en la Revue Internationale, concretamente en el año 1884, novela que leyó Feschke, y que motivó su carta a Galdós proponiéndole convertirse en la traductora al alemán (nota a pie de página número 10, epígrafe 2.2.). 


\subsection{Otra propuesta de traducción sin concretar obra alguna}

Galdós recibe, al menos, tres cartas redactadas por Carlos Schlimbach. La primera de las misivas está fechada el 15 de agosto de 1897 (carta número 129) y redactada en un más que correcto español. Se presenta a sí mismo como escritor alemán y eso le permite tener «las mejores relaciones con los editores» $y$, afirma, «me será fácil lograr las publicaciones que desee». Nótese que se está refiriendo al mundo editorial, pero al comienzo de la carta comenta lo siguiente:

«Desde algún tiempo hay en Alemania un periódico de novelas (que no publica otra cosa) que se dedica, especialmente, a la publicación de novelas estrangeras, ${ }^{9}$ sin diferencia de nación. Gozando la literatura espańola de muy buena fama en Alemania, me he decidido a secundar dicha empresa».

Se presta a traducir lo que Galdós considere, siempre y cuando, la obra no tenga ya una traducción en Alemania. En la siguiente carta, fechada el 28 de agosto de 1897 (carta número 131), Carlos Schlimbach, reitera su petición, pues no ha recibido respuesta por parte de don Benito. Esta carta está tachada en lápiz azul.

Por fin llega la tan ansiada respuesta por parte de Galdós. Carlos Schlimbach detalla en su carta del 21 de octubre de 1897 (carta número 133), que ha recibido carta del escritor fechada el 21 de septiembre de 1897 y se alegra mucho, pero se disculpa por no haber contestado antes. Le expresa que no podrá por ahora traducir obra alguna, porque «creyendo que Ud. no estaba dispuesto a acceder a mis deseos, he hecho ya contrato con otro autor». No obstante, le indica que, tal vez, pueda más adelante y comenta algunos aspectos relativos a las condiciones económicas del contrato, que no vamos a tratar aquí. Sí nos interesa recalcar que informa a Galdós de la posible publicación en «3, 4 o 5 periódicos alemanes a la vez (como no raras veces se lo hace así)». En el siguiente apartado aportaremos más pistas que pueden llevarnos a encontrar otros traductores y otras traducciones, menos conocidas o enteramente desconocidas para los investigadores, que se han podido publicar en periódicos en Alemania.

Esta es la última carta que hemos podido leer de Schlimbach y desconocemos si llegaría a buen término la propuesta de traducir alguna de sus obras. Lo que sí sabemos es que Galdós manifestó su conformidad en una carta escrita el 21de septiembre.

\section{HALMA}

Halma se publica en 1895 y en el epistolario que hemos analizado, figuran cuatro cartas $^{10}$ redactadas por Eberhard Vogel y dirigidas a Galdós, en las que trata la traducción en un importantísimo periódico de Colonia. Hemos encontrado datos sobre esta persona: se trata de un filólogo hispanista, traductor y especializado también en literatura catalana.

9 Figura así en el original y alguien lo ha subrayado como error, ¿sería Galdós?

10 Eberhard Vogel, carta núm. 155, fechada el 27 de enero de 1907; carta núm. 160, fechada el 10 de julio de 1907; carta núm. 162, fechada el 17 de junio de 1907 y carta núm. 167, fechada el 2 de abril de 1904. 
Publica un diccionario de catalán- alemán (1911 y 1916) para la editorial Langenscheidt, así como un diccionario español-alemán.

En su carta de 27 de enero de 1907, Eberhard Vogel le comunica que, con respecto «a la versión alemana de Halma tengo la dicha y el honor de participarle que he logrado colocarla, si no, por ahora en forma de libro, como folletín». A continuación, se explaya para informar que el diario que ha aceptado la traducción es el Kölnische Volkszeitung «diario que pareciendo en tres hojas del tamańo del Imparcial, cuenta con 24.000 suscriptores de las clases ilustradas, y cuya parte literaria y científica goza de universal renombre». Vogel trae a colación la línea ideológica del diario, conservador y católico, para ensalzar, aún más, su proeza, por haber conseguido que le publicaran esa obra de tono anticlerical en un diario tan conservador y católico. Y comenta: «He querido mencionar el carácter del periódico donde Halma [a]parecerá para que Ud. vea cómo los católicos alemanes sabemos apreciar el arte [...]».

El traductor, Eberhard Vogel, le comunica que la novela aparecerá y, en algún momento entre la carta del 17 de junio y la del 10 de julio de 1907, envía un recorte del propio periódico, en el que se informa de la próxima aparición de la novela de Galdós en el Feuilleton (imagen 1).

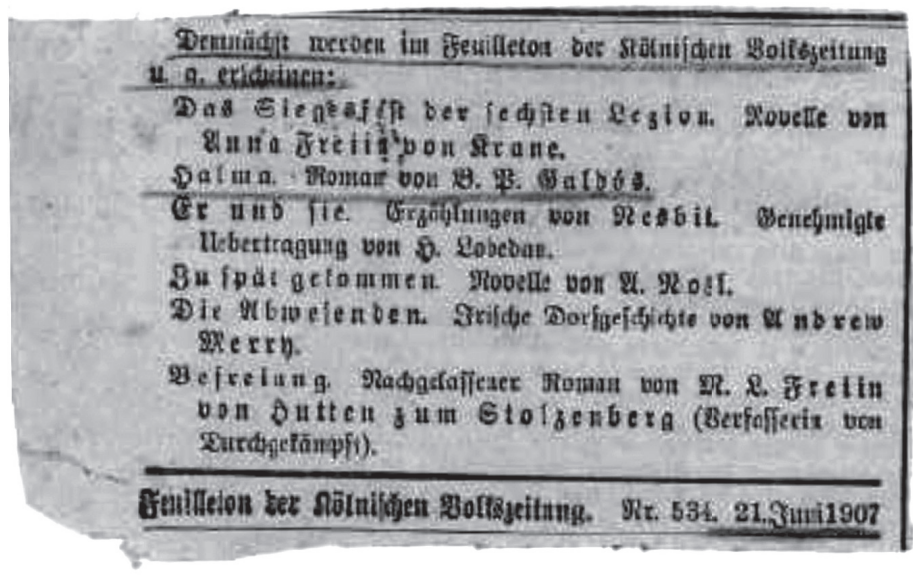

Imagen 1. Recorte del anuncio de la Kölnische Volkszeitung, enviado por Vogel.

Traducción del texto del recorte:

Algunos títulos de próxima aparición en el Feuilleton der Kölnischen Volkszeitung,

[...]

Halma. novela de B. P. Galdós.

[...]

Feuilleton der Kölnischen Volkszeitung. Nr. 534. 21 de junio de 1907.

[Traducción propia] 
Nótese el subrayado con lápiz azul que destaca aspectos informativos importantes, como son el nombre de la novela, Halma, y la fecha del folletín (número 534, de 21 de junio de 1907), en el que se inserta este avance sobre las novelas que se van a publicar. En su carta de 17 de junio de 1907, Vogel le informa que el diario se va a demorar en la publicación, porque habían publicado una novela, recientemente, en el folletín y los personajes «vivían también en la esfera clerical, lo que no había gustado a todos los lectores. El día que se comience a publicar, enviaré la cuota que le corresponde a Ud., aun antes de que se me pague a mí. De lo demás, hablaremos».

Los acuerdos económicos ya se habían detallado en la carta de 27 de enero de 1907: «De la suma de marcos 500 que se me pagará por esta primera publicación, le enviaré 75 en cuanto la cobre, y lo mismo $15 \%$ de la segunda, si la consigo».

En la siguiente carta, de 10 de julio de 1907, y última de Vogel, este le informa de lo siguiente:
«Muy señor mío y de mi consideración más distinguida:
La Administración del diario Kölnische Volkszeitung me ruega le participe a Ud. que desde el día en que comenzó la publicación de su valiosa novela Halma, se le transmitirá todos los días la edición completa del diario en dos ejemplares, según Ud. deseaba. Suplico a Ud. me ceda un ejemplar de Nazarín que es difícil obtenerlo aquí, para que lo lea y vea de publicar des- pués toda la novela en forma de libro».

En otras palabras, se infiere que la novela se publicó, efectivamente, en el Feuilleton de la Kölnische Volkszeitung. Lamentablemente, no hemos podido encontrar en formato digital este diario en las bibliotecas alemanas. Sucede que este periódico, auténtico pilar del poder católico en Alemania, sufrió durante la Segunda Guerra Mundial una terrible pérdida. Los bombardeos de los aliados dieron de lleno en los archivos de este periódico, por lo que resulta muy complicado, por no decir imposible, encontrar ejemplares de este diario. En palabras de Andreas Burtscheidt (2019: 35):

«Bei der Aufarbeitung von Geschichte und Redaktionsarbeit der "Kölnischen Volkszeitung" stößt der Bearbeiter aber unausweichlich auf die Schwierigkeit einer durchweg dürftigen Quellenbasis. Für die Jahre zwischen 1860 und 1920 ist zu konstatieren, dass das gesamte Verlagsarchiv des J.P. Bachem-Verlages in Köln während des Zweiten Weltkrieges Opfer der englischen und amerikanischen Bombenangriffe auf die Kölner Innenstadt wurde. (Vergleiche W. Ebel, Das Feuilleton einer Tageszeitung, Vorwort, S.I. Schon damals haben Nachfragen Ebels bei der Leitung des Bachem-Verlages in Köln zu keinem Ergebnis geführt, vgl. EBD., S.10)».

[Cualquier investigador que pretenda estudiar la historia y el trabajo de la redacción de la „Kölnischen Volkszeitung" tropezará, inevitablemente, con una realidad que complica y dificulta la tarea: la escasez de fuentes documentales. Para los años comprendidos entre 1860 y 1920, no existen datos, pues se constata que el archivo de la editorial J.P. Bachem al completo fue víctima del bombardeo de los americanos y los ingleses sobre el centro de la ciudad de Colonia, durante la segunda guerra mundial (Consultar la obra 
de W. Ebel, Das Feuilleton einer Tageszeitung [El Feuilleton de un diario], prólogo, S.I. Ya por aquel entonces, Ebel se dirigió a la dirección de la editorial Bachem en Colonia, sin obtener resultado alguno, consultar ibídem p. 10)]

Traducción propia.

Este dato relativo al destino sufrido por el archivo del Feuilleton complica, aún más, la búsqueda de esa posible traducción desaparecida de la que queda constancia en las cartas con su probable traductor, Eberhard Vogel.

\section{CONClusiones}

De la lectura de la correspondencia sostenida por Galdós con quienes se postulaban para traducir sus obras, se deducen varias cosas: la primera, que todos ellos tuvieron conocimiento de la obra de Galdós bien a través de la prensa alemana o de la prensa francesa. Este dato se extrae, directamente, del contenido de sus cartas, pues muchos señalan el nombre del periódico o simplemente se hacen eco de lo que publicaba la prensa europea de los éxitos literarios de Galdós. En segundo lugar, que debido a esa repercusión en prensa se convirtió en un autor muy conocido en Alemania, debiendo atender a las solicitudes de personas, editoriales y teatros que deseaban dar a conocer su obra en alemán. En tercer lugar, que su obra se tradujo al alemán en vida del propio escritor, tanto en formato libro como en suplementos literarios de algunos periódicos. En cuarto lugar, que gracias al estudio de esta correspondencia hemos encontrado datos que prueban de manera indiciaria y alguna otra prueba material, como es el recorte de periódico que aportamos, que es más que probable que existan otras traducciones publicadas en prensa y que no han sido recogidas en las bibliografías hasta la fecha. Sabemos que eran los propios corresponsales los que le sugerían la publicación de las traducciones en suplementos, diarios, gacetas o periódicos que estaban especializados en la publicación de literatura. Sabemos por sus cartas que Galdós solía conceder un plazo de un año para la realización de cualquiera de sus traducciones. En el caso de las cartas 83, 37, 39 y 41 como hemos visto, Galdós concedió permiso para traducir, pero ignoramos si estas obras vieron o no la luz, y queda pendiente de una investigación posterior. Asimismo, es posible que coexistan más de una obra con traductor diferente, como es el caso, de Marianela (1888 y 1903) que cuenta con dos traductores distintos. No obstante, puede que exista alguna versión más, pues Galdós había autorizado ya en 1885 a Arthur Rochl para que la tradujera también.

El estudio de las cartas con sus traductores reales y potenciales ha revelado datos inéditos sobre la publicación de otras traducciones en alemán, desconocidas hasta el momento. Constituye una línea de investigación que no está agotada y que confiamos que pueda servir para actualizar, revisar y corregir las bibliografías actuales. 


\title{
CAPÍTULO III
}

\author{
Visibilidad frente a invisibilidad del traductor en las obras de \\ Pérez Galdós al alemán \\ Pilar Martino Alba \\ Universidad Rey Juan Carlos de Madrid
}

\section{INTRODUCCIÓN}

La recepción de Benito Pérez Galdós (1843-1920) en Alemania se puede considerar tardía, pues aunque una de sus obras, Gloria, se traduce ya en 1880, Doña Perfecta en 1886, y La campaña del Maestrazgo en 1902, el resto tendría que esperar hasta los años sesenta para que los editores del polisistema de lengua y cultura alemanas se interesaran realmente por el gran novelista español. De la dos decenas de obras de Pérez Galdós traducidas al alemán, tres han sido abordadas por mujeres. En una de ellas, el supuesto nombre de la traductora esconde una invisibilidad deseada. De esas versiones emprendidas por traductoras, a saber: Tristana, por Erna Pfeiffer en 1989; Marianela, por Gertrud StrohmKatzer y Carmen Wurm, en 2000; y La campaña del Maestrazgo, por una tal «Doña Servita», hemos escogido esta última, que constituye la quinta novela de la tercera serie de los Episodios nacionales. Esa novela sobre los avatares de los contendientes por la legitimación de los posibles sucesores al trono de España fue vertida al alemán en 1902, como hemos apuntado más arriba, con el título Der Roman einer Nonne (La novela de una monja). En ella tratamos de averiguar datos sobre su recepción en la cultura de expresión alemana y seguir las huellas de la supuesta traductora en unos textos que tienen como protagonista principal a una mujer, Marcela, aunque el contexto sea el crudo relato de las escaramuzas y comportamiento violento de los participantes en nuestras contiendas entre carlistas y cristinistas o isabelinos. Tanto el texto como el contexto en el que se desarrolla la novela requieren de altas dosis de creatividad en la traslación de referentes culturales. Una dificultad añadida es la presencia de textos fuertemente marcados con expresiones propias del entorno geográfico en el que se desarrolla el episodio. Topónimos, algunos con connotaciones culturales; antropónimos que esconden, en determinados casos, un segundo sentido; apodos y sobrenombres; neologismos que reflejan una gran sensibilidad lexicográfica; presencia de latinismos; de dichos populares y refranes; uso por parte del autor de diferentes registros sociales en los diálogos; doble sentido y fino humor cargado de retranca galdosiana, una complicada urdimbre, en fin, conforma un texto en cuyo 
pormenorizado análisis hemos tratado de detectar la impronta de la traductora y su acercamiento o alejamiento al muy personal estilo literario de Pérez Galdós, teniendo en cuenta los presupuestos venutianos sobre la invisibilidad del traductor. Así pues, desde el punto de vista teórico, Venuti ha sido el punto de partida para determinar la calidad de un texto traducido al alemán que, supuestamente, debía extender el buen hacer de una pluma literaria considerada a la altura de los grandes novelistas del XIX y comienzos del XX, teniendo en cuenta estrategias y técnicas adoptadas por la supuesta traductora, dońa Servita, y si esas decisiones, que Venuti enlaza directamente con la condición de escritor, intelectual e investigador, se podrían aplicar para evaluar el producto traducido objeto de nuestro interés.

La invisibilidad del traductor venutiana está basada en la afirmación de Walter Benjamin de que la verdadera traducción es translúcida (Die wahre Übersetzung ist durchscheinend), idea que incluía en su ensayo sobre la tarea del traductor (Die Aufgabe des Übersetzers), publicado en 1921. En el artículo fundacional sobre la invisibilidad del traductor y que daría lugar a un clásico de la teoría de la traducción, L. Venuti (1986: 179) afirmaba que en el estudio de las traducciones literarias había problemas que no gozaban de la atención de los investigadores y eran, por un lado, la importancia que tenía el lector meta con respecto al traductor y, por otro lado, los criterios traductivos, así como la evaluación del texto traducido:

«On the one hand, readers usually respond to the translation of a foreign text, whether prose or poetry, as if the text had been originally written in their language, as if it were not in fact a translation; on the other hand, a translation is judged acceptable (by editors, reviewers and readers) when it reads fluently, when the absence of any awkward phrasings, unidiomatic constructions of confused meanings gives the appearance that the translation reflects the foreign author's personality or intention or the essential meaning of the original text $[\ldots] »$

El traductor tiene que intervenir obligatoriamente en el texto, pues esta intervención forma parte del proceso traductor y el éxito de la misma dependerá de la mayor o menor invisibilidad del actor de dicho proceso, de manera que si el lector detecta al traductor durante la lectura del texto meta, ello implicará que en ese proceso ha habido fallos, al quedar relegada la fluidez en la lectura, tal y como ponen de manifiesto editores, críticos y lectores, según afirma Venuti en el párrafo anteriormente citado. Si bien sus investigaciones sobre el concepto de invisibilidad están basadas en su propio trabajo como traductor literario y en la crítica de la situación de los traductores literarios en las culturas anglosajonas, se apoyan en autores que previamente habían aludido a la transparencia de los textos literarios traducidos, como el citado Benjamin o el poeta y traductor literario Norman Shapiro. Ya en el siglo XIX, Friedrich Schleiermacher (1813) se había referido a la transparencia, por un lado, o a las sutiles veladuras, por otro, con las que el traductor imprime su texto, aunque lo formulaba con los términos de domesticación o extranjerización como estrategias de traducción. 
En el año 2007 Lawrence Venuti ${ }^{1}$ reafirmándose en su idea del traductor invisible, exponía que «El texto traducido produce de inmediato efectos lingüísticos y culturales diferentes; la lectura debe ser más formalista, tener en cuenta aspectos lingüísticos, terminológicos, sintaxis, etc. No solo hay que atender al sentido, sino que hay que hablar de los aspectos estilísticos y formales». A propósito de esto, insistía en la condición de escritor, intelectual e investigador inherente al traductor durante su trabajo translatorio y en la importancia de la toma de decisiones sobre la estrategia de domesticación o extranjerización a la hora de abordar una traducción literaria, estrategia que repercute directamente en la visibilidad o invisibilidad del traductor y, consecuentemente, en el efecto que el texto traducido produce en el lector. En la segunda edición de su obra, Venuti (2008: 1) profundiza en la idea de invisibilidad, abordando los géneros literarios en prosa en los que no se había adentrado en la primera edición, al tiempo que destaca los papeles del traductor y del lector en el camino que el texto original recorre hasta llegar a la cultura meta.

\begin{abstract}
"The illusion of transparency is an effect of a fluent translation strategy, of the translator's effort to insure easy readability by adhering to current usage, maintaining continuous syntax, fixing a precise meaning. But readers also play a significant role in insuring that this illusory effect occurs [...] What is so remarkable here is that the effect of transparency conceals the numerous conditions under which the translation is made, starting with the translator's crucial intervention. The more fluent the translation, the more invisible the translator, and, presumably, the more visible the writer or meaning of the foreign text».
\end{abstract}

Teniendo en cuenta estas premisas venutianas, hemos leído el texto galdosiano en alemán, a sabiendas de que, instintivamente, se podrían producir interferencias debidas, por un lado, al conocimiento previo de la obra de Pérez Galdós y su muy particular estilo literario en la escritura de novela histórica, y, por otro lado, al conocimiento personal de la geografía y la toponimia del Maestrazgo.

\title{
2. LA CAMPAŃA DEL MAESTRAZGO
}

\subsection{Contextualización de la obra}

La campaña del Maestrazgo, traducida al alemán como Der Roman einer Nonne (La novela de una monja) es la quinta novela de la tercera serie de los Episodios nacionales de Pérez Galdós. Concluye y firma la obra en 1889, la publica en Madrid, en la Tipografía de la Viuda e Hijos de Tello diez años después, en 1899, aunque los hechos relatados en esta novela histórica se corresponden con la primera guerra carlista (1833-1840), cuando el general Cabrera se hace fuerte en la región turolense y castellonense del Maestrazgo hasta

1 La referencia corresponde a la intervención de L. Venuti en el Coloquio Lucentino de Traducción, organizado por M. Á. Vega Cernuda en la Universidad de Alicante, y a las notas personalmente tomadas durante su intervención y posterior coloquio con el conferenciante. Su aportación a ese congreso fue después publicada con el título «Traducción, empirismo, ética» (2007: 99-122). Véase bibliografía. 
que fue derrotado en 1840. Las guerras carlistas se originaron por el enfrentamiento entre los partidarios de Carlos María Isidro de Borbón a la Corona de Espańa, y la descendiente de Fernando VII con derecho al trono, Isabel II, hija de María Cristina de Borbón Dos-Sicilias, llamados «carlistas», los primeros, y «cristinistas» los segundos.

\subsection{Argumento y personajes}

El argumento de la novela galdosiana gira en torno a los avances del general Cabrera en las tierras montańosas del Maestrazgo, cuya campaña la detalla nuestro autor con prolijidad tanto en la descripción paisajística como urbana, y, por supuesto, en las relaciones personales entre los diferentes personajes de uno y otro bando. En el desarrollo de la campaña hay lugar para la expresión de ideas sobre el devenir y significado de una guerra fratricida, sobre las reacciones humanas en situaciones de conflicto bélico, lo que abre el abanico para presentar al lector a un sinfín de personajes de todo jaez y condición social. La violencia, la brutalidad de una sociedad que se deja llevar por sentimientos e ideología irreflexiva, la brutal condición lupina del hombre para el hombre, la manifestación de los más bajos y primitivos instintos en situaciones de supervivencia, sin tener en cuenta el respeto que todo ser humano merece, provenga de donde provenga, forman parte de la madeja de complicadas relaciones personales que desarrollan los protagonistas en la novela. Las condiciones infrahumanas a las que se ven sometidos en su avance los contendientes, enviados a la lucha sin cuartel como si fuesen al matadero, conforma también una panoplia de personajes entrelazados por sentimientos encontrados. En palabras del crítico literario Eduardo Gómez Baquero, quien firmaba sus críticas con el seudónimo de Andrenio (1918: 13), las novelas históricas de los Episodios nacionales están «llenas de interés y de emoción humana, y en las cuales lo que la ficción añade a los sucesos y personas de la historia, interesa tanto o más que estos».

Los personajes secundarios son múltiples, pero los principales, digamos que fundamentales para el desarrollo de la historia que relata la novela, son los siguientes: El general Ramón Cabrera, protagonista de la campaña del Maestrazgo y que, a raíz del asesinato de su madre a manos de los enemigos, actuará con venganza y violencia desmedidas; el marqués de Urdaneta, don Beltrán, noble arruinado, que trata de recuperar su antańa riqueza, perdida por exceso de generosidad y despilfarro; Marcela, una joven metida a monja, hija de Juan Luco, quien fuera arrendatario de extensas tierras del marqués y que gracias a su laboriosidad y prudencia en los gastos terminó por hacerse con la fortuna del marqués de Urdaneta; Nelet o Manuel Santapau, un hombre primitivo y violento, perdidamente enamorado de Marcela. Por lo que respecta a los secundarios, algunos son determinantes para el desarrollo de los acontecimientos relatados, como sería el caso de Salomé Ulibarri —mujer del alférez Baldomero Galán, constantemente dispuesta a echar una mano a su antiguo señor—; María Griñó —-madre del general Cabrera—; Alfajar y Pedro Zaida, los dos enterradores o sepultureros que sistemáticamente acompanaban a Marcela, la monja errante, en sus desplazamientos; el capellán del regimiento, mosén Putxet, siempre debatiéndose entre su conciencia y su obligación para con la dirección espiritual de los contendientes; Zumalacárregui, Llangostera, Malaena, Pulpis, Forcadell, y un sinfín más de mandos al frente de las divisiones que avanzaban por las serranías y valles turolenses y castellonenses. En la cohesión de los hechos relatados, cada uno de 
estos personajes secundarios cumple un papel coherente con la estructura que Pérez Galdós ha dado a su novela.

\subsection{Referentes culturales en La campaña del Maestrazgo}

La producción literaria de Pérez Galdós pone de relieve la excelente documentación del autor para la contextualización de sus obras. Y por lo que respecta a los Episodios nacionales, en particular, una de cuyas novelas históricas es la que conforma nuestro objeto de interés en esta aportación, La campaña del Maestrazgo, refleja el profundo conocimiento geográfico de Galdós, bien a través de visitas personales o de la atenta y escrutadora consulta de mapas y planos del terreno que pisan sus personajes.

El apoyo de la novela histórica en nombres propios, hechos históricamente comprobados y topónimos reales contribuye a crear sensación de veracidad sobre lo narrado e imbricación entre lo ficcional y lo real, de manera que se crea entre ambos una bien tramada simbiosis. Así pues, consideramos que en la traducción de novela histórica es relevante prestar especial atención a antropónimos y topónimos al decidir entre la estrategia de domesticación o de extranjerización. Además de ello, en el texto de Pérez Galdós es más que abundante la presencia de variantes diatópicas, diastráticas y diafásicas, a las que se une una rica fraseología y un sinfín de realia alusivos a elementos constructivos y estilos artísticos, tejidos y vestimenta, cargos militares, hechos históricos sobradamente conocidos, especies botánicas, objetos artesanales, etc., lo cual dificulta sobremanera la tarea durante el proceso versor. Por estas razones, en la lectura del texto traducido al alemán hemos focalizado la atención especialmente en antropónimos, topónimos, referentes culturales, fraseología y variantes lingüísticas para comprobar hasta qué punto se puede llegar a conclusiones válidas sobre la calidad de la traducción al alemán de esta novela de Pérez Galdós, teniendo en cuenta estrategias y técnicas adoptadas por la supuesta traductora, doña Servita, y si esas decisiones, que Venuti enlaza directamente con la condición de escritor, intelectual e investigador, se podrían aplicar para evaluar el producto traducido objeto de nuestro interés.

\section{La TRAdUCCIÓN AL ALEMÁN DE LA CAMPAÑa DEL MAESTRAZGO}

\subsection{Razones editoriales para el cambio de título: Der Roman einer Nonne}

La obra de Pérez-Galdós La campaña del Maestrazgo se publica en alemán en la editorial Sachs \& Pollack, ${ }^{2}$ con sede en Viena y Budapest, que tenía en su catálogo algunas obras eróticas que habían sido prohibidas por la procacidad de su contenido (Schmuck, Gorzny y Geils, 1982), en el que las protagonistas eran mujeres caracterizadas por despuntar como

2 Otras obras traducidas desde diferentes lenguas al alemán y publicadas en la editorial Sachs\&Pollack en torno al año de publicación de Der Roman einer Nonne (La novela de una monja, es decir, La campaña del Maestrazgo) fueron: Entartete Weiber, de Jane de la Vaudere, 1900, autora que había escrito una novela de una monja expulsada del convento; Die Liebesabenteuer des Chevalier von Faublas, de Jean-Baptiste Louvet de Couvray, 1903; Die Agonie, de Jean Lombard, 1903; Hungara-Hungarische Mädchen auf dem Markte. Enthüllungen über den internationalen Mädchenhandel, de Julius Kémeny, 1903 , etc. 
adelantadas a su época. La traducción la firma «Doña Servita», un nombre a todas luces ficticio o semioculto que parece ofrecer pistas sobre una traductora conocedora de la vida monacal. ${ }^{3}$ El cambio radical de título, que en la versión al alemán hace alusión a la condición de religiosa de una de las protagonistas de la novela, aunque también podría remitirnos al término italiano «donna servita», a saber, una moza a la que se espera y a la que se hace la corte, parece tener que ver con ideas mercadotécnicas, ya que el título original, La campaña del Maestrazgo, tanto por el topónimo como por el contenido de las guerras fratricidas entre carlistas y cristinistas no parecería tener, a priori, un potencial interés lector en el polisistema cultural en lengua alemana. El texto original, en la edición que hemos consultado, consta de 127 páginas, mientras que la traducción citada, publicada en 1902, consta de 68 páginas, lo que ya nos proporciona una idea bastante clara de que no se trata de una traducción, sino de una versión reducida. Además de ello, los XXI capítulos del texto original se convierten en tan solo ocho en la versión al alemán de «doña Servita».

\subsection{Estrategias y técnicas traductoras frente al inimitable estilo galdosiano}

La lectura de la obra de Pérez Galdós en lengua original constituye para el lector un delicioso transcurrir por páginas plagadas de localismos, neologismos, ingeniosos símiles, analogías, eufemismos, metáforas, expresiones propias de la rica fraseología utilizada por el pueblo llano, además de un sinfín de topónimos que dan cuenta de los conocimientos enciclopédicos del autor canario de nacimiento, madrileño de adopción y universal de escritura y pensamiento. La lectura de la traducción resulta agradable y fácil, sin sobresaltos estilísticos, lo que ya da idea de que, además de la reducción del texto, se ha procedido a una simplificación estilística. Esto sin tener en cuenta que para un lector de esta obra galdosiana en la lengua original, y buen conocedor, para más señas, de la geografía y la toponimia no solo del Maestrazgo, sino de las comunidades aragonesa y valenciana implicadas en el texto, y que domina la lengua terminal, algunas de las decisiones tomadas por la traductora dañan la vista y el oído, al pronunciar en voz alta la versión que esta ha dado a los topónimos y antropónimos. Antes de adentrarnos en detalles relativos a posibles técnicas utilizadas por la traductora para la traslación de topónimos, antropónimos, referentes culturales, etc., permítasenos traer a colación un párrafo completo de la primera página del texto original y del texto meta, que transcribimos a continuación, para dar idea de hasta qué punto es un texto marcado por todos estos citados aspectos que hemos mencionado más arriba. Subdividimos ese párrafo en tres partes $(\mathrm{a}, \mathrm{b}, \mathrm{c})$ que comentamos brevemente tras cada una de ellas.

2 La canonización de los siete santos fundadores de la Orden de los Servitas, nacida en Florencia a mediados del siglo XIII, tuvo lugar en 1888, un año antes de que Pérez Galdós terminara el texto de $L a$ campaña del Maestrazgo, que firmó en Santander en abril-mayo de 1889. 


\begin{tabular}{|c|c|}
\hline $\begin{array}{l}\text { Pérez Galdós, La campańa del Maestrazgo } \\
\text { (1900: 1a) }\end{array}$ & $\begin{array}{l}\text { Dońa Servita, Der Roman einer Nonne } \\
\text { (1902: 1a) }\end{array}$ \\
\hline $\begin{array}{l}\text { "No por los hechos históricos que ilustran esta } \\
\text { villa (pues en lo antiguo dicen que fue lugar } \\
\text { de moros, y algún chinazo le tocó en la gue- } \\
\text { rra de la Independencia y en los dos inmor- } \\
\text { tales sitios); no por la fertilidad de su término, } \\
\text { regado por el Canal Imperial; no por las es- } \\
\text { tameńas que fabrican sus tejedores, ni por las } \\
\text { excelentes lechugas que crían sus huertas, ni } \\
\text { tampoco por su gótica iglesia parroquial, } \\
\text { donde yacen, en desmoronados sepulcros, } \\
\text { multitud de Condes de Fuentes que rabiaron } \\
\text { o hicieron rabiar al pueblo, aparece este en la } \\
\text { primera página de la presente relación, sino } \\
\text { por la fama del parador de Viscarrués, situado } \\
\text { en la plaza junto a la llamada casa del Rey, el } \\
\text { cual gozaba de gran crédito y favor entre los } \\
\text { arrieros y trajinantes que comunicaban a Za- } \\
\text { ragoza con el Reino de Valencia. Asimismo } \\
\text { confluían allí los trayectos peoniles y carro-- } \\
\text { materos de la parte de Alcańiz, del Maes- } \\
\text { trazgo y Vinaroz, de la tierra baja de Teruel, } \\
\text { Híjar y la cuenca del río Martín. }\end{array}$ & $\begin{array}{l}\text { "Obgleich Fuentes del Ebro unter den } \\
\text { Mauren ein wichtiger Platz gewesen war, } \\
\text { obgleich es zur Zeit der } \\
\text { Unabhängigkeitskriege eine bedeutende } \\
\text { Rolle spielte, und obwohl es eine reiche } \\
\text { Fabriksstadt geworden, wo der größte Theil } \\
\text { der im Norden Spaniens gebrauchten } \\
\text { Beuteltuche erzeugt wird, ist weder seine } \\
\text { Antiquität, noch sein Reichthum, noch aber } \\
\text { die wirklich sehr schöne gothische } \\
\text { Kathedrale dieser Stadt die Ursache, daß der } \\
\text { Name Fuentes del Ebro am Anfange dieser } \\
\text { Erzählung steht, und wenn wir den Leser } \\
\text { hinführen, so geschieht dies nur, um ihn mit } \\
\text { dem Gasthause des Viscarrués bekannt zu } \\
\text { machen. Dieses Gasthaus, das auf dem } \\
\text { großen Quellenplatze, neben dem alten } \\
\text { „Königsbau« liegt, erfreute sich zur Zeit, als } \\
\text { unsere Erzählung beginnt, in der ganzen } \\
\text { Umgebung großen Ansehens. Es war der } \\
\text { Zusammenkunftsort der Maultiertreiber, } \\
\text { Kärrner und Reisenden, die von Saragossa } \\
\text { nach der Provinz Valencia zogen.Der } \\
\text { gesamte Handel von Alcanniz, Maestrazgo, } \\
\text { Vinnaroz und des Rio Martin-Thales hatte } \\
\text { hier seinen Knotenpunkt. }\end{array}$ \\
\hline
\end{tabular}

En este primer fragmento Pérez Galdós contextualiza el espacio geográfico donde se desarrolla la novela, y el espacio solariego, un fondo que cobra relevancia en el texto como punto de encuentro principal de los personajes que actuarían en la campańa del Maestrazgo, tanto protagonistas como secundarios. Abundan, pues, los topónimos y los referentes culturales que sitúan al lector en el contexto. En la pausada descripción, nuestro autor hace referencia a la relevancia histórica del lugar aludiendo a la importancia del predio durante la guerra de la Independencia y «los dos inmortales sitios» de Zaragoza, en junio y diciembre de 1808 respectivamente. Para resaltar aún más la significación histórica, Pérez Galdós alude al Canal Imperial de Aragón, la gran obra hidráulica de finales del siglo XVIII, que baña la población de Fuentes de Ebro. En la traducción han sido omitidos estos referentes culturales: los sitios de Zaragoza y el Canal Imperial. También se omite otro detalle relacionado con la trascendencia del lugar, pues el texto original alude a los enterramientos de los Condes de Fuentes en la iglesia parroquial, información histórica que se omite en el texto meta, en el que, además, como veremos también más 
adelante, la iglesia parroquial ha quedado convertida en catedral, de manera que la traductora, al elevar la categoría del edificio religioso, ha dado relieve a la población pero para ello ha utilizado referentes culturales distintos a los que aparecen en el texto original.

\begin{tabular}{|c|c|}
\hline $\begin{array}{l}\text { Pérez Galdós, La campaña del Maestrazgo } \\
\text { (1900: 1b) }\end{array}$ & $\begin{array}{l}\text { Doña Servita, Der Roman einer Nonne (1902: } \\
\text { 1b) }\end{array}$ \\
\hline $\begin{array}{l}\text { Los barqueros del Canal Imperial, así como } \\
\text { todo el personal de fontanería, eran también } \\
\text { fieles parroquianos de Viscarrués, el cual daba } \\
\text { excelente trato a las caballerías primero, a las } \\
\text { personas después, y poseía un amplio local } \\
\text { con cuadras extensas, donde podían acomo- } \\
\text { darse, entre animales y arrieros, como unos } \\
\text { treinta pares. En el piso alto no faltaban apo- } \\
\text { sentos para señores, algunos hasta con camas, } \\
\text { otros bien acondicionados de mullidos jergo- } \\
\text { nes. Era la cocina monumental, con el hogar } \\
\text { guarnecido de poyos, y por uno y otro lado } \\
\text { mesas largas, donde podían tomar el pienso } \\
\text { hasta veinte parroquianos. Servía Viscarrués } \\
\text { un Cariñena superior, sin competencia en } \\
\text { cuatro leguas a la redonda, y para todo pasto } \\
\text { un tintillo de Contamina que en lo de alegrar } \\
\text { corazones y cabezas parecía hermano de la } \\
\text { jota. Uno y otra procedían de la misma cepa. }\end{array}$ & $\begin{array}{l}\text { Der Gasthof enthielt große Stallungen, in } \\
\text { welchen sich dem alten spanischen Brauche } \\
\text { entsprechend Maulthiertreiber und ihre } \\
\text { Thiere Seite an Seite aufhielten; im ersten } \\
\text { Stockwerke befanden sich die für vornehmere } \\
\text { Reisende bestimmten Zimmer, in welchen es } \\
\text { auch - eine recht seltene Sache zu jener Zeit! } \\
\text { - wohlversehene Betten gab; um aber der } \\
\text { Wahrheit treu zu bleiben, muß man sagen, } \\
\text { daß es in den meisten Zimmern nur auf dem } \\
\text { Boden ausgebreitete Strohsäcke gab. Die } \\
\text { Küche war von riesiger Ausdehnung; ein } \\
\text { monumentaler Kochherd nahm den } \\
\text { Hintergrund ein und beschützte mit seinem } \\
\text { breiten Mantel die rechts und links vom } \\
\text { Feuer placirten Bänke, während zwei große } \\
\text { Tische, an denen zwanzig Personen bequem } \\
\text { speisen konnten, die Seitenwände einnahmen. }\end{array}$ \\
\hline
\end{tabular}

En este segundo párrafo aparece en la lengua original nuevamente mencionado el Canal Imperial de Aragón, en este caso para referirse a los barqueros. Al haber desaparecido en el texto meta el Canal Imperial, tampoco se alude ahora a los barqueros como personajes que frecuentaban el parador de la familia Viscarrués. En la detallada descripción de las (in)comodidades de la posada, la traductora introduce un comentario propio de los viajeros extranjeros cuando se desplazaban por Espańa: Eine recht seltene Sache zu jener Zeit! (;Algo realmente inusual en aquellos tiempos!) dice la traductora cuando Pérez Galdós en el texto original menciona que había también aposentos bien acondicionados para señores. Por otro lado, nuevamente referentes culturales muy propios de la zona, como el vino de Cariñena, la importante región vitivinícola aragonesa, o el vino de Contamina, población cercana a Calatayud, desaparecen del texto meta. 


\begin{tabular}{|c|c|}
\hline $\begin{array}{l}\text { Pérez Galdós, La campaña del Maestrazgo } \\
\text { (1900: 1c) }\end{array}$ & $\begin{array}{l}\text { Doña Servita, Der Roman einer Nonne } \\
\text { (1902: 1c) }\end{array}$ \\
\hline $\begin{array}{l}\text { Los más de los días Viscarrués y su familia } \\
\text { no tenían manos para servir a la mucha y } \\
\text { diversa gente que en el parador se juntaba. } \\
\text { Uno de los criados, llamado Guasa (ver- } \\
\text { dadero apellido, no apodo), natural de } \\
\text { Jaca, y más vivo que el azogue, hacía mi- } \\
\text { lagros de ubicuidad y diligencia. Pero llegó } \\
\text { un día; mejor dicho, llegaron tres días, en } \\
\text { que ni el ventero con sus hijas y su mujer, } \\
\text { ni Guasa con toda su agilidad ratonil, pu- } \\
\text { dieron atender al golpe de personas y acé- } \\
\text { milas que se metieron por aquellas puertas } \\
\text { con hambre y sed, pidiendo vino, cebada, } \\
\text { carne y un montón de paja para dormir." }\end{array}$ & $\begin{array}{l}\text { In gewöhnlichen Zeiten vermochte es } \\
\text { Viscarrués, von seiner Familie und einem } \\
\text { Dienstboten unterstützt, seine zahlreichen } \\
\text { Gäste zu bedienen, die in seinem Gasthofe } \\
\text { sich versammelten; aber es kam ein Tag, } \\
\text { wo der Wirth, seine Frau, seine Töchter } \\
\text { und sein Dienstbote unfähig waren, den } \\
\text { Anforderungen der Menschen und Thiere } \\
\text { zu entsprechen, die zu gleicher Zeit die } \\
\text { Schwelle des Gasthofes übertraten } \\
\text { hungernd und dürstend nach Brod und } \\
\text { Wein schrien, nach Hafer für die Thiere } \\
\text { und nach Stroh für ihre Lagerstätte." }\end{array}$ \\
\hline
\end{tabular}

Por último, en este tercer fragmento que traemos a colación para poner al lector en situación de las posibles técnicas utilizadas por la supuesta traductora del texto al alemán, las modificaciones hacen referencia a figuras retóricas que Pérez Galdós utiliza para describir a uno de los personajes secundarios, tales como «más vivo que el azogue» o «agilidad ratonil», y que no figuran en el texto terminal, omisión quizá justificada en que en el texto meta se omite el nombre del personaje y, consecuentemente, la descripción sobre su carácter y forma de ser.

En estos tres fragmentos, es perceptible que en la traducción al alemán se ha producido una manipulación en el sentido que Venuti defiende, a saber, la necesaria intervención del traductor en el texto original para que pueda ser leído en la lengua meta como si hubiese estado escrito originalmente en esa lengua. Sin embargo, a pesar de esa necesaria intervención, es obvio que se ha prescindido de aquellos términos con doble sentido o cuyo significado está cargado de ironía, como en el caso del apellido del criado Guasa, del que el propio Pérez Galdós aclara en el texto original que se trata de un verdadero apellido y no de un apodo. Como veremos más adelante, se produce una indudable adaptación del texto original a los intereses editoriales y al público meta, como en el ejemplo siguiente, cuando el marqués de Urdaneta afirma, a propósito de la protagonista, Marcela: «Hace tiempo — dijo D. Beltrán—, que a mí llegó la fama, no solo de su santidad, sino de su vivo entendimiento.» (cap. III, p. 21), mientras que en el texto en alemán se dice lo siguiente: "Ich hörte auch schon lange von ihrer lebhaften Geistesbildung, bemerkte Don Beltran, aber sagt mir, wie sieht Marcela aus, ist sie schön? Entsprechen ihre Züge und ihre Gestalt der rassigen Schönheit aller Lucos?». ${ }^{3}$

3 La cursiva es nuestra para destacar aquello que se añade al texto vertido al alemán y que no aparece en el texto original de Pérez Galdós en esa intervención de don Beltrán de Urdaneta: «También yo 
A continuación, vamos a exponer ejemplos concretos que hemos ido extrayendo en una tabla que, por su extensión, no podemos aportar en su totalidad. Confiamos en que los ejemplos tomados al hilo de la lectura resulten suficientemente esclarecedores sobre el proceso y producto traductores. En primer lugar, vamos a fijarnos en los antropónimos. De la extensa relación de personajes que aparecen en la novela galdosiana, la traductora elimina sistemáticamente las tildes de nombres de pila y apellidos, así como el signo sobre la letra «ñ», lo que puede tener su lógica, pues, al carecer el alemán de nuestra tilde y de esa letra tan propia del español, mostraría un primer indicio de querer acercar el texto meta lo más posible a la cultura meta, domesticar el texto original, como por ejemplo en: Viscarrués / Viscarrues, Salomé / Salome, Beltrán / Beltran, Griñó / Grinno, marqués de Sariñán / Marquis von Sarinnan. Como vemos, en el caso de la «ñ», el criterio seguido parece haber sido la duplicación de la «n». Sin embargo, no hay un criterio uniforme en ninguno de los dos casos, pues ante el hipocorístico Pepe, en la traducción al alemán aparece Pépé, es decir con dos tildes, o ante el personaje de don Blas de la Codoñera, en la traducción al alemán se ha transformado en don Blas de la Cordonera. Más llamativa resulta la transformación de un personaje histórico tan conocido como $\mathrm{Zu}$ malacárregui, quien en la traducción se convierte en Zumala Carreguin; o que Tena, el cabecilla, se transforme en Tesia, der Chef; el marqués de Castellbell en el Marquis von Castellbello, italianizándose este título de nobleza; o que se produzcan cambios vocálicos, como en el caso de Galán / Galon; Celestino / Celestine, y otros muchos. Este cambio vocálico afecta especialmente a los topónimos, lo que puede producir confusión, en el caso de que el lector, al tratarse de una novela histórica, desease comprobar en un mapa los nombres de los lugares citados por Pérez Galdós en su texto. Además de estos ejemplos de intervención sobre los antropónimos, hay que mencionar que en la novela vertida en alemán desaparecen muchos de los personajes del texto original, como dońa Urraca, Crescencio Marlofa, don Miguel de Córdova, etc. Hasta cierto punto, esto tiene su lógica, pues como hemos mencionado con anterioridad el texto meta es más bien una versión del texto original adaptado a los intereses editoriales.

Por lo que respecta a los topónimos, en algunos de ellos la traductora ha seguido el mismo criterio de eliminación de tildes, y duplicación de la «n» para sustituir a la «ñn, como en el caso de Julióbriga / Juliobriga, Binéfar / Binefar, Alcañiz / Alcanniz, Cariñena / Carinnena. Sin embargo, los cambios vocálicos, consonánticos o, en otros casos, también los calcos salpican el texto meta de principio a fin. Así, por ejemplo, el municipio zaragozano de Fuentes de Ebro se convierte en Ebroquellen, mientras que los cambios, supresiones y adiciones de letras convierten el texto en un galimatías geográfico: Cintruénigo / Cientrenigo, Idiáquez / Idaquez, Teruel / Terruel, Liria / Livia, Cantavieja / Cantaviege, Caspe / Caspa, Ayerbe / Ayerba, Calanda / Calenda, Chestalgar / Chestolgar o, entre otros muchos, Traiguera / Trabiguera. También en el caso de los topónimos,

hace tiempo que he oído hablar sobre su intensa formación humanística, apuntó don Beltrán, pero decidme, ¿qué aspecto tiene Marcela? ¿es bella? Responden sus rasgos y su figura a la proverbial belleza de rompe y rasga de todos los Lucos?». Inmediatamente después hay en el texto original una respuesta de Joreas, cuando en la versión alemana quien habla es Epístola para decir algo que tampoco aparece en el texto original para corroborar la belleza escondida de Marcela, la monja errante que despertaba pasiones entre los paisanos, bajo su hábito de penitente y anacoreta. 
como en el anterior de los antropónimos, algunos desaparecen del texto meta, por ejemplo, Hijar, Canal Imperial, Sariñena o la cuenca baja de Huesca por citar solamente alguno de ellos. Tanto en el caso anterior como en este, hay que ser consciente de las dificultades que la traducción de nombres propios tiene para el traductor, como ya ponía de manifiesto Virgilio Moya (2000), pero el traductor tiene que estar guiado también, y sobre todo, por el sentido común y no desvirtuar estos nombres hasta hacerlos, en algunos casos, lugares o personas irreconocibles, por mucho que la estética traductiva de la época en que se vertió el texto galdosiano al alemán tendiese a adaptarlos a la fonética de la cultura meta.

En el caso concreto de la fraseología, cuando el significado está muy claro, la traductora ha buscado un equivalente bien lingüístico, bien dinámico o cultural, más o menos acertado, sin embargo, lo que prima en este apartado es la supresión. Pérez Galdós recurre a la fraseología con frecuencia para dotar de colorido al texto y acercarlo a la oralidad del pueblo llano. Al no recurrir la traductora a fraseología en alemán que pudiera ser equivalente para las situaciones concretas donde aparece en el texto original, creemos que se pierde uno de los rasgos del estilo galdosiano. Así, desaparecen del texto meta las siguientes expresiones: «más vivo que el azogue», «andar de coronilla», «retirarse con el riñón bien cubierto", "febrerillo loco», "huir de la tremolina», "no dar lumbres», «engolfarse en el juego», "pasar la noche de claro en claro», "Geografía andada, ciencia de los pies», «ver las estrellas», «tomar resuello», «apoltronarse», por mencionar algunos ejemplos. Por el contrario, en otros casos, como hemos dicho, la traductora sí encuentra un equivalente, bien en la propia fraseología alemana o bien recurriendo a la explicación del significado: «ojo por ojo y diente por diente» / Aug um Aug! Zahn um Zahn!, "cabeza más dura que el mármol» / starrköpfig, "todas las cartas me salen buenas» / ich ziehe nur gute Karten, «da quince y raya a las señoras más bien aderezadas» / sie überflügelt alle geschmückten Damen, "haciendo molinetes con el bastón" / er hieb mit seinem Stock in die Luft, "la obligación es antes que la devoción» / Herrendienst geht vor Ritterdienst, «me tienes frita la sangre» / du bringst mein Blut in Sieden, "machacar los huesos de un cristiano» / die Beine eines Christen beschädigen, "con presteza gatuna» / mit der Beweglichkeit wilder Katzen, «más oscuro que la boca del lobo» / finsterer als in einem Ofenrachen, «me da en la nariz» / ich beginne zu unterscheiden, "verde y con asa» / ich dachte mir wohl, "ja buen árbol te has arrimado» / Du hast Dir eine gute Stütze verschafft!, "estaba de Dios» / Es war von Gott bestimmt. Al igual que en los casos anteriores, esos son solamente algunos ejemplos de cómo la traductora resuelve las posibles dificultades fraseológicas en el proceso traductor.

Por lo que respecta a los referentes culturales se produce todo tipo de casuística en las técnicas empleadas. Si traemos a colación lo que sobre las técnicas de traducción recoge Hurtado Albir (2001: 268), a saber, se trata de un «procedimiento, generalmente verbal, visible en el resultado de la traducción, que se utiliza para conseguir la equivalencia traductora [...]", procedimiento que puede tratarse de adaptación, descripción, modulación, transposición, equivalencia, paráfrasis, amplificación, comprensión lingüística, elisión u omisión, préstamo, calco, vemos que el traductor, en este caso traductora literaria, doña Servita, disponía de muchos recursos a su alcance para lograr su objetivo, pero recurrió con profusión a la elisión ante la presencia de referentes culturales. Así, por ejemplo, han desaparecido del texto meta «inmortales sitios», «morrión», «rudeza 
baturra», "la ciudad del Compromiso, la noble Caspe», convertida simplemente en die edle Stadt Caspa, «alazán» que en la traducción no hace alusión al color del caballo, «zaguán», «breñales espesos», "guerra de las Germanías», y un extenso rosario de perlas lingüísticas con las que Pérez Galdós engalana su novela. En otros casos, el referente cultural se ha transformado, sin aparente razón alguna, para buscar un equivalente que no es tal, como sería el caso de la "gótica iglesia parroquial» convertida, nada más y nada menos, en una gotische Kathedrale; más adelante aparece de nuevo la mención a una parroquia gótica de buena y sólida fábrica que la traductora convierte en una sehr solid konstruirte gothische Kathedrale; o la «estatua de bulto» simplemente en una Statue, lo que no identifica si se trata de una escultura en bulto redondo, un altorrelieve, una talla; o la "casona gótica de ojivales porches» ha quedado reducida a ein altes gotisches Gebäude y el «aposento abovedado» en un weiter Innenraum, es decir, un amplio espacio, o la "sala de armas del castillo de San Mateo» en un Wassersaal. Pero no solo tuvo ciertos problemas la traductora con la terminología propia de la arquitectura — que no tenía que saber, a priori, aunque sí saber documentarse-, sino también con los grados de los mandos militares, o con las prendas propias de los trajes típicos, de manera que no aparece en el texto meta la alusión a una «saya de cotolina azul, jubón de pana verde, pañuelo obscuro con fleco, y a la cabeza otro, blanco, sin atar las puntas». La gastronomía popular presentó, asimismo, algunos problemas de comprensión a la traductora, pues en el caso de «Ea, preparad esas migas con prontitud» la traductora ha convertido ese plato propio de pastores en una probable sopa de ajo: Wir waren eben daran, Brod in unsere Suppe zu schneident.

Como hemos podido ver hasta ahora, son múltiples los escollos que la riqueza de un texto de Pérez Galdós plantea al traductor. Sin embargo, estos ejemplos no son nada en comparación con las dificultades que presentan las variantes diatópicas, diafrásicas y diastráticas, ante las cuales la traductora, según nuestro modesto entender, elude todo aquello que le resulta de difícil comprensión. Así, pues, a título de ejemplo, en el texto meta desaparecen términos y expresiones tales como: «chinazo», "un tintillo de Contamina», «no soy más que destrumento», «impedimenta faldamentaria», «calaveradas», mientras que sí encuentra un equivalente, aunque recurriendo a la lengua estándar, en «descarriadico» / so unvorsichtig, "seńá tinienta» / Frau Lieutenant, "caminejo de herradura» / Maulthierstraße, «era el capitán un hombracho hermoso» / Der Kapitän war ein großer, hübscher Junge, "se te quitarán de la cabeza esas murrias de misticismo» / Dein Kopf wird von all diesem Mystizismus befreit werden 5 .

Todas estas decisiones, tanto en un sentido como en otro, obviamente afectan al resultado de la traducción. Se han efectuado sobre unidades microtextuales y cumplen una función concreta. Ante estos ejemplos cabría preguntarse si en la valoración y evaluación de la traducción al alemán de La campaña del Maestrazgo podemos hablar de creatividad o de falta de criterio en el proceso traductor y en el producto resultante del mismo. Cuando los diálogos son muy ricos en variantes diatópicas y en fraseología, se convierten en estilo indirecto y se resume el contenido a manera de relato del autor. Este epígrafe sobre estrategias y técnicas de traducción ante el inimitable estilo literario

4 El significado de la frase por la que optó la traductora es: «En ese momento estábamos cortando pan y echándolo en la sopa», como si se tratase de una sopa de ajo en lugar de unas migas.

5 La traductora optó por escribir «Tu cabeza quedará liberada de todo misticismo». 
de Pérez Galdós lo empezábamos con tres párrafos completos en la lengua original y en la lengua meta, en los que subrayábamos en negrita aquellos posibles problemas que podría plantear la traducción a la lengua alemana y el resultado de las decisiones tomadas en ese proceso versor. A continuación, vamos a ver que la actuación de la traductora no se limitó a unidades microtextuales, sino que se trata en ocasiones de frases enteras, que responden a reflexiones de Pérez Galdós sobre la guerra y sobre el comportamiento humano ante situaciones conflictivas, las que desaparecen en el texto meta. Basten como ejemplo un par de ellas:

1.- «La guerra mata y resucita; destruye y crea. La sangre que no se derrama en los combates, circula con más vigor, y nutre partes desmedradas del organismo social, mientras otras perecen». 2.- «[...] inferiores a lo que exige mi categoría, que tendré que resignarme a ciertas privaciones... Mi principal inquietud es que me corten el paso las tropas de Cabrera o las partidas que, sueltas y desmandadas, infestan toda la tierra de Teruel».

3.- «Allí conoció a Saloma, que, rodando de aquí para allá con borrascosa y turbada vida, después del fusilamiento de su padre en Miranda de Arga, fue a parar a casa de una tía materna, que tenía en arrendamiento tierras de Idiáquez y vivía en una torre próxima al palacio seńorial. Toda esta parte de la historia de Galán y Saloma es algo obscura, y no ofrece bastante interés para que se emprendan, por esclarecerla, investigaciones muy minuciosas».

Quizá las palabras del autor en esta última frase, utilizando un recurso literario, la haya tomado como excusa la supuesta traductora para eliminar todo aquello que en el proceso traductor le debió de parecer oscuro o de significado no bien comprensible. Los Episodios nacionales no son solo una recreación histórica novelada del discurrir y el devenir de España, sino también son, al mismo tiempo, ensayos en los que Pérez Galdós deja traslucir su pensamiento. Así pues, el autor no esconde sus ideas sobre la guerra, sea esta fratricida o contra un enemigo externo. Sin embargo, la supuesta traductora no se adentra en estas reflexiones o, al menos, no las traslada todas, sino muy de cuando en cuando alguna pincelada, como los ejemplos mencionados más arriba. Las reflexiones personales de Pérez Galdós insertas en sus novelas conforman un enriquecimiento del contenido y una marca estilística que al desaparecer en el texto meta consideramos que desvirtúan el estilo del autor. Si bien se dan fluidez y legibilidad, la transparencia a la que Venuti alude en repetidas ocasiones en su texto teórico queda opacada, y oscurecido el autor.

En el epígrafe que hemos dedicado a las razones editoriales para el cambio de título en la cultura meta, nos hemos referido a la diferencia de páginas entre texto original y terminal o meta. La más que drástica reducción en la versión alemana tiene como base la supresión de múltiples párrafos, lo que provoca un desfase en la paginación durante el estudio comparativo-contrastivo entre uno y otro texto. Así, por ejemplo, un párrafo que en texto original aparece en la página 19, tiene su versión alemana en la página nueve:

TO: «Antes de la hora del almuerzo juntáronse el viejo aristócrata y el pintado diplomático en la calle, y cambiando mil finuras, hablaron después cuanto les dio la gana, sin parar hasta que terminó el comistraje» (19). 
TM: «Vor dem Dejeuner trafen sich der alte Edelmann und der Diplomat in partibus auf der Straße, wo sie einander tausend Höflichkeiten erwiesen, und später, während des Frühstücks sprachen sie über allerlei Dinge, die sie interessirten» (9).

En estas mismas páginas desaparecen en la versión en alemán todos los nombres alusivos al devenir de las escaramuzas carlistas en Madrid y la mención a políticos concretos del momento, como Martínez de la Rosa, Quintana y otros. Además de ello, en la versión en alemán se agrupan capítulos. Así pues, no se mantiene la división del texto original. En la mayoría de los casos, no hay correspondencia entre el comienzo y el final de los capítulos. Solamente en algunas ocasiones coincide el contenido al comienzo de un capítulo en la lengua original y en la lengua meta, aunque la numeración de los capítulos sea diferente. Así, el capítulo XI en el texto original, es el capítulo tercero en el texto meta.

Páginas enteras desaparecen del texto traducido, trayendo al primer plano la teoría de las «bellas infieles». En consecuencia, podemos afirmar que se trata más bien de un texto inspirado en La campaña del Maestrazgo, de Pérez Galdós, reconvertido en novela de una monja, y lo que la supuesta traductora considera superfluo para la historia lo elimina, bien por iniciativa propia o a instancias de la editorial. Ejemplos palpables de supresión de frases enteras o incluso de párrafos son aquellos que, por su contenido, parecen no interesar al decurso de lo narrado en lengua alemana, y que además contienen referentes culturales que, como hemos visto, se eluden frecuentemente en la traducción. $\mathrm{Ni}$ siquiera recurre a técnicas como la explicitación o la ampliación de significado. Un caso concreto de elisión durante el proceso traductivo sería el siguiente «A mí no me hable usted de gente levítica — dijo, recalcando esta palabra, que recientemente había adquirido en la tertulia de la botica de Cornejo- - Tengo declarada la guerra a esas ideas rancias, tan contrarias al espíritu del siglo», fragmento que no aparece en el texto meta. Entre los párrafos desaparecidos del texto terminal hay descripciones de tanta belleza plástica como uno alusivo a la entrada en la bella población turolense de Alcañiz:

\begin{abstract}
«A la luz crepuscular, los esquinazos góticos y mudéjares parecían bastidores de teatro, dispuestos ya, con las candilejas a media luz, para empezar el drama. Resonaban las herraduras de los caballos en el pedernal de las calles levantando chispas, y el ruido de tambores jugaba al escondite, sonando aquí, apagándose allá, en los dobleces de la edificación, y volviendo a retumbar a retaguardia de la tropa. Las plazuelas se unían por pasadizos, y las calles se retorcían unas sobre otras, obscuras, ondulantes. Soldados y algunos viejos se veían discurriendo por las calles; mujeres en algunas puertas... Triste y belicosa parecía la ciudad, como un guerrero herido que se ve forzado a combatir con la mano que le queda» (1900: 24).
\end{abstract}

Las prolijas descripciones paisajísticas de Pérez Galdós constituyen un auténtico recreo para el lector hispanoparlante, recreo del que no goza el lector en lengua alemana de esta obra. Así, por ejemplo, la llegada a Burjasot de las tropas carlistas la describe Pérez Galdós del siguiente modo: 
«Burjasot, lugar cercano, para verla al menos y que ella le viese. Aunque de escaso relieve, la eminencia en que está fundado aquel pueblo es como atalaya que domina la huerta feracísima, y a lo lejos el apretado caserío de la ciudad, guarnecida del verdor perenne de los naranjos, y destacando sus torres y chapiteles sobre una espléndida faja de mar azul» (1900: 56, cap. XIV).

Esta descripción la traductora la despacha con: «er schlug sein Lager in dem benachbarten Burjasot auf» (1902: 5, cap. 4), es decir «montó su campamento en la cercana Burjasot». Así pues vemos que aunque el contenido del texto original sí aparece en el texto meta, está drásticamente resumido, como en este otro ejemplo:

\begin{abstract}
«Pasado el puente, avanzaron buen trecho por una alameda interminable; y como levantara la bruma, el teniente hizo notar la gallardía de los desnudos álamos del paseo, y mirando hacia atrás, la hermosa vista de la ciudad, coronada por el castillo y ceñida por el Guadalope. Sin enterarse bien, manifestó D. Beltrán su admiración, pues no gustaba de dar a entender que veía poco» (1900: 26, cap. VII).
\end{abstract}

Ante esta descripción de Pérez Galdós, en la versión en alemán solamente se dice que don Beltrán y el oficial abandonaron la ciudad, atravesando el puente sobre el río Guadalope: "Don Beltran und der Offizier verließen über die Guadalopebrücke die Stadt» (1902: 1, cap. 2).

Otro aspecto a tener en cuenta es el relativo a la puntuación, lo que conduce, en ocasiones, a un cambio de significado. En algunos casos, lo que en el texto original es una pregunta: «¿Viene con ellos una señora vestida de monja o penitente?» (1900: 33) se convierte en una exhortación en el texto vertido al alemán: «Kommen Sie mit einer Frau, die als Nonne oder Büßerin gekleidet ist'’ (1902: 5, cap. 2).

\title{
4. REFLEXIONES SOBRE LA CALIDAD DE LA TRADUCCIÓN A LA LUZ DE LOS TEÓRICOS
}

La pasión por Pérez Galdós y el disfrute que proporciona su pacto de lectura con los destinatarios de sus textos, a los que llama de vez en cuando para que se adentren en el desarrollo de la trama y se vean parte de la panoplia de personajes, como cuando escribe: «Entrando en conversación la hermosa mujer, en quien habrá reconocido el lector a... » (1900: 4) o cuando reflexiona e invita al mismo tiempo al lector a reflexionar con él, como ante la siguiente afirmación: «No es tan gran autoridad el virtuoso que nunca ha pecado como el pecador que reconoce, aunque tarde, sus yerros» (1900: 99), nos conduce, quizá, a valorar negativamente una versión en lengua alemana tan distante y distinta de la lengua original como hemos tenido ocasión de comprobar a lo largo del estudio comparativo.

Sin embargo, surgen matizaciones en la valoración a la luz de las reflexiones y presupuestos teóricos de autores como Nida y Taber (1986: 18-20), por ejemplo, cuando afirmaban a propósito de las actitudes ante las lenguas receptoras:

«[... si los traductores quieren conseguir unos textos que produzcan en sus lectores una respuesta equivalente a la que produjeron los originales, nece- 
sitan cambiar sus puntos de vista sobre las lenguas con que trabajan. Esto exige, por una parte, dejar de poner las lenguas originales en un pedestal teológico y de doblegarse ante ellas con una sumisión ciega [...] cada lengua tiene su genio particular [...]. En vez de forzar la estructura formal de una lengua con elementos ajenos a la misma, el buen traductor está dispuesto a hacer todos los cambios formales que sean necesarios para reproducir el mensaje de acuerdo con las formas estructurales propias de la lengua receptora [...]. Si todas las lenguas tienen formas diferentes, es obvio que haya que cambiar las formas para conservar el contenido [...]».

Por otro lado, cuarenta años antes que Nida y Taber, Hermann Broch (1948, en Vega 1994: 310-323), a propósito de la primera destreza que debía tener un traductor, nos plantea la disyuntiva de considerar o no a la supuesta traductora de La campaña del Maestrazgo al alemán, «Doña Servita», como una traductora competente, pues la lectura de la versión alemana, sin lugar a dudas, tiene algunas carencias que incluso el lector de lengua y cultura alemanas captaría.

«[... A pesar del imperativo reconocimiento del elemento irracional e intuitivo, es una exigencia absolutamente racional que el traductor entienda suficientemente bien el idioma del que traduce para comprender el sentido de sus frases. Y esto es precisamente lo que tiene que traducir, pues no traduce palabras u oraciones, sino los contenidos de sentido. Si comprende el sentido de la frase que debe traducir, tendrá que trasladarla a la lengua de recepción en la que se tiene que sentir como en su casa. Él expresa este sentido en la lengua de traducción como si no existiera un original [...]».

Hemos dicho con anterioridad que la versión en alemán, drásticamente reducida, como hemos podido comprobar en numerosos ejemplos traídos a estas páginas, respondía a los presupuestos mercadotécnicos de la editorial. Así pues, es de suponer que la traductora debía ajustarse a la función que ese texto pretendiera producir en el polisistema cultural de llegada. Si nos atenemos a la teoría funcional de la traducción, y atendemos las afirmaciones de Reiss y Vermeer (1996: 80-84), podríamos decir que la versión en alemán es precisamente eso, una versión, inspirada en el texto original y que cumple su función:

«[...] El principio dominante de toda traslación es su finalidad [...]. El emisor puede valorar cada una de sus acciones partiendo de su intención (la función pretendida) y el receptor puede valorarlas partiendo de su interpretación (la función interpretada) [...] Es más importante que un translatum (una traslación) alcance un objetivo dado, que el hecho de que se realice de un modo determinado [...] Por tanto, no existe la única forma de realizar una traducción de un texto; los textos meta varían dependiendo del escopo que se pretende alcanzar $[\ldots]$ ».

Sin embargo, ante un autor de la talla de Pérez Galdós, consideramos que la editorial hubiese tenido que hacer la advertencia previa de que se trataba de una novela «inspirada en...» $\mathrm{o}$ «recreada en...». La teoría de la traducción permite múltiples licencias al traductor 
para cumplir su objetivo y que este cumpla la función prevista. A pesar de ello, creemos que no todas las decisiones de supresión o elisión son válidas, pues, de acuerdo con Hatim y Mason (1995: 23-24): «[...] Para traducir hay que elegir, pero toda elección está motivada; todo puede justificarse: omisiones, adiciones y alteraciones, pero solo en relación con la intención significativa [...]». Como hemos visto en el caso de la traducción al alemán de esta obra galdosiana, no siempre creemos que estuvo justificada la omisión de términos concretos, ya se tratase de referentes culturales, fraseología, variantes lingüísticas, personajes o lugares geográficos. Otro asunto bien distinto es - lo que no quiere decir que lo justifiquemos - la supresión de párrafos y páginas enteras para que el texto meta, inspirado en el original, cumpliese su objetivo, lo que nos acercaría a afirmar que en el caso de la traducción de La campaña del Maestrazgo al alemán estaríamos ante un ejemplo paradigmático de la teoría de las «bellas infieles».

\section{CONCLUSIONES}

A la luz de la traducción en lengua alemana de La campaña del Maestrazgo, podemos afirmar que el intento de la supuesta traductora de ocultar su nombre, de invisibilizarse ante el lector meta, no la convirtió en una venutiana traductora invisible, sino más bien al contrario, ya que el estudio comparativo entre la lengua original y la meta muestra claramente la intervención de la traductora. Por lo que respecta a la estrategia de extranjerización o de domesticación, consideramos que la traductora ha optado por esta última, sin lograr plenamente la legibilidad y la fluidez por las que aboga Venuti.

El argumento y los protagonistas de la novela no varían en la traducción al alemán, aunque sí es cierto que, como ya hemos apuntado con anterioridad, una gran parte de los personajes secundarios, así como sus acciones, desaparecen en el texto meta, siendo esta una de las razones de la drástica reducción del texto en la versión alemana.

La rica adjetivación de Pérez Galdós se pierde indefectiblemente en la versión al alemán. Así, la «abundosa y pintoresca verbosidad», expresión que el autor emplea en algún momento de su novela para caracterizar la riqueza en el habla del pueblo, desaparece en la traducción, ofreciéndonos la supuesta traductora un texto interesante, aunque plano desde el punto de vista estilístico.

En el estudio comparativo realizado entre el texto original y el texto meta se puede hablar en algunos casos de creatividad en las soluciones, sin embargo, lo que prima en la mayoría de las ocasiones es una falta de criterios uniformes en la toma de decisiones y en las técnicas utilizadas, especialmente por lo que respecta a los referentes culturales, aunque no solo.

La comparación entre texto original y texto meta nos conduce también a una afirmación sobre la recepción de la obra en lengua alemana, y esta es que no se tradujo en su totalidad, sino solo fragmentariamente debido a intereses fundamentalmente editoriales, lo que no obsta para reconocer el valor que en su momento tuvo la introducción de Pérez Galdós en ese mercado en lengua alemana que editaba obras de otros polisistemas culturales en Alemania, Austria y Hungría, como fue el caso de la editorial Sachs \& Pollack.

Consideramos que la introducción de un autor de la talla de Pérez Galdós en otros países europeos, y concretamente en los de lengua y cultura alemanas, partiendo de 
obras fragmentadas, reducidas o, simplemente, inspiradas en el original es una práctica editorial que sufre mermas que pueden tardar años en subsanarse y dar a conocer a un autor literario de prestigio en toda su dimensión. De hecho, hasta la década de los ochenta del siglo pasado no ha habido en el mercado editorial en lengua alemana traducciones de algunas novelas de los Episodios Nacionales consideradas de alta calidad (Vollmann 1998). Por lo que respecta a la novela analizada, La campaña del Maestrazgo (Der Roman einer Nonne), no ha habido nuevas traducciones desde que se publicara en alemán en 1902, sino solamente reimpresiones en editoriales que imprimen bajo pedido. 


\section{CAPÍTULO IV}

\section{La obra de Pérez Galdós en las traducciones italianas}

Assunta Polizzi

Università degli Studi di Palermo

\section{INTRODUCCIÓN}

Este estudio se propone recuperar y organizar el panorama de las traducciones al italiano de la producción de Benito Pérez Galdós, con la finalidad de individualizar los factores editoriales y culturales relevantes en el proceso de hilvanado de las diferentes etapas de la recepción italiana del gran escritor naturalista español. ${ }^{1}$

A partir de la traducción en 1874 de La fontana de oro (1870) a cargo de Federico Pozzani (La fontana d'oro), publicada en Milán por la Editorial Treves, la recepción italiana de la amplia producción de las obras de Benito Pérez Galdós a través de las traducciones no presenta un panorama muy satisfactorio, sino más bien desigual y hasta contradictorio (Ottaiano 2013; Paz de Castro 2018). De hecho, a un temprano interés editorial por la publicación de traducciones contemporáneas del escritor canario o en las décadas inmediatas a su fallecimiento, seguirá un periodo emblemático —enmarcado en el Ventennio fascista - relacionado sobre todo con la reiteración de las ediciones de Misericordia por parte de una larga lista de editoriales italianas, además de un caso representativo de manipulación combinado con un ejemplo de traducción muy parcial, es decir, el de la así llamada primera traducción al italiano de la obra maestra galdosiana, Fortunata e Giacinta. Storia di due donne maritate, de 1926, por la editorial Salani de Florencia y por obra de la traductora palermitana de adopción, Silvia Baccani Giani. Se trataba, en todo caso, de la primera traducción a un idioma extranjero de Fortunata y

1 Las fuentes esenciales para este estudio han sido los catálogos de la Biblioteca Nazionale di Roma y de la Biblioteca Nazionale di Firenze, además del de la Biblioteca Centrale della Regione Siciliana. Se han consultado, además, algunos de entre los muy escasos repertorios bibliográficos de traducciones, que proceden de proyectos de investigación, como el proyecto PRIN 2008, «Relazioni intertestuali fra Spagna e Italia: riscritture e traduzioni» coordinado por Giulia Poggi; el proyecto que se ha dedicado al siglo XIX «Per un censimento delle traduzioni in italiano nell'Ottocento», coordinado por Stefano Ondelli y Paolo Ziani (Ondelli, Ziani 2013) y el proyecto «Iride 900. Indice delle Riviste Italiane del '900» coordinado por Giorgio Barone (Barone 2014). No obstante, todavía falta en Italia una sistematización completa de las obras extranjeras vertidas al italiano. 
Jacinta, ya que la versión alemana no se produciría hasta 1961; la francesa, en 1970, y la inglesa, en 1973. Después de casi un total vacío en los ańos de la inmediata posguerra, los 40 y 50, las siguientes décadas conocerán diferentes traducciones de Trafalgar y de Tristana y - debido a la prescripción de los derechos de propiedad intelectual de la obra de Galdós- los años 2000 abren un territorio interesante, ya que se intentan difundir, por medio de la traducción, novelas galdosianas fundamentales, aunque desconocidas para los lectores italianos. Sin embargo, notables ejercicios traductológicos —a menudo acompańados por oportunos aparatos paratextuales - no encontraron gran acogida entre las grandes editoriales nacionales que pudieran garantizar su difusión comercial de forma amplia y rentable.

Por lo tanto, y grosso modo, este panorama presenta la intención de trazar las huellas de la recepción italiana de la obra galdosiana a través de sus traducciones, a partir de la apuesta de la editorial Fratelli Treves de Milán sobre un joven Galdós que hacía «los primeros pinitos, como decirse suele, en el pícaro arte de novelar» ${ }^{2}$ (Galdós 1890: 6). La editorial milanesa llevaba poco más de una década de actividad desde su fundación en 1861 por Emilio Treves; sin embargo, pronto se había convertido en un importante referente para la cultura italiana. No solo porque editaba a los escritores más relevantes del ámbito nacional, o incluso internacional, como Verga, De Amicis, D’Annunzio, Pirandello, etc., sino también porque se dedicaba a consolidar la recepción del canon literario universal a través de traducciones de las obras de autores consagrados como Tolstói, Flaubert, las hermanas Brönte, o Dickens, entre otros. Con este plan editorial, que también buscaba colaborar en la unificación lingüística de una Italia recién nacida políticamente, al mismo tiempo que formar a lectores de diferentes sectores sociales, la editorial Treves creó numerosas colecciones de muy variado alcance cultural y muy diverso público de lectores, sin olvidarse de otorgar una constante y relevante atención a ensayos y novelas traducidas de otras lenguas (Zaccaria 1984).

Hay que recordar que, como en otros países, también en Italia las obras del siglo XIX -sobre todo aquellas escritas en idiomas menos conocidos como el ruso- se vertían al italiano empleando la traducción francesa como texto intermediao. Aparte, la literatura europea contemporánea se leía en Italia directamente en francés, puesto que amplios sectores del público lector conocían este idioma. Sin embargo, en las primeras décadas del siglo XX, el aumento del precio de las novelas de importación obligó a los editores italianos a elegir un tipo de producción no mediada por el mercado francés. Los efectos positivos de tal necesidad de ahorro coincidieron con un importante desarrollo de la actividad de traducción directa hacia el italiano, la cual fue especializándose cada vez más y - en el caso de la praxis hispano-italiana - a menudo estuvo a cargo de grandes estudiosos hispanistas (Ballesteros Dorado 2017).

$\mathrm{Al}$ mismo tiempo, fue consolidándose una inevitable reflexión teórico-traductológica o, por lo menos, fue creándose una conciencia de la compleja relación entre prototexto

2 La cita procede del prólogo de Galdós a la edición en volumen de La sombra junto a los relatos «Celín», «Tropiquillos» $\mathrm{y}$ «Theros» de 1890, y se refiere, en forma de captatio benevolentiae, precisamente al periodo juvenil de su escritura, alrededor de 1866-67, en el cual se situaría la primera composición narrativa del escritor canario, La sombra. De hecho, la obra se publicará más tarde y por entregas en la Revista de España, entre el 28 de enero y el 28 de febrero de 1871. Así que es posible afirmar que la primera obra que Galdós publicó fue La fontana de oro, en 1870 . 
y metatexto, no gobernada exclusivamente por cuestiones estrictamente lingüísticas, sino más bien culturales. Ejemplos de ello son las indicaciones, en la misma portada, de eventuales «autorizaciones de traducción» por parte de los autores originales, o la presencia de paratextos, sobre todo prólogos, a cargo de dichas figuras literarias y dirigidos al nuevo público de lectores, pero también comentarios justificativos y explicativos firmados por los traductores o, incluso, los editores, los cuales muestran sentirse responsablemente implicados en el proceso cultural que subyace a la recepción de una obra en traducción. Así fue en el caso de las traducciones publicadas por editorial Treves. Ambrella (2011) recuerda en su estudio algunos paratextos que los traductores o este mismo editor milanés, Ricardo Treves, anteponen, por ejemplo, a los ensayos de la colección Biblioteca Utile de su editorial del mismo nombre. Ambrella reproduce, por ejemplo, las mismas palabras que nuestro editor escribe en la «Nota» a la segunda edición de 1866 de Chi si aiuta Dio l'aiuta (1865), traducción de la obra de Samuel Smiles Self-Help: with Illustrations of Conduct and Perseverance, de 1859. En este caso, se subraya la reflexión bastante moderna del uso dañino de una excesiva «domesticación», al tiempo que se enfatizan los procesos de adaptación y hasta de atrevida interpretación del original que la traducción francesa de la misma obra patentiza, junto a una presencia muy «visible» del traductor, todo lo cual alejaría al nuevo lector del texto de las coordenadas culturales del ambiente de procedencia, en este caso el de Inglaterra:

\begin{abstract}
"Chi si faccia a confrontare la nostra traduzione con la francese, vi troverà un grandissimo divario, che vogliamo essere primi ad avvertire. Certamente l'autore inglese si soffermò con singolare compiacenza a citare esempi inglesi; non oseremmo sentenziare se ciò sia un difetto, vista la natura del libro; ma che dire del traduttore francese che alla sua volta surrogò in gran parte gli esempi dell'originale con esempi francesi? (...) il fatto è che il libro nella versione francese è per così dire travestito in gran parte. Anche a noi sarebbe stato forse non difficile fare la stessa operazione per l'Italia; ma abbiamo stimato meglio restringerci a qualche nota, e non far perdere l'impronta originale all'opera" (Ambrella 2011: 8).
\end{abstract}

Es en este fértil ambiente editorial, en el cual «il pubblico di Treves andrà quindi ricercato, di preferenza, in una fascia medio e altoborghese, cui si rivolge l'establishment della politica culturale» (Zaccaria 1984: 26), se inserta tempranamente, en 1874, la primera obra de Galdós traducida al italiano, La fontana d'oro, vertida por Federico Pozzani e incluida en la colección Biblioteca Amena. Este autor-traductor había empezado a colaborar con la editorial milanesa en 1873, cuando había publicado Maria la graciosa, de Fernán Caballero, y seguirá al año siguiente, 1875, con una novela de Juan Nombela, La carrozza del diavolo.

En las siguientes secciones, tendremos en consideración todo lo subrayado hasta este momento, en especial, el proceso irregular que ha marcado siempre la traducción y la recepción italiana de las obras de Galdós. Para ello, se ha elegido un criterio cronológico, que pueda dar constancia, de forma más directa, de todas las cuestiones relacionadas con los factores culturales y los códigos hegemónicos de la época en la que se producen, o no, dichas traducciones. 


\section{Periodo contemporáneo a Galdós}

La primera etapa, por lo tanto, es la contemporánea al autor y podría enmarcarse entre 1874 y 1907 , teniendo en cuenta — por los datos recogidos hasta el momento- las fechas de la primera y última obra galdosiana publicadas traducidas en Italia dentro de este periodo. Entretanto, como se ha ido subrayando, la prensa desarrolla un importante papel en el proceso traductivo-divulgativo (Freire López y Ballesteros Dorado 2017; Paz de Castro 2018), aunque en mayor medida respecto al género de la poesía, por comprensibles razones de espacio en la página del periódico, además de la posibilidad de ofrecer el texto en su totalidad en un único momento de lectura. Sin embargo, también se pueden encontrar, en revistas especializadas, textos de narrativa publicados por entregas. Es el caso de las ediciones en prensa que siguieron a La fontana de oro de 1874, versión casi no citada en los escasos listados y estudios que se han dedicado al tema (García Bolta 1993: 45). De hecho, vuelve a imprimirse por entregas en 1878 (febrero-abril) en la revista milanesa La Ragione. Giornale della Democrazia. Con referencia a este tema y con firma de Eugenio Fabris, se guardan dos cartas en el epistolario galdosiano de la Casa-Pérez Galdós: ${ }^{3}$ la primera, fechada en Milán el 24 de octubre de 1877, en la cual Fabris anuncia a Galdós su proyecto de publicar La fontana de oro en esta publicación de ideología democrática en forma de folletín y pide para ello el permiso por parte del autor. En la segunda carta, Milán 17 de enero de 1877, Fabris expresa con entusiasmo su gratitud a Galdós y anuncia la próxima publicación de la novela, así como su siguiente proyecto de traducir Gloria, del cual, sin embargo, no se ha encontrado confirmación en los catálogos bibliográficos. En todo caso, como se indicará más adelante, la primera versión de esta última novela autorizada por el autor será la de Italo Argenti, aunque quede siempre la posibilidad de que la de Fabris se publicara por entregas en algún rotativo. De hecho, dos cartas más del epistolario galdosianos se encuentran relacionadas con este asunto. ${ }^{4}$ Son las que dirige a Galdós, con membrete de la misma publicación milanesa La Ragione, el intelectual peruano Rómulo Cúneo y Vidal, que firmaba también sus artículos y obras literarias con el seudónimo de Juan Pagador. Este se encontraba por entonces de estancia en Italia ejerciendo el oficio de redactor, después de haber transcurrido sus años de formación entre Inglaterra y Francia. La primera carta, fechada en Milán el 4 de enero de 1879, da cuenta del éxito de público del folletín de La fontana d'oro, una «revelación», en palabras del remitente, el cual define la obra como una «misión de progreso", después de haber subrayado que la literatura española todavía seguía siendo en Italia, como en otras partes, desconocida o mal apreciada. Por lo tanto, la carta se cierra con la petición al escritor canario, de otras novelas que el mismo Cúneo y Vidal se ofrece traducir. La segunda carta, fechada el 14 de febrero de 1879, en respuesta a la que tuvo que enviarle Galdós, vuelve al mismo tema, reiterando el triunfo de La fontana d'oro e informando que se estaba publicando también en Nápoles en $I l$

3 Gracias al Proyecto "Galdós-pedia 2020. Epistolario digital», coordinado por Yolanda Arencibia y en el cual colaboro, he podido visionar y estudiar el material epistolar guardado en la Casa Pérez-Galdós. Quiero expresar mis agradecimientos a todo el equipo investigador y especialmente a la profesora Arencibia y a Rubén Domínguez.

4 Están fechadas las dos en Milán, el 4 de enero de 1879 y el 14 de febrero de 1879, respectivamente. 
Pungolo. Giornale Político Popolare della Sera. ${ }^{5}$ Después de disculparse por no poder satisfacer el deseo que le había expresado Galdós de poder leer su novela en el folletín italiano, debido a la dificultad de encontrar los textos de los periódicos al cabo de cierto tiempo de haber salido a la calle, como en este caso, Cúneo y Vidal aprovecha la oportunidad para expresar su juicio negativo acerca de la «infeliz traducción» de La fontana, intuyendo en ella sobre todo mutilaciones y modificaciones que afectarían la estructura general de la obra, e incluso el desenlace. Se trata de intuiciones puesto que, como confiesa, no ha tenido la oportunidad de leer el texto en la lengua original ni, por lo tanto, de compararlo con esta versión italiana. ${ }^{6}$ Acto seguido, se ofrece a «corregir» la traducción, confrontándola con la obra original, para publicarla luego en el formato 'serio' de un libro. Pide, por lo tanto, la autorización del autor y asegura querer respetar lo literario de la novela, así como los derechos de la propiedad intelectual del autor:

«Sería, de publicar, después de corregida y confrontada al original aquella traducción, no más bajo forma de folletín, mas bajo la forma más seria de libro. Si Ud. me diera su autorización para este paso yo la haría con el mayor gusto, con la conciencia de que los méritos literarios de la obra no fueran menguados por la traducción y además sus derechos de autor serían, como es natural, satisfechos. Si Ud. acepta, tenga Ud. la bondad de significármelo y de mandarme el tomo de la Fontana» (Cúneo y Vidal 14.02.1879).?

La carta se cierra con un humilde reconocimiento acerca del empobrecimiento que probablemente detectaría en su castellano el escritor, puesto que los ańos pasados en el extranjero y los cinco idiomas que declara conocer han hecho que fuera precisamente la lengua de su país la que menos dominara. Finalmente, la editorial Treves volverá a editar una nueva traducción de La fontana de oro en 1890, por obra de Giacomo Demichelis.

En 1880 se presenta al público italiano Marianella, traducida por el mismo Demichelis, y editada por la Tipografia Pontificia Mareggiani de Bolonia. Entre las cuatro epístolas del traductor italiano que se guardan en la Casa-Museo, la fechada en Turín el 2 de octubre de 1880, dirigida al director de La Guirnalda, acompaña precisamente el envío de 4 ejemplares de la obra. Según se lee en la carta, Demichelis se disculpa por el retraso de la publicación, puesto que había recibido la autorización para traducir Marianela dos ańos antes y, por razones de salud, no había podido respetar el plazo estricto de un año que Galdós solía imponer, como se puede leer en la carta que el escritor dirige a otro traductor italiano, Francesco M. Gelormini y que Elena de Paz de Castro (2018: 832) reproduce en su reciente y puntual estudio sobre las traducciones y las referencias a Galdós en la Italia contemporánea al autor. Parece que la firme intención de Demichelis

5 Fundado por Leone Fortis en Milán en 1858 y luego impreso también en Nápoles a partir de 1860, parece plausible que tal relación entre el ambiente milanés y el napolitano propiciara una reedición en 1979 de la misma traducción de Fabris.

6 A juzgar por el muy escaso español de las cartas de Eugenio Fabris a Galdós, es posible compartir el juicio de Cúneo y Vidal. Nos reservamos profundizar en el tema en un próximo estudio de análisis traductológico para el cual se están recogiendo, aunque no sin dificultad por lo que se refiere más bien a publicaciones en prensa, todos los textos en traducción italiana de las obras de Galdós.

7 Lo subrayado está en el texto. 
era publicar la obra en un ambiente editorial decididamente católico, aunque, según escribe en la carta, «no pude lograr que mi traducción viera la luz en los apéndices del Emporio populan» (Demichelis 2.10.1880), periódico católico fundado en Turín en 1873 y dirigido por el jesuita Enrico Vasco. La elección editorial determinará, por lo menos, las coordenadas culturales de la primera recepción de la novela, así como la admisión de haber adaptado el texto al "gusto italiano» con unas "pequeñas cortaduras» (Demichelis 2.10.1880).

La editorial Fratelli Treves en 1907 editará la traducción de esta novela de «la primera época» junto a la primera versión al italiano de Trafalgar, en la célebre colección Biblioteca Amena. ${ }^{8}$

La familia de León Roch (1878) aparece, entre agosto y noviembre de 1883, en el periódico La Perseveranza. Giornale del Mattino, traducida por Daniele Rubbi y titulada La famiglia di Leone Roch. Se trataba de un diario conservador fundado en Milán el 20 de noviembre de 1859 por una pareja de intelectuales de la derecha liberal, Pacifico Valussi y Ruggero Borghi, y que pronto se convertirá en uno de los referentes culturales italianos también respecto al arte y a la literatura. Rubbi desarrolla su actividad de redactor durante varios años en el periódico y, sobre todo, fue traductor de varias obras españolas de Alarcón y de Valera, algunas de las cuales fueron publicadas también en forma de folletín en La Perseveranza (Ballesteros Dorado 2017). El epistolario galdosiano guarda también la carta firmada por Daniele Rubbi, fechada en Milán el 16 de julio de 1883, escrita en italiano a pesar de la larga experiencia con la lengua castellana ( «Io ho tradotto quasi tutti i lavori del vostro illustre Valera, della cui amicizia mi onoro, e molti altri volumi di noveleros spagnuoli; ora voglio tentare una commedia di don José Echegaray del vostro teatro», ${ }^{9}$ (Rubbi 16.07.1883) con la cual el traductor pide precisamente a Galdós «il permesso» de traducir la novela que define como «uno dei più bei racconti che siano usciti in questi ultimi tempi» (Rubbi, 16.07.1883). Finalmente, como nota traductológica entre las líneas de la carta, resulta interesante -sobre todo porque no se ha encontrado en los documentos epistolares galdosianos de parecida naturaleza- el reconocimiento del provechoso diálogo entre traductor y autor que ya Moimónides, en 1199, expresaba en las epístolas a su traductor Tibón, cuyo nombre esta colección homenajea. De hecho, Rubbi escribe en el cierre de la carta: «In pari tempo la prego qualora trovassi qualche difficoltà nella traduzione - di permettermi che le chieda qualche consiglio» (Rubbi 16.07.1883).

8 En el programa divulgativo-cultural de la editorial Fratelli Treves, del cual ya se ha hablado, esta colección se hizo muy famosa también por la campaña publicitaria que la acompañó, donde se la solía llamar «Biblioteca Amena a una lira». Siguió publicando un gran número de obras traducidas entre 1875 y 1913, por un total de 893 volúmenes. En una de las secciones de los anuncios editoriales de un libro se puede leer: «Se le raccolte economiche di romanzi a una lira destano in genere i sospetti delle persone delicate, questa ha saputo con una scelta giudiziosa ed eclettica, al tempo stesso non alienare i gusti volgari e allettare i più raffinati. (...). La BIBLIOTECA AMENA è stata la prima a far conoscere al pubblico italiano il Daudet, il Flaubert, lo Zola, il Bourget, il Maupassant, il Rod, nonché i classici Goethe e Balzac, e i romanzieri russi (Tolstoi, Dostojewski, Turghenieff, Gorki), ed altri tedeschi ed inglesi. (...) gli spagnoli Perez Galdos [sic], Valera, De Alarcon [sic] (...)». (Werner 1913: s. p.)

9 Lo subrayado está en el texto. 
En 1892, el mismo periódico La Perseveranza vuelve a interesarse por la obra de Galdós, en general, y por Doña Perfecta (1876), en particular, por lo que publica por entregas, entre junio y julio de 1892, Donna Perfetta, «versione dallo spagnuolo di Irma Rios». Dos años después, en la primavera de 1894, la misma novela aparece en la colección Corriere delle Puglie de Bari, con la traducción a cargo de Diana D’Alteno y con el título La signora Perfetta. Sin embargo, finalmente, esta novela galdosiana, una de las de mayor fama internacional entre las suyas, encuentra su adecuada plasmación editorial en forma de libro en la editorial Fratelli Treves en 1879, aunque sin indicación del nombre del traductor. Sin embargo, entre los anuncios de la reedición de Bailén de 1904 por Perlado, Páez y Compañía (Sucesores de Hernando), se incluye una sección de información sobre las traducciones de obras de Galdós y, en el apartado "En italiano" aparece lo siguiente: «Doña Perfecta. Traducción de Cunes. Milán. Fratelli Treves. 1897». Puesto que no se ha encontrado ninguna información acerca del tal "Cunes" sin más, se formula la hipótesis de que podría tratarse de Rómulo Cúneo y Vidal, cuya voluntad de traducir textos galdosianos ya se ha recordado al tratar su correspondencia con Galdós.

También Gloria (1877), entre la producción galdosiana de la década de los 70, se editará en traducción italiana, Gloria. Romanzo contemporaneo, en 1901, por la editorial florentina Enrico Bemporad. Esta era empresa de gran relevancia en el panorama cultural de la época, sobre todo por las colecciones dedicadas a la literatura infantil y juvenil, además de escolástica, hasta su desaparición a raíz de las Leggi raziali de 1938. Enrico tuvo que dejar la editorial, que adoptó el nombre de Edizioni Marzocco, como la célebre revista literaria florentina de comienzos del siglo XX, pasando luego a integrarse, en 1956, en el grupo editorial Giunti. El volumen presenta la nota aclaratoria siguiente: «Prima traduzione italiana dallo spagnolo autorizzata dall'autore», así como el nombre de su traductor, Italo Argenti.

$\mathrm{Al}$ año siguiente y también en Florencia, la editorial Nerbini publica Nazarín (1895), con autorización previa a la traducción del autor concedida al escritor y traductor también del francés Guido Rubetti y al dramaturgo, ensayista y pintor argentino José León Pagano, con el título Sicut Christus. Romanzo contemporaneo. Ballesteros Dorado recuerda que esta obra de Galdós había ya conocido en Italia «dos impresiones sin mención a la autorización del autor y sin el nombre del protagonista, nombre que se añadiría a partir de la tercera edición» (2017: 50), es decir, la de Nerbini de 1902. Como prueba del éxito que tuvo la obra en Italia, resulta interesante que de ella hablara también Giovanni Papini, el intelectual florentino estudioso de filosofía y religión que contribuyó activamente al rejuvenecimiento de la cultura italiana a caballo entre los dos siglos, en su epistolario con el amigo y cofundador de la revista Leonardo Giuseppe Prezzolini:

«[Firenze] 7 giugno 1902.

Ma in questi giorni, al solito, ho letto poco, fra l'altre cose un romanzo del Perez [sic] Galdós "sicut Christus", curiosa miscela di Vangelo, di Tolstoi, di "Don Quijotismo" e di realismo spagnolo. Gianfalco».10 (Gentili, Manghetti 2003: 147)

10 «Gianfalco» era el seudónimo con el que Papini firmaba sus artículos en Leonardo. 
Entretanto, el 30 de enero de 1901, en el Teatro Español de Madrid tenía lugar el celebérrimo estreno de Electra y, unos meses más tarde, el 24 de abril de 1901, la compañía Mauri representa en el teatro Manzoni de Roma una Elettra traducida y adaptada por Enrique Tedeschi. Este mantuvo una actividad continuada vertiendo y adaptando obras teatrales italianas al escenario español en colaboración, sobre todo, con Antonio Fernández Lepina, como los arreglos de Quello che non ti aspetti, de 1922 (Lo que no te esperas, 1923), por Luigi Barzini y Arnaldo Fraccaroli o Parodi e C., de 1926 (Parodi y Cía, 1929), por Sabatino Lopez. Una reseña de la primera representación en Italia de Elettra se publicó en la Rivista Teatrale Italiana en el mismo año, firmada por Luigi Grande. El juicio del reseñador no parece del todo favorable respecto al tejido general del drama, que se revelaría poco orgánico, sobre todo en el caso de algunos personajes. Se transcribe oportunamente un amplio párrafo:

«La rappresentazione di Elettra, data per la prima volta in Italia, con molta cura, dalla compagnia Mauri nella buona traduzione del Tedeschi, ci ha fatto comprendere quanta parte del successo doveva attribuirsi alla passione politica. Non che il dramma sia addirittura opera volgare, costruita con opportuni sermoni patriottici per strappare l'applauso della folla già eccitata. Non avrebbe potuto piegarsi a questo il Galdòs [sic], che non è il primo venuto e che, col Valera e col Pereda, è giudicato uno dei migliori moderni romanzieri spagnuoli. D'altra parte questa lotta contro il fanatismo e la superstizione è stata sempre l'essenza della sua arte. Già coi suoi lodatissimi Episodi nazionali e col romanzo Gloria, che è stimato il suo capolavoro, egli aveva da tempo spezzata vittoriosamente la lancia a vantaggio delle idee di progresso e di rinnovamento, ed anche in tutti gli altri suoi lavori il contrasto contro i secolari retrogradi della sua patria si mantiene stridente e vivo. E lo spettatore avverte subito che non ha innanzi un raro artista di parole, ma l'artista convinto, che combatte ardito per la sua idea. Merito questo reale e alto, che convince e affascina il pubblico non appena, come nelle scene del terzo atto, il drammaturgo trova il modo di affermarsi. Ma appunto questa affermazione continuata e organica, a me pare manchi assolutamente in Elettra. Se l'agile mano del romanziere si manifesta nel delineare con cura e nel rendere vero ed evidente il carattere da Tartufo di don Salvador Pantoja, non riesce ugualmente abile nel disegnare gli altri personaggi, che sono tutti, compresa Elettra, fantocci costruiti a misura secondo l'ordinazione dell'autore, e non si rivela poi nella tessitura del dramma, nel complesso, ingenuo e povero d'invenzione» (Grande 1901: 34).

\section{VENTENNIO FASCISTA (LA ÉPOCA FASCISTA)}

En la Italia de la dictadura fascista, la relación entre editoriales y sistema político fue compleja e ineludible (Polizzi 2008). Por un lado, se presenta el caso de las editoriales nacidas a finales del siglo anterior, en un ambiente cultural y político distinto —el de la recién Unificazione d'Italia de 1861-, y, por lo tanto, animados por un proyecto de construcción identitaria común, tanto social, como lingüística, que pasaría también por las traducciones al italiano de los clásicos y de las obras contemporáneas de las literaturas extranjeras. Alguna de estas editoriales, como la Bemporad que ya hemos presentado, 
sufrieron la discriminación antisemita, e, incluso antes de la emanación de las Leyes raciales, todas se enfrentaron con una forma u otra de sujeción al poder hegemónico a través de la imposición, para todos los institutos escolares, del Libro unico di Stato, en 1928. El Gobierno escogía anualmente a qué editorial encargar la publicación, determinando, de esta forma, la supervivencia de algunas o el mayor poder económico de otras. Por otro lado, fueron determinantes las subvenciones por parte del Régimen no solo para la creación de las nuevas editoriales, sino también para las ya aceptadas, como Mondadori desde 1907. Lo que el Régimen les pedía a todas las editoriales, así como a la prensa, era participar, de manera relevante, en el proyecto fascista de «instrucción masiva» que buscaba el acercamiento a todo un nuevo tipo de lectores, el popular, dentro del gran proyecto intelectual de acercar la literatura a las masas. Se trataba de favorecer la alfabetización de amplias clases sociales, dentro de una puntual política lingüística aún más unificadora, a través de la divulgación de los ya mencionados textos clásicos de la tradición literaria italiana, así como de la extranjera, pero volviendo, sin embargo, a escribirlos en un estilo y en una lengua más asequibles a dicho lector popular (Turi 1990; Albonetti 1994; Ragone 1999; Galfrè 2005; Billiani 2004; Mancini 2006; Cembali 2006; Tranfaglia-Vittoria 2007) e incluso alterando textos canónicos de las «otras» tradiciones literarias (Rundle 1999; 2000).

Por lo tanto, también la actividad editorial de la traducción se presenta, en un primer momento, como un proyecto de interés comercial. Y, de hecho, al principio, el Gobierno mussoliniano no introdujo en Italia ninguna medida de censura específica. Sin embargo, ya en 1934, al hacerse patente el peligro de «contaminación»-dentro del programa de control típico de los procesos culturales autoritarios- se obliga a las editoriales a entregar a la Prefettura tres copias de cada libro impreso, para que una comisión específica decidiera acerca de su comercialización con su nibil obstat. Por ejemplo, Pavese escribe lo siguiente en una carta a Luigi Rusca de la editorial Mondadori, fechada el 2 de junio de 1937, acerca de la traducción de la novela Big Money, de John R. Dos Passos, en la que estaba trabajando:

«Ho seguito scrupolosamente i consigli del Ministero cioè inglesizzato i nomi italiani, lasciato cadere gli accenni a Lenin e ai sovietici, cancellato e sostituito un accenno al fascismo, taciuto e tradotto con dignità wop e dago (...) come non segnalato dal Ministero nel dattiloscritto che serbo gelosamente a mia eventuale giustificazione» (Pavese 1968: 348). ${ }^{11}$

Posteriormente, en 1938, se produjo una eliminación gradual respecto a las traducciones, llegando a la imposición de una cuota oficial durante la Segunda Guerra Mundial. Todas los protagonistas del proceso editorial, entre ellos los traductores, se vieron obligados a pensar y actuar como el censor quería, intentando anticiparse a las posibles críticas y llegando a la paradoja intelectual de la «autocensura». La autocensura actuó como un sistema de revisión continuada por parte de las editoriales, implicando minuciosamente a cada figura del sistema de publicación, desde los autores y los traductores hasta los editores, los cuales fueron convirtiéndose en el censor principal de su misma actividad editorial. Todo ello se correspondía con una compleja praxis burocrática que

11 La cursiva está en el texto. 
hoy se conserva en los archivos de algunas editoriales, así como en el Archivio Centrale dello Stato del Minculpop (Ministero della Cultura popolare) en Roma. Se trataba de los célebres Pareri di lettura o Note di servizio. Los primeros eran fichas di lettura de las obras «con juicios críticos favorables o negativos redactados por los colaboradores internos o externos de las editoriales, los cuales, brevemente, subrayaban el valor literario del texto, además de la posibilidad de comercializarlo, y, finalmente proponían correcciones o, en algunos casos, reescrituras» (Polizzi 2005: 201-202). Las Note eran indicaciones que la censura oficial enviaba a las editoriales acerca de lo que se tenía que evitar y que a menudo estaba relacionado con la ética promovida por el Régimen y, en general, con la política lingüística nacional.

Dentro de este sistema editorial y de construcción del consenso por parte de la cultura hegemónica autoritaria, se vuelven a publicar en traducción italiana tres obras de Galdós, Marianela, Misericordia y Nazarín, y aparecen por primera vez tres más: Fortunata y Jacinta, El abuelo y Gerona.

En el periódico de Milán Pro Familia. Rivista Settimanale Illustrata aparece en 1925 una nueva versión de Marianela con el título Gli occhi che uccidono, relacionado más bien con el capítulo 21 de la novela, «Los ojos matan».

Fortunata e Giacinta. Storia di due donne maritate, "Prima versione italiana di Silvia Baccani Giani», se publica en Florencia en 1926, por la editorial Adriano Salani y en la colección Biblioteca Salani Illustrata. ${ }^{12}$ Un año antes, la misma traductora firmaba la edición italiana de Los pazos de Ulloa (Il castello di Ulloa), de Emilia Pardo Bazán, para la misma editorial, la cual seguirá publicando en los años siguientes otras novelas traducidas de la escritora gallega. Adriano Salani había fundado su editorial en 1862, con un carácter muy popular, publicando canciones, cuentos en rima y pliegos sueltos. Pronto ocupó un lugar destacado dentro de las publicaciones de literatura juvenil y de entretenimiento. Con la colección Biblioteca Salani Illustrata, empezó a exportar sus libros, sobre todo a Hispanoamérica, entre los emigrados italianos, con gran éxito también comercial. Emanuele Maucci fue su distribuidor quien en 1892 ya habia fundado su propia editorial en Barcelona, que, por ejemplo, publicó las traducciones de los exitosos Romanzi d'appendice de Carolina Invernizzi, editados en Italia por Salani. En 1904 la dirección de la editorial florentina pasa al hijo Ettore, que de empresa artesanal la convierte en industrial, hasta 1937, cuando, después de su muerte, le sucede su hijo Mario. Siguen años muy difíciles, con el cierre de la tipografía y la adquisición de la editorial por Mirko Skofiç, marido de Gina Lollobrigida. Entre las obras publicadas en este período, se recuerda la Divina Commedia con ilustraciones de Salvador Dalí. Las inundaciones de Florencia en 1966 marca el definitivo declive de la histórica editorial. En 1985, pasa al grupo Longanesi, que la traslada a Milán y la convierte en la editorial de las novelas de Harry Potter.

Acerca de Silvia Baccani Giani, probablemente de origen toscano y palermitana de adopción, los datos recogidos comprenden cierta actividad de ensayista, escritora y traductora. Participó en el ambiente cultural de la época entrando también en el cenáculo

12 El volumen es hoy día de difícil consulta, ya que una única copia localizada se encuentra entre las «Opere alluvionate» de la Biblioteca Nazionale di Firenze desde el aluvión de 1966 que padeció la ciudad toscana. 
romano del ecléctico intelectual Angelo De Gubernatis, ${ }^{13}$ el cual, por ejemplo, la cita en su libro L'Argentina. Ricordi e letture: «Molto desideroso di visitare il Chili, di cui una nostra gentile scrittrice che da sei anni vi dimora, la signora Silvia Baccani Giani, co' suoi racconti, mi aveva più fortemente invogliato, (...)» (1898: 138-139) (Benedetti 2014). De la estancia chilena de Baccani Giani, que será la ocasión para aprender el castellano y que —a partir de los datos que se han ido recogiendo y cotejando - tuvo que trascurrir en Santiago de Chile y extenderse desde 1884 hasta 1896, tenemos noticias primero en un carta que escribe en el puerto de Génova a punto de embarcarse para el país hispanoamericano con su marido (Maresta 2016), probablemente con la intención de emigrar, habiendo aceptado las ayudas económicas que ofrecía Chile, a finales del siglo XIX, para fomentar la inmigración desde Europa («Il Governo Chileno [sic] ci presta semplicemente il denaro del viaggio visto che qua non abbiamo né posto né lavoro, persuaso che in casa sua sapremo trovarcene. Ci tratta da amici e dobbiamo essergli riconoscenti», Maresta 2016). ${ }^{14}$ Más

13 Estableció una profunda relación con Angelo De Gubernatis, atestiguada por las 77 cartas fechadas entre 1895 y 1910 que le envió y que se guardan en el «Carteggio riservato» que el estudioso donó a la Biblioteca Nazionale Centrale di Firenze entre 1904 y 1907 con la nota coercitiva «da aprirsi soltanto cinquanta anni dopo la mia morte» ${ }^{13}$ (Masini 2007). Véase:

https://www.bncf.firenze.sbn.it/informazioni/testi/Carteggilnventari Cataloghi.

htm\#gubernatis, así como la ficha específica que se refiere al intercambio «Silvia Baccani Giani»: http://cataloghistorici.bdi.sbn.it/file_viewer.php?IDIMG=4766\&IDCAT =10\&

IDGRP $=100004 \&$ LEVEL $=\&$ PRT

14 La carta muestra el estilo narrativo-literario de la autora, además de cierto nivel cultural que la diferencia de la masa de los demás migrantes, haciéndola una especial observadora y narradora. Se transcribe un pasaje significativo: "Povera $\mathrm{g}(\mathrm{ente})$, la loro assoluta ignoranza li rende così poveri di spirito, così abbattuti e dubbiosi che camminano come ciechi, pronti ad allarmarsi per un ostacolo da nulla. Mentre mio marito attendeva il suo turno presso lo sportello dei biglietti in un lungo e stretto corridoio, io ero andata a sedermi in una sala dove qualche giovanotto attendeva discutendo. Io, che non ho aspettato agli ultimi momenti a leggere i fogli della Casa Gondrand, conoscevo un paragrafo che dice: "Il Governo Chileno non assicura il lavoro agli operai ecc. Uno degli emigranti, invece - come, del resto, quasi tutti - non lo aveva letto. A un tratto diventa pallido di collera, dà in esclamazioni disperate. "Sentite, sentite! È un tradimento! Ci fanno andar là a morir di fame! Bisogna protestare, farci rendere il nostro danaro, ecc. ecc. Poi si precipita verso il corridoio e a quanti entravano: "Avete firmato voi? No? Dunque fermi; non si firma nessuno. Si va tutti a protestare. Dove? Dall'impiegati è inutile. Dai Gondrand, sì. Dove sono? Mettiamoci d'accordo. Quanti siamo? A me tutto quell'allarme faceva compassione. Tutta quella gente in preda a un panico straziante mi commoveva. Senza muovermi dal posto dove me ne stavo seduta, mi volsi a uno che mi era vicino e ascoltava fremendo senza parlare. Quel giovanotto, gli dissi, fa del male a tutti. Mette lo scompiglio quando la calma è più necessaria. - Ma ha ragione però. - No, ha torto, non dà il giusto valore alla parola. Il Governo Chileno non può assicurare il lavoro perché non tiene schiavi i suoi capifabbrica e padroni di negozio e non gli obbliga a stipendiare operai di sua scelta, quando questi operai non gli conosce nemmeno e non può rispondere di loro. Il Governo Chileno ci presta semplicemente il denaro del viaggio visto che qua non abbiamo né posto né lavoro, persuaso che in casa sua sapremo trovarcene. Ci tratta da amici e dobbiamo essergli riconoscenti. (...). Mio marito torna qui dopo avere consegnato i bauli a bordo. Mi racconta mille cose dell'inconvenienti che incontrano quei poveri emigranti che vanno con la testa nel sacco» (Maresta 2016). Lo subrayado está en el texto. En el Catálogo «Fotografía Patrimonial» del Museo Histórico Nacional de Santiago de Chile (N. de inventario FA-229), se guarda una foto de Silvia Baccani Giani, sacada durante su estancia chilena, con la indicación «Retrato de poetisa italiana». Véase: http://www.fotografiapatrimonial.cl/p/14457. De los escasos datos acerca de su producción, en cuanto ensayista, aparece su estudio "Il Valdiviano: Studio sui costumi nazionali cileni di Arturo Girovich» en la Gazzetta ufficiale del Regno d'Italia, de 1896; en cuanto poeta, en la 
adelante, también tenemos muestra de ello en una de las cartas que componen el conjunto de cuatro misivas cuyo remitente es Silvia Baccani Giani dirigidas a Galdós y que forman parte del epistolario galdosiano. Estas cartas, junto a una posterior de Angelo De Gubernatis, serán muy interesantes, no solo para estudiar la génesis de la edición italiana de Fortunata y Jacinta, sino también para entender la larga demora antes de su publicación en 1926. En la primera carta, fechada como las demás en Palermo -ciudad de adopción de Baccani al volver de Chile- el 19 de junio de 1903, Baccani Giani escribe sobre su experiencia chilena y recuerda también la ocasión que le propició la posibilidad de conocer la novela galdosiana precisamente en el despacho romano del célebre profesor de literatura italiana De Gubernatis:

"Desidererei sapere se il suo romanzo "Fortunata e Jacinta" è mai stato tradotto all'italiano. Non le nascondo che ambisco l'onore di tradurlo io e che questo appunto è il motivo della mia domanda. Non avevo mai avuto, in passato, l'occasione di conoscere, se non che di fama, la S.V. chiarissima, non avendo mai pensato a studiare l'idioma spagnolo, molto trascurato - ed a torto - in Italia; ma dodici anni trascorsi da me nel Chili me lo resero necessario e quindi familiare. Devo dunque anch'io all'America la mia fortuna, cioè quella di aver potuto gustare le pagine di Pérez Galdós. Fu al mio ritorno, e proprio nell'alma Roma, che scopersi nel ricco studio del mio illustre amico conte Angelo De Gubernatis, il libro intitolato "Fortunata y Jacinta". Quei quattro volumi non li lessi già, ma li divorai (...)»

(Baccani Giani 19. 06.1903)

También en la carta de De Gubernatis (28.05.1910) se hace referencia a «una nobile scrittrice italiana, la signora Silvia Baccani Giani, che —en las palabras del intelectualho conosciuto, ed apprezzato, or sono quattordici anni a Santiago de Chile». Siguen dos tarjetas poco después $(15.07 .1903 ; 12.10 .1903)$, en la primera de las cuales la remitente solicita una respuesta por parte de Galdós, excusándose por haber enviado la carta a la dirección de la «Academia Espańola de Madrid»; la segunda, ya dirigida al conocido domicilio madrileño del escritor canario - C/ Hortaleza, 132- revela un intercambio epistolar ya bastante consolidado. La cuarta misiva que guardamos sigue fechada en Palermo, aunque seis años más tarde, 20 de noviembre de 1909, y apunta precisamente a la «longitud» de Fortunata y Jacinta como razón por la cual todavía la traductora no había encontrado una editorial italiana dispuesta a publicarla. ${ }^{15}$ Además, presenta nuevos proyectos de traducción, como un capítulo ya en italiano de La familia de León Roch que le envía aparte y, sobre todo, el texto completo de Gloria:

misiva a Galdós fechada el 12 de octubre de 1903 habla precisamente de dos sonetos manuscritos y finalmente, un testigo más de su actividad de traductora está constituido por la traducción del himno nacional chileno recopilado en Canales y Toro (1960: 47-49).

15 Hay que recordar que la primera edición de Fortunata y Jacinta. Dos historias de casadas, publicada por la editorial de Madrid La Guirnalda en 1887, se presenta con una notable extensión y se publicó en cuatro partes, cada una de las cuales constituía un tomo. La segunda edición, en dos tomos, salió treinta años más tarde, entre 1915 y 1918, en la editorial Sucesores de Hernando, muy probablemente debido al considerable cometido económico que suponía para cualquier editorial. 


\begin{abstract}
"Quando, diversi anni or sono, mi permise Ella di tradurre all'italiano il suo "Fortunata y Jacinta" (se avessi trovato un editore che non lo trovasse troppo lungo) non mi sgomentai per questa difficoltà e non abbandonai l'idea di tradurre o prima o poi qualche libro suo. Con questo fermo proposito, nel tempo che mi resta libero, vado leggendo quei libri suoi che posso avere e, fra i pochi che ho letto, mi ha specialmente incantato "La familia de León Roch" e, ultimamente, "Gloria". Di León Roch ho tradotto un capitolo che, a parte certificado, le invio, sperando di non averlo sciupato, ossia echado a perder. Lo scopo mio, con questi brevi saggi, è di invogliare gli editori Treves di Milano a pubblicare un libro completo, e questo vorrei che fosse "Gloria". I fratelli Treves sono judios e il libro suddetto dovrà essere di loro pieno gusto. Che ne dice Lei? Mi autorizza ad imprenderne la traduzione?» ${ }^{16}$ (Baccani Giani 20.11.1909).
\end{abstract}

En los catálogos consultados no se han encontrado huellas de las ediciones italianas de estas dos novelas, mientras que Fortunata e Giacinta tendrá que esperar muchos años todavía, hasta 1926, a un editor como Adriano Salani con relaciones comerciales con Espańa e Hispanoamérica y a una época diferente, marcada por un sistema cultural hegemónico autoritario. Un análisis traductológico entre los dos textos, el de partida y el de llegada, demuestra la reducción de la sustancia textual aproximadamente a una tercera parte respecto al original español (Polizzi 2007; 2008). En la edición italiana de la obra maestra de Galdós, las omisiones, las elisiones, las síntesis parafraseadas y las manipulaciones practicadas se pueden poner en relación con las normas culturales de la época, con los filtros ideológicos o los condicionamientos económicos, sociales e históricos, patentes o incluso inconscientes, en el traductor y en el editor. De hecho, además de proceder, en primera instancia, de la necesidad editorial de reducir el cuerpo del texto, a nivel estructural lo van «aligerando» — a menudo de forma somera — ya sea con peculiares recursos narrativos, como los adscribibles a la emisión de la voz narrante, ya sea con materia narrada de mayor carga de alusiones históricas o políticas. En el primer caso, se producen llamativas alteraciones estilísticas cuando la traductora se ve obligada a acudir a síntesis o introducción de datos para rellenar los vacíos en el entramado del argumento provocados por los pasajes eliminados. En el segundo caso, a modo de ejemplo, sobresale la completa supresión del capítulo II de la parte primera, «Santa Cruz y Arnaiz. Vistazo histórico sobre el comercio matritense» (1887), juzgado, con mucha probabilidad, como demasiado descriptivo para el gusto literario de la época de la publicación de la obra en Italia.

Para seguir con el panorama de las traducciones de la obra galdosiana de la Italia de este mismo periodo, en 1929 vuelve a editarse una nueva versión de Misericordia, firmada por el hispanista piamontés Camillo Berra, con un subtítulo de clara referencia costumbrista Misericordia. Scene di vita madrilena, por la editorial de Turín Cosmopolita, que la incluye en la colección I Grandi Scrittori Stranieri, fundada por el ilustre crítico literario Arturo Farinelli. En 1933, la adaptación teatral de El abuelo. Drama en cinco actos y en prosa (1904) se publica en versión italiana en Florencia por la editorial Nemi, dentro de la colección Teatro Comico e Drammatico, que dirigía el médico y dramaturgo Cipriano

16 Lo subrayado está en el texto. 
Giachetti, con el título Il nonno. Commedia drammatica y a cargo del traductor profesional Gilberto Beccari. Según recuerda Briganti (2014a; 2014b), los tres ańos pasados en Argentina, desde 1898-1901, así como en el caso de Silvia Baccani Giani, le dieron la posibilidad de aprender el español de tal forma que, al volver a Italia, parece dedicarse totalmente a la profesión, hasta convertirse en el traductor especialista de Miguel de Unamuno, con el cual tuvo incluso un interesante intercambio epistolar.

En los ańos cuarenta, una nueva versión de Marianela (Marianella) lleva la firma de Enzo Gemignani, célebre sobre todo como autor de novelas negras y traductor del francés, inglés, ruso y español. Se producen dos ediciones de la misma traducción de la novela en Italia, la de 1940 por la editorial Sonzogno de Milán y la de 1943, de la florentina Nerbini. Al año siguiente, en 1944, aparece la primera traducción de un episodio nacional, Gerona (1871), en la colección Grandi Ritorni de la editorial Bompiani de Milán, a cargo del hispanista Antonio Radames Ferrarín, muy presente en la prensa cultural italiana de la época con sus estudios y reseñas sobre numerosos autores españoles e hispanoamericanos, además de ser autor de manuales de lengua y de literatura españolas. En el volumen editado por el insigne hispanista y crítico literario Carlo Bo, Narratori spagnoli: Raccolta di romanzi e racconti, publicado en Milán por la misma editorial Bompiani en 1944, se incluye Affanni e contrattempi di un redentore, traducción de la novela $\mathrm{Na}$ zarín, por Carlo Boselli, cuya actividad de hispanista nace a raíz de su larga estancia en Espańa como delegado de la Pirelli; cuando regresa de España se dedica a la profesión de profesor de español y de traductor. Finalmente, la editorial de Turín Edizioni Palatine vuelve a editar la traducción de Camillo Berra de Misericordia (Misericordia. Romanzo) en 1945.

\section{LAS DÉCADAS DE LOS 50 A LOS 90}

A partir de la segunda posguerra europea, durante el llamado boom económico italiano y hasta los años noventa, cuando todavía seguían vigentes los derechos de propiedad intelectual del escritor canario, la obra traducida de Galdós aparece en los catálogos editoriales, aunque, una vez más, con la reiteración de ediciones de las mismas novelas galdosianas y muy contadas novedades. La más llamativa es, sin duda, la que se refiere a la primera aparición en versión italiana de Tristana (1892), en el mismo año de la adaptación cinematográfica de Luis Buńuel, en 1970, y su presentación en el XXIII Festival de Cannes. A partir de ese momento, han sido muchos los estudios que han profundizado en el tema de la relación entre la escritura de Galdós y la narración cinematográfica de Bunuel, por lo menos teniendo en consideración las tres obras que entrelazan directamente a los dos autores: Tristana, Narazin y Halma, esta última libremente adaptada en la película Viridiana (1961) (Galeota 1988; Bikandi 1997; Aguirre Carballeira 2006a, 2006b, 2009). Respecto a la recepción italiana a través de las traducciones, se podría hablar de un verdadero «fenómeno editorial» que, a partir del gran interés provocado por la relectura de la novela galdosiana en clave surrealista por parte del cineasta, no solo empujará a varias editoriales italianas a volver a publicar la traducción de Italo Argenti, sino que en la década de los noventa y también en años posteriores se editarán nuevas traducciones de la misma novela, según veremos de forma más detallada más adelante. Con mucha probabilidad, el mismo efecto lo produce el Nazarín de Buńuel de 1959, que 
gana el Premio Internacional en Cannes el mismo año, y vuelve a publicarse en Italia en la traducción de Carlo Boselli. Asimismo, mientras en los sesenta se reedita Trafalgar, en las décadas siguientes es Misericordia la que vuelve a interesar con diferentes traducciones. Las novedades se centran en las primeras traducciones de La sombra (1870), La de Bringas (1884), La loca de la casa (1892) y la narración odepórica Viaje a Italia (1888).

En la década de los cincuenta vuelve a aparecer Misericordia, primero la versión de Camillo Berra en 1954 en Turín por la editorial UTET (Unione Tipografica Editrice Torinese) y dos años más tarde, en 1956, en Milán, donde Rizzoli encarga la traducción a Antonio Gasparetti. De origen ligurio, fue hispanista y profesor de lengua y literatura españolas en institutos de bachillerato en Sicilia, así como en las Universidades de Palermo y de Milán; en Salamanca y en Barcelona dirigió durante unos años el Instituto Italiano de Cultura (Belloni, Crippa 2018). Su traducción de esta novela galdosiana volverá a aparecer en 1971 por la editorial Vallecchi de Florencia. Anteriormente, en 1965 y luego en 1982, la editorial UTET había reeditado la Misericordia de Berra con introducción de Paolo Pignata y en la colección Narrativa Spagnola. La editorial TEA de Milán también la publica con la misma introducción en 1991, probando un constante interés editorial por la novela de Galdós. De hecho, una nueva traducción, la del insigne hispanista Gabriele Morelli, aparece en 1970 en la editorial Fabbri de Milán en la colección Invito ai Classici, volviendo a editarse por la misma editorial en 1985, en 1991 y 1994. Finalmente, también Garzanti propone, en 1991, su versión de Misericordia a cargo de David Urman.

Trafalgar va a conocer el éxito en los años sesenta; de hecho, después de la primera traducción que Treves había publicado junto a Marianela, en 1961 el hispanista Ignazio Delogu firma su versión que publica Editori Riuniti de Roma; seguirán las ediciones de 1962 y 1966 en la sede de Bari de Edizioni Paoline y en 1967 otro gran hispanista, Vincenzo Josia, vuelve a traducir el primer episodio nacional galdosiano para la editorial Gremese de Roma.

En la misma década de los sesenta, Antonio Gasparetti publica su segunda traducción de obras galdosianas: se trata de La loca de la casa. Comedia en cuatro actos y en prosa (1892), la cual aparece en 1967 con el título La matta di casa: commedia in quattro atti en Catania, Edizioni Paoline, con la nota de su representación madrileña. ${ }^{17}$

Mientras tanto, en 1959, Luis Buñuel había adaptado al cine Nazarín, ganando el Premio Internacional en el Festival de Cannes y dando pie a una serie de conexiones entre su obra y la de Galdós. El eco fue tan relevante que podría explicar las reediciones en Italia de la traducción de Carlo Boselli, Affanni e contrattempi di un redentore, primero en 1966 por la editorial Sadea de Florencia y en la colección Romanzi e Racconti, y diez años más tarde, en 1977, por Mondadori. También hay que tener en cuenta, en el caso de esta última, el «efecto boomerang» a raíz del éxito de la segunda película en la que Buñuel adapta una novela de Galdós, Tristana, en 1970, que produce una reiteración de ediciones de su traducción italiana a partir del mismo año. La primera es la que corre a cargo de Italo Alighiero Chiusano, con prefacio de Angela Bianchini (ambos, escritores y traductores) por la editorial Adelphi de Milán (1970) y lleva en la faja precisamente la imagen de una escena de la película con Catherine Deneuve y Franco Nero.

17 «Rappresentata per la prima volta a Madrid, nel Teatro della Commedia, il 16 gennaio $1893 »$. 
La interpolación de Buñuel —opina Francesco Guazzelli (2010)— produce tal superposición de sentido entre el texto de Galdós y la personal lectura de Buñuel, que la recepción de la novela ya no podrá prescindir de esta mutua influencia. ${ }^{18} \mathrm{La}$ misma traducción vuelve a salir el año siguiente, así como en 1991, en Einaudi, y en 1975 en Mondadori. Sin embargo, entre 1991 y 1992 se producen dos versiones más de la novela; de hecho, Augusto Guarino firma la que se publica en Venecia por la editorial Marsilio en la colección Dulcinea y con introducción de Vito Galeota; por otro lado, Irina Bajini será la traductora de la Tristana publicada por Garzanti en 1992.

Cerramos esta temporada con tres primeras ediciones traducidas. La de Bringas (1884) aparece más de cien años después de su publicación en España, en 1993, gracias a la editorial milanesa Frassinelli y a la traductora Elena Clementelli, y con el título Donna di denari. También esta vez, la hispanista y traductora Angela Bianchini firma el prefacio, donde apunta a ulteriores redes que se hilvanarían entre Galdós y Buñuel:

«La lezione del barocco, venendogli spontanea, crea effetti illusionistici, vertiginosi che, dalla sensibilità ottocentesca, sembrano portare direttamente nel nostro secolo. Sembrano portare alla lezione del surrealismo così come sarà poi interpretato da Buñuel che, da Galdós, appunto, attingerà molti soggetti e alcune scene famose. Tale, nel film Veridiana, la scena del pasto dei poveri che, nei suoi risvolti ironici e beffardi, si ispira direttamente alla Lavanda dei poveri e al pasto offerto dai Reali agli stessi poveri in Donna di denari» (Bianchini 1993: VII).

El escrito de adscripción odepórica Viaje a Italia (ciudades) (1888) aparece traducido también en 1993 en Nápoles por la editorial Alfredo Giunta y con la traducción a cargo de Vito Cardone. Finalmente, Augusto Guarino firma la primera traducción de La sombra (1870) y su L'ombra se publica en 1995 por Argo Edizioni de Lecce.

\section{EL SIGLO XXI}

El comienzo del nuevo milenio se abre con una importante novedad editorial respecto a la obra literaria de Benito Pérez Galdós, puesto que pasa a dominio público por haberse prescrito los derechos de autor, al haber pasado ochenta ańos desde su muerte. ${ }^{19}$

18 «Si pensi all'edizione francese di Tristana della prestigiosa Flammarion, la quale nel 1992 si vale per la sua copertina del fotogramma dell'episodio descritto, e che il lettore invano cercherebbe nel romanzo che ha di fronte. La scelta della Flammarion di fare appello alle immagini del film non è un caso unico. Anche l'edizione italiana della Marsilio e molte altre europee, che non sto qui ad elencare, si valgono genericamente di un fotogramma tratto dalla pellicola di Buńuel, a riprova del rapporto che si è venuto a instaurare tra il testo letterario di Galdós e la sua traduzione cinematografica. E non si tratta, si badi bene, di un semplice specchietto per le allodole di tipo commerciale volto alla promozione del film, ma piuttosto della presa d'atto, conscia o inconscia, che quella di Buńuel fu la prima vera lettura critica di Tristana» (Guazzelli 2010: s. p.).

19 «El vencimiento de los derechos de autor implica que las obras de estos autores pueden ser editadas, digitalizadas o comunicadas públicamente por cualquier ciudadano o empresa, respetando los derechos morales y cualquier otro derecho recogido por la Ley de Propiedad Intelectual. [...]. Las obras en dominio público son aquellas que están libres de los derechos de explotación, o patrimoniales, del autor conforme a la legislación vigente de Propiedad Intelectual. En el caso de España, los derechos de ex- 
El resultado será, en primera estancia, una extraordinaria revisión y divulgación del corpus literario galdosiano, en España e Hispanoamérica, a diferentes niveles — con variada tipología de ediciones, desde las más filológicas y escolares hasta las menos cuidadasy en formatos multimedia. La consecuencia en el ámbito de la traducción y recepción en el extranjero será relevante en Italia y estará marcada por un fenómeno peculiar: la aparición, finalmente, de nuevas y primeras traducciones de textos de Galdós publicadas, no obstante, por editoriales en cierto sentido «menores», respecto al sistema del monopolio de las grandes empresas editoriales italianas. Muchas de estas mantienen su hegemonía cultural —incluido el control del mercado de la prensa- desde comienzos de siglo XX y, sobre todo, a través del proceso de apoyo a cambio de financiación del Ventennio fascista. Por lo tanto, por un lado, se hace posible, por fin, eludir la perplejidad y el rechazo de esos grupos editoriales. Efectivamente, estos no consideran rentable publicar a un autor como Galdós que, junto a muchos otros del siglo XIX espańol, es un desconocido para el gran público italiano y sigue ausente en los manuales de los Licei italianos, los cuales, sin embargo, mantienen la presencia de los autores de las demás literaturas europeas. Las mismas editoriales prefieren, de hecho, aprovechar el boom literario español que se extiende desde los autores de la Transición hasta la actualidad. Por otro lado, y excepto en algún caso, Galdós vuelve a llamar la atención de los lectores italianos a menudo en ediciones cuidadas, aunque en espacios editoriales «limitados», a menudo provinciales y periféricos, con escasas redes de difusión y por obra del esfuerzo de los pocos hispanistas italianos que se dedican al estudio del siglo XIX y que lo siguen proponiendo en los programas curriculares y en los laboratorios de traducción de las universidades italianas. En todo caso, si las grandes editoriales presentan obras de Galdós, lo hacen casi siempre reeditando traducciones ya publicadas y, por lo tanto, sin invertir en nuevas lecturas traductoras que implicarían revisiones o adecuaciones culturales al nuevo público lector.

Fortunata e Jacinta, publicada en Urbino en 2000 por el mismo traductor Alfredo Rocco, abre el panorama de los años 2000. Sigue Tristana, consolidándose como obra ya presente en la memoria de los lectores italianos y de previsible apuesta comercial en forma de anejo de periódicos de difusión nacional. En efecto, en 2004 L’Espresso y Repubblica ofrecen la novela de Galdós en una nueva versión a cargo de Francesco Guazzelli y dentro del proyecto editorial, que acompańa semanalmente la salida del número del periódico, «I Grandi Romanzi dell'800». En el mismo año, y probablemente a raíz de esto, Fabbri vuelve a publicar la traducción de Italo Alighiero Chiusano; mientras que en 2006 Garzanti vuelve a editar la anterior de Irina Bajini.

También Trafalgar reaparece con nuevas versiones: la de 2008, firmada por Giuseppe Gentile, se publica en Roma por La Nuova Frontiera; la de 2013 sale en Aosta, en la edi-

plotación que disfruta el autor en vida subsisten setenta años después de su muerte, y se computan desde el día primero de enero del ańo siguiente al de la muerte o declaración de su fallechos de explotación que disfruta el autor en vida subsisten setenta años después de su muerte, y se computan desde el día primero de enero del año siguiente al de la muerte o declaración de su fallecimiento. No obstante, se respeta el plazo de 80 ańos para los autores cuya muerte tuvo lugar estando vigente la anterior ley de 10 de enero de 1879, es decir, hasta el 7 de diciembre de 1987. Una vez transcurrido el citado plazo, las obras pasan definitivamente a dominio público». Véase: http://www.bne.es/es/AreaPrensa/noticias2014/1015-autores-en-dominio-publico.html. 
torial Faligi, a cargo de Maddalena Morabito. En 2006, la profesora Maria Rosaria Alfani recopila y edita las traducciones de sus alumnos, fruto de la actividad docente, como ejemplo de cuanto se ha señalado, y aparece la primera versión de Tormento (1884), publicada en Cava dei Tirreni por la editorial Merlin, a cargo de Ugo Castaldi, Roberta Duccillo y Salvatore Vitale. Seguirá la primera traducción de El amigo Manso (1882), L'amico Manso, en 2010, firmada por Lucio Sessa para Mephite de Avellino; una primera traducción de L'incognita en 2011, de Laura Silvestri, que encuentra hueco en una editorial nacional en Rizzoli y que, sin embargo, en 2018, volverá a aparecer en otra editorial de más limitado alcance, como Theoria de Santarcangelo di Romagna. La profesora Laura Silvestri firma también una nueva versión de Marianela para Liguori de Nápoles en 2012, así como Fiorenzo Toso propone su Donna Perfecta en 2014, publicada en Savona por Pentàgora Edizioni. Un caso excepcional, por llamativo, lo representan las primeras ediciones traducidas de las novelas La desheredada (1881) y Realidad (1889). De hecho, las dos se publican en Madrid por la editorial fundada y dirigida por Rosa Amor del Olmo, Isidora Ediciones, la cual dedica, de forma extraordinaria, una parte de su proyecto editorial a las traducciones de la producción galdosiana a varios idiomas, entre los cuales el hebreo y el árabe. Por lo tanto, Realtà se publica en 2009 a cargo de Sagrario del Río, mientras que quien esto escribe firma La diseredata en $2011 .{ }^{20}$

Entretanto, empieza a aparecer en versión italiana la producción cuentística galdosiana. En 2006, Maria Rosaria Alfani también publica la colección Racconti fantastici en la editorial romana Donzelli, que reúne once cuentos muy representativos de tal modalidad narrativa, que, a menudo, en la escritura de Galdós, incluye elementos fantásticos y metanarrativos. ${ }^{21}$ Dos años más tarde, la editorial UTET incluye en su colección navideña Strenne, Natale spagnolo. Racconti, una colección de cuentos de Galdós, Pardo Bazán y Clarín con la traducción a cargo de Angelo Valastro Canale, más célebre por la primera edición bilingüe hispano-italiana de El Quijote (Bompiani, 2012). Siguiendo con el género del cuento, «Il racconto nel tram» («La novela en el tranvía», 1871) aparece en 2010 en formato tascabile (edición de bolsillo) por la editorial Cento Autori de Villarica y con la traducción de Tiziana Affinito; asimismo, en 2015, en otra colección, Il Molino a Vento e Altre Prose de la editorial Galaad de Giulianova, Riccardo Ferrazzi recopila textos traducidos de Galdós, Gabriel Miró y Vicente Blasco Ibáñez, entre los cuales se encuentran los galdosianos «Rompicapo» («Rompecabezas», 1887) y «L'articolo di fondo» («El artículo de fondo», 1889).

Se guarda un espacio editorial también para los episodios de Galdós todavía olvidados en Italia: Eleonora Demarzo publica, en 2014 y 2015, respectivamente, Cadice. Novella y L'equipaggio del re José. Novella en Tropea, editorial Meligrana, mientras que Antonio Boccardo y Diego Simini firman Amedeo I para Pensa Multimediale de Rovato, en 2015.

20 Me es muy grata la oportunidad de volver a expresar mi profundo agradecimiento a Rosa Amor por la excepcional experiencia que me ha ofrecido y, sobre todo, por su amistad.

21 Se trata de los siguientes cuentos que se citan con el título traducido y con el nombre del traductor: Ugo Castaldi, «Un'industria che vive della morte: episodio musicale del colera», "La congiura delle parole»; Domenico D’Amiano, «La piuma e il vento», «La principessa e il monello», «Rompicapo»; Salvatore Vitale, «Il bue e l'asinello», «Theros», «Tropiquillos»; Roberta Duccillo, «Celín», «Dov’è la mia testa», «Il portico della gloria». 
Seguirán las ediciones de Bailén (1873) y Un faccioso más y algunos frailes menos (1879), con las traducciones a cargo de Antonietta Zazzara y de Michela Poletti, respectivamente, por la editorial Faligi y en EBook. De hecho, algunas editoriales y, sobre todo, la editorial Faligi publicarán nuevas traducciones de muchas obras de Galdós en formato electrónico, cuya información se da en la tabla que aparece en el apéndice.

En los escasos casos, como hemos visto, de traducciones de la producción teatral galdosiana, en 2010 aparece la versión italiana a cargo de Trinis Maria Antonietta Fajardo de Alceste, por la editorial Nuova Cultura de Roma. Finalmente, cabe mencionar, en ocasión del centenario de la muerte de Benito Pérez Galdós, que está en prensa la recopilación de escritos galdosianos en traducción inédita Memorie di uno smemorato ed altri scritti, en la colección TransLitterae de UniPaPress (Servicio de Publicaciones de la Universidad de Palermo). ${ }^{22}$

\section{Conclusión}

A modo de conclusión, se ha intentado reflexionar sobre los datos editoriales acerca de la recepción italiana de la producción de Benito Pérez Galdós a través de las traducciones. Se ha ofrecido, por lo tanto, un panorama que, desde la época contemporánea al escritor canario hasta la actualidad, se presenta heterogéneo y, sin embargo, se trata de un reflejo de aquellos factores sociales, económicos y hasta ideológicos que siguen interviniendo en cualquier proceso de recepción de productos culturales y en relación simbiótica con la praxis de la traducción.

22 Se trata del resultado del trabajo de fin de máster en Traducción que he dirigido a raíz del curso de Traducción literaria (espańol-italiano) que imparto. 
APÉNDICE

\begin{tabular}{|c|c|c|c|c|}
\hline \multicolumn{5}{|c|}{ T A B L A } \\
\hline \multicolumn{5}{|c|}{ TRADUCCIONES DE LAS OBRAS DE GALDÓS PUBLICADAS EN ITALIA ${ }^{23}$} \\
\hline \multicolumn{5}{|c|}{ PERIODO CONTEMPORÁNEO A GALDÓS (1874-1907) } \\
\hline $\begin{array}{c}\text { Prototexto/ } \\
\text { (año publicación) }\end{array}$ & $\begin{array}{c}\text { Metatexto/ } \\
\text { (año publicación) }\end{array}$ & $\begin{array}{c}\text { Lugar/ } \\
\text { Editorial-Revista }\end{array}$ & Traductor & Notas \\
\hline $\begin{array}{l}\text { La fontana de oro } \\
\qquad(1870)\end{array}$ & $\begin{array}{l}\text { La fontana d'oro: } \\
\text { romanzo } \\
(1874) \\
\text { La fontana d'oro } \\
(1878) \\
\text { La fontana d'oro } \\
\text { (1879) } \\
\text { La fontana d'oro } \\
(1890)\end{array}$ & $\begin{array}{c}\text { Milano, Treves } \\
\text { Milano, } \\
\text { La Ragione } \\
\text { Napoli, Il Pungolo } \\
\text { Milano, Treves }\end{array}$ & $\begin{array}{c}\text { Federico Pozzani } \\
\text { Eugenio Fabris } \\
\text { Eugenio Fabris } \\
\text { Giacomo } \\
\text { Demichelis }\end{array}$ & \\
\hline $\begin{array}{c}\text { Doña Perfecta } \\
\quad(1876)\end{array}$ & $\begin{array}{c}\text { Donna Perfetta: } \\
\text { racconto } \\
(1897) \\
\text { Donna Perfetta } \\
(1892) \\
\text { La signora Perfetta } \\
(1894)\end{array}$ & $\begin{array}{l}\text { Milano, Treves } \\
\text { Milano, } \\
\text { La Perseveranza. } \\
\text { Giornale del } \\
\text { mattino } \\
\text { Bari, Corriere } \\
\text { delle Puglie }\end{array}$ & $\begin{array}{c}\text { (?) Rómulo Cúneo } \\
\text { y Vidal } \\
\text { Irma Rios } \\
\text { Diana D'Alteno }\end{array}$ & $\begin{array}{l}\text { Col. "Biblioteca } \\
\text { Amena" } 507 \\
\text { Pseudonimo de } \\
\text { G.C. Bernardi }\end{array}$ \\
\hline Gloria (1877) & $\begin{array}{c}\text { Gloria. } \\
\text { Romanzo } \\
\text { contemporaneo } \\
(1901)\end{array}$ & $\begin{array}{c}\text { Firenze, } \\
\text { Bemporad }\end{array}$ & Italo Argenti & $\begin{array}{c}\text { "Prima } \\
\text { traduzione } \\
\text { italiana dallo } \\
\text { spagnolo } \\
\text { autorizzata } \\
\text { dall'autore" }\end{array}$ \\
\hline $\begin{array}{c}\text { Marianela }(1878) \\
\text { Marianela, } \\
\text { Trafalgar } \\
(1878,1873)\end{array}$ & $\begin{array}{c}\text { Marianella }(1880) \\
\text { Marianela e } \\
\text { Trafalgar (1907) }\end{array}$ & $\begin{array}{c}\text { Bologna, } \\
\text { Tipografia } \\
\text { Pontificia } \\
\text { Mareggiani } \\
\text { Milano, Treves }\end{array}$ & $\begin{array}{l}\text { Giacomo } \\
\text { Demichelis }\end{array}$ & $\begin{array}{c}\text { Col. "Biblioteca } \\
\text { Amena" } 720\end{array}$ \\
\hline $\begin{array}{c}\text { La familia de } \\
\text { León Roch (1878) }\end{array}$ & $\begin{array}{l}\text { La famiglia di Leone } \\
\text { Roch (1883) }\end{array}$ & La Perseveranza & Daniele Rubbi & $\begin{array}{c}\text { (agosto- } \\
\text { noviembre) }\end{array}$ \\
\hline Nazarin (1895) & $\begin{array}{l}\text { Sicut Christus: } \\
\text { romanzo } \\
\text { contemporáneo } \\
(1902)\end{array}$ & Firenze, Nerbini & $\begin{array}{l}\text { Guido } \\
\text { Rubetti/ } \\
\text { José León } \\
\text { Pagano }\end{array}$ & $\begin{array}{l}\text { "Prima versione } \\
\text { autorizzata } \\
\text { dall'autore" - } \\
\text { Tip. Campolmi }\end{array}$ \\
\hline
\end{tabular}

23 En los diferentes apartados, se sigue el orden cronológico de publicación de los prototextos. 


\begin{tabular}{|c|c|c|c|c|}
\hline \multicolumn{5}{|c|}{ T A B L A (CONTINUACIÓN) } \\
\hline $\begin{array}{c}\text { Electra } \\
(30.01 .1901, \\
\text { Madrid, Teatro } \\
\text { Español) }\end{array}$ & Elettra $(27.04 .1901)$ & & $\begin{array}{l}\text { Enrique } \\
\text { Tedeschi }\end{array}$ & $\begin{array}{c}\text { Roma, Teatro } \\
\text { Manzoni, } \\
\text { Compañía } \\
\text { Mauri }\end{array}$ \\
\hline \multicolumn{5}{|c|}{ VENTENNIO FASCISTA (la época fascista): } \\
\hline $\begin{array}{c}\text { Prototexto/ } \\
\text { (año publicación) }\end{array}$ & $\begin{array}{c}\text { Metatextol } \\
\text { (año publicación) }\end{array}$ & $\begin{array}{c}\text { Lugarl } \\
\text { Editorial-Revista }\end{array}$ & Traductor & Notas \\
\hline Gerona (1871) & Gerona: 1874 (1944) & $\begin{array}{l}\text { Milano, } \\
\text { Bompiani }\end{array}$ & $\begin{array}{l}\text { Antonio } \\
\text { Radames } \\
\text { Ferrarin }\end{array}$ & $\begin{array}{l}\text { Col. "Grandi } \\
\text { Ritorni" }\end{array}$ \\
\hline Marianela (1878) & $\begin{array}{c}\text { Gli occhi che } \\
\text { uccidono (1925) } \\
\text { Marianella (1940) } \\
\text { Marianella (1943) }\end{array}$ & $\begin{array}{c}\text { Pro Familia. } \\
\text { Rivista } \\
\text { settimanale } \\
\text { illustrata } \\
\text { Milano, } \\
\text { Sonzogno } \\
\text { Firenze, Nerbini }\end{array}$ & $\begin{array}{l}\text { Enzo Gemignani } \\
\text { Enzo Gemignani }\end{array}$ & \\
\hline $\begin{array}{l}\text { Fortunata y } \\
\text { Jacinta. } \\
\text { Dos } \\
\text { historias de } \\
\text { casadas (1887) }\end{array}$ & $\begin{array}{l}\text { Fortunata e } \\
\text { Giacinta. } \\
\text { Storia di due donne } \\
\text { maritate (1926) }\end{array}$ & Firenze, Salani & $\begin{array}{l}\text { Silvia Baccani } \\
\text { Giani }\end{array}$ & $\begin{array}{l}\text { Col. "Biblioteca } \\
\text { Salani Illustrata" } \\
\text { _ "Prima ver- } \\
\text { sione italiana di } \\
\text { Silvia Baccani } \\
\text { Giani" }\end{array}$ \\
\hline Nazarin (1895) & $\begin{array}{c}\text { Affannie } \\
\text { contrattempi di } \\
\text { un redentore }(1944)\end{array}$ & $\begin{array}{l}\text { Milano, } \\
\text { Bompiani }\end{array}$ & Carlo Boselli & $\begin{array}{l}\text { En Carlo Bo } \\
\text { (ed.), Narratori } \\
\text { spagnoli. } \\
\text { Raccolta di } \\
\text { romanzi e } \\
\text { racconti }\end{array}$ \\
\hline $\begin{array}{l}\text { Misericordia } \\
(1897)\end{array}$ & $\begin{array}{c}\text { Misericordia. } \\
\text { Scene di vita } \\
\text { madrilena (1929) } \\
\text { Misericordia. } \\
\text { Romanzo (1945) }\end{array}$ & $\begin{array}{c}\text { Torino, } \\
\text { Cosmopolita } \\
\text { Torino, Edizioni } \\
\text { Palatine }\end{array}$ & $\begin{array}{l}\text { Camillo Berra } \\
\text { Camillo Berra }\end{array}$ & \\
\hline \multicolumn{5}{|c|}{ LAS DÉCADAS DE LOS 50 A LOS 90} \\
\hline La sombra (1870) & L'ombra (1995) & Lecce, Argo & Augusto Guarino & \\
\hline Trafalgar (1873) & $\begin{array}{l}\text { Trafalgar (1961) } \\
\text { Trafalgar (1962) } \\
\text { Trafalgar (1966) } \\
\text { Trafalgar (1967) }\end{array}$ & \begin{tabular}{|c|} 
Roma, \\
Editori Riuniti \\
Bari, \\
Ed. Paoline \\
Bari, \\
Ed. Paolini \\
Roma, Ed. Gremese
\end{tabular} & $\begin{array}{c}\text { Ignazio } \\
\text { DeloguVincenzo } \\
\text { Josia }\end{array}$ & \\
\hline
\end{tabular}




\begin{tabular}{|c|c|c|c|c|}
\hline \multicolumn{5}{|c|}{ T A B L A (CONTINUACIÓN) } \\
\hline $\begin{array}{c}\text { La de Bringas } \\
\text { (1884) }\end{array}$ & $\begin{array}{c}\text { La donna di } \\
\text { denari (1993) }\end{array}$ & $\begin{array}{l}\text { Milano, } \\
\text { Frassinelli }\end{array}$ & Elena Clementelli & $\begin{array}{c}\text { Prefacio Angela } \\
\text { Bianchini }\end{array}$ \\
\hline $\begin{array}{c}\text { Viaje a Italia } \\
\text { (las ciudades) } \\
\quad(1888)\end{array}$ & Città italiane (1993) & $\begin{array}{c}\text { Napoli, } \\
\text { Alfredo Guida }\end{array}$ & Vito Cardone & \\
\hline Tristana (1892) & $\begin{array}{l}\text { Tristana (1970) } \\
\text { Tristana }(1975) \\
\text { Tristana (1991) } \\
\text { Tristana (1991) } \\
\text { Tristana (1992) }\end{array}$ & $\begin{array}{c}\text { Milano, } \\
\text { Adelphi Milano, } \\
\text { Mondadori } \\
\text { Torino, } \\
\text { EinaudiVenezia, } \\
\text { Marsilio Milano, } \\
\text { Garzanti }\end{array}$ & $\begin{array}{c}\text { Italo Alighiero } \\
\text { ChiusanoItalo } \\
\text { Alighiero } \\
\text { Chiusano Italo } \\
\text { Alighiero } \\
\text { Chiusano } \\
\text { Augusto } \\
\text { Guarino } \\
\text { Irina Bajini }\end{array}$ & $\begin{array}{l}\text { Prefacio Angela } \\
\text { Bianchini } \\
\text { Prefacio Angela } \\
\text { Bianchini } \\
\text { Intro. } \\
\text { Vito Galeota, } \\
\text { Prefacio } \\
\text { "Dulcinea"Col. } \\
\text { "I Grandi Libri" }\end{array}$ \\
\hline $\begin{array}{l}\text { La loca de la casa. } \\
\text { Comedia en } \\
\text { cuatro actos y en } \\
\text { prosa (1893) }\end{array}$ & $\begin{array}{l}\text { La matta di casa: } \\
\text { commedia in } \\
\text { quattro atti (1967) }\end{array}$ & $\begin{array}{l}\text { Catania, } \\
\text { Ed. Paoline }\end{array}$ & $\begin{array}{l}\text { Antonio } \\
\text { Gasparetti }\end{array}$ & $\begin{array}{c}\text { "Rappresentata } \\
\text { per la prima } \\
\text { volta a Madrid, } \\
\text { nel Teatro della } \\
\text { Commedia, il } \\
16 \text { gennaio } \\
1893 "\end{array}$ \\
\hline Nazarín (1895) & $\begin{array}{c}\text { Affanni e } \\
\text { contrattempi di un } \\
\text { redentore (1966) } \\
\text { Affanni e } \\
\text { contrattempi di un } \\
\text { redentore (1977) }\end{array}$ & $\begin{array}{c}\text { Firenze, Sadea } \\
\text { Milano, } \\
\text { Mondadori }\end{array}$ & Carlo Boselli & $\begin{array}{l}\text { Col. "Romanzi } \\
\text { e Racconti" }\end{array}$ \\
\hline $\begin{array}{c}\text { Misericordia } \\
(1897)\end{array}$ & $\begin{array}{l}\text { Misericordia (1965) } \\
\text { Misericordia }(1970) \\
\text { Misericordia }(1971) \\
\text { Misericordia }(1982) \\
\text { Misericordia }(1985) \\
\text { Misericordia }(1991) \\
\text { Misericordia (1991) } \\
\text { Misericordia (1991) } \\
\text { Misericordia }(1994)\end{array}$ & $\begin{array}{c}\text { Torino, } \\
\text { UTET Milano, } \\
\text { Fabbri } \\
\text { Firenze, } \\
\text { Vallecchi } \\
\text { Torino, UTET- } \\
\text { Milano, Fabbri } \\
\text { Milano, Fabbri- } \\
\text { Milano, TEA } \\
\text { Milano, } \\
\text { Garzanti Milano, } \\
\text { Fabbri }\end{array}$ & $\begin{array}{c}\text { Camillo BerraGa- } \\
\text { briele MorelliAn- } \\
\text { tonio } \\
\text { GasparettiCamillo } \\
\text { BerraGabriele } \\
\text { MorelliGabriele } \\
\text { MorelliCamillo } \\
\text { BerraDavid Ur- } \\
\text { manGabriele Mo- } \\
\text { relli }\end{array}$ & $\begin{array}{l}\text { Intro. Paolo } \\
\text { Pignata. } \\
\text { Colec. } \\
\text { "Narrativa } \\
\text { spagnola" } \\
\text { Col. } \\
\text { "Invito ai } \\
\text { classici" } \\
\text { Intro. } \\
\text { Paolo Pignata- } \\
\text { Collana } \\
\text { "I Grandi Libri" }\end{array}$ \\
\hline
\end{tabular}




\begin{tabular}{|c|c|c|c|c|}
\hline \multicolumn{5}{|c|}{ T A B L A (CONTINUACIÓN) } \\
\hline \multicolumn{5}{|c|}{ SIGLO XXI } \\
\hline $\begin{array}{l}\text { La fontana de oro } \\
(1870)\end{array}$ & $\begin{array}{l}\text { La fontana d'oro } \\
\text { (2016) }\end{array}$ & Aosta, Faligi & Roberta Turino & EBook \\
\hline $\begin{array}{l}\text { Cuentos } \\
\text { (varias fechas) }\end{array}$ & $\begin{array}{c}\text { Racconti fantastici } \\
\text { (2006) } \\
\text { Natale spagnolo: } \\
\text { racconti } \\
\text { (Benito Pérez } \\
\text { Galdós, Emilia } \\
\text { Pardo Bazán, } \\
\text { Leopoldo Alas } \\
\text { Clarín) (2008) }\end{array}$ & $\begin{array}{l}\text { Roma, Donzelli- } \\
\text { Torino, UTET }\end{array}$ & $\begin{array}{c}\text { Ugo Castaldi, } \\
\text { Domenico } \\
\text { D’Amiano, } \\
\text { Roberta Duccillo, } \\
\text { Salvatore Vitale } \\
\text { Angelo Valastro } \\
\text { Canale }\end{array}$ & \\
\hline Trafalgar (1873) & $\begin{array}{l}\text { Trafalgar (2008) } \\
\text { Trafalgar (2010) } \\
\text { Trafalgar (2013) } \\
\text { Trafalgar (2016) }\end{array}$ & $\begin{array}{c}\text { Roma, La Nuova } \\
\text { Frontiera } \\
\text { Roma, La Nuova } \\
\text { Frontiera } \\
\text { Aosta, Faligi } \\
\text { Aosta, Faligi }\end{array}$ & $\begin{array}{l}\text { Giuseppe } \\
\text { Gentile } \\
\text { Giuseppe } \\
\text { Gentile } \\
\text { Maddalena } \\
\text { Morabito } \\
\text { Ilaria Di Loreto }\end{array}$ & $\begin{array}{l}\text { EBook } \\
\text { EBook }\end{array}$ \\
\hline $\begin{array}{l}\text { "La novela en el } \\
\text { tranvía" (1871) }\end{array}$ & $\begin{array}{l}\text { "Il romanzo nel } \\
\text { tram" (2010) }\end{array}$ & $\begin{array}{l}\text { Villaricca, } \\
\text { Cento autori }\end{array}$ & Tiziana Affinito & Ebook \\
\hline Bailén (1873) & Bailén (2016) & Aosta, Faligi & $\begin{array}{c}\text { Antonietta } \\
\text { Zazzara }\end{array}$ & EBook \\
\hline Cádiz (1874) & $\begin{array}{l}\text { Cadice: novella } \\
\qquad(2014)\end{array}$ & Tropea, Meligrana & $\begin{array}{l}\text { Eleonora } \\
\text { Demarzo }\end{array}$ & $\begin{array}{l}\text { Col. "Narrativa } \\
\text { inclusa" }\end{array}$ \\
\hline $\begin{array}{c}\text { El equipaje del rey } \\
\text { José }(1875)\end{array}$ & $\begin{array}{c}\text { L'equipaggio del re } \\
\text { José. Novella } \\
(2015)\end{array}$ & Tropea, Meligrana & $\begin{array}{l}\text { Eleonora } \\
\text { Demarzo }\end{array}$ & \\
\hline $\begin{array}{c}\text { Doña Perfecta } \\
(1876)\end{array}$ & $\begin{array}{c}\text { Donna Perfecta } \\
(2014)\end{array}$ & Savona, Pentágora & Fiorenzo Toso & \\
\hline Marianela (1878) & $\begin{array}{l}\text { Marianela (2011) } \\
\text { Marianella (2012) }\end{array}$ & $\begin{array}{l}\text { Aosta, FaligiNa- } \\
\text { poli, Liguori }\end{array}$ & $\begin{array}{c}\text { Emilia Di } \\
\text { Benedetto } \\
\text { Laura Silvestri }\end{array}$ & $\begin{array}{c}\text { EBook } \\
\text { También en } \\
\text { EBook }\end{array}$ \\
\hline $\begin{array}{l}\text { Un faccioso más y } \\
\text { algunos frailes } \\
\text { menos (1879) }\end{array}$ & $\begin{array}{c}\text { Un fazioso in più e } \\
\text { alcuni frati in meno } \\
\text { (2016) }\end{array}$ & Aosta, Faligi & Michela Poletti & EBook \\
\hline $\begin{array}{c}\text { La desheredada } \\
(1881)\end{array}$ & $\begin{array}{l}\text { La diseredata } \\
\text { (2011) }\end{array}$ & $\begin{array}{l}\text { Madrid, Isidora } \\
\text { ediciones }\end{array}$ & Assunta Polizzi & $\begin{array}{c}\text { Prefacio Germán } \\
\text { Gullón }\end{array}$ \\
\hline $\begin{array}{c}\text { El amigo Manso } \\
\text { (1882) }\end{array}$ & $\begin{array}{l}\text { L'amico Manso } \\
\qquad(2010)\end{array}$ & Avellino, Mephite & Lucio Sessa & $\begin{array}{c}\text { Col. "Benito Pérez } \\
\text { Galdós" }\end{array}$ \\
\hline
\end{tabular}




\begin{tabular}{|c|c|c|c|c|}
\hline \multicolumn{5}{|c|}{ T A B L A (CONTINUACIÓN) } \\
\hline Tormento (1884) & $\begin{array}{l}\text { Tormento }(2015) \\
\text { Tormento }(2006) \\
\text { Tormento }(2016)\end{array}$ & Aosta, Faligi & $\begin{array}{l}\text { Valentina } \\
\text { Chiarella }\end{array}$ & $\begin{array}{l}\text { EBook } \\
\text { Col. "I lapilli" } \\
\text { Introd. } \\
\text { Maria Rosaria } \\
\text { Alfani }\end{array}$ \\
\hline $\begin{array}{l}\text { Fortunata y Jacinta } \\
\qquad(1887)\end{array}$ & $\begin{array}{l}\text { Fortunata e Jacinta } \\
\qquad(2000)\end{array}$ & Urbino, Rocco & Alfredo Rocco & \\
\hline $\begin{array}{c}\text { "Rompecabezas" } \\
(1887), \\
\text { "El artículo de } \\
\text { fondo" (1898) }\end{array}$ & $\begin{array}{l}\text { "Il rompicapo", } \\
\text { "Larticolo di } \\
\text { fondo" (2015), } \\
\text { en Il molino a } \\
\text { vento e altre prose }\end{array}$ & $\begin{array}{c}\text { Giulianova, } \\
\text { Galaad Edizioni }\end{array}$ & $\begin{array}{l}\text { Riccardo Ferrazzi, } \\
\text { Marino Magliani }\end{array}$ & $\begin{array}{c}\text { Textos de Galdós, } \\
\text { Pardo Bazán y } \\
\text { Clarín }\end{array}$ \\
\hline Realidad (1889) & Realtà (2009) & $\begin{array}{l}\text { Madrid, Isidora } \\
\text { Ediciones }\end{array}$ & Sagrario del Río & \\
\hline $\begin{array}{l}\text { La incógnita } \\
\text { (1889) }\end{array}$ & $\begin{array}{c}\text { L'incognita } \\
\text { (2011)L'incognita } \\
\text { (2018) }\end{array}$ & $\begin{array}{l}\text { Milano, Ed. } \\
\text { Internazionali } \\
\text { Rizzoli } \\
\text { Santarcangelo di } \\
\text { Romagna, } \\
\text { Edizioni Theoria }\end{array}$ & $\begin{array}{l}\text { Laura Silvestri- } \\
\text { Laura Silvestri }\end{array}$ & Col. "Asce"EBook \\
\hline $\begin{array}{c}\text { Torquemada en la } \\
\text { hoguera (1889) }\end{array}$ & $\begin{array}{l}\text { Torquemada sul } \\
\text { rogo }(2016)\end{array}$ & Aosta, Faligi & Giulia Santangelo & EBook \\
\hline Tristana (1892) & $\begin{array}{l}\text { Tristana }(2004) \\
\text { Tristana }(2004) \\
\text { Tristana }(2004) \\
\text { Tristana }(2006) \\
\text { Tristana }(2015)\end{array}$ & $\begin{array}{c}\text { Roma, } \\
\text { L'Espresso } \\
\text { Roma, } \\
\text { La Repubblica } \\
\text { Milano, } \\
\text { Fabbri } \\
\text { Milano, } \\
\text { Garzanti } \\
\text { Catanzaro, } \\
\text { Montecovello }\end{array}$ & $\begin{array}{c}\text { Francesco } \\
\text { Guazzelli } \\
\text { Francesco } \\
\text { GuazzelliItalo } \\
\text { Alighiero } \\
\text { Chiusano } \\
\text { Irina Bajini } \\
\text { Manuela Arminio }\end{array}$ & $\begin{array}{l}\text { AnejoAnejo. Col. } \\
\text { "I Grandi Ro- } \\
\text { manzi dell'800" } \\
\text { Col. "I tesoro } \\
\text { della letteratura" } \\
\text { Col. "I Grandi } \\
\text { Libri" } \\
\text { EBook. } \\
\text { Ed. Francesco } \\
\text { Rizza }\end{array}$ \\
\hline $\begin{array}{c}\text { La loca de la casa } \\
\text { (1893) }\end{array}$ & $\begin{array}{l}\text { La pazza di casa } \\
\text { (2014) }\end{array}$ & Aosta, Faligi & $\begin{array}{l}\text { Ilaria Rita } \\
\text { Maisano }\end{array}$ & EBook \\
\hline $\begin{array}{l}\text { Misericordia } \\
(1897)\end{array}$ & $\begin{array}{l}\text { Misericordia } \\
\quad(2013)\end{array}$ & Aosta, Faligi & Elisa Merola & EBook \\
\hline Amadeo I (1910) & Amedeo I (2015) & $\begin{array}{l}\text { Rovato, Pensa } \\
\text { multimediale }\end{array}$ & $\begin{array}{c}\text { Antonio } \\
\text { Boccardo, } \\
\text { Diego Simini }\end{array}$ & $\begin{array}{l}\text { Colección } \\
\text { "La quinta del } \\
\text { sordo" }\end{array}$ \\
\hline
\end{tabular}




\begin{tabular}{|c|c|c|c|c|}
\hline \multicolumn{5}{|c|}{ T A B L A (CONTINUACIÓN) } \\
\hline Alceste (1914) & Alceste (2010) & $\begin{array}{c}\text { Roma, Nuova } \\
\text { Cultura }\end{array}$ & $\begin{array}{c}\text { Trinis Maria } \\
\text { Antonietta } \\
\text { Fajardo }\end{array}$ & \\
\hline $\begin{array}{c}\text { Memorias de un } \\
\text { desmemorado } \\
\text { (1915-16)/ } \\
\text { escritos/cuentos }\end{array}$ & $\begin{array}{l}\text { Memorie di uno } \\
\text { smemorato ed altri } \\
\text { scritti (2020) }\end{array}$ & $\begin{array}{l}\text { Palermo, } \\
\text { UniPaPress }\end{array}$ & $\begin{array}{c}\text { Maristella } \\
\text { Mazzara, } \\
\text { Domenica } \\
\text { Crapanzano, } \\
\text { Fernanda } \\
\text { Macchiarella }\end{array}$ & $\begin{array}{c}\text { Col. } \\
\text { "TransLitterae" } \\
\text { (en prensa). } \\
\text { Introd. Assunta } \\
\text { Polizzi }\end{array}$ \\
\hline
\end{tabular}





\title{
CAPÍTULOV
}

\author{
Los retos sociales, históricos y culturales de las dos traducciones inglesas de la novela \\ Tormento de Benito Pérez Galdós (1884), \\ Torment (1952) e Inferno (1998)
}

Juan Miguel Zarandona

Universidad de Valladolid

\section{INTRODUCCIÓN}

La Barcelona y la España de 1985 conoció una segunda edición especial —la primera se dio a conocer dos años antes, en 1983- de un volumen que reunía dos novelas de D. Benito Pérez Galdós (1843-1920), por este orden no cronológico: Tristana (1892) y Tormento (1884). Se trató de una iniciativa de la editorial Mundo Actual de Ediciones destinada en exclusiva a los socios de Discolibro, empresa especializada en la venta por correspondencia de los productos que su mismo nombre indica.

Las páginas del libro no explicitan, al carecer de paratextos, las causas de la decisión comercial de agrupar estas dos novelas, entre las muchas posibles que nos donó Galdós, ${ }^{1}$ y proponerlas para sus lectores aficionados a la lectura, pero no cabe duda de que el estreno de la versión cinematográfica de Tristana en $1970,{ }^{2}$ con el mismo título, dirigida por el ya entonces considerado genial artista del celuloide Luis Buñuel ${ }^{3}$ tuvo que pesar en gran manera en la decisión tomada. ${ }^{4}$ Tristana, la película, fue una exitosa coproducción

1 Para introducción o mayor conocimiento de la vida y obra de Galdós se recomienda, en primer lugar, la biografía de Bravo Villasante (1979), muy bien documentada y con gran aparato de fotos, una completa cronología (263-268) y un listado cronológico de sus obras (269-289). Sin embargo, la biografía de referencia de hoy en día tal vez sea la del reputado investigador galdosiano Ortiz Armengol de 1996, con una edición abreviada de 2000 del mismo título: Vida de Galdós. Ello con el permiso de las que se han publicado en torno a la celebración del centenario del fallecimiento del autor, por ejemplo, las de Cánovas Sánchez (2019) o Arencibia (2020).

2 En España Tristana, por razones políticas y de censura, no se estrenó hasta el 16 de agosto de 1974.

3 La adaptación cinematográfica de Buñuel de la novela galdosiana distó mucho de ser literal y ya el propio cineasta advirtió en los títulos de crédito que solo se había inspirado en el texto escrito de D. Benito y que introdujo todo tipo de modificaciones: temporales, espaciales, argumentales y de voz narrativa (Gonzálvez y Sevilla 2008: 80).

4 Luis Buñuel siempre se mostró como un gran admirador de Benito Pérez Galdós del cual, aparte de Tristana, llevó a la pantalla dos otros títulos, su llamada "trilogía galdosiana»: Nazarín, novela de 1885 y película homónima de 1959; y Halma, de 1895, titulada Viridiana, de 1961, en el cine. Para mayor información véase Bikandi-Mejías (1997) y Navarrete (2003). 
internacional (España, Italia y Francia) dotada de un brillante reparto encabezado por Catherine Deneuve (1943- ), Fernando Rey (1917-1994), Franco Nero (1941- ) y Lola Gaos (1921-1993), que recibió infinidad de premios con los que acrecentar su rico palmarés y que estuvo nominada al Óscar a la mejor película de habla no inglesa de 1970. Desde aquel entonces, Tristana, tal vez junto a Fortunata y Jacinta, ha logrado auparse al primer puesto de la popularidad entre las obras de Galdós, con méritos indiscutibles. ${ }^{5}$ Por ello, la elección de este clásico moderno, tan popular, para el perfil de los seguidores de Discolibro, seguramente no pudo ser más acertada. Todo ello explica que esta novela se situara en primer lugar y que una supuestamente cariñosa foto de Tristana-Catherine Deneuve y Don Lope-Fernando Rey ocupe la portada como perfecto reclamo.

Y después del reclamo, el refuerzo, es decir, la segunda novela del volumen: Tormento (1884), anterior, por lo tanto, por su momento de publicación original. Sin mucho riesgo a equivocarnos, creemos que no sé trató de una mera coincidencia, pues el cine también pudo tener mucho que ver en esto, ya que se dio la feliz circunstancia de que esta novela, que en nada desmerece a Tristana, como trataremos de defender en estas páginas, también fue adaptada al cine, con título homónimo, en el año 1974, el mismo del estreno real de Tristana en España, lo cual fue sin duda un aliciente muy favorable para su caminar hacia la gran pantalla. La dirección le correspondió al prestigioso director espańol y del cine español, Pedro Olea (1938- ), y con un reparto excepcional de protagonistas: Ana Belén (1951- ), Francisco Rabal (1926-2001), Javier Escrivá (1936-1996) y Concha Velasco (1939-), sin hacer de menos a multitud de geniales secundarios galdosianos.

Pero, según nuestro parecer, el cine no lo fue todo. La suma o diálogo de ambas novelas fue todo un acierto por otras muchas razones, ya fueran estas conscientes o inconscientes. Las dos narraciones presentan dos títulos breves, en realidad, dos nombres enigmáticos de connotaciones desasosegantes (la tristeza y el tormento) de una sola palabra de ocho letras que sugieren una clara aliteración de consonantes dentales sordas y nasales, y detrás de los cuales se encierra la clave para entender los sentimientos más profundos que atenazan a sus dos protagonistas femeninas y a los dilemas a los que la vida les enfrenta: "Tristana», un nombre de ribetes literarios caballerescos, ${ }^{6}$ aunque parezca un seudónimo; la folletinesca «Tormento», 7 un seudónimo que esconde otro nombre, Amparo. En estas dos novelas de estudio de la personalidad femenina enfrentada al abuso y al infortunio, ${ }^{8}$ dichas dos mujeres participan en unos elaboradísimos triángulos (de una mujer y dos varones) de amor, miedo, pecado, odio y poder abiertos a océanos de geniales posibilidades interpretativas como solo don Benito era capaz de pergeñar.

5 Para una revisión novedosa de las posibles intenciones caballerescas de Tristana, véase Zarandona (2019: 681-705).

6 Según comenta Whiston (1999: 11), es un hecho bien conocido que Galdós poseía una gran biblioteca personal que le permitió ponerse al tanto con todas las corrientes intelectuales y artísticas de su tiempo, incluido el renacer de la literatura caballeresca y artúrica medievalizante del siglo XIX (Zarandona 2019: 681-705). Por otra parte, sus lecturas de la literatura española de los siglos anteriores y sus intertextualidades con ella han sido ampliamente estudiadas y admiradas (Benítez 1992).

7 El folletín era uno de los géneros literarios que dominaba el gusto de los lectores en tiempos de Galdós (Ynduráin 1970: 56). Tormento recuerda muchas de las extremadas características del mismo (Andreu 1979: 315-320).

8 A Galdós se le ha considerado el primer escritor español en introducir, en plano de igualdad con el hombre, a una galería tan completa de mujeres en su mundo literario (Zambrano 1989: 188), con 
Es decir, los tres vértices de Tristana, Don Lope y Horacio de la primera frente a los otros tres de la segunda: Tormento (Amparo), Agustín Caballero y D. Pedro Polo. Las dos narraciones ejemplares encierran muchos más puntos en común de los que se podrían sospechar en un primer vistazo, lo cual convierte en una gran elección su publicación conjunta. ${ }^{9}$

\section{LAS TRADUCCIONES INGLESAS DE TRISTANA Y TORMENTO}

Aunque no lo suficiente para los muchos admiradores del escritor canario, ${ }^{10}$ al no existir en ninguna lengua las obras completas en traducción del mismo ${ }^{11}$ lo cierto es que se ha de reconocer que un número notable de sus obras ha sido traducido a una variedad amplia de lenguas extranjeras. Entre estas se encuentra Tristana, que junto a Fortunata y Jacinta y alguna otra obra, es una de las que contabilizan más traducciones, en su caso a idiomas como los siguientes: alemán, árabe, búlgaro, danés, francés, griego, holandés, inglés, italiano, portugués, rumano, ruso o serbio, al menos. Además, en muchas de estas lenguas existe más de una traducción, es decir, se ha producido el fenómeno de la «retraducción». La novela Tormento, por el contrario, no ha sido nunca tan exitosa pero no por ello no conoce esta obra un buen número de traducciones a lenguas como el árabe, holandés, chino, francés, italiano e inglés.

las que siempre suele mostrar una actitud compasiva y comprensiva hacia su condición de mujeres y frecuentes víctimas de su medio (Acosta de Hess 1988: 94). Ello no ha impedido que no se le haya achacado una posición ambigua, si no fría, de la cuestión de la emancipación de la mujer (Vilarós 1995: 1).

9 A pesar de las muchas ediciones bajo iniciativa de un gran número de editoriales, no hay duda de que el mayor difusor contemporáneo de las obras de Galdós en general y de Tormento en particular, ha sido Alianza Editorial. Entre 1968 y 1996 esta novela que nos ocupa conoció veinticuatro reimpresiones en la colección El Libro de Bolsillo. Desde 1997 se siguió publicando en una nueva colección: Biblioteca de Autor / Biblioteca Pérez Galdós, hasta la fecha, con un número igual de frecuente de reimpresiones hasta alcanzar un total cercano a cuarenta de ellas.

10 Lo cierto es que el prestigio de Galdós como literato estuvo muchos años en duda debido a las nuevas modas literarias de vanguardia que no llegaron a apreciarlo ni a valorar su obra. Recuérdese el apelativo despectivo de Valle-Inclán en su Luces de Bohemia (1920), del mismo año del fallecimiento del novelista: «Don Benito, el garbancero» (Moreno Hernández 2007: 55). La recuperación no se produjo hasta los ańos de la República y la Guerra Civil, cuando por razones ideológicas se le consideró el «campeón del pueblo». Finalmente, el centenario de su nacimiento en 1943 supuso la consolidación de su recuperación e incondicional aprecio con una publicación simbólica: Vida y obra de Galdós (18431920) de Joaquín Casalduero, publicada ese año en Buenos Aires y que no se editó en Madrid hasta 1951 (Varey 1970: 1-35). Por supuesto, estas circunstancias no ayudaron a su prestigio exterior ni al auge de las traducciones de su obra durante muchos años. Hoy en día se trataría de algo que ya ha cambiado en gran medida al haberse convertido su estudio en una auténtica moda entre los hispanistas nacionales y extranjeros, en especial en Estados Unidos (Sopeña Ibáńez 1970: 10).

11 Por lo que respecta al español Ortiz-Armengol se quejaba este en 1996 de que no existían todavía unas verdaderas obras completas en español (7). Igualmente, reconoce que una biografía tan completa como la suya es muy tardía, hecho que pone en contraste con la completísima que se le dedicó a Charles Dickens a los cuatro ańos de su fallecimiento, aunque haya que admitir como disculpa que Galdós fue siempre muy reservado con los detalles de su vida y que no gustaba nada de hablar de sí mismo. Esto también fue en contra de su prestigio nacional e internacional y de la necesidad posterior de recuperar su figura (1996: 9-16). 
Ocuparía, como otros muchos títulos galdosianos, una posición intermedia de éxito traductor. $^{12}$

Si nos ceñimos al inglés, es posible beneficiarse de dos traducciones de Tormento publicadas ambas en el siglo XX, lo que permite abordar un análisis descriptivo y comparativo entre ambas propuestas entre sí y de las mismas y su original. Este será el objetivo fundamental de este capítulo con la vista puesta en conocer a Galdós, por medio de una de sus obras más atractivas, a través de la interpretación y dificultades sufridas por sus traductores ingleses y llegar a conocer si estos aplicaron normas reconocibles de traducción (Toury 1995: 53-69), coherentes o, incluso, dispares entre sí. Como primera hipótesis podemos proponer que las diferencias sociales, históricas y culturales entre los contextos del original y los de estas traducciones de 1952 y 1998, muy tardía esta última, tuvieron que jugar un papel decisivo en la producción de los nuevos textos. ${ }^{13}$

\section{TORMENTO EN INGLÉS}

Como ya se ha avanzado en el apartado anterior, la novela Tormento de Galdós se ha traducido en dos ocasiones al inglés, durante el siglo XX, en 1952 y en 1998, en el Reino Unido.

\subsection{Torment, la traducción de J. M. Cohen de 1952}

Esta novela de 1884 tardó sesentaiocho años en ser traducida por primera vez al inglés, treintaidós años después del fallecimiento del autor en Madrid en 1920, lo que indica un cierto fracaso o, más bien, pobreza de recepción. ${ }^{14}$ La edición de esta traducción viene acompañada de dos paratextos fundamentales, aunque muy breves: a) una breve reseña sobre el autor y su obra que aparece en la solapa anterior del libro y que resulta muy insuficiente; $y$ b) una nota del traductor (Translator's Note) que comenta alguna de sus decisiones a la hora de verter el texto, que de nuevo desearíamos que hubiera sido más prolija (Galdós 1952a: 7). Además, la edición incluye una colección de nueve grabados, el primero destinado a la portada y los ocho restantes situados en página interiores (Galdós 1952a: 2, 57, 97, 112, 176, 193, 288, 305).

Si leemos con atención el primer paratexto, se aprecia, junto a la devota alabanza: "Torment is a fascinating period piece but goes far beyond it and can claim to rank as a timeless and moving study of character» (Galdós 1952a: solapa delantera), que el traductor se esfuerza en dar la bienvenida a la lengua y cultura británicas e incluir al autor español dentro del canon conocido de los grandes escritores europeos de los siglos XIX y XX: Dickens, Dostoevsky (sic), Maupassant y, sobre todo, Balzac: "The scene is set in nineteenth-century Madrid. Galdós's description of Spanish society, high and low, his

12 Para mayores datos consúltese la bibliografía de las traducciones de la obra de Pérez Galdós, recopilada por Isabel Pascua Febles e Isabel García Bolta, que se incluye en las páginas del presente volumen en torno a Benito Pérez Galdós y la traducción.

13 Este trabajo también buscará paliar en alguna medida el desigual éxito de recepción de Tristana, (crítica y traducción literaria o doblaje) novela y película, respecto a Tormento, mucho menor el de esta última.

14 El mismo libro se publicó un año después (1953) en Nueva York por la casa Farrar Straus \& Young. 
meticulous, almost microscopic, examination of people's behaviour and motives, vanities, ambitions, endearing weaknesses, recalls the technique and range of Balzac's Comédie Humaine» (Galdós 1952a; solapa delantera). Sorprende un poco el hecho de que a mediados del siglo XX todavía fuera necesario presentar al escritor español y persuadir de su valía, pero seguramente era una realidad que solo la traducción podía superar. ${ }^{15}$

La nota del traductor contiene una afirmación de gran interés, al recordar que se acababa de traducir al inglés la novela La de Bringas (1884), tan relacionada con Tormento, ${ }^{16}$ por sus personajes y hechos comunes, con el título de The Spendthrifts, traducción de Gamel Woolsey, y publicada un año antes, 1951, por la misma editorial: ${ }^{17}$ "This translation may differ in slight details from Miss Gamel Woolsey's of the Spendthrifts. Unlike her, I have made no attempt to anglicize any of the proper names; and it is possible also that in naming titles, institutions, government departments and other things for which there is no fixed English equivalent my practice has differed from hers» (Galdós 1952a: 7). Nos será muy necesario prestar atención a la traducción de todos estos nombres propios en secciones venideras de este capítulo.

En tercer lugar, ya se ha mencionado que contamos con nueve ilustraciones del profesor de arte y afamadísimo y muy prolífico artista, grabador e ilustrador de libros Charles Alfred Mozley (1914-1991), protagonista de su gremio de la Inglaterra del siglo XX. Estos grabados, con sus cuidadas reconstrucciones de las calles y de las viviendas del Madrid galdosiano de la época, así como de sus iglesias y otros edificios, de la decoración de interiores del momento, del peinado y vestuario de damas y caballeros, de abanicos y mantillas a elegantes chisteras, son un auténtico testimonio documental y una gran ayuda tanto para los lectores de la traducción, como también para los del original.

Pero, ¿quién fue el traductor que se responsabilizó de esta tarea de producir este texto en inglés? No podemos olvidarnos de conocer al ser humano detrás de su obra, sobre todo porque nos encontramos ante unos de los traductores más prestigiosos del siglo XX británico, John Michael Cohen (1903-1989). Licenciado por la Universidad de Cambridge, profesor, investigador y, sobre todo, traductor desde el ruso (Boris Pasternak), del francés (Rabelais, Montaigne) y muy especialmente desde el español: tanto de los clásicos del Siglo de Oro (Francisco de Rojas, Cristóbal Colón, Bernal Díez o Santa Teresa) o iberoamericanos (Jorge Luis Borges, Octavio Paz o Carlos Fuentes). Su obra cumbre de traducción fue su Don Quixote para la editorial Penguin publicado en 1950 y que fue extremadamente popular. ${ }^{18}$ Todo el mundo le reconoció ya en vida, y sigue haciéndolo, que realizó una labor inmensa para abrir al lector de lengua inglesa a los clásicos de

15 En 1998 se publicó una monumental recopilación bibliográfica de estudios sobre Galdós (Herrera Navarro). Se incluyen un total de cuarentaiséis referencias que tratan sobre Tormento, desde la entrada 4102 hasta la 4147 (333-336). Sin embargo, no se incluyen traducciones de este texto ni de ningún otro. Se trataba entonces y ahora de una carencia muy sentida.

16 Ambas novelas del mismo año comparten el personaje de Rosalía Papión de la Barca, señor de Bringas, uno de los ejemplos más logrados del magistral uso de la ironía por parte de Pérez Galdós, muy crítica hacia sus pretendidas virtudes en este caso (véase Urey 1982: 5-6, 36).

17 E igualmente un año después en Nueva York por la editorial que ya publicara Torment en aquel país, Farrar Straus \& Young.

18 En esto coincidieron autor y traductor, en su cervantismo, tan estudiado y encomiado en la obra de Galdós, llamado el heredero de Don Miguel (Gullón 1970; 1973: 58-60). 
la literatura universal. Ese fue su mayor legado. La novela Tormento de Pérez Galdós no pudo caer en mejores manos.

\subsection{Inferno, la traducción de Abigail Lee Six de 1998}

Cuarentaiséis años tuvieron que trascurrir para que otra británica se atreviera a traducir de nuevo Tormento en el Reino Unido, y osara competir con J. M. Cohen. La protagonista fue en esta ocasión la profesora Abigail Lee Six (1960- ), directora entonces del Department of Hispanic Studies and Italian en el Queen Mary and Westfield College, de la Universidad de Londres, especialista en ficción española de los siglos XIX y XX y una investigadora muy prolífica y admirada.

La traducción incluye un prólogo (Foreword) (Pérez Galdós 1998: vii-xii), que en un determinado pasaje establece y confirma su independencia respecto a la primera versión del prestigioso hispanista británico:

«The present translation is based on the first edition of Tormento, edited by
Easmonn Rodgers (Oxford: Pergamon, 1977). His notes and personal advice
were an invaluable resource in the preparation of this English version. The
earlier translation, Torment, by J. M. Cohen (London: Weidenfeld \&
Nicolson, 1952) was consulted for comparative purposes, but in no way
served as a basis for this version, which is my own (Pérez Galdós 1998: x)».

Creemos que se puede defender, sin miedo a equivocarse, que el revolucionario cambio de título, de Torment a Inferno, se debió a la necesidad de reivindicarse y de diferenciar su traducción de la del maestro Cohen. En esta publicación el seudónimo de Amparo Sánchez Emperador, la protagonista, será «Inferno», no «Tormento / Torment», de acuerdo al nuevo título. La decisión de este cambio afecta, en consecuencia a todo el texto.

Aparte de todo esto, el prólogo se compone de dos partes, una primera más literaria donde se vuelve a insistir en el abandono internacional, o más bien angloamericano, de Galdós y se le compara con los maestros consagrados europeos (recuérdese que ya estamos en 1998): "In spite of his relative obscurity in the English-speaking world, in Spain Benito Pérez enjoys a status analogous to that of Dickens here or Balzac in France» (Pérez Galdós 1998: viii). Por supuesto, se introduce brevemente al público lector de lengua inglesa a datos tan relevantes y pertinentes como la enorme obra del autor, la necesidad de seguir estudiando parte de ella, el prestigio alcanzado sobre todo por sus así llamadas novelas contemporáneas, ${ }^{19}$ su realismo insobornable, ${ }^{20}$ su uso magis-

19 Galdós aplica el término contemporáneas a sus novelas a partir de La desheredada (1881) hasta alcanzar el año 1915 de su La razón de la sinrazón, un conjunto total de veinticuatro textos, entre los que se encuentran sus títulos más conocidos (Gullón 1970; 1973), y en los que busca un alejamiento del pasado histórico y ocuparse de la realidad española del presente (Benítez 1990: 63). Tormento es buen ejemplo de ello (Comellas Aguirrezábal 2010: 131-182).

20 Respecto al realismo, la traductora, Abigail Lee Six, también comenta que en Tormento, dicho realismo se tiñe de otros dos géneros próximos, el folletín (melodramatic serial), representado por el personaje de Ido del Sagrario, y el drama teatral de similares características que tanto gusta a otro de los personajes, Rosalía de Bringas (Pérez Galdós 1998: ix). 
magistral de la ironía ${ }^{21}$ o al momento histórico donde se localizan los hechos narrados en su Inferno:

«A prolific writer, Galdós produced a total of 78 novel and 21 plays, in addition to his journalistic work. Although his other writing is now beginning to receive more critical attention, it remains true that Galdós's fame is mostly atributable to the group of fictional works to which Inferno belongs, called by some critics the 'Social Novels' and all written between 1870 and 1915. Despite their fictional status, however, these narratives are inextricable bound up with the sociopolitical climate of their author's lifetime and ingeniouly weave historical events and personages into their fabric. [...] Inferno was published in 1884 [...] However, Inferno's setting backtracks 17 years to cover the period of November 1967 to February $1868 .{ }^{22}$ This was a time of political turmoil whick would culminate in September 1868 in the so-called Glorious Revolution, when Queen Isabella II (1833-68) was dethroned [...] One of the joys of reading Galdós is undoubtedly his masterful use of irony. Inferno is no exception in this respect (Pérez Galdós 1998: vii-ix)».

La segunda parte del prólogo, titulada «Notes on reading Inferno in Translation» (Pérez Galdós 1998: x-xii), por el contrario, se centra en cuestiones de diferencias culturales y de estilo de vida además de otras de método traductor, al tiempo que se aporta una relación de las decisiones que ha considerado necesario resaltar. En pocas palabras, los siguientes puntos que tendremos muy en cuenta en secciones posteriores cuando abordemos el cotejo de ambas traducciones de Tormento al inglés, a la luz del original galdosiano:

1) En España la población urbana, incluso el sector más privilegiado, vive en pisos no en casas individuales como es la norma en Gran Bretaña. Eso sí, cuanto más pobres en niveles más altos, siendo el más elegante el bajo o principal.

2) La palabra española casa es un término muy poco preciso y ha sido necesario traducirlo por diferentes equivalentes ingleses, dependiendo del contexto: house, home, abode, building, ya que este campo semántico es mucho más rico en inglés que en español.

3) Los espańoles usan dos apellidos, entonces y ahora, aunque no siempre, de manera informal se usan los dos en todas las ocasiones, y cuando las mujeres se casan no pierden sus apellidos para adoptar el de sus maridos, al menos oficialmente, aunque a veces también se les conoce por el de aquellos: «Sra. de ...».

21 Como ya se ha comentado, Cervantes fue una poderosa influencia en las novelas de Pérez Galdós, en especial la de su magistral uso de la ironía que le permitió al canario potenciar su talento propio para este sofisticado recurso literario que surge a lo largo de toda su carrera de escritor (Urey 1982: 1-4).

22 Ciertamente, aunque Tormento se escribió en 1884, los hechos narrados tuvieron lugar entre los años 1867 y 1868, meses antes de la revolución que destronó a la reina Isabel II en septiembre de 1868. 
4) Es muy difícil conservar en inglés solo por el empleo añadido de títulos junto a los nombres (miss para Amparo, por ejemplo), las implicaciones emotivas y sociales del uso del usted o del tú en las fórmulas de tratamiento entre las personas.

5) También resulta todo un reto traducir la carga irónica, incluso sarcástica, de algunas expresiones españolas con artículo: «La de Bringas» / «our dear Mrs Bringas», o «La Emperadora» / «our Emperine».

La traductora, Abigail Lee Six, se muestra, como podemos ver gracias a estos comentarios, como una profesional muy atenta a diferencias culturales, tanto urbanísticas, onomásticas como lingüístico-pragmáticas, pero, además, prefiere aclararlas a sus lectores antes que neutralizarlas, por mucha extrañeza o confusión que susciten en ellos. De esta manera, consigue acercar la realidad de la sociedad madrileńa de la época de manera más efectiva a los interesados en su traducción, por muy exótica que resulte, en vez de caer en la tentación de la neutralización del texto meta, la exigencia de la fluidez, la ocultación de que se trate de una traducción o la invisibilidad de la traductora. ${ }^{23}$

\section{Metodología}

Como se ha recogido en el apartado anterior, el primer traductor, J. M. Cohen (1952), afirma en sus paratextos que no ha buscado anglicanizar los nombres propios españoles a diferencia de una traductora anterior de otra obra de Galdós, sobre todo cuando no se cuenta con una equivalencia ya fijada para su traducción al inglés. El otro rasgo distintivo de su texto lo constituye, sin duda, los nueve grabados ya mencionados, una gran ayuda para el lector británico.

Por lo que respecta a la segunda traductora, A. L. Six (1998), cabía resaltar, en primer lugar, su atrevido cambio de título y, en consecuencia, de apodo de la protagonista, de Torment a Inferno. Y en segundo, los comentarios que expresa sobre las principales diferencias culturales que le han supuesto mayor dificultad: los diferentes tipos de vivienda y como el vocabulario inglés es mucho más rico y variado al respecto; el uso diferente de los nombres propios de persona entre ambas lenguas y culturas; los matices en las formas de tratamiento y el uso de usted en español. Aparte, el reto de interpretar y verter correctamente el magistral uso de la ironía tan propio de don Benito.

Estos indicios pueden ponerse en con parámetros propuestos por Baker (1997: 1081) y desarrollados por Kruger, Wallmach y Sanderson (2003: 120-130), bajo la denominación general de «estrategias de traducción de palabras y frases cuando se producen problemas de falta de equivalencia», en concreto las seis siguientes:

1) Substitution (proper translation)

a. Direct transfer (an SL word is replaced by a TL word with the same meaning).

b. Using a cultural substitute.

c. Using a functional substitute.

d. Using a more general word or the superordinate term for ST word.

e. Using a more neutral or less expressive word for ST word.

23 Para mayor información véase: Venuti (2002). 
f. Using an idiom of similar meaning and form.

g. Using an idiom of similar meaning but dissimilar form.

2) Repetition

a. Direct repetition (a word in the SL is repeated in the TL, e.g. names.

b. Using a pure loan word.

c. Using an indigenised loan word.

3) Deletion or omission

4) Addition, in the form of

a. Paraphrase

b. Loan word + explanation

5) Compensation (e.g. preface, footnotes, endnotes)

6) Illustrations

En apariencia, Cohen parece optar entre un equilibrio entre la sustitución y la repetición, aparte de apreciar el valor de las imágenes como apoyo para la comprensión del texto traducido. Six, igualmente, es muy consciente de los problemas de falta de equivalencia, aunque no adelanta cuál será su norma de traducción. Por ello, ofreceremos en la siguiente sección de este trabajo una aproximación a un número amplio de ejemplos cuya descripción y análisis nos sirvan para resolver estas dudas. La ordenación de dichos ejemplos se amoldará a las seis estrategias mencionadas.

\section{DOS TRADUCCIONES COMPARADAS}

Para apreciar los puntos comentados en el apartado anterior, ofreceremos en el presente una colección de ejemplos, fruto de una lectura muy atenta, que consideramos altamente significativos y que girarán, sobre todo, en torno a diferencias culturales y de formas de vida del Madrid de entonces y los receptores británicos del siglo Xx; los desajustes semánticos entre palabras que no necesariamente significan lo mismo; los nombres propios de persona y lugar, así como los títulos, fórmulas de tratamiento o el tuteo; o el uso de la ironía tan propio de Galdós. ${ }^{24}$

En primer lugar, dentro de cada apartado se presentarán fragmentos de texto procedentes del original de Pérez Galdós, de acuerdo a la edición académica de 2007 de Tormento, ${ }^{25}$ que contengan algunos de estos retos enfatizados por J. M. Cohen y Abigail Lee Six; en segundo, las traducciones de los mismos en el texto inglés de 1952; y, finalmente, en el texto de 1998.

24 Respecto a este último rasgo, conviene recordar de nuevo el origen cervantino de tal talento (Benítez 1990: 14).

25 La amplia introducción de esta edición recoge la historia textual de la novela de la siguiente manera: «Tormento se editó en vida de Galdós en cinco ocasiones: dos en 1884, una en 1885, una en 1888, y la última en 1906. Tras la muerte del escritor, Hernando lo reeditó en 1933. A partir de $1941 \mathrm{em}$ piezan las impresiones de Aguilar (primero en los volúmenes de obras completas, luego en la colección Crisol); y de 1968 en adelante, las de Alianza, sin duda las de mayor difusión. Ahora bien, conviene saber que de esta novela se nos han conservado tanto el manuscrito como las galeradas, y que ambos documentos son inapreciables para observar cómo construía Galdós sus textos» (Barjau y Parellada 2007: 20). 


\subsection{Sustitución}

\section{EJEMPLO 1:}

Resulta curioso poner en contraste la traducción más literal de «arroz a la valenciana» de la primera traducción de 1952 y el atrevimiento de la segunda, de 1998, que le da nombre a dicho plato (algo que no hizo Galdós) en unos ańos en que la palabra "paella» era ya muy conocida en el mundo entero. Desde luego, entre los lectores británicos:

Hacía el café en la cocina a estilo de gastrónomo, y si le apuraban, comprometíase a poner un arroz a la valenciana que superara a las mejores obras de su digna esposa y de la cocinera de la casa (Pérez Galdós 2007: 147).

He could go into the kitchen and make coffee like an expert, and at a pinch he could undertake a dish of Valencian rice that beat the finest performances of his worthy wife or their cook (Pérez Galdós 1952a: 20).

He made coffee in the kitchen like a true gourmet and if pressed, could be persuaded to make a paella that surpassed the best work of his noble wife and the house cook (Pérez Galdós 1998: 11-12).

\section{EJEMPLO 2:}

Lidiamos ahora con una expresión idiomática o modismo: «mueve esos remos», la cual es neutralizada en 1952 donde solo se conserva el contenido, o sustituida por otra más o menos equivalente en 1998: «You are not pulling your weight», en un esfuerzo más o menos exitoso de combinar la chispa y casticismo del original. A diferencia de lo anteriormente analizado, el atrevimiento en esta ocasión se inclina por la segunda traductora:

«Por Dios, Prudencia, mueve esos remos... ¡qué pasma!... Es una desesperación... ¡Qué siempre he de estar yo rodeada de gente inútil!» (Pérez Galdós 2007: 154).

"Good Lord, Prudencia, do move yourself... How lazy you are!... It's unbearable... Why do I always have to be surrounded by useless people!" (Pérez Galdós 1952a: 26).

'For goodness' sake, Prudencia, you're not pulling your weight... This is so tiresome!... It's enough to drive one to despair... Why must I always be surrounded by people like this?' (Pérez Galdós 1998: 16).

\section{EJEMPLO 3:}

Las versiones para traducir el modismo «hacer el pollo», son muy distintas e imaginativas, aunque tal vez no puedan seguramente mantener el casticismo humorístico tan madrileño del original. Se ha luchado pero no se puede afirmar que se haya conseguido sin lugar a dudas:

-Ya comprendo, sí... Pero no se te pide que hagas el pollo; lo que se te pide es...» (Pérez Galdós 2007: 176).

"I understand, of course... but no one's asking you to play the young man; what one does ask..." (Pérez Galdós 1952a: 45). 
Point taken, yes... But we're are not asking you to be a young dandy; all we’re asking...' (Pérez Galdós 1998: 31).

\section{EJEMPLO 4:}

Este ejemplo suscita la misma duda, pero dentro del terreno de la organización de la jornada y la distribución de las comidas a lo largo de la misma. Una merienda, sobre todo para unos niños espańoles hambrientos que vuelven del colegio, nunca será un snack ni un tea time, pero tal vez no mucho más se podía hacer, por supuesto:

—La merienda, mamá, —clamaron los dos a un tiempo. — La merienda, mamá, -repitió Caballero, tomando a cada uno de una mano y saliendo con ellos hacia el comedor (Pérez Galdós 2007: 180).

"Our snack, our snack, Mamma," shouted the pair in unison. "Our snack, Mamma," repeated Caballero, taking both of them by the hand and leading them to the dining-room (Pérez Galdós 1952a: 49).

'Tea time, Mama,' they both clamoured simultaneously. 'Tea time, Mama,' repeated Caballero, taking each by the hand and heading towards the dining room with them (Pérez Galdós 1998: 34).

\section{EJEMPLO 5:}

De nuevo los traductores vuelven a enfrentarse con un reto culinario muy difícil de superar con éxito. ¿Puede un cake o un bun traducir una «mantecada de Astorga»? Estas fueron las discutibles opciones elegidas:

«Toma - le dijo a Rosalía saliendo de la despensa y entregándole con ademán espléndido dos mantecadas de Astorga... (Pérez Galdós 2007: 212).

"Here's something for you," said Rosalía, emerging from the larder and handing her with a splendid gesture two Astorga cakes... (Pérez Galdós 1952a: 77).

'Here,' said Rosalía, coming out of the larder and with a magnanimous flourish handing her two Astorga buns [...] (Pérez Galdós 1998: 54).

\section{EJEMPLO 6:}

De nuevo la primera traducción presenta una debilidad, la calle no es Ancho, aunque puede tratarse de un error tipográfico. Si resultan muy atractivas las dos versiones que proponen los traductores para la tienda de ultramarinos mencionada. En esta ocasión ambos optan por la claridad y búsqueda de claros equivalentes ingleses:

-Después entré en la tienda de la calle Ancha, ya sabe usted, el número 17, donde dice: Ultramarinos de Hipólito Cipérez (Pérez Galdós 2007: 226). "After that I went into the shop in the Calle Ancho, you know it, No. 17 Hipólito Cipérez, it says, imported goods (Pérez Galdós 1952a: 90).

'Then I went into the shop in Calle Ancha, you know, number seventeen, where it says: Hipólito Cipéreżs Grocery (Pérez Galdós 1998: 65).

\section{EJEMPLO 7:}

El inglés no posee la capacidad lingüística de la distinción entre el usted y el tú, el llamado tuteo; se trata de un contraste muy conocido respecto a las lenguas románicas. A 
ello se refieren Agustín Caballero y Amparo Emperador en cierto momento de sus relaciones. ${ }^{26}$ Los traductores tratan de explicarlo a sus lectores ingleses de la mejor manera que les es posible, aunque difícilmente podremos afirmar que estos entendieran sus significativas sutilezas, tan explotadas por Galdós a lo largo de toda la novela:

«Otra cosa... - - dijo temblando dentro de su capa-. ¿No le parece a usted que nos tuteemos?». Este brusco proyecto de confianza asuntó un tanto a la Emperadora, que... se echó a reír. «Me parece —observó- que me será difícil acostumbrarme» (Pérez Galdós 2007: 297).

"Another thing..." he said, trembling inside his cape. "Don't you think that we might say tú to one another?” This brusque proposal of intimacy so surprised the late Señor Emperador's daughter that she burst out laughing. "I think," she observed, "that I should find it difficult to get used to" (Pérez Galdós 1952a: 158).

'Another thing...' he said, trembling under his cloak. 'Don't you think we could use the familiar?' This sudden proposal of closeness took our Emperine so much by surprise that she burst out laughing. 'I think,' she observed, 'it'll be hard for me to get used to' (Pérez Galdós 1998: 119).

\section{EJEMPLO 8:}

Otra muestra de palabra española muy tradicional y típica, picara, que se omite y se trata de sustituir por un equivalente más o menos acertado. Los resultados están a la vista:

¡La muy pícara no había ido desde el sábado!... Estaba endiosada. Hacer quería ya papeles de humilladora, por venganza de haber sido tantas veces humillada (Pérez Galdós 2007: 315).

The young wretch had not been there since Saturday!... She was elated with pride, and wanted to play the role of humiliator, out of revenge for having been humiliated so often (Pérez Galdós 1952a: 174).

The little monkey hadn't been since Saturday!... She'd grown vain. She wanted to play the role of humiliator now, to take revenge for having been so often humilated (Pérez Galdós 1998: 133).

\subsection{Repetición}

\section{EJEMPLO 9:}

Ninguno de los dos traductores evita la reproducción de nombre tan complejo para los oídos británicos, como «don Francisco de Bringas y Caballero», con título, prepo-

26 Como los lectores de Tormento fácilmente aprecian, Agustín va moldeando poco a poco y a su gusto a su futura esposa Amparo: vestimenta, estilo de vida, rutinas, conversaciones, etc. Al respecto, Alan S. Smith defiende que las novelas de Galdós, además del estricto realismo, esconden una segunda lectura mitológica de raíz romántica. Se cita especialmente el mito de Pigmalion que estaría presente en títulos como La familia de León Roch (1878), La desheredada (1881), El amigo Manso (1882) o Fortunada y Jacinta $(1886,1887)$ (Smith 2005: 15, 16, 89-108). Por nuestra parte nos atrevemos a añadir a este listado el título de Tormento, de 1884, es decir en el mismo periodo de estas otras novelas contemporáneas donde también reaparecería este mito. 
sición y conjunción en español; sin embargo sí traducen la institución y le dan un nombre en inglés que nunca tuvo, en lo que coinciden de nuevo los dos. Todo lo cual nos anuncia desde las primeras páginas la búsqueda de un cierto equilibrio entre la conservación de lo ajeno o su transformación para convertirlo en algo más cercano. Por esta razón este breve fragmento de texto también podría incluirse en el apartado 5.1:

Don Francisco de Bringas y Caballero, oficial segundo de la Real Comisaría de los Santos Lugares, era en 1867 un excelente sujeto que confesaba cincuenta ańos (Pérez Galdós 2007: 144).

Don Francisco de Bringas y Caballero, second officer in the Royal Commision for the Holy Places, was in 1867 an excellent fellow who admitted to the age of fifty (Pérez Galdós 1952a: 18).

In 1867, Don Francisco de Bringas y Caballero, second in command at the Royal Commission of Holy Places, was a fine fellow who admitted to being fifty (Pérez Galdós 1998: 10).

\section{EJEMPLO 10:}

En esta ocasión, el primer traductor se muestra más atrevido que la segunda respecto a los nombres propios y los tratamientos: «doña Rosalía Pipaón» y «señora de Bringas». No todo lector de lengua inglesa ha de estar familiarizado con estos juegos formales y su uso, pero se opta por esta fidelidad exotizante. La traductora de 1998 es algo más prudente en esta ocasión ya que utiliza un Mrs Bringas mucho más transparente para sus lectores:

Era nuestro buen señor excelente y aun excelentísimo padre de familia. Su mujer, doña Rosalía Pipaón, le había dado tres hijos [...] Completaban la familia una niña de diez años y un niño de nueve, herederos de las gracias maternas. Porque la señora de Bringas era una dama hermosa, mucho más joven que su marido, que en edad aventajábala como unos tres lustros (Pérez Galdós 2007: 147-148).

This good gentleman was an excellent, and more than excellent father. Doña Rosalía Pipaón, his wife, had borne him three children [...] A girl of ten and a boy of nine, who completed the family, had inherited their mother's charm. For Señora de Bringas was a beautiful woman and much younger than her husband. Indeed she had the advantage of him by fifteen years (Pérez Galdós 1952a: 20).

Our dear Mr Bringas was an excellent, even an outstanding father. His wife, Dońa Rosalía Pipaón, had given him three children. [...] The rest of the family consisted of a little girl of ten and a boy of nine, both of whom inherited their mother's graces; because Mrs Bringas was a handsome woman, far younger than her husband, who was a good decade and a half her senior (Pérez Galdós 1998: 12).

\section{EJEMPLO 11:}

Este nuevo ejemplo confirma la tendencia observada en el anterior, en esta ocasión por lo que respecta a los nombres de las calles de Madrid por donde se mueven los personajes de Tormento. El primer traductor es más opaco y cercano al original y la segunda traductora, más cercana a los lectores y a su necesidad de comprensión. En otras palabras, calle de Silva frente a Silva Street y Costanilla de los Ángeles frente Los Angeles Hill: 
A principios de noviembre, obligado Bringas, por las crecientes necesidades de la familia, a un aumento de local, se mudó de la casa de la calle de Silva, en la que había vivido durante dieciséis años, a otra en lo más angosto de la Costanilla de los Ángeles (Pérez Galdós 2007: 149-150).

At the beginning of November, forced by the growing needs of his family to seek more room, Bringas moved form the Calle de Silva, where he had lived for sixteen years, to the narrower Costanilla de los Ángeles (Pérez Galdós 1952a: 22).

At the beginning of November, Bringas was obliged, owing to the family's pressing need for more space, to move house from Silva Street, where they had lived for sixteen years, to another in the narrowest section of Los Angeles Hill (Pérez Galdós 1998: 13).

EJEMPLO 12:

Este fragmento, repleto de nombre de calles y edificios de Madrid, demuestra muy claramente que en el texto de 1952 se decidió, por prudencia tal vez, combinar los nombres originales tal como eran en el texto español, con alguna excepción adaptada al inglés, mientras el de 1998, aunque lleva a cabo la misma estrategia, se decanta por la adaptación de dichos nombres al inglés de manera más mayoritaria sin prescindir de la otra posibilidad. En realidad no se produce una gran diferencia en el resultado:

Todo lo que no sea este trocito no me parece Madrid. Nací en la plazuela de Navalón, y hemos vivido muchos años en la calle de Silva. Cuando paso dos días sin ver la plaza de Oriente, Santo Domingo el Real, la Encarnación y el Senado, me parece que no he vivido. Creo que no me aprovecha la misa cuando no la oigo en Santa Catalina de los Donados, en la capilla Real o en la Buena Dicha. Es verdad que en esta parte de la Costanilla de los Ángeles es algo estrecha; pero a mí me gusta así (Pérez Galdós 2007: 161). ${ }^{27}$

Nothing outside this little corner seems to me like Madrid. I was born in the Plaza de Navalón, and for a long time we lived in the Calle de Silva. When two days go by without my seeing the Plaza de Oriente, Santo Domingo el Real, The Incarnation and the Senate, I don't seem to have been alive. I don't think I get any benefit form the Mass unless I hear it in Santa Catalina de los Donados, or the Chapel Royal or the Buena Dicha. I admit that this part of the Costanilla de los Ángeles is rather narrow, but I like that (Pérez Galdós 1952a: 31).

Anywhere, outside this little patch, doesn't feel like Madrid to me. I was born in Plazuela de Navalón, and we lived in Silva Street for many years. If two days go by and I haven't seen Oriente Square, the Senate Building, and Santo Domingo el Real and La Encarnación, I feel as though I haven't lived. I do believe that when I hear elsewhere than at Santa Catalina de los Donados, the Royal Chapel, or Buena Dicha, it does me no good. It's true that this part of Los Angeles Hill is somewhat narrow, but I like it this way (Pérez Galdós 1998: 20).

27 No cabe duda que por todas estas calles transitaba la sociedad de su tiempo que fuera retratada con tanto ahínco por Peréz Galdós, el cual dejó muy claro lo que siempre pretendió en su discurso de entrada en la Real Academia Española de 1897. Este fue su título: La sociedad presente como materia novelable (Pérez Galdós 2013). 


\section{EJEMPLO 13:}

El mismo fenómeno puede observarse en esta nueva ocasión: la traductora de 1998 no traduce, sino que conserva la típica indumentaria femenina de las españolas, la mantilla, sepan sus lectores o no a qué tipo de prenda en concreto se está refiriendo el autor español y sin la ayuda de ilustraciones:

Este detalle pinta a la señora de Bringas, y da completa idea de su limitada inteligencia, así como de su perversa educación moral, vicio histórico y castizo, pues no lo anula, ni aun lo disimula, el barniz de urbanidad con que resplandecen, a la luz de las relaciones superficiales, muchas personas de levita y mantilla (Pérez Galdós 2007: 166). ${ }^{28}$

This detail sufficiently portrays Señora de Bringas; it gives a complete idea of her limited intelligence, and also of her perverse moral education; a pureblooded and historic vice which is neither effaced nor disguised by the gloss of urbanity with which many frock-coated and fine-shawled persons shine in the reflected glory of their superficial connections (Pérez Galdós 1952a: 35-36).

This detail characterises Mrs Bringas and gives a clear idea of her limited intelligence as well as her perverse moral education, an age-old vice of purebred Spain which is not eliminated nor even concealed by the veneer of urbanity sported for purposes of superficial relations by the vast majority of fine gentlemen if frock-coats and ladies in mantillas (Pérez Galdós 1998: 23).

\section{EJEMPLO 14:}

Los nombres de las monedas es otro referente cultural de difícil traducción. En esta ocasión el primer traductor actúa de manera contraria a lo que había hecho antes: elimina o traduce los nombres originales, salvo el conocido de peseta. Y es la segunda traductora la que conserva los nombres originales: peseta, cuarto and reals. Un ejemplo más de que no mantiene ninguno de ellos una estrategia única sino que siempre buscan, aunque de maneras diferentes, un equilibro entre neutralizar o conservar:

De esta tercera categoría rentística procedían los alambicados emolumentos de Amparo, que generalmente eran pesetas ya muy gastadas y los cuartos más borrosos [...] «Sosiégate, mujer. No le ha dado más que nueve reales... (Pérez Galdós 2007: 168-169).

From this third financial division came the distillation that fell to Amparo, which generally consisted of much worn pesetas and sedimental small coins [...] "Don't worry, my dear, I only gave her nine... (Pérez Galdós 1952a: 38).

It was from this third category of capital that the complex stipend of Amparo proceeded, generally taking the suitable form of the most worn peseta notes and cuarto coins. [...] 'Don't worry dear. All I've given her is nine reals... (Pérez Galdós 1998: 25).

28 Los aires de grandeza y la cursilería del personaje de Rosalía, esta gran creación galdosiana, ha sido destacada muy frecuentemente (Moreno Hernández 2008: 36). 


\section{EJEMPLO 15:}

La primera versión se muestra moderada al rebajar el nivel de dificultad al cambiar la Pipaón por la señora Pipaón, frase española que ya ha empleado antes, y un tipo de vino menos conocido por el popular sherry entre la población británica. Por su parte, la traductora es mucho más audaz ya que exagera mucho el tratamiento con su her ladyship, que resulta abiertamente humorística en lugar de irónico, como el original (arte en el que era maestro Galdós). Sí conserva, por su parte, la más oscura denominación para sus lectores de manzanilla:

La Pipaón de la Barca, luego que le quitó el abrigo a Alfonsito, y los calzones y los zapatos, para que no destrozara la ropa con su endiablado furor acrobático, volvió a donde estaban su hija y el primo. «¿Quieres tomar alguna cosa, Agustín? ¿Quieres una copita de manzanilla?... (Pérez Galdós 2007: 181).

Señora Pipaón de la Barca, after taking off Alfonsito's overcoat, and his shoes and over-breeches, so that he should not destroy his clothes in his wild acrobatical fury, went over to her daughter and her cousin. "Won't you have something to take, Agustín? Just a little glass of sherry... (Pérez Galdós 1952a: 50).

Her Ladyship, having taken off Alfonsito's overcoat, breeches and shoes, so that his furious acrobatic obsession should not destroy his clothes, returned to her daughter and cousin. 'Would you like anything to eat or drink, Agustín? How about a drop of manzanilla? (Pérez Galdós 1998: 35).

\section{EJEMPLO 16:}

El título de la pieza teatral se tradujo en la primera versión la cual, por otra parte, no ayuda a sus lectores que no tendrían necesariamente que conocer que Pedro Calderón se apellidaba también "de la Barca» (aunque se explique en primeras páginas), con lo que no se comprendería el juego de palabras y gracia de la confusión tan delatora de la vanidosa Pipaón. La segunda versión, por el contrario, es más oscura: no aclara tampoco dicha gracia y deja el título en español:

-Creo que estaremos allí a la mitad del primer acto. Echan Dar tiempo al tiempo. -De Pipaón de la Barca... digo, de Calderón (Pérez Galdós 2007: 189).

"I think we shall get there half-way through the first act. They're are doing Wait for the Moment." "By Pipaón de la Barca... I mean Calderón (Pérez Galdós 1952a: 56).

'I think we'll be there halfway through the first act. They're playing Dar tiempo al tiempo.' 'By Pipaón de la Barca... I mean, but Calderón (Pérez Galdós 1998: 40).

\section{EJEMPLO 17:}

En este fragmento sí que hay unanimidad en la inclusión de la palabra original de escudos, no necesariamente transparente para el lector de lengua inglesa:

Eran billetes del Banco de España. Amparo vio la palabra escudos, ninfas con emblemas industriales y de comercio, muchos numeritos... (Pérez Galdós 2007: 225). 
[...] banknotes of the Bank of Spain. Amparo saw the word ESCUDOS, nymphs bearing emblems of industry and commerce, and long lines of figures... (Pérez Galdós 1952a: 88).

They were notes of the Bank of Spain. Amparo saw the word escudos, nymphs with industrial and commercial emblems, many little numbers (Pérez Galdós 1998: 64).

\section{EJEMPLO 18:}

El muy significativo diminutivo del nombre de Pedro, Periquillo, con tanto valor semántico en el original, se neutraliza en la primera traducción, sin duda por no existir apenas este tipo de diminutivos en inglés. Sin embargo la segunda traducción, como ya hiciera con Amparito en el ejemplo número nueve, asume el riesgo y lo conserva, no sabemos con qué éxito de comprensión, eso sí ayudado por la información entre paréntesis y un adjetivo old también muy connotativo en inglés:

Pues bien, desgraciado Periquillo (voz afectuosa): hablándote como amigo, como sacerdote, como ex-cazador, como extremeño, como lo que gustes, te pregunto: «QQuieres salvarte de la deshonra, de la muerte y de las llamas eternas? (Pérez Galdós 2007: 283). ${ }^{29}$

So, my dear and unhappy Pedro [with affection in his voice], speaking to you as a friend, as a priest, as an ex huntsman, as a man from Extremadura, or how you will, I ask you: 'Do you want to save yourself from dishonour, death and eternal flames?"' (Pérez Galdós 1952a: 142-143).

Now then, poor old Periquillo (affectionate voice); talking to you as a friend, as a priest, as an ex-hunter, as an Extremaduran, as whatever you will, I ask you: do you want to save yourself from dishonour, death and eternal hellfire?' (Pérez Galdós 1998: 108).

\section{EJEMPLO 19:}

Para entender este fragmento de texto es necesario estar familiarizado con la tradición pictórica española y sus grandes maestros. Los dos traductores lo dan por hecho, sin ningún tipo de ayuda. Seguramente esto redujo la comprensión de estos pasajes de sus traducciones y la popularidad de esta obra de Galdós en inglés, pero estos no tienen por qué ser los únicos objetivos:

El escueto y rechupado clérigo, la señora con cara de caoba y vestido negro, tomaron asiento en la sala. El primero parecía haberse escapado de un cuadro del Greco. La segunda estaba emparentada con los Caprichos de Goya (Pérez Galdós 2007: 376).

The lean and parishless priest, and the mahogany-faced lady in black sat down in the sitting-room. He looked as if he had stepped out of an El Greco painting. She seemed in some way related to Goyas "Caprices" (Pérez Galdós 1952a: 238-239).

29 Estos dos personajes, el padre Nones y Pedro Polo (Periquillo) representan una severa crítica de Galdós a la enseñanza religiosa que llevaba a la vida sacerdotal a hombres cuya constitución corporal y sicológica les hacía más aptos para la vida amorosa y familiar (Benítez 1990: 68). Las consecuencias son muy dolorosas, por ejemplo para la protagonista, Amparo-Tormento. 
The lean, wiry cleric, the lady with the mahogany face and the black dress, both took a seat in the parlour. The former looked as though he had escaped from a painting by El Greco. The latter was akin to Goya’s Caprichos (Pérez Galdós 1998: 183).

\subsection{Omisión}

EJEMPLO 20:

En este fragmento los traductores hacen un gran esfuerzo para traducir las variantes de uso del nombre de la protagonista, Amparo. Aunque el esfuerzo resulta meritorio, a los conocedores del texto original les puede parecer que no se han recogido todos los matices del mismo. Resulta curioso comprobar que el primer traductor omite el diminutivo Amparito, con lo que se pierden sus muchas connotaciones en español; por el contrario la traductora asume el riesgo de conservarlo, aunque sin aclaraciones:

Difícil era fijar el escalón social que en la casa de Bringas ocupaba Amparo, la Amparo, Amparito, la señorita Amparo, pues de estas cuatro maneras era nombrada (Pérez Galdós 2007: 163).

It is difficult to assess the social position occupied by Amparo in the Bringas household. Amparo, that girl Amparo, Amparo dear, Señorita Amparo, she was called in all four ways (Pérez Galdós 1952a: 33).

It is difficult to determine the social station held in the Bringas household by Amparo, our Amparo, Amparito, Miss Amparo, for all four of these manners of address were used on her (Pérez Galdós 1998: 21).

\section{EJEMPLO 21:}

Aunque encierros y novilladas no formen parte de su experiencia vital, los lectores británicos seguramente entienden sin dificultad el peligro que puede derivarse de la aparición imprevista de un toro en medio del campo. Sin embargo, al primer traductor le debió parecer una complicación innecesaria añadir que este animal debía proceder de las riberas del río Jarama. La traductora hace lo contrario. No le importa complicar la comprensión del texto de su traducción, no anotada, debe recordarse, con este dato:

[...] y ante estas miradas, sentía ella pavor inmenso, cual si en despoblado se le apareciera un toro jarameńo amenazándola con su horrible cornamenta (Pérez Galdós 2007: 344).

[...] beneath his gaze she felt a dreadful panic, as if a wild bull had suddenly appeared in a lovely place and threatened her with his horns (Pérez Galdós 1952a: 202-203).

$[\ldots]$ and under that gaze she felt an immense dread, just as if a fierce Jarama bull had loomed up as she stood in some deserted spot threatening her with its terrible horns (Pérez Galdós 1998: 156). 


\subsection{Adición}

EJEMPLO 22:

En el original, entredós es un armario de poca altura que suele colocarse entre dos balcones de una misma pared, de ahí su nombre, pero también puede referirse a una tira bordada o de encaje cosida entre dos telas. Por el contexto y por la existencia de un jarrón que hay que colocar sobre algún sitio o mueble, aquí parece, con claridad, que se trata de la primera acepción. Por ello, no parece muy oportuno el doily (mantelito, pañito, estera ornamental) que se empleó en la primera traducción, aunque podría haber una metonimia del mueble por el paño que se coloca sobre este. Sí nos parece más correcto el chiffonier, aunque no se trate exactamente del mismo mueble (cómoda alta y estrecha con cajones), de la segunda traducción. Además se conserva la cursiva del entredós original, que denotaba una cierta extrańeza presuntuosa y seudoelegante, unida a un término en francés, lo que añade más matices de distinción chic parisina:

Si hubiera tenido tres cuerpos, no le bastaran para atender a todo: «Felipe, coge con mucho cuidado el florero y ponlo en el entredós» (Pérez Galdós 2007: 157).

If he had had three bodies they would not have been enough to deal with everything: "Felipe, take that flower-vase very carefully and put it on the doily (Pérez Galdós 1952a: 28).

Had he had three bodies, they would not have sufficed to see to everything: 'Felipe, take that base very carefully and put it on the chiffonier (Pérez Galdós 1998: 17-18).

\section{EJEMPLO 23:}

De nuevo el primer traductor reproduce los nombres españoles en su totalidad, con independencia de la claridad de comprensión, en este caso la Sala Gasparini, mientras la segunda ayuda al lector: Gasparini Room, que además -añade por su cuenta- que está en el Palacio, se entiende que el Real:

¿No te parece que estás viendo la sala Gasparini? (Pérez Galdós 2007: 158).

Can't you imagine you're looking at the Sala Gasparini? (Pérez Galdós 1952a: 29).

You could almost believe you were looking at the Gasparini Room at the Palace, don't you think? (Pérez Galdós 1998: 18).

\section{EJEMPLO 24:}

En estas líneas resulta muy llamativo que la segunda traductora añade una expresión idiomática, «every one must cut their coat according to their cloth», donde el original era muy literal y con un equivalente muy sencillo en inglés. La libertad creativa, sin duda, del traductor:

«Déjala que trabaje — contestaba Rosalía—. ¡Si al fin ha de vivir de sus obras! [...] Están muy consentidas estas muchachas... Es preciso, Bringas, que cada cual viva según sus circunstancias» (Pérez Galdós 2007: 167). 
"Let her work," Rosalía would answer. "After all, she has to earn her living [...] Those girls are very spoilt... It's only right, Bringas, that everybody should live according to their circumstances" (Pérez Galdós 1952a: 36).

'Let her work', Rosalía would remark. 'So what? She has to live from her work after all. [...] These girls have got into very bad ways... Everyone, Bringas, must cut their coat according to their cloth' (Pérez Galdós 1998: 23).

\section{EJEMPLO 25:}

La segunda traductora vuelve a ayudar a los lectores británicos especificando que el Príncipe es un teatro, algo que no hace el primero. Además conserva la tilde de la palabra que nos ocupa, algo irrelevante en inglés, pero que si ańade cierta aura de extrañeza que puede atraer al lector:

Me parece que es él quien llama. Hoy quedó en traerme billetes para el Príncipe... (Pérez Galdós 2007: 172).

I think that's him at the door. He promised to bring me tickets today for the Principe... (Pérez Galdós 1952a: 40).

I think that's him ringing... He arranged to bring me tickets for the Príncipe Theatre today... (Pérez Galdós 1998: 27).

EJEMPLO 26:

El primer traductor presenta una cierta debilidad que la segunda evita. El Banco de Madrid no existe, pues se refiere a la banca o sector bancario. Por otra parte resulta muy llamativo cómo en 1998 la traductora pluraliza el apellido español: Bringases, algo a lo que no se atreve el de 1952:

Hacía vida retirada, y no sostenía relaciones constantes más que con sus primos los Bringas y con dos o tres amigos del comercio y banca de Madrid, a quienes conoceremos más adelante (Pérez Galdós 2007: 174).

He led a retired life, and kept up constant relations only with his Bringas cousins and with two or three friends in business or in the Bank of Madrid, whom we shall meet later (Pérez Galdós 1952a: 43).

He lived an exceedingly retiring life, and only maintained constant contact with his cousins the Bringases and two or three friends in the world of Madrid banking and business, whom we shall meet presently (Pérez Galdós 1998: 29).

EJEMPLO 27:

De nuevo se demuestra que muy a menudo, aunque no siempre como ya sabemos, la traductora de 1998 ayuda a sus lectores en mayor medida y les indica de manera muy explícita que la Castellana es un paseo y el Retiro un parque, con la palabra inglesa en este segundo caso (park), algo que era innecesario en el original:

Los tres daban la vuelta de la Castellana o del Retiro y regresaban a sus respectivos domicilios al punto de las seis o seis y media (Pérez Galdós 2007: 183-184).

The three of them then took a stroll down the Castellana or the Retiro, and returned to their respective homes at six or six-thirty precisely (Pérez Galdós 1952a: 52). 
The three of them would take a stroll down the Paseo de la Castellana or in the Retiro Park and then return directly to their respectives abodes at six or half past six (Pérez Galdós 1998: 36).

\section{EJEMPLO 28:}

La añeja palabra española de tamañito se tradujo en la primera ocasión un sencillo as a child, aceptable pero sin la gracia castiza y afecto del original. La traductora de la segunda versión, por el contrario, vuelve a mostrar su afición a los modismos, «knee-high to a grasshopper», aunque no aparezcan en el original, algo que ya hemos comentado y conocido y que le caracteriza:

Había sido Nones amigo de su padre; a Pedro le conoció tamañito, y se permitía tutearle y echarle ásperas reprimendas, que el desgraciado ex-capellán oía con respeto (Pérez Galdós 2007: 277).

Nones had been a friend of his father's; he had known Pedro as a child; and he went so far as to address him familiarly and to deal him harsh reprimands, to which the unfortunate ex-chaplain listened with respect (Pérez Galdós 1952a: 138).

Nones had been a friend of his father; Pedro he had known since he was knee-high to a grasshopper and he allowed himself to use the familiar form of address to him and reprimand him harshly, which the unfortunate exchaplain would respectfully listen to (Pérez Galdós 1998: 103).

\subsection{Compensación}

\section{EJEMPLO 29:}

El traductor de 1952 ve necesario añadir una nota explicativa al vocablo español que escribe en cursiva. Solo hay dos notas en todo el volumen. La traductora de finales del siglo XX no considera necesario añadir aclaraciones. Tal vez una novela como Tormento, tan marcada por el tiempo y el espacio, requeriría una edición anotada en inglés y en otras lenguas, para llegar a un sector más amplio del público:

[...] al cual se ha de aplicar pronto una voz puramente espańola, como el vocablo pronunciamiento, que está dando la vuelta al mundo y anda ya por los antípodas (Pérez Galdós 2007: 194-195).

[...] for which some purely Spanish word should promptly be coined, like the word pronunciamiento, ${ }^{1}$ which is making a tour of the world and has already reached the antipodes (Pérez Galdós 1952a: 60). ${ }^{1}$ Military coup. [...] which will soon surely have to be given a purely Spanish label, like the word pronunciamiento, which is going round the world and has already found its way to the antipodes (Pérez Galdós 1998: 42).

\section{EJEMPLO 30:}

En esta ocasión, tal vez sea necesario reconocer que ninguno de los dos traductores pudo reproducir la gracia, la locuacidad, el atrevimiento y los dobles sentidos de doña Rosalía, la de Bringas. Seguramente, aunque haya esfuerzo, era imposible. De nuevo, además, otro modismo añadido por la traductora de 1998 (butter/melt/ 
mouth), aunque en esta ocasión puede pensarse que compensa la pérdida parcial del anterior no traducido, "la matan callando»:

Dijeron que eres de los que las matan callando... ¡Si tendrás tú algún trapicheo por ahí! (Pérez Galdós 2007: 287). ${ }^{30}$

They said that you were one of those men who kill by their silence. If only you had some parlour trick or other somehow! (Pérez Galdós 1952a: 147).

It was said that you were waking up, and that you only as though butter wouldn't melt in your mouth. If you're up to something out there... (Pérez Galdós 1998: 110-111).

\subsection{Ilustración}

Solo el primer traductor hace uso de este recurso por medio de los grabados que ya han sido objeto de comentario en estas páginas.

\section{Conclusiones}

En primer lugar, una vez estudiada la selección de ejemplos, creemos que puede afirmarse que los dos traductores realizaron una labor muy meritoria. Si se examinan los textos traducidos de la novela Tormento (1884), Torment (1952) e Inferno (1998), se deduce con facilidad que ambos traductores conocían bien su oficio, rebosaban talento y se empañaron de los intríngulis y características más exigentes de la obra de Galdós en general y de esta obra en particular. Las dos traducciones siguen siendo válidas, poseen rasgos muy positivos y convenientemente anotadas podrían alcanzar a un público amplio de lectores en lengua inglesa. Esto es algo fundamental, ya que el prestigio de Galdós, menor al de otros novelistas de su talla y época, en lenguas y culturas extranjeras, lo que es tanto un lamento como un clamor por parte de la crítica, se debió, en gran medida, y debe todavía, a la existencia limitada de traducciones y al éxito relativo de estas. Sigue siendo una tarea pendiente, tanto realizar nuevas traducciones, sobre todo de textos nunca o poco traducidos, como estudiar y reeditar las traducciones existentes, lo cual puede considerarse un objetivo propio de este capítulo.

Hay que reconocer, igualmente, que traducir a Galdós, tan español y apegado a lo local, sobre todo cuando nos adentramos en sus así llamadas "novelas contemporáneas», no es tarea sencilla si nos proponemos traducirlos a otras lenguas y que sea entendido plenamente en otras culturas, aunque queda aquí demostrado, con las dos traducciones de Tormento que nos han ocupado, que no es imposible lograrlo con gran éxito.

En tercer lugar, si nos centramos en los elementos de comparación (tertium comparationis) que hemos utilizado, según se adujo en su momento, para seleccionar los ejemplos del original y sus dos traducciones inglesas, y que habían sido sugeridos tanto por J. M. Cohen, el primer traductor, como por Abigail Lee Six, la segunda traductora, podemos afirmar todo lo siguiente: a) los dos traductores se esfuerzan mucho en reproducir

29 Cabe señalar, apoyados en este ejemplo, el dominio del arte de la palabra y la riqueza coloquial con que Galdós define a sus personajes de todas las clases sociales de la realidad madrileña de su época, pequeño universo que simbolizaba toda España (Román 1993: 11-12) (Rodríguez Marín 1996: 1015). 
los largos y variados nombres de persona españoles, a menudo grandilocuentes, y todos sus matices de respeto o ironía, clase social, estado civil, títulos y tratamientos asociados, etc.; b) lo mismo se aplica a los nombres de lugar: callejero, instituciones (Palacio Real, Iglesias, etc.), lugares de recreo (parques, teatros), platos típicos y otras costumbres, monedas, mobiliario; c) no se rehúye el reto de las palabras más típicas de la manera de vida y maneras de ser espańolas: merienda, manzanilla, pollo (joven presumido), toros del Jarama, mantecada (de Astorga), sea cual sea el éxito de las equivalencias elegidas; d) en general, se evita enfrentarse a las dificultades casi insalvables, mientras no se demuestre lo contrario, de traducir al inglés los diminutivos españoles o el juego entre el tú y el usted, realidades lingüísticas que el inglés no posee; y e) se pueden encontrar verdaderos logros en la reproducción de la ironía galdosiana, aunque la maestría del canario al respecto sea algo inalcanzable para la inmensa mayoría de los mortales.

Si nos fijamos con mayor detalle en los puntos propuesstos de Mona Baker y Kruger-Wallmach-Sanderson, los cuales hemos utilizado tanto para organizar como comentar los ejemplos seleccionados, podemos afirmar lo siguiente de cada uno de ellos:

Sustitución. En los ejemplos seleccionados se demuestra claramente que se trata de un recurso básico, con traducciones directas más o menos afortunadas, sustitutos culturales o funcionales, palabras más neutras o generales y todo tipo de juegos con las expresiones idiomáticas. Ambos traductores demuestran gran pericia.

Repetición. Sin embargo tal vez sea este el recurso que más brilla en estas traducciones, con gran variedad de nombres propios reproducidos total o parcialmente, así como con la presencia de préstamos con diferentes grados de adaptación. De aquí se deriva todo el sabor típico del original que no se quiere perder en el inglés traducido que caracteriza tanto a Torment como a Inferno.

Omisión. Esta práctica, por el contrario, es esporádica y minoritaria. Los dos traductores realizan todo tipo de esfuerzos para que los elementos formales y de contenido del original se conserven por encima de todo.

Adición. Este recurso tampoco define grandemente estas dos traducciones. Lo que se añade tiene intenciones muy funcionales y busca una mayor claridad en diversos pasajes del texto que pueden resultar confusos.

Compensación. Se presenta en forma de notas a pie de página y de manera muy esporádica. No resulta significativa.

Ilustración. Solo afecta al primer traductor y creemos que se puede definir como todo un acierto.

Por último, para terminar de definir las estrategias generales y perfiles de estos dos traductores, creemos poder afirmar que la característica más atractiva y definitoria de ambos es la búsqueda de un equilibrio entre la comprensión de sus textos traducidos, es decir, que un lector de lengua inglesa, pueda comprender el mundo madrileño decimonónico de Galdós hasta cierta medida; y la reproducción de la extrańeza de aquel mundo en bastante medida para que nadie se lleve a engaño y parezca que estemos le- 
yendo un sucedido del Londres dickensiano del siglo XIX. Es decir, un meritorio equilibrio entre no pasarse y quedarse corto. 


\title{
CAPÍTULO VI
}

Reivindicación y apropiación de un género galdosiano: los Episodios de una guerra interminable de Almudena Grandes

\author{
Toni Dorca \\ Macalester College (Minnesota)
}

\section{CONSIDERACIONES PRELIMINARES}

Almudena Grandes ha reconocido en más de una ocasión la filiación con el género histórico galdosiano de las cuatro novelas que hasta ahora integran los Episodios de una guerra interminable: Inés y la alegría (2010), El lector de Julio Verne (2012), Las tres bodas de Manolita (2014) y Los pacientes del doctor García (2017). ${ }^{1}$ En el epílogo de Inés y la alegría, explica que el marbete "episodios» que figura en el título de la serie obedece a un deseo de enlazar su proyecto con el de Benito Pérez Galdós (Grandes 2014a: 719). Dice que ha abrazado el «espíritu» de los Episodios nacionales y preservado, «en la medida de lo posible», el «modelo formal» (Grandes 2014a: 720) de los mismos. Confiesa incluso que le habría gustado mantener el término «nacional», pero que desistió de ello a causa de la desvirtuación que, a su juicio, ha sufrido el adjetivo por culpa de "Franco y el franquismo» (Grandes 2014a: 720). Aparte de los testimonios personales de Grandes, hay que destacar que sus novelas contienen alusiones concretas a personajes que leen los Episodios nacionales (Grandes 2014a: 179 y 231-232; Grandes 2014c: 380), o bien son dueños de sus Obras completas (Grandes 2014b: 185). Se mencionan igualmente relatos de la primera serie, los cuales inciden en mayor o menor grado en el desarrollo de la acción: El 19 de marzo y el 2 de mayo (Grandes 2014b: 193, 194 y 366), Bailén (Grandes 2017: 125, 157 y 260), Trafalgar (Grandes 2017: 266-268) y La corte de Carlos IV (Grandes 2017: 668). Los Episodios de una guerra interminable son, en fin, un «homenaje» a un escritor de los que "más ha influido en ella», tanto en su etapa de lectora juvenil como, más adelante, de autora (Grandes 2014a: 720).

Junto a estas referencias explícitas, Grandes recurre a otros procedimientos que revelan su afinidad con Galdós, a la par que realzan la comunión ideológica entre ambos novelistas. Puede hablarse, en este sentido, de apropiación de unas técnicas y unos con-

1 La publicación de la quinta entrega, La madre de Frankenstein, está prevista para febrero de 2020. La última se va a llamar Mariano en el Bidasoa. 
tenidos que ella incorpora luego a sus obras. Puesto que en el lenguaje de nuestros días el vocablo «apropiación» suele denotar la explotación, con fines comerciales, de la producción autóctona de una cultura minoritaria a manos de otra hegemónica, ${ }^{2}$ conviene insistir en la veneración que siente la madrileńa por su predecesor, a quien considera un referente artístico, político y moral. Su propuesta, eminentemente literaria, recupera la fórmula galdosiana por considerarla la más idónea a la hora de novelar la historia española del siglo XX. Acogerse a las convenciones de un género establecido le permite, por otro lado, un margen de maniobra mayor del que dispondría en una adaptación. En efecto, el hipertexto resultante de una apropiación no tiene por qué ceñirse a unos acontecimientos previamente narrados, ni depende tampoco de la identificación del hipotexto para su correcta recepción: «the appropriated text or texts are not always as clearly signalled or acknowledged as in the adaptative process» (Sanders 2006: 26). ${ }^{3}$ La trama ficticia de los Episodios de una guerra interminable, al ser fruto de la invención de la autora, funciona autónomamente sin que la legitime un hipotexto anterior en el tiempo. Lo mismo cabe decir de la selección de la materia histórica, centrada en los períodos de la Segunda República, la Guerra Civil y la Dictadura franquista, y posterior, por tanto, al marco decimonónico de los Episodios galdosianos.

Sentadas las bases de lo que se entiende aquí por apropiación, en las páginas siguientes van a examinarse sus varias aplicaciones en los Episodios de una guerra interminable. Los aspectos en los que voy a detenerme son tres: el retrato de los protagonistas masculinos y femeninos; la exposición y reflexiones sobre la historia de España; y la sempiterna confrontación entre liberalismo y absolutismo, reflejo del desencanto ante la coyuntura presente. El análisis se circunscribe a los diez tomos de la segunda serie de los Episodios nacionales, los correspondientes al reinado de Fernando VII: El equipaje del rey José (1875), Memorias de un cortesano de 1815 (1875), La segunda casaca (1876), El Grande Oriente (1876), 7 de julio (1876), Los cien mil hijos de San Luis (1877), El terror de 1824 (1877), Un voluntario realista (1878), Los apostólicos (1879) y Un faccioso más y algunos frailes menos (1879). La elección de dicha serie no se debe tanto a la necesidad de delimitar el enfoque de este trabajo, cuanto al hecho de que su presencia en las narraciones de Grandes ha pasado totalmente desapercibida a los estudiosos. ${ }^{4}$ Me parece además sorprendente -y, desde luego, nada casual- que en ninguno de los episodios de la madrileña se cite el nombre de un solo episodio del ciclo fernandino, aun cuando sus vínculos son innegables. Que Grandes tome para sí unos materiales de manera subrepticia constituye una ingeniosa estrategia de rendir tributo a Galdós que aúna reivindicación y apropiación. En otras palabras, nuestra autora teje una tupida red de conexiones donde confluyen la entusiasta absorción de un género novelístico, la formulación de un nacionalismo de cuño liberal y el guiño a un lector cómplice.

2 El diccionario de la Real Academia Española no recoge todavía el sintagma "apropiación cultural», que sí aparece por doquier en internet.

3 El hipotexto es "the source text of any appropriation or rewriting» (Sanders 2006: 162); el hipertexto, «the appropriative or adaptative text» (Sanders 2006: 162). La terminología procede de Gérard Genette (1982).

4 Bien por el ocultamiento del hipotexto, bien por desconocimiento de la producción histórica de Galdós, bien por ambos factores. 


\section{HÉROES, HEROÍNAS Y VILLANOS}

El éxito comercial de los episodios de Galdós y Grandes tiene mucho que ver con la asimilación de diversas modalidades de literatura popular. La deuda de los Episodios nacionales con el folletín romántico la señaló ya en su día Hans Hinterhäuser (Hinterhäuser 1963: 339-340), y desde entonces ha devenido un lugar común de la crítica. Por parte de Grandes, la frecuente intercalación de escenas de amor acentúa la carga melodramática y sexual de sus novelas, en consonancia con un lector alejado emocionalmente de los sucesos de la Guerra Civil y cuyo horizonte de expectativas lo determinan las tendencias dominantes en el mercado global de la literatura (Sánchez 2012: 194). La madrileña recurre también a los esquemas del relato de aventuras, con referencias a Julio Verne (Grandes 2014b: 99, 112, 128, 130, 187, 191-192, 248, 249 y 278) y a La isla del tesoro de Robert-Louis Stevenson (Grandes 2014b: 289, 334, 365 y 366) en El lector de Julio Verne; o en Los pacientes del doctor García, a la novela de espías y nazis en un contexto internacional. Cada una de estas variedades otorga una importancia capital a la intriga: sorpresas, imprevistos, casualidades, suspense, anagnórisis, dilatación del desenlace, etc. El flirteo con los esquemas de la literatura popular se manifiesta con particular empeño en el trazado de los protagonistas y los antagonistas. Los héroes, heroínas y villanos de los Episodios de una guerra interminable entroncan, de este modo, con las cuatro figuras principales de la segunda serie de los Episodios nacionales: Salvador Monsalud, Genara Baraona, Solita Gil de la Cuadra y Carlos Navarro.

\subsection{Héroes}

En el universo de Grandes, los hombres heterosexuales 5 que acometen insólitas proezas representan un arquetipo de masculinidad fuertemente arraigado en el imaginario colectivo: atractivo físico; dinamismo; iniciativa en la toma de decisiones; valentía no reñida con la caballerosidad; aura de misterio; defensa a ultranza de la causa de la libertad; por último, vehemencia del sentimiento amoroso. Galán en Inés y la alegría, así como Guillermo y Manuel en Los pacientes del doctor García, encarnan mejor que nadie estas cualidades.

Fernando González Muñiz, cuyo alias más conocido es Galán, trabajó como minero antes de huir a Francia y tomar parte en la frustrada invasión del valle de Arán junto con otros guerrilleros. Acepta más adelante misiones de espionaje en España, convirtiendo la clandestinidad en una segunda naturaleza. Cae herido en Madrid, aunque consigue salvarse merced a una combinación de fortuna, ayuda e ingenio. En el plano afectivo, la compañía de su amada lo llena tan por entero que llega a comparar a esta con la España anhelada que quiere recobrar: «mi propia versión de la patria perdida» (Grandes 2014a: 338). El paso del tiempo, la desidia que percibe en sus paisanos, los peligros que arrostra de continuo, las exigencias de la familia y el descontento con el funcionamiento del Partido Comunista, van mermando su activismo. Galán se transforma gradualmente de combatiente en comerciante dedicado a la importación de productos

5 El respeto a la alteridad de género iguala también homosexualidad y heroísmo: Ninot en Inés y la alegría; Francisco Román Carreño, alias la Palmera, en Las tres bodas de Manolita. 
españoles a Francia. El regreso al país natal durante la Transición culmina su acomodo burgués, si bien conserva el orgullo de no haber abdicado jamás de sus creencias: «Yo nunca me arrepentiré de ser comunista» (Grandes 2014a: 715).

Nieto de un republicano librepensador, Guillermo García Medina recibe una educación laica y humanista en la Institución Libre de Enseñanza. Las desavenencias con su novia falangista provocan una dolorosa ruptura entre ambos, de la que Guillermo se recupera gracias a la ayuda médica dispensada a los infiltrados, entre ellos Galán. Su trabajo en una agencia de transportes le procura una coartada para colaborar en la localización de los nazis camuflados en Madrid, amparados por un Gobierno que se niega a entregarlos a la Justicia. Redimido de la culpa que siente por seguir vivo mientras otros amigos suyos han fallecido, Guillermo no olvida su condición de perdedor de una guerra y, por ende, paria de la historia desprovisto de identidad: «la derrota, la más vieja y áspera de mis amantes» (Grandes 2017: 497). La recomposición de su ser tiene lugar por mor de una concatenación de incidentes felices que premian su audacia: el asesinato de un enemigo que amenazaba su confort; el éxito empresarial que le proporcionan, como él mismo admite con cierta aprensión, los mismos nazis a quienes ha traicionado; $y$, sobre todo, el descubrimiento del amor verdadero, que le devuelve la paz consigo mismo.

Manuel Arroyo Benítez se encuadra en el patrón del parvenu, o «Young Man from the Provinces» (Trilling 1950: 61), de la novela realista decimonónica: un joven sin recursos procedente del mundo rural, cuyas excepcionales dotes para el estudio lo aúpan a un cargo de responsabilidad dentro del ejecutivo de la Segunda República. Finalizada la Guerra Civil, Manuel está dispuesto a arriesgar su cómodo exilio por el restablecimiento de la democracia. Se introduce por orden de Juan Negrín en las redes de protección de los criminales nazis en Madrid, donde traba amistad con Guillermo. Su misión consiste en identificar a los miembros de este grupo y denunciarlos a la Asamblea General de las Naciones Unidas. Lamentablemente, el éxito de su cometido no propicia una intervención de la comunidad internacional que provoque la caída de Francisco Franco. La futilidad de su empresa suma a Manuel en una profunda desazón, acrecentada por la vida de impostura que lleva desde hace años: «estaba muy cansado [...] de no tener casa, ni familia, ni futuro» (Grandes 2017: 545-546). En el nadir de su existencia, el encuentro con una mujer tan desdichada como él revierte el fracaso de una juventud desperdiciada en una ambivalente aceptación de su destino.

Detrás de Galán, Guillermo y Manuel se solapa el héroe «problemático» (Beyrie 1987: 221) de la segunda serie de los Episodios nacionales. Monsalud es una construcción híbrida en la que confluyen realidad histórica y cosmología romántica: el juramentado de la era josefina que termina en las filas del liberalismo; el desterrado escindido entre la nostalgia y el aborrecimiento de la patria; el escéptico a lo Larra; el conspirador nato, en la línea de los históricos Juan Van Halen (1788-1864) y Eugenio de Avinareta (17921872); la víctima de un sino malhadado que recuerda a don Álvaro, del drama homónimo del duque de Rivas; el enamorado perpetuo cuyas relaciones acaban mal; y el reformador utópico de la nación. Las contradicciones de su carácter no frenan una evolución positiva que rebasa con mucho el esquematismo de sus antecesores Lázaro ( $\mathrm{La}$ Fontana de Oro), Martín Muriel (El audaz) y Gabriel Araceli (primera serie de los Episodios). Nos las habemos, en suma, con un individuo conflictivo y fascinante a partes iguales. 
Las similitudes entre el liberal romántico y los paladines del republicanismo son muy significativas por cuanto perfilan la etopeya del héroe de Galdós y Grandes: el compromiso político con la soberanía de la nación, que le ha sido arrebatada ilegítimamente; el desarraigo espiritual, acentuado por la movilidad constante dentro y fuera del territorio español; la exposición al peligro y la milagrosa supervivencia; el componente emocional como motor de una frenética actividad; y la sublimación de la derrota en el matrimonio. El asentamiento en la dorada medianía, con la estabilidad que suponen la vuelta del exilio y la reinserción social, deja en ellos una sensación agridulce. Es patente que han superado un sinnúmero de contratiempos, pero no lo es menos que la tiranía que querían derribar siguió campando a sus anchas hasta la muerte de los autócratas que la lideraban. Al rememorar sus andanzas, Guillermo y Manuel se autodefinen con unas palabras que ponen en entredicho la eficacia de tanto sacrificio: "pardillos» o, en la jerga juvenil, "pringados» (Grandes 2017: 739). Estos calificativos pueden extenderse al fundador de la especie, Monsalud, un prototipo de revolucionario que se traslada sin solución de continuidad a los opositores al régimen franquista. A todos ellos les cuadra el estribillo que el narrador extradiegético dedica a Manuel, indicio de la paradoja que anida en el interior de este: «siempre había tenido muy mala y mucha suerte» (Grandes 2017: 98).

\subsection{Heroínas}

La mayoría de las protagonistas (Inés Ruiz Maldonado en Inés y la alegría y Manolita Perales en Las tres bodas de Manolita) y secundarias de lujo (Adela en Inés y la alegría; las Rubias, Elena y Pastora en El lector de Julio Verne; Eladia y la madre Carmen en Las tres bodas de Manolita; Meg, María Aránzazu, Rita y Simona en Los pacientes del doctor García) se adhieren a la lucha contra la Dictadura franquista a causa de sus convicciones republicanas, o cuando menos adoptan posturas progresistas con el paso de los años. Rechazan sin ambages el modelo de mujer pregonado desde la Sección Femenina de Falange Espańola, dado que les impide ejercer otra profesión que no sea la de ama de casa. ${ }^{6}$ No es inusual que exhiban su fortaleza mental con demostraciones de arrojo que se equiparan con las de sus colegas masculinos. Suelen sufrir el acoso o el asalto de algún agente de la España vencedora, sin que el castigo que se les inflige impunemente haga flaquear su rebeldía ante la autoridad. A diferencia de la pacatería de la época, practican una sexualidad libre de prejuicios que se cifra en el disfrute del cuerpo. Creen, no obstante, en el poder omnímodo del amor con un solo hombre, del que esperan que corresponda a su pasión con idéntica intensidad. La solidaridad con otras mujeres que se hallan en su situación las instala en una "comunidad femenina» (Calderón Puerta 2017: 15) basada en la cooperación y el apoyo mutuo. Su autoestima crece al compartir un espacio propio: el restaurante que regentan Inés y sus amigas en Toulouse; el cortijo que habitan las Rubias y Elena en una especie de matriarcado; la cola en las afueras de la cárcel, donde Manolita y otras mujeres esperan su turno para visitar a los presidiarios. Aunque no les queda más remedio que resignarse a la perduración de la Dictadura, la crianza de los hijos o el cuidado de los parientes las compensan de los reveses de la historia. Son,

6 En su papel de «ejemplares Penélopes», las mujeres comme il faut estaban «condenadas a coser, a callar y a esperar» (Martín Gaite 2007: 72). 
en general, más prácticas y vitalistas que sus parejas, más resilientes, y se muestran también más alegres de haber sobrevivido a tantas penalidades.

Ninguno de los personajes femeninos de la segunda serie de los Episodios nacionales conjuga independencia de criterio, conocimiento de la realidad nacional, altruismo y apego a un amante como los de las novelas de Grandes. Las dos protagonistas, Solita Gil de la Cuadra y Genara Baraona, representan, de hecho, uno de los polos de la femineidad según los concibe Galdós a la altura de 1875: el ángel del hogar (Solita) y la aventurera (Genara). Late dentro de ellas una admiración mutua que se confunde con la envidia, lo que no favorece precisamente la armonía entre dos rivales que pretenden ambas a Monsalud. Paradójicamente, el perfil antitético de cada una facilita la apropiación parcial de sus rasgos más sobresalientes. Grandes combina, pues, las aptitudes de una y otra a fin de delinear a un colectivo que participa en la acción directa (Genara) sin renunciar por ello a los placeres de la domesticidad (Solita).

Como indicó en su día Rubén Benítez (Benítez 1985: 310), la publicación de Pepita Jiménez en 1874 indicó a Galdós el rumbo a seguir en cuanto a la caracterización de Genara: inteligencia superior, emancipación económico-familiar y «libertad sexual» (Benítez 1985: 332). El descubrimiento de las posibilidades artísticas de este tipo de mujer comporta, por tanto, un «enrichissement soudain» (Beyrie 1980: 222) del universo galdosiano, falto hasta entonces de hembras con autonomía suficiente para escapar del dominio masculino. Por si lo anterior no bastara, Genara posee una dimensión política de la que Pepita Jiménez carece. Su labor de espía al servicio del rey le da la oportunidad de ejercitar sus extraordinarias facultades de mando, moviéndose con total desparpajo por la geografía espańola y francesa. Al percatarse de la vanidad y la venalidad de quienes detentan el poder, se convierte en «una conciencia crítica» (Benítez 1985: 322) que desenmascara los vicios de la Espańa fernandina. Su gradual acercamiento a los seguidores de la reina Regente, María Cristina, corona asimismo un viraje que la lleva del absolutismo más recalcitrante al liberalismo. Por desgracia, su enrevesada sicología limita sus contribuciones al bienestar del prójimo, o incluso -dado su talento- de la nación. El malogramiento del affaire con Monsalud inclina su temperamento hacia los aspectos menos agradables de su persona, la altanería y el egoísmo, con la consiguiente disminución de su aura de excepcionalidad.

El caso de Solita es totalmente diferente. Ni que decir tiene que la sumisión a los dictados del varón, el recato en materia sexual y su alejamiento de la vida pública están en las antípodas de las preferencias de Grandes. Se atisba en ella, sin embargo, una cualidad esencial que los personajes femeninos de la madrileńa retoman: el don de llenar con su mera presencia el vacío existencial de la persona que aman. Solo las prendas morales de Solita — caridad, lealtad, fe, bondad, entre otras— ${ }^{7}$ pueden mitigar las penas del conspirador amargado y prematuramente envejecido en que ha devenido Monsalud después de dos décadas de dar tumbos sin ton ni son. El influjo benefactor de la mujer que alivia la congoja del amante desengañado, o bien espolea su voluntad, reaparece en los episodios de Grandes: Inés-Galán, en Inés y la alegría; Maribel-Nino, en El lector de Julio Verne; Eladia-Antonio y Manolita-Silverio, en Las tres bodas de Manolita; Rita-Guillermo y Simona-Manuel, en Los pacientes del doctor García.

7 Montesinos 1968: 154; Navascués 1987: 506; George 2005: 53. 
En un plano alegórico, las virtudes de Solita trascienden el reducto doméstico para incidir en la configuración de la sociedad posfernandina. La que ha de ser esposa de Monsalud hace algo más que redimir al agitador hastiado del mundo, puesto que simboliza el ideal político del liberalismo moderado que resurge en la Regencia de María Cristina y se consolida posteriormente con el doctrinarismo isabelino. La tolerancia que muestra con el prójimo, así como el equilibrio que rige su conducta, sugieren la necesidad de cimentar el progreso de la nación en el respeto mutuo y el mantenimiento del orden. La condición de ciudadana ejemplar es extrapolable a los personajes con los que Grandes congenia, adalides de la igualdad de derechos en que estriba, a juicio de la escritora, la verdadera españolidad. Mientras que la conformidad de Solita anuncia la posibilidad de una reconciliación nacional en el futuro, Inés y compañía proclaman un sistema alternativo de convivencia que rompe con el statu quo: desde el «heroísmo cotidiano y nunca reconocido» (Grandes 2014b: 412) de las que criaron solas a sus hijos, a «la resistencia» (Grandes 2014c: 750) de las que se enfrentaron cara a cara con los adláteres del franquismo.

\subsection{Villanos}

Casi todos los personajes que desempeñan la función de villanos en los Episodios de una guerra interminable simpatizan con los totalitarismos de extrema derecha y tienen una propensión sádica a la violencia. Figuran en esta lista el hermano de Inés, Ricardo, cuya juvenil militancia en el fascismo adquiere enseguida tonos belicistas; el comandante, luego teniente coronel, Alfonso Garrido, militar «de odiosa arrogancia» (Grandes 2014a: 200) que somete a Inés y a Eladia a todo tipo de vejaciones sexuales, hasta que la segunda lo mata «a quemarropa» (Grandes 2017c: 594); Michelín, teniente de la Guardia Civil en la casa cuartel de Fuensanta de Martos, que ordena torturar a los detenidos y solo piensa en ganarse un «ascenso» (Grandes 2014b: 357); Roberto el Orejas, el «traidor» (Grandes 2014c: 266) que delata a sus compinches republicanos y hace una brillante carrera en la Brigada Político Social ${ }^{8}$ Clara Stauffer ${ }^{9}$ y los nazis que se han refugiado en España y Argentina, reacios a abandonar sus creencias y todavía peligrosos por la capacidad operativa de que disponen; Renato Bley, el marido que maltrata a Simona y la tiene prácticamente secuestrada en una casa de campo.

Capítulo aparte merece Adrián Gallardo Ortega, a quien Grandes otorga una relevancia comparable a las de Guillermo y Manuel: «Mi historia es la historia de tres impostores» (Grandes 2017: 20). Importa consignar primeramente que su lugar de origen, La Puebla de Arganzón, es el mismo donde se criaron Salvador, Genara y Carlos. El abuelo de Adrián se llamaba Carlos Garrote, descendiente de los caciques que se mencionan en la segunda serie de los Episodios nacionales: Fernando (padre) y Carlos (hijo)

8 Aunque Grandes lo trata como un personaje literario que interviene en la historia, el Orejas es el seudónimo ficticio de Roberto Conesa Escudero (1917-1994), «el torturador, y maestro de torturadores, más célebre de la Dictadura» (Grandes 2014c: 751). La autora mezcla datos reales de su biografía con otros de su propia invención.

9 Otro personaje histórico (1904-1984) que Grandes inserta en la acción novelesca sin tergiversar los hechos más notorios de su vida. 
Navarro, alias Garrote, muy bienquistos en la comarca por la reciedumbre de su carácter y la solidez de sus principios absolutistas. El orgullo de pertenecer a una alcurnia ilustre, que Carlos Garrote ha inculcado en Adrián, ha de condicionar sobremanera la identidad de este. Quien se considera el «postrero ejemplar de una célebre estirpe de guerreros» (Grandes 2017: 165), no puede menos que alistarse en la milicia falangista «al grito de Dios, Patria y Rey» (Grandes 2017: 164), como otros vástagos de familias «de tradición carlista» (Grandes 2017: 132). Tras la victoria de los suyos en la Guerra Civil, el nieto quiere continuar emulando las hazañas de los Garrote y "honrar la memoria» (Grandes 2017: 231) del abuelo que acaba de fallecer. Su enrolamiento en la División Azul, a la caza y captura de comunistas, significa para él otra oportunidad de hacerse digno de un linaje cuya aversión al liberalismo raya en la locura. Poco puede imaginar entonces que los horrores que contempla en el frente de Leningrado lo insensibilizarán ante la matanza de prisioneros judíos en que tomará parte poco después: «Comprendió que ya nunca sería otra cosa que un asesino y esa idea no le extrañó, no le asustó, no le repugnó» (Grandes 2017: 301). En 1945, a punto de producirse la caída de Berlín, Adrián se ve a sí mismo como un superviviente de una contienda perdida que ni siquiera le procura el consuelo de haber perseguido un objetivo noble, como sí ocurre con Guillermo y Manuel. A la negación de la épica de la guerra se suma una truncada relación amorosa que lo devuelve más solo que nunca a Madrid, donde perece a manos de Guillermo cuando intenta chantajearlo.

La vinculación familiar, emocional y política de Adrián con los Garrote decimonónicos se manifiesta en los paralelismos que definen la trayectoria vital de uno y otros. Fernando y Carlos combaten a los franceses en la guerrilla, antes de aliarse con los prosélitos del Antiguo Régimen a la vuelta de Fernando VII. Muerto el progenitor, Carlos va recrudeciendo su extremismo al abrazar sucesivamente las facciones realista y apostólica. La última fase de su evolución viene marcada por el paso a las filas del pretendiente Carlos María de Isidro, consumada ya la ruptura con un monarca al que acusa de tibieza. Fiel a su natural guerrero, Carlos vuelve a empuñar las armas por la religión católica para evitar que España emprenda la, para él, perniciosa apertura a formas de gobierno más democráticas. Vemos, pues, que el carlismo transmitido de generación a generación hasta bien entrada la centuria pasada -indicio de su «larga pervivencia en la España contemporánea» (Canal 2004: 25)-, determina el destino de los dos villanos por excelencia de los episodios de Galdós y Grandes. No es casual al respecto que ambos provengan de La Puebla de Arganzón, villa sita en la provincia de Burgos donde en 1875, al comienzo de la escritura de la segunda serie galdosiana, el general Tello logró una importante victoria sobre las huestes de Carlos VII (Dendle 1986: 86). El hundimiento del fascismo ítalo-germano en la Segunda Guerra Mundial engarza con las abortadas tentativas del carlismo, manchando el historial militar de Carlos y Adrián con una humillante derrota.

Más allá de las contingencias de la historia, los dos personajes comparten una atormentada sicología fruto de la idolatría por una figura patriarcal a la que quieren imitar sin conseguirlo jamás del todo. Son, en el fondo, víctimas de unas costumbres rancias que han alimentado su intolerancia en detrimento de otros sentimientos enriquecedores como el amor o la generosidad. La reiteración con que el abuelo exhorta a Adrián a acordarse siempre de sus orígenes — «tú eres un Garrote» (Grandes 2017: 163)— la debió 
de escuchar muchas veces Carlos de labios de su padre Fernando. El desajuste emocional que sufren les priva también de la presencia de una mujer que, tras la etapa inicial de enamoramiento, satisfaga sus anhelos más íntimos. Aunque ninguno lo reconoce, la intransigencia (Carlos) y la indiferencia (Adrián) que muestran en el trato diario los hace aborrecibles a los ojos de sus respectivas consortes, Genara y Agneta. La disolución de su matrimonio agudiza más si cabe la degradación física y mental de los antagonistas: Carlos, agravada su enfermedad por el desequilibrio crónico de su ser, pierde el juicio y expira sin pedir perdón, ni concederlo, a su hermanastro Salvador por las múltiples injurias que le ha infligido; y en cuanto a Adrián, la traumática experiencia en la División Azul aniquila su afectividad y lo transforma en un desarraigado que no tiene patria, ni religión, ni parientes ni amigos. Dada la ideología liberal-democrática que permea los episodios de Galdós y Grandes, nada tiene de extraño que las peripecias de dos sectarios del absolutismo y el fascismo terminen en tragedia. Deshumanización, locura y muerte conforman así la imparable degeneración de quienes integran el brazo armado del pensamiento reaccionario espańol.

\section{LA APROPIACIÓN DE LA HISTORIA}

La apropiación de sucesos y personalidades verídicos es habitual en la novela histórica (Sanders 2006: 138), si bien Grandes tiene claro el estatus de Inés y la alegría y, por extensión, de la serie entera: «es, de principio a fin, una novela, y por tanto, en ningún caso un libro de historia» (Grandes 2014a: 723). Se observa igualmente en todos los relatos una hábil «superposición» (Castañeda Hernández 2011: 149) o «integración» (Basanta 2011: 152) de lo personal en lo colectivo, en virtud de las cuales las vicisitudes de los personajes alteran la marcha de la historia y viceversa.

No obstante la índole literaria de su empresa, Grandes se arroga las funciones propias de un historiador liberal en la línea de Galdós. La autora retrotrae el nacimiento de la nación moderna a aquellos hitos de finales del siglo XVIII y comienzos del XIX que el franquismo impugnará por antiespañoles, cuando en verdad sus artífices fueron «los más patriotas de todos» (Grandes 2014b: 197): la Revolución francesa, Jovellanos, la guerra de la Independencia, los afrancesados, las Cortes de Cádiz o la Constitución de 1812 (Grandes 2014b:195). En consonancia con el didacticismo consustancial al género de los episodios (Hinterhäuser 1963: 132; Dendle 1986: 128; Rodgers 1988: 35), hay un empeño en aleccionar a sus compatriotas sobre el curso de la historia de España, enlazando el pasado reciente con el presente de la escritura. La experimentación con el tiempo narrativo se revela, en este sentido, fundamental. Aun cuando la historia se ordena cronológicamente, la profusión de analepsis y prolepsis genera una «yuxtaposición de secuencias» (Rivas 2012: 81) que encadena épocas diferentes. La mutación temporal hace que el lector experimente dos instantes alejados como si en efecto hubieran transcurrido simultáneamente, de lo que resulta una presentación cíclica de la historia.

Esta «visión totalizadora» (Acín 2010: 82) exige el empleo de una diversidad de fuentes que refrenden la perspectiva de la autora. Las más numerosas son de largo las históricas, con un listado exhaustivo de la bibliografía consultada acerca de los acontecimientos y personas que se recrean: la invasión del valle de Arán (Grandes 2014a: 726-728); el Trienio del Terror (1947-1949) en la Sierra Sur de Jaén (Grandes 2014b: 409, 410, 411 
y 415); el cura Porlier y el Patronato de Redención de Penas (Grandes 2014c: 750-751); Conesa (Grandes 2014c: 751-752); Heriberto Quińones, primer secretario general del PCE clandestino (Grandes 2014c: 753 y 755); la fábrica de armamentos de los Nuevos Ministerios (Grandes 2014c: 755); el Valle de los Caídos en Cuelgamuros (Grandes 2014c: 757); los nazis en la Argentina de Juan Domingo Perón (Grandes 2017: 744745) y la España de Franco (Grandes 2017: 746-747); Negrín y Jesús Monzón (Grandes 2017: 751); la División Azul (Grandes 2017: 751); las actividades de la diplomacia republicana (Grandes 2017: 752); finalmente, Clara Stauffer (Grandes 2017: 750). Los testimonios orales de los amigos de la autora no pueden tampoco soslayarse: el poeta Ángel González la surte de noticias relativas a Nicolás Franco, padre del dictador (Grandes 2014a: 728); las correrías del guerrillero Cencerro en la Sierra se las cuenta en primera instancia Cristino Pérez Meléndez (Grandes 2014b: 406), bien aliñadas con los pormenores de algunos vecinos de Fuensanta de Martos (Grandes 2014b: 408), pero la información más valiosa proviene de la nieta de Cencerro, Esther Estremera Villén (Grandes 2014b: 414-415); la autora conoce en 2008 a Isabel Perales, quien le refiere sus padecimientos en un colegio de monjas (Grandes 2014c: 748-749) y la exhorta a divulgar su historia (Grandes 2014c: 750); Jesús del Cerro García y Bernardo Fuster suplen las carencias de Grandes en lo tocante a la responsabilidad de la Iglesia española en el ocultamiento de criminales de guerra alemanes (Grandes 2017: 749). En cuanto a las fuentes literarias, al modelo formal de El laberinto mágico de Max Aub (Grandes 2014a: 720) debe agregarse la novela $E l$ fin de la esperanza de Juan Hermanos, seudónimo de Marcelino Saporta (Grandes 2017: 384-385), denominación que se incluye en el subtítulo de la cuarta entrega ${ }^{10}$ para reflejar el estado de ánimo de Manuel ante la pasividad de las potencias occidentales. Cabe citar, por último, los intertextos gráficos y cinematográficos: la portada de Paris Match del 26 de enero de 1939, donde se ve a una campesina amamantando a su hijo en la cuneta de una carretera francesa, camino del exilio (Grandes 2014a: 139); la película La hija de Juan Simón, cuya protagonista anticipa la valentía y pundonor femeninos de Eladia (Grandes 2014c: 759); Notorious de Alfred Hitchcock, referente implícito de la trama nazi en Argentina (Grandes 2017: 370); y unas fotografías de Clara Stauffer (Grandes 2017: 745).

Toda esta ingente tarea de documentación permite ofrecer luego a Grandes, en el proceso de la escritura, su interpretación de unas gestas sobre las que no existe «una versión oficial» (Grandes 2014a: 723). Una estrategia de que se sirve para enjuiciar el pasado consiste en la disposición de historia y ficción «en bloques separados» (Acín 2010: 84), en lugar de unirlas en una sola narración como hace Galdós. Nuestra autora se acoge aquí a la "docufiction» (Winter 2012), en la convicción de que sus episodios ganan en autenticidad —e, indirectamente, en calidad — cuanto más y mejor imitan el discurso histórico. ${ }^{11}$ El narrador de Inés y la alegría, que se identifica con Grandes (Grandes 2014a: 723), pondera los aciertos y los errores de los líderes del Partido Comunista: Monzón

10 El fin de la esperanza y la red de evasión de criminales de guerra y jerarcas nazis dirigida por Clara Stauffer, Madrid-Buenos Aires, 1945-1955.

11 La fórmula no ha convencido demasiado a la crítica: «la voz de la autora resulta inoportuna, produciendo una lectura que se mueve de manera incongruente» (Caistor 2010); «La parte histórica se acerca más al ensayo, incluso en ocasiones demasiado» (Díaz Pérez 2010: 27). 
(Grandes 2014a: 683, 688), Carmen de Pedro (Grandes 2014a: 682) y Dolores Ibárruri, la Pasionaria (Grandes 2014a: 689). Por su parte, Inés y Galán relatan en los capítulos restantes sus actividades en Toulouse y el posterior retorno a España. El desdoblamiento en dos narradores, uno extradiegético y el otro intradiegético, se justifica en opinión de la autora por el escaso conocimiento que existe acerca de la Operación Reconquista de España. ${ }^{12}$ Como no sería creíble que dos guerrilleros como Galán e Inés estuvieran al tanto de los tejemanejes de sus dirigentes, ni se puede esperar que el lector coetáneo lo esté de «la coyuntura histórica y la trama política» (Grandes 2014a: 723) previas a la invasión del valle de Arán, la madrileña se encarga de desentrañar el complejo entramado. Análogo recurso se utiliza en los capítulos «Un principio: El caso de las máquinas inútiles» (Grandes 2014c: 17-25) y «Un final: La trayectoria de un ejemplar servidor del Estado» (Grandes 2014c: 715-727) de Las tres bodas de Manolita, donde se esboza una biografía de Conesa sustentada únicamente en datos reales. En Los pacientes del doctor García se vuelve al esquema de Inés y la alegría: un narrador-historiador-autor que escribe en presente histórico los capítulos 1, 3, 5, 14, 16, 22, 23, 27, 29, 38, 40 y 43; un narrador extradiegético que focaliza el relato en diversos personajes; y un narrador intradiegético, Guillermo.

Junto con la voluntad de sacar del olvido algunos lances del pasado reciente de Espańa, Grandes propugna un entendimiento alternativo de la historia que incorpore «el papel de la emoción» (Calderón Puerta 2017: 17). ${ }^{13}$ El narrador extradiegético de Inés y la alegría comenta cómo la pasión amorosa hace saltar por los aires los planes cuidadosamente elaborados en los despachos oficiales. Si Monzón no hubiera manipulado a su amante, Carmen de Pedro, para auparse al poder (Grandes 2014a: 38), si la Pasionaria hubiera prestado más atención a la organización de su partido en Francia que a Francisco Antón (Grandes 2014a: 236), el desastre de Arán podría tal vez haberse evitado. El motor de la historia no reside, por tanto, en las decisiones que consensúan los dirigentes tras haber sopesado los pros y los contras, sino en un flujo azaroso de afectos entre individuos que escapa al control oficial: «La Historia [sic] inmortal hace cosas raras cuando se cruza con el amor de los cuerpos mortales» (Grandes 2014a: 23). Los eruditos que combinan «factores económicos, ideológicos, sociales» en «marcos interdisciplinarios y exactos» (Grandes 2014a: 24), prescinden de los gestos, las miradas, los movimientos y las convulsiones que preceden al estallido del «amor de la carne» (Grandes 2014a: 23), con lo cual —así por lo menos se insinúa — su entendimiento del pasado es incompleto. ${ }^{14}$

Aparte del entrelazamiento de las novelas y la reaparición de personajes que aprendió en Balzac, Galdós consagró la anteposición de lo novelesco a lo histórico (Clavería 1957:

12 Promovida por el Partido Comunista, la Operación Reconquista quería provocar un levantamiento popular contra Franco mediante el ataque de un grupo de guerrilleros que, en octubre de 1944, entró en el valle de Arán desde Francia.

13 Sería interesante analizar sus episodios a partir de los estudios sobre el afecto que ha puesto de moda la crítica anglosajona: «Affect [...] is the name we give those forces -visceral forces beneath, alongside, or generally other than conscious knowing, vital forces insisting beyond emotion- that can serve to drive us toward movement» (Seigworth y Gregg 2010: 1).

14 A la escritora madrileńa se le ha achacado el énfasis en las «historias de amor», en detrimento del «sentido objetivo y materialista" (Becerra Mayor 2013: 260) de la historia como disciplina académica. 
175; Hinterhäuser 1963: 242; Gullón 1990: 36) de la que su continuadora se ha apropiado. Si nos ceñimos a la segunda serie de los Episodios nacionales, parece probable que el canario acentuara el componente novelesco por la dificultad de documentarse acerca del reinado de Fernando VII. Su correspondencia con Ramón de Mesonero Romanos abunda en quejas acerca de lo exiguo o defectuoso de sus fuentes, de ahí las peticiones de ayuda que dirige al maestro costumbrista para que comparta con él los recuerdos de aquellos años que tiene almacenados en su prodigiosa memoria: «aprovechando sus generosos ofrecimientos, me tomaré la libertad de ir a apropiarme algo de lo mucho que V. sabe y que me servirá de base para la segunda serie de novelas nacionales» (Pérez Galdós 2016: 36) ${ }^{15}$. Contando con poco más que los dos tomos de la Historia de la vida y reinado de Fernando VII de España (1842) de Estanislao de Kostka Vayo (Pérez Galdós 2012c: 1102) y las conversaciones en casa de don Ramón, Galdós no pudo ejercer de historiador con el rigor con que le habría gustado hacerlo. La manera de paliar este déficit radica en la reconstrucción costumbrista de ambientes — «el vivir, el sentir y hasta el respirar de la gente» (Pérez Galdós 2012c: 1103)—, una cualidad que Mesonero menciona con admiración en una carta del 6 de diciembre de 1877: «es sorprendente, y más para mí que para cualquier otro, la intuición con que se apodera usted de épocas, escenas y personajes que no ha conocido» (Varela Hervías 1943: 27). Nadie como nuestro autor para hacer de la necesidad virtud.

Los episodios de la serie fernandina demuestran, por otro lado, que el pasado reciente influye en la configuración del presente tanto como este facilita la comprensión de aquel. La panorámica del absolutismo concluye con los prolegómenos de la primera guerra carlista que se narran en Un faccioso más y algunos frailes menos (1879), episodio compuesto apenas tres años después de que los ejércitos de Alfonso XII apagaran una insurrección de los partidarios de Carlos VII. Se anudan así dos momentos distantes en el tiempo que desestabilizan el proyecto de edificar la nación. La periodicidad de los levantamientos carlistas verifica la fragilidad del liberalismo a la hora de ultimar la pacificación del país, con efectos perjudiciales que se extienden hasta la Guerra Civil por antonomasia (1936-1939), la que por su magnitud ha de escribirse en singular y con mayúscula. Lejos de restaurar la concordia, el triunfo de Franco ni siquiera elimina el ciclo de revueltas armadas que atraviesa la historia de España. Los guerrilleros de Fuensanta que se enfrentan a la Guardia Civil despliegan el mismo brío que los guerrilleros carlistas que a lo largo del siglo XIX perpetraron una ofensiva tras otra contra el sistema dirigente burgués. Ideológicamente incompatibles entre sí, y dejando de lado la validez de su credo, ambas facciones están comprometidas en la defensa de unos valores a los que no están dispuestos a renunciar.

Cabe decir, por último, que Galdós apela a las emociones como propulsoras de la historia, de acuerdo con la síntesis formulada más adelante en el episodio Montes de Oca (1900): «No hay suceso histórico que interese profundamente si no aparece en él un hilo que vaya a parar a la vida afectiva» (Pérez Galdós 2010: 1054). Las motivaciones de orden anímico suelen estar detrás de ciertos comportamientos que se observan en la vida pública de los protagonistas de la segunda serie: el resentimiento de Monsalud, ser muy superior en talento a su modesta extracción social; la perenne insatisfacción de Genara,

15 La carta está fechada el 18 de mayo de 1875. 
fruto de una equivocación en la elección de marido; o el complejo de inferioridad de Carlos al compararse con su esposa. La exacerbación del sentimiento, tanto o más que las ideas, los lleva a entrometerse en la política, contribuyendo de algún modo con sus acciones al devenir de la monarquía. Igual tendencia se percibe en el personaje histórico por excelencia de la serie, Fernando VII, «harto» (Pérez Galdós 2012b: 977) de los antiguos aliados que se niegan a reconocer a Isabel, y atento al cuidado de sus hijas. La felicidad que experimenta al lado de su cuarta esposa, María Cristina, ablanda su absolutismo hasta el punto de enemistarle con el numeroso séquito de cortesanos que acabarán apoyando a su hermano Carlos. La reina napolitana no es el único ejemplo de mediación femenina en los asuntos de gobierno. La irrupción en la corte de su hermana Carlota deshace en un santiamén la conspiración palaciega que quería entregar el reino al pretendiente, en vez de a la legítima heredera. El narrador, entusiasmado con el coraje de una hembra tan «resuelta, varonil, desparpajada», puntualiza que el reparto de papeles en el «drama» de la historia obedece a criterios de género: en tanto que los hombres "plantean las teorías y los sistemas», las mujeres «determinan la acción» (Pérez Galdós 2012a: 859) a través del amor o el odio.

\section{UN CONFLICTO PERMANENTE, O LA CRÓNICA DE UN DESENCANTO}

La reivindicación que hace Grandes de los valores cívicos de la Segunda República eleva esta al rango de «mito fundacional» (Santamaría Colmenero 2011: 4) de nuestra democracia. La autora misma participó en 2014 en un acto público de homenaje a la República en el municipio de Rivas, con un parlamento en el que pregonó las bondades sin parangón de sus militantes: «la mejor tradición de la historia de este país» (Grandes 2014c: 747-748). Ya dentro de la acción de sus novelas, en Los pacientes del doctor García se describe cómo los madrileños hacen cola en la calle para donar sangre «a la causa de la República» (Grandes 2017: 61); y cómo en las protestas estudiantiles de 1968 se entonaban cánticos en favor de la instauración de dicho régimen: «España, mañana, será republicana» (Grandes 2017: 694). La utopía de la España republicana, descrita como una «arcadia de perfiles a-históricos [sic]» (Gómez López-Quiñones 2006: 278), ${ }^{16}$ la expresan asimismo algunos personajes de ficción. Galán colige que la doctrina del partido, justa, legal y legítima, está puesta al servicio del «honor de España» (Grandes 2014a: 142). Y en los años anteriores a la Guerra Civil, recuerda con nostalgia Pepe el Portugués, el Gobierno y los sindicatos protegían a los desamparados, al revés que en la posguerra, donde no se da «nada por nadie» (Grandes 2014b: 176-177). La pervivencia del ideario republicano está de todos modos asegurada, dado que el gen se transmite por vía familiar a la siguiente generación: Ricardo (Grandes 2014a: 656), Nino (Grandes 2014b: 217), José Antonio (Grandes 2017: 699).

La evocación de un ayer repleto de virtudes contrasta con las deficiencias de la democracia posfranquista desde la que Grandes escribe sus episodios. Su actitud se aleja mucho, por consiguiente, de la complacencia con un presente armónico en el que su-

16 El juicio de Gómez López-Quiñones, anterior a la publicación del primero de los Episodios de una guerra interminable, se dirige contra el alud de películas y novelas del siglo XXI que idealizan los períodos de la Segunda República y la Guerra Civil. Es, por ello, perfectamente aplicable a la obra de Grandes. 
puestamente «nunca pasa nada» (Becerra Mayor 2013: 245). En 1977, la familia de Manolita contempla horrorizada unas imágenes televisivas que muestran a un sonriente Conesa tras la liberación del empresario Antonio María de Oriol y Urquijo y el teniente general Emilio Villaescusa. El antiguo dirigente de la Brigada Política Social, por entonces al mando de la Jefatura Superior de Policía de Valencia, ha dirigido con éxito la todavía hoy controvertida Operación Valencia. La consternación se pinta en los rostros de Manolita y Silverio al preguntarse por qué no se apartó a Conesa de sus funciones con la llegada a la presidencia de Adolfo Suárez. Su enfado llega al colmo cuando el ministro del Interior, Rodolfo Martín Villa, propone que se condecore con la Medalla de Oro al Mérito Policial a quien fue un torturador notorio por su crueldad en los años de la Dictadura. Al recrear este episodio real de la rocambolesca vida de Conesa, la madrileña levanta su voz contra el pacto de silencio de la Transición, que optó — según ella, equivocadamente- por no remover el pasado en busca de un objetivo de mayor calado: la reconciliación nacional. En la misma línea, deplora que el «síndrome de Estocolmo» (Grandes 2014a: 690) que hasta hoy padecen las instituciones y organismos oficiales les impida romper de una vez por todas con la herencia del dictador.

Un «turbio espíritu» (Grandes 2014a: 752) sigue empañando igualmente la memoria de la resistencia antifranquista con la peor de las calumnias: la amnesia. En una entrevista con María Escobedo, la madrileńa acusa de ingratitud a "los padres de la Transición» por haber relegado al olvido el sacrificio de «miles de personas» (Escobedo 2012: 131) que pugnaron por mantener unos derechos que ahora se dan por sentados. El veredicto final subraya la condición anómala de España en el concierto de las naciones europeas, su desajuste endémico con lo que sucede en otras partes. Así lo sintetiza Elena a Nino: «siempre llegamos a todo más tarde o más temprano que los otros» (Grandes 2016b: 236); y María Aránzazu a Guillermo: «o la revolución o el convento, no hay más cáscaras» (Grandes 2017: 263). A una democracia que ha recompensado a quienes la combatieron y traicionado a quienes la hicieron posible, no se la debe calificar en absoluto de modélica. El desaliento de la autora se plasma en una pregunta retórica de Inés: «ipero qué hemos hecho nosotros para merecernos esto?» (Grandes 2014a: 736).

A falta de las dos novelas que han de completar el ciclo, me atrevería a aventurar que el desánimo de Grandes va creciendo a medida que la trama se aleja del tiempo mítico de la inmediata posguerra. Hasta el desenlace de Los pacientes del doctor García, los protagonistas se las ingenian para subsistir en la atmósfera asfixiante de la Dictadura, o en el nuevo país que los acoge, movidos — más allá del amor — por el ansia de libertad, la integración solidaria en la comunidad, el deseo de crear un mundo mejor, el orgullo de la derrota, la fidelidad a una doctrina o la lucha diaria por la supervivencia. La esperanza los compensa siempre, pues, de las múltiples penalidades que arrostran: la huida del país natal (Inés y Galán, los guerrilleros de la Sierra); la frustración de que Franco continúe detentando el poder (Inés); la represión por parte de las autoridades gubernamentales (los habitantes de Fuensanta) o religiosas (Isabel); la vida como simulacro (los habitantes de Fuensanta) o claudicación (Guillermo); la tortura (los detenidos en Fuensanta, Antonio); la cárcel (Nino, Silverio); la arbitrariedad de la justicia (los habitantes de Fuensanta); las dificultades para sacar adelante a la familia (Manolita); o el miedo a la delación (Guillermo). El personaje de Manuel, sin embargo, ya no está dotado de un espíritu infatigable que le permita resarcirse de las contrariedades apelando a la nobleza 
de unas aspiraciones incumplidas. El escepticismo que ha penetrado en su ser al darse cuenta de que nada de lo que ha hecho ha valido la pena, tiene visos de ser una dolencia grave que la felicidad del hogar nunca logrará curar del todo.

De confirmarse la hipótesis de que los Episodios de una guerra interminable van conformando una crónica del desencanto, podría hablarse de una apropiación temática que sigue un curso similar al que traza Galdós entre el último episodio de la primera serie, La batalla de los Arapiles, y el primero de la segunda, El equipaje del rey José. El júbilo de la victoria en la cima del Arapil Grande no tarda en desembocar en una explosión de odio, violencia y pillaje de los guerrilleros contra los afrancesados en la batalla de Vitoria, todo ello en el transcurso de los apenas cuatro meses que separan la escritura de una y otra narración. No solo en la novela inicial, sino en todas las restantes de la segunda serie, predomina un tono sombrío (Bergamín 1957: 106) reminiscente de los Desastres de la guerra de Francisco de Goya (Bergamín 1957: 106; Smith 2009: 473; Muñoz Molina 2011).

La ausencia de luz es la manifestación artística de las tribulaciones políticas del canario en la década de 1870. Los artículos periodísticos que publica entre 1871 y 1872 en la Revista de España ensalzan la Constitución de 1869 como la única vía a la conciliación, ${ }^{17}$ de ahí que el fracaso en su implementación le aseste un golpe muy duro: «l'auteur est sous le coup de l'abbatement lié à la restauration des Bourbons" (Beyrie 1980: 217). De la misma manera que redacta la primera serie de los Episodios nacionales cuando aún confía en el arraigo del liberalismo democrático, la segunda es el fruto amargo del Pronunciamiento de Sagunto del general Arsenio Martínez Campos. El canario lamenta en su fuero interno el retroceso de las libertades públicas y privadas tras el regreso de la dinastía borbónica, parte de una «ofensiva reaccionaria» (López 2014: 26) enmarcada en las guerras culturales de la segunda mitad de la década de 1870. La crisis espiritual que lo aqueja se traslada inmediatamente a las páginas de la ficción histórica, y poco después también a sus novelas ideológicas. Uno de los portavoces del autor, Gabriel Araceli, reaparece brevemente en el episodio Memorias de un cortesano de 1815 para impugnar sin tapujos la decadencia del Sexenio Absolutista: «No hay ejemplo de una esterilidad más espantosa, ni jamás ha sido el genio español tan eunuco» (Pérez Galdós 2011a: 341). Mientras la idea de «nacionalidad» (Pérez Galdós 2005: 779) se consolida durante la guerra de la Independencia, el reinado de Fernando VII propicia el brutal choque de ideologías: «¡Viva el pueblo! ¡Viva la libertad!», grita el pueblo en 1823; a lo que replican Carlos Garrote y sus esbirros: « Viva el rey! ¡Viva la religión!» (Pérez Galdós 2011b: 586). La inestabilidad de aquellos años se intensifica con la muerte del monarca, dando lugar a una conflagración fratricida que clausura la segunda serie. En un impecable ejercicio de simetría narrativa, Galdós abre y cierra la acción en los campos de batalla, con un enfrentamiento entre dos hermanos y la amenazadora presencia de los guerrilleros en el contexto de una pugna dinástica. La repetición hace más evidente, en suma, el insaciable belicismo de sus compatriotas: «La paz es aquí un prepararse para la lucha, y un ponerse vendas y limpiar armas para empezar de nuevo» (Pérez Galdós 2012a: 672).

17 Así lo expresa el 28 de abril de 1872: «la Constitución, cuyo cumplimiento exacto ha de ser siempre la única bandera que pueden levantar dignamente los Gobiernos revolucionarios» (Pérez Galdós 1982: 99). 
Que la Restauración alfonsina coincida con otra revuelta carlista ańade una dimensión diacrónica al antagonismo entre absolutistas y liberales, tema central de la serie según declaración del autor: «otras diez narraciones, consagradas [...] a las luchas entre la tradición y la libertad» ${ }^{18}$. Como reconoce con amargura Monsalud en las últimas páginas, el cainismo que se ha instalado en la psique de sus compatriotas no lleva camino de marcharse ni a corto ni a medio plazo: «Los días mejores [...] están aún tan lejos que seguramente ni usted [Benigno Cordero] ni yo los veremos» (Pérez Galdós 2012b: 1093). El vaticinio de Monsalud se lo apropia Nino más de un siglo después, ubicándolo en la época que le ha tocado vivir: «Había estallado una guerra que había partido a España en dos mitades» (Grandes 2014b: 35). En una última vuelta de tuerca al binomio Galdós-Grandes, el sintagma "guerra interminable» acaba significando una cosa distinta que la incesante lucha de comunistas y republicanos contra Franco. Una segunda acepción, de marcado acento negativo, tergiversa el sentido original del término al ampliar su radio de acción a toda la historia contemporánea de España. En virtud de este giro semántico, el mensaje que lanzan uno y otro escritor alerta del perverso enquistamiento de la reacción, monstruo policéfalo que renace como ave fénix para obstaculizar el progreso y la convivencia. Absolutistas, realistas, apostólicos, carlistas, falangistas y franquistas, no cejan en su empeño de adueñarse del poder saltándose sin escrúpulos las leyes humanas en nombre de las divinas, en las que tampoco creen con la fe sincera del cristianismo. Por eso la libertad no echa raíces, ni tras la muerte de Fernando VII ni tampoco tras la proclamación de la Segunda República. El absolutismo al que Monsalud pronosticaba una dilatada existencia dista mucho, pues, de haberse agotado, solo ha evolucionado para adaptarse a los nuevos tiempos. Manuel lo ha sufrido en sus carnes por partida triple, bajo la moderna denominación de dictaduras, en la España de Franco, en la Argentina de Perón y en la Argentina de la Guerra Sucia: «Todo igual, aquí y allí, siempre igual, lo mismo en todas partes» (Grandes 2017: 734). El resurgimiento global del populismo de derechas en la segunda década del siglo XXI, incluida Espańa, no hace sino corroborar el aserto de los dos novelistas.

\section{CONCLUSIONES}

La vigencia del legado galdosiano que han alentado novelistas como Rafael Chirbes, Antonio Muñoz Molina y Grandes se orienta en una doble vertiente: literaria, mediante el cultivo de un «realismo posmoderno» que vuelve a priorizar la «mímesis» (Oleza 1996: 8) y la narratividad; y política, en tributo al gran adalid del liberalismo español (Berkowitz 1948). En el caso concreto de Grandes, la influencia del maestro canario se extiende a la utilización del marbete «episodios» en el título de sus todavía inacabados Episodios de una guerra interminable. La adscripción a un subgénero inaugurado en la década de 1870 , abiertamente reconocida por la madrileña, se complementa con la solapada absorción de motivos, personajes y técnicas procedentes de la segunda serie de los Episodios nacionales. Al fusionar la reivindicación con la apropiación, nuestra autora se adhiere a una poética y una ideología afines a las de Galdós.

18 Opinión mayoritariamente refrendada por la crítica: Regalado García 1966: 85; Montesinos 1968: 120; Dendle 1986: 88; Navascués 1987: 493; Troncoso 2006: 8. 
El primer apartado de este trabajo se centra en los rasgos en común que los héroes, heroínas y villanos de Grandes tienen con los protagonistas del ciclo fernandino: el desengaño revolucionario (Salvador Monsalud), la emancipación femenina (Genara Baraona), la domesticidad (Solita Gil de la Cuadra) y la sinrazón (Carlos Navarro). El apartado siguiente se ocupa de la historia como intertexto de la trama ficticia, patente en el uso de fuentes escritas y orales, el propósito pedagógico y el peso de lo emocional en el desarrollo de los sucesos, así como en la articulación de un leitmotiv que ha incidido negativamente en el proceso de construcción de la nación moderna: la incompatibilidad entre el desiderátum de progreso y la onerosa carga del pasado. Finalmente, se hace hincapié en la guerra interminable que vienen librando absolutismo y liberalismo en los últimos dos siglos, desde el levantamiento contra Napoleón hasta la implantación de la democracia posfranquista. Ni Galdós ni Grandes esconden su desencanto al constatar la pertinaz resistencia de la reacción frente al proyecto reformista de liberales y republicanos. En última instancia, la nociva circularidad de nuestra historia explica el pesimismo que rezuman las dos series de Episodios que se han analizado aquí. 



\title{
CAPÍTULO VII
}

\author{
Bibliografía de las traducciones de Benito Pérez Galdós \\ Isabel Pascua Febles y M. ${ }^{\text {a }}$ Isabel García Bolta \\ Universidad de Las Palmas de Gran Canaria
}

\section{INTRODUCCIÓN}

En febrero de 2019, en la Casa-Museo Pérez Galdós, se presentó el libro Pérez Galdós en el vértice. Veinticuatro miradas. Ese mismo día, se publicó en la prensa local una entrevista a uno de los autores participantes en esta obra, Rodolfo Cardona, profesor emérito de la Universidad de Boston, decano de los galdosianos y fundador de la revista Anales Galdosianos en 1965.

Al preguntarle el entrevistador cómo se contemplaba la obra de Galdós fuera del mundo hispanoamericano, comentó que aunque en su opinión Galdós puede ser tan actual como otros autores del siglo XIX (Tolstói, Dickens, Balzac, etc.), desgraciadamente no ha obtenido la popularidad que merece, fuera del mundo hispánico, debido a la falta de más traducciones. Esta afirmación nos sorprendió de forma grata, pues coincidió con que en esa época ya se preparaba el presente volumen monográfico sobre «Traducción y recepción universal de Benito Pérez Galdós: cien años después (1920-2020)», como homenaje al autor en el centenario de su fallecimiento.

De ahí surgió la idea de investigar y llevar a cabo una bibliografía de las traducciones de D. Benito como objetivo del presente trabajo, para conocer la difusión de su obra fuera de España y, en la medida de los posible, averiguar cuántas se han editado y cuáles han sido las más difundidas para apreciar su evolución. En el presente volumen la traducción se entiende en el sentido amplio de los estudios actuales de la postraducción que defienden Scott (2012) y Gentzler (2017) — de la traducción interlingual a la intralingual o intermedial—, por lo que se podrían contemplar estudios sobre sus obras, adaptaciones (literarias, teatrales o cinematográficas, etc.) e incluso apropiaciones de sus títulos. Sin embargo, en este trabajo, nos ceñiremos a las traducciones, en sentido tradicional, de sus obras a diferentes lenguas, tanto de España como de otros países.

$\mathrm{Al}$ comenzar la búsqueda en todas las fuentes bibliográficas a nuestro alcance, partimos del convencimiento de que no sería fácil que las obras antiguas estuvieran bien reseñadas, pues, además de que en el siglo XIX y principios del XX el traductor era considerado 
casi invisible, tampoco existía la misma rigurosidad en las normas en todos los países encontrados, al referenciar las fechas o lugares de edición.

Una de nuestras primeras fuentes fue el artículo sobre la obra traducida en vida del novelista (García Bolta 1993). En dicho estudio descubrimos que, en ese período, la obra de Galdós se tradujo a once lenguas: italiano, alemán, francés, inglés, danés, checo, holandés, sueco, rumano, húngaro y ruso. Según observó la autora en sus conclusiones, las obras que se tradujeron primero fueron precisamente las que en España tuvieron más número de ediciones y de lectores. Quizá lo que se buscaba no era tanto estudiar al escritor o el valor de su obra sino esa España típica del modelo de Doña Perfecta (ibid.: 54), o incluso conocer lo español a través de una lectura fácil. Por esta misma razón, la autora señalaba que la difusión de Los Episodios nacionales tuvo menor resonancia fuera de España.

En la primera parte de nuestro trabajo, llevado a cabo durante 2019, señalamos las obras que habíamos encontrado traducidas a veintinueve lenguas diferentes (alemán, árabe, búlgaro, catalán, checo, chino, danés, eslovaco, estonio, farsi, finés, francés, gallego, griego, hebreo, holandés, húngaro, inglés, italiano, japonés, malabar, noruego, polaco, portugués, rumano, ruso, serbio, suajili y sueco). Para la actual clasificación se ha seguido el orden alfabético de las diferentes lenguas y, dentro de cada grupo, las ediciones por orden cronológico y por géneros según fueran novelas, episodios, teatro y cuentos.

Debemos señalar que hemos recogido la información tanto en catálogos de bibliotecas nacionales como en ponencias de diversos congresos, trabajos en revistas especializadas y tesis dostorales. Igualmente nos ha interesado la ofrecida en entrevistas a galdosianos e hispanistas, además de la hallada en grandes librerías con fondos antiguos, es decir, en todas las fuentes posibles. Por tanto, al ser muy heterogéneas y de países y épocas muy diferentes, hemos reseñado las obras con los datos que aparecían en las distintas fuentes. De ahí que, en alguna lengua extranjera aparecezcan obras sin traductor y títulos en espańol junto a otros en su versión original latinizados o no.

Con el objetivo de mostrar una mayor claridad, ofrecemos el apartado "Otras ediciones» que contiene, de un lado, las obras del escritor traducidas a otras lenguas si bien con escasos datos, y de otro, aquellas publicaciones con estudios y notas en español, impresas fuera de España.

Tras la bibliografía de las traducciones, incluiremos un apartado sobre los traductores y lectores de Pérez Galdós, para finalizar con algunas conclusiones sobre la difusión y recepción internacional de ediciones aparecidas tanto en vida de Galdós como en estos últimos cien años, desde el fallecimiento del autor.

\subsection{Principales fuentes de información bibliográfica:}

Academia Editorial del Hispanismo https://academiaeditorial.com

Actas de los Congresos Internacionales de Estudios Galdosianos: actascongreso.casamuseoperezgaldos.com

Anales Galdosianos: https://www.bu.edu > analesgaldosianos

Biblioteca Casa-Museo Pérez Galdós. Catálogo: www.casamuseoperezgaldos.com > biblioteca-y-archivo 
Biblioteca Nacional de Alemania. Catálogo: https://www.dnb.de > Home > home_node German National Library - Deutsche Nationalbibliothek

Biblioteca Nacional de España. Catálogo: www.bne.es > Catalogos

Biblioteca Pública de Estocolmo. Catálogo: Stockholms stadsbibliotek https://biblioteket.stockholm.se

Biblioteca Nacional de Bulgaria Catálogo Centro de Recursos de Bulgaria del Ministerio de Educación: https://www.educacionyfp.gob.es > bulgaria > oficinasycentros > cen= tros-re

Biblioteca Nacional de Grecia. Catálogo: https://www.ert.gr/eidiseis/politismos/o-benito-perez-galdos-kai-to-niaoy-grafei-o-tasos-psarris/

Biblioteca Estatal y Universitaria de Hamburgo. Catálogo: www.iberialiber.de s sub_ hamburg_es

Biblioteca Nacional de Rusia. Catálogo: https://es.rbth.com > http://www.nlr.ru/.

Biblioteca Virtual Miguel de Cervantes. Catálogo: www.cervantesvirtual.com > catalogo The British Library: https://www.bl.uk

OPAC Biblioteca Centrale Roma: www.bncrm.beniculturali.it > cataloghi

Catalog of Copyright Entries: https://onlinebooks.library.upenn.edu > cce

Centro Virtual Cervantes: https://cvc.cervantes.es

Harvard: https://library.harvard.edu/digital-collections

Hathi Trust. Digital Library: https://www.hathitrust.org

Isidora. Revista de Estudios Galdosianos: www.isidoraediciones.com > isidora-revista

Jersey Library Catalogue: https://capitadiscovery.co.uk , jersey

Staatsbibliothek en Berlín: https://staatsbibliothek-berlin.de > recherche > kataloge

IberLibro.com: https://www.iberlibro.com

Convocatorias Ayudas para el fomento de la traducción a lenguas extranjeras. Ministerio de Educación, Cultura y Deporte. España.

\section{Bibliografía de las traducciones de obras de Pérez Galdós (1872-2019)}

\section{Traducciones al alemán:}

\section{NOVELAS}

- Gloria. 1880. Berlín: Verlag von L. Schleiermacher in zwei theilen. Traducción de Dr. Aug. Hartmann.

- Doña Perfecta. 1886. Dresden \& Leipzig: Pierson’s Verlag. Traducción de Julianna Emilie Reichel.

- Gloria. 1886. Dresden und Leipzig: Pierson's Verlag. Traducción de Julianna Emilie Reichel.

- Marianela. 1888. Breslau: Auterhaltunsblatt. Traducción de Emilia Plücher.

- Marianela. Freund Manso. 1888. [Marianela. El amigo Manso]. Breslau: Auterhaltunsblatt. Traducción de Emilia Plücher. 
- Freund Manso. 1894. [El amigo Manso]. Berlín: Verlag von Karl Siegismund. Traducción de Eugène Buddenbrock.

- Doña Perfecta. 1903. Dresden: Pierson's Verlag. Traducción de Julianna Emilie Reichel.

- Marianela. 1903. Berlín: A. Weicher. Traducción de Emil Jonas.

- Miau. 1960. Hamburgo: Maximilian-Gessellschaft. Traducción de Wilhelm Heinse.

- Miau. 1960. Berlín. Traducción de Wilhelm Muster.

- Miau. 1960. Frankfort: Suhrkamp Verlag. Traducción de Wilhelm Muster.

- Fortunata und Jacinta. 2 Geschichten von Ehefrauen. 1961. [Fortunata y Jacinta]. Zurich: Manesse Verlag. Conzett und Huber. Epílogo de Arnald Steiger. Traducción de Kurt Kuhn.

- Misericordia. 1962. Leipzig: Dieterisch'schen Verlagsbuchhanddlung. Epílogo de Adalbert Dessau. Traducción de F.R. Fries; Ruth Vollrath-Wirth.

- Doña Perfecta. 1963. Berlín: Aufbau-Verlag. Traducción de Egon Hartmann.

- Doña Perfecta. 1964. Zurich: Manesse Verlag. Traducción de Kurt Kuhn.

- Amigo Manso. 1964. Zurich: Manesse Verlage. Manesse Bibliothek der Weltliteratur. Epílogo de Christoph Eich. Traducción de Kurt Kuhn.

- Misericordia. 1971. Leipzig: Dieterich. Traducción de F. R. Fries; R. VollrathWirth.

- La Fontana de Oro. 1972. Leipzig: F. A. Brockaus.

- Doña Perfecta. 1974. Weimar: Aufbau-Verlag. Traducción de Egon Hartmann.

- Amigo Manso. 1983. Berlín: Buchclub 65. Traducción de Wilhelm Plackmeyer; Kurt Kuhn.

- Miau. 1983. Frankfort: Suhrkamp Verlag. Traducción de Wilhelm Muster.

- Miau. 1983. Frankfort: Suhrkamp. Epílogo de Rafael de la Vega. Traducción de F. R. Fries; Ruth Vollrath-Wirth.

- Fortunata und Jacinta.1983. [Fortunata y Jacinta]. Zurich: Manesse Verlag. Traducción de Kurt Kuhn.

- Doña Perfecta. 1989. Munich: Winkler. Estudio de Horst Weich. Traducción de Egon Hartmann.

- Tristana. 1989. Frankfort: Suhrkamp; Bibliotethek Suhrkamp; Bd.1013. Epílogo y traducción de Erna Pfeiffer.

- Tristana. 1991. Frankfort: Suhrkamp. Traducción de Erna Pfeiffer.

- Doña Perfecta. 1992. Frankfort: Fischer Verlag. Traducción de Egon Hartmann.

- Marianela. 1994. Cadolzburg: Ars-vivendi-Verlag. Epílogo de María-Paz Yánez. Traducción de Gertraud Strohm-Katzer; Carmen Wurm.

- Doña Perfecta. 1998. Berlín: Aufbau Bibliothek.

- Marianela. 2000. Munich: Deutscher Taschenbuch- Verlag. Dtv. [televisión digital]. Traducción de Gertraud Strohm-Katzer; Carmen Wurm. 
- Tristana. 2008. Stuttgart: Ernst Klett Verlag.

- Marianela. 2009. Lektüre mit Audio-CD. 1. Aufl. Ismaning: Hueber Verlag.

- Nazarín. 2013. Norderstedt: Books on Demand. Ed. Peters R.

\section{EPISODIOS NACIONALES}

- Trafalgar. 1896. Dresde und Leipzig: Reitzner Verlag. Trad. Hans Parlow.

- Der Roman einer nonne. 1902. [La campaña del Maestrazgo]. Viena / Budapest / Leipzig: Sachs und Pollack.

- Trafalgar. 1925. Bielefeld und Leipzig: Velhagen und Klasing.

- Trafalgar. Die Abenteuer der Pepita González. 1997. Bergisch Gladbach: BasteiVerl. Lübbe-Taschenbuch. Traducción de Werner Siebenhaar; Renate Kunze.

- Der Aufstand von Madrid. Bailén. 1997. [El 19 de marzo y el 2 de mayo. Bailén]. Dt. Erstveröff, Bergisch Gladbach: Bastei-Lübbe. Traducción de Werner Siebenhaar.

- Napoleón in Chamartín. Zaragoza. 1998. [Napoleón en Chamartín. Zaragoza]. Zwei historische Romane. Dt. Erstveröff. Bergisch Gladbach: Bastei-Verl. Lübbe. Klassiker des historischen Romans. Eds. Edgar Bracht. Traducción de Werner Siebenhaar.

- Der Belagerung von Gerona. Cádiz 1999. [Gerona. Cádiz]. Zwei historische Romane. Bergisch Gladbach: Bastei-Lübbe. Traducción de Werner Siebenhaar.

- Juan Martín. Die Schlacht bei den Arapiles-Hügeln. 1999. [Juan Martín el Empecinado. La batalla de los Arapiles]. Bergisch Gladbach: Bastei-Lübbe. Traducción de Werner Siebenhaar.

- Der Roman einer Nonne. 2012. [La campaña del Maestrazgo]. Hamburgo: tredition. Traducción de Dońa Servita.

\section{TEATRO}

- Electra. 1901. Viena: Wiener Verlage. Traducción de Rudolf Beer.

- Electra. 1901. Berlín: [s. n.]. 6 reimpresiones en 1901. Adaptación de Ricardo Fellner. Traducción de Rudolf Beer.

\section{Cuentos}

- Ein Roman in der Strassenbahn. 1908. [La novela en el tranvía]. En Aus Frenden Zungen, no8, pp. 678-691. Traducción de U. Rudolph.

- Der Och.se und der Esel. 1958. [La mula y el buey]. Spanische Erzäbler des 19 und 20 Jahrhunderts. [Narración española de los siglos XIX y XX]. Zurich: Manesse Verlag. Edit. Wener Peiser; Albert Theile.

- Der Roman in der Strassenbahn. 1961. [La novela en el tranvía]. Munich:Ebenhausen: Langewiesche-Brandt. Traducción de Karl Dufner.

- Der Roman in der Strassenbahn. 1984. [La novela en el tranvía]. Munich: Deutscher Taschenbuch- Verlag. Traducción de Karl Dufner. 


\section{Traducciones al árabe:}

NOVELAS

- Marianela. 2009. Tánger: Litograf. Traducción de Omar Bouhachi.

- Fortunata y Jacinta. 2010. El Cairo: Darat al- Karaz. Traducción de Hala Awwaad.

- 2011. [Tristana.] El Cairo: Afaq. Traducción de Safa Ragab.

- Doña Perfecta. 2013. Tánger: Litograf. Traducción de Omar Bouhachi.

- Tormento. 2013. Tánger: Litograf. Traducción de Seddik Ahmidouch.

- 2014. [Doña Perfecta]. Madrid: Isidora Ediciones. Traducción de Omar Bouhachi.

- Märiyānīlā. 2014. [Marianela]. Madrid: Isidora Ediciones. Traducción de Omar Bouhachi.

\section{EPISODIOS NACIONALES}

- Aita Tettauen. 2008. Madrid: Isidora Ediciones. Traducción de Omar Bouhachi.

- Bailén. (Capítulos I, II). 2011. Madrid: Isidora. Revista de Estudios Galdosianos, n. ${ }^{\circ}$ 17, pp. 183-191. Traducción de Hayam Farrag.

- Aita Tettauen. 2011. Tánger: Litograf. Traducción de Omar Bouhachi.

- Bailén. (Capítulos III, IV). 2013. Madrid: Isidora. Revista de Estudios Galdosianos, n. ${ }^{\circ}$ 21, pp. 199-210. Traducción de Hayam Abdou Mohamed.

- Bailén. (Capítulos V, VI, VII, VIII, IX, X). 2014. Madrid: Isidora. Revista de Estudios Galdosianos, n. ${ }^{\circ}$ 24, pp. 215-236. Traducción de Hayam Abdou.

- Aita Tettauen. (Capítulos 1, 2). 2014. Madrid: Isidora. Revista de Estudios Galdosianos, n. ${ }^{\circ}$ 24, pp. 205-214. Traducción de Omar Bouhachi.

- Aita Tettauen. 2014. Madrid: Isidora Ediciones. Traducción de Omar Bouhachi.

\section{TEATRO}

- El tacaño Salomón. 2008. Madrid: Isidora. Revista de Estudios Galdosianos, n. ${ }^{\circ}$ 6, pp. 203-238. Traducción de Amru Muhammad Said.

- 2014. [Alceste] Madrid: Isidora Ediciones. Traducción de Omar Bouhachi.

- 2013. [El tacaño Salomón]. Madrid: Isidora Ediciones. Traducción de Amru Muhammad Said.

\section{Cuentos}

- La conjuración de las palabras. 2005. Madrid: Isidora. Revista de Estudios Galdosianos, n. ${ }^{\circ}$ 1, pp. 163-168. Traducción Manar Abd.

- La pluma en el viento o el viaje de la vida. 2006. Madrid: Isidora. Revista de Estudios Galdosianos, n. ${ }^{\circ}$ 2, pp. 251-261. Tradución de Manar Abd El Moez Ahmed; Abir Mahamed Abd El Salam. 
- La princesa y el granuja. 2007. Madrid: Isidora. Revista de Estudios Galdosianos, n. ${ }^{\circ}$ 4, pp. 193-209. Traducción de Manar Abd El Moez Ahmed; Abir Mahamed Abd El Salam.

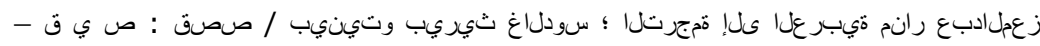
[حم. 2007. [Theros]. 2007. Madrid: Isidora. Revista de Estudios Galdosianos, n. ${ }^{\circ}$ 5, pp. 207-220. Traducción de Manar Abd El Moez Ahmed.

- La conjuración de las palabras. 2013. Madrid: Isidora Ediciones. Traducción de Manar Abd El Moez Ahmed.

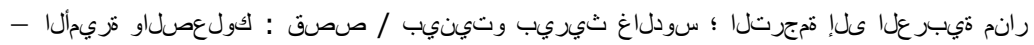
La princesa y el granuja]. 2013. Madrid: Isidora Ediciones. Traducción de Manar Abd El Moez Ahmed; Abir Mahamed Abd El Salam.

- Fys: qisas. 2013. [Theros]. Madrid: Isidora Ediciones. Traducción de Manar Abd El Moez Ahmed.

\section{Traducciones al búlgaro:}

NOVELAS

- Фортуната и Хасинта. Fortunata i Hasinta. 1984. [Fortunata y Jacinta]. Sofía: Otecestven Front. Traducción de Bojan Conev et al.

- Фортуната и Хасинта. Fortunata i Hasinta. 1991. [Fortunata y Jacinta]. Sofía: Evrika-AVI; Gulev. Traducción de Bojan Conev et al.

- Tристана. Назарин. [Tristana. Nazarín]. 2014. Sofia: Persei. Traducción de Rumen Rumenov Ivanov.

- Мияу. Марианела. [Miau. Marianela]. 2015. Sofía: Persei.

- Tристана. [Tristana]. 2019. Edit. Patak Konyvek-Triana BT. Traducción de Marta Pávai Patak.

\section{EPISODIOS NACIONALES}

- Capazoca [Zaragoza]. 1968. Sofía: Naropdna Miradex. Traducción de Anna Gueorguieva.

- Трафалгар[Trafalgar]. 1972. Sofía: Naropdna Kultura. Traducción de Teodoro L. Neikov.

- Кадис / Доня Перфектна. [Cádiz. Doña Perfecta]. 1976. Sofía: Naropdna Kultura. Traducción de Teodoro L. Neikov.

- Трафалгар / Доня перфектна/ 19 март и 2 май / Байлен / Сарагоса / Кадис/ дворът на Карлос IV / Милост. [Trafalgar, Doña Perfecta. El 19 de marzo y 2 de mayo. Bailén. Zaragoza. Cádiz. La Corte de Carlos IV. Misericordia]. 1984. 2 vols. Sofía: Naropdna Kultura. Traducción de Izbrani Tvorbi (vol.1).

- Трафалгар/дворът на Карлос IV/ 19 март и 2 май. [Trafalgar. Dvorat na Karlos IV. 19 mart i 2 maj. 1984. [Trafalgar. La Corte de Carlos IV. El 19 de marzo y el 2 de mayo]. 1984. Sofía: Naropdna Kultura. Traducción de Izbrani Tvorbi; Teodoro L. Neikov; Emilia Julzari. 
- Байлен / Сарагоса / Кадис. 1985. [Bailén. Zaragoza. Cádiz]. Sofía: Antonaeta Damjanova et al. Naropdna Kultura. Traducción de Izbrani Tvorbi.

\section{Traducciones al catalán:}

EPISODIOS NACIONALES

- Girona. 1930. [Gerona]. Barcelona: Antonio López. Traducción de J. Burgas.

\section{TEATRO}

- Marianela. 1934. Escenificación de la novela del mismo título de B. Pérez Galdós por S. y J. Álvarez Quintero. Barcelona: Librería Millá. Traducción de Antoni Carner.

- El vell Albrit. 1937 [El abuelo]. Barcelona: Librería Bonavia. Traducción de Agustín Collado.

- Girona. Episodi Nacional i drama en quatre actes. 2010. [Gerona]. Madrid: Isidora Ediciones. Traducción de Pau Miret.

\section{Cuentos}

- La conjuració de les paraules. 2006. [La conjuración de las palabras]. Madrid: Isidora. Revista de Estudios Galdosianos, n. o 2, pp. 225-231. Traducción de Amadeu Viana.

\section{Traducciones al checo:}

NOVELAS

- Nazarín. 1897. Praga: Vilímek. Traducción de A. Pikhart.

- Marianela. 1904. Praga: Otto. Traducción de J. V. Sládek.

- Zebráci. 1928. [Misericordia]. Praga: Ustrední delnické Knilhkupecteví a nakladatelství. Traducción de Mil Nováková.

- Doña Perfecta. 1936. Praga: Ustrední delnické Knilhkupecteví a nakladatelství. Traducción de Mil Nováková.

- Marianela. 1936. Praga: Ustrední delnické Knilhkupecteví a nakladatelství. Traducción de Mil Nováková.

- Doña Perfecta. 1950. Praga. Traducción de Eduard Hodousek.

- Doña Perfecta. 1959. Bratislava. Traducción de Tibor Kobán.

- Marianela. 1979. Praga: Mladá Fronta. Traducción de Hanna Posseltová.

\section{EPISODIOS NACIONALES}

- General Juan Martín. 1950. [Juan Martín el Empecinado]. Traducción de Jarmilla Koapilové.

- General Juan Martín. 1953. [Juan Martín el Empecinado]. Praga. Traducción de Jarmilla Koapilové.

- Zaragoza. 1955. Praga: Státní Nachadatelství. Krásné Literatury, Hudby a Umení. Traducción de Marcela Svodová. 
- Zaragoza. 1964. Bratislava: Slovenské vydavatelstvo. Krásnej Literatury. Traducción de Josef Skultéty.

\section{TEATRO}

- Elektra. 1901. [Electra]. Praga. Traducción de Andrej Xueera.

\section{Traducciones al chino:}

\section{NOVELAS}

- Bei fei da fu ren. 1961. [Doña Perfecta]. Pekin: Ren min wen xue chu ban she. Traducción de Qingshen Zhao.

- Marianela. 1982. Hunan: Ed. Pueblo de Hunan. Traducción de Mingjiang Yang.

- Marianela. 1982. Yunnan: Ed. Pueblo de Yunnan. Traducción de Guangfu Cheng; Ying Liu; Xinghe Zhu.

- Gloria. 1985. Traducción de Mengquan Wang; Shaotian Zhao.

- Fuertunata he haxinta. 1987. [Fortunata y Jacinta]. Chongqing, Xiejiawan: Chongqing Publishing. Traducción de Xiancheng Meng.

- Nazarin. 1990. Traducción de Zhiquan Wang; Zongcao Jiang.

- Fortunata y Jacinta. 1992. Chongqing: Chongqing Publishing. Traducción de Xiancheng Meng.

- Halma. 1993. Heilongiangi, Harbin: Ed. Pueblo de Heilongiangi. Traducción de Yiunfu Wang.

- 佩菲塔夫人/贝·佩·加尔多斯, 著; 李德明, 译. 1996. [Doña Perfecta]. Harbin: Heilongiangi ren min. Traducción de Deming Li.

- Jin Quan. 1999. [La Fontana de Oro]. Shanghái: Shangái hai yi wen chu ban she. Traducción de Zhiquan Wang; Zongcao Jiang; Chendong Yin.

- Mansuo pengyou. 1999. [El amigo Manso]. Shanghái: yi wen chu ban she. Traducción de Zongcao Jiang.

- 特里斯塔娜 / [加尔多斯] ; 尹承东, 译. 1999. [Tristana]. Shanghái: Shangái yi wen. Traducción de Chengdong Yin.

- Fuertunata he haxinta. 2000. [Fortunata y Jacinta]. Shanghái: yi wen chu ban she. Traducción de Xiaoli Wang.

- 托尔门多/[加尔多斯] ; 李德明, 译. 2002. [Tormento]. Shanghái: Shanghái yi wen. Traducción de Deming Li.

- Tang na pei fei keta. 2003. [Doña Perfecta]. Shanghái: Shanghái hai yi wen chu he. Traducción de Maogen Yen.

- Perfeita fu ren. 2004. [Doña Perfecta]. Shijiazhuang: hua sham wen yi chu ban she. Traducción de Yongda Wang.

- Geluoliya. 2005. [Gloria]. Shanghái: Shanghái Translation Publishing House. Traducción de Zhiquan Wang; Deming Zhao.

- Man suo peng. 2005. [El amigo Manso]. Pekín: Ren min wen xue chue ban see. Traducción de Shuangcheng Bian. 
- 安赫尔·格拉 / [加尔多斯]; 李德明, 译. 2006. [Ángel Guerra]. Shanghái: Shanghái yi wen. Traducción de Deming Li.

\section{EPISODIOS NACIONALES}

- Zaragoza. 1982. Shanghái: Ed. Yiwen. Traducción de Shen Baolou; Cai Huawen.

- El 19 de marzo y el 2 de mayo. 1983. Shanghái: Ed. Yiwen. Traducción de Shen Baolou; Cai Huawen.

\section{Cuentos}

- La conjuración de las palabras. 2005. Madrid: Isidora. Revista de Estudios Galdosianos, n. ${ }^{\circ}$ 1, pp. 181-186. Traducción de Dong Yansheng.

\section{Traducciones al danés:}

\section{NOVELAS}

- León Roch. 1881. Copenhague: Andr. Schous Forlag.

- Fru Perfecta.1895. [Doña Perfecta]. Copenhague: Wilhelm Prios Forlag.

- Torquemada. 1898. Copenhague: Kristiania. Traducción de Johanne Allen.

\section{Cuentos}

- La conjuración de las palabras. 2005. Madrid: Isidora. Revista de Estudios Galdosianos, n. ${ }^{\circ}$ 1, pp. 175-180. Traducción de Lene Waagstein.

\section{Traducciones al eslovaco:}

\section{NOVELAS}

- Doña Perfecta. 1959. Bratislava. Traducción de Tibor Kodan.

- Fortunata y Jacinta. 1982. Bratislava: Slovensky Spisovatel. Traducción de Katarina Jusková.

\section{EPISODIOS NACIONALES}

- Zaragoza 1964. Bratislava. Traducción de Jozef Skultéty.

\section{Traducciones al estonio:}

NOVELAS

- Osatu. 1979. [La desheredada] Tallin: Eesti Raamat. Traducción de Aita kurfeldt.

\section{Traducciones al farsi:}

- Nazarin. 2001. Teherán: Amir Kabir Publisher.

- Doña Perfecta. 2002. Editorial z-provisional.

- Doña Perfecta. 2011. Editorial z-provisional.

- Doña Perfecta. 2015. Editorial z-provisional. 


\section{Traducciones al finés:}

NOVELAS

- Marianela. 1921. Helsinki: Otava. Traducción de Joel Lehtonen.

\section{Traducciones al francés:}

NOVELAS

- Doña Perfecta. 1884. Florencia: Revue Internationale II, III. Traducción de Julien Lugol.

- Marianela. 1884. París: Librairie Hachette et Cie. Traducción de A. Germond de Lavigne.

- Doña Perfecta. 1885. París: E. Giraud et Cie. Éditeurs. Nouvelle Librairie Parisienne. Prólogo de Albert Savine. Traducción de Julien Lugol.

- Doña Perfecta. 1885. París: Librería Hachette. Traducción de Julien Lugol.

- Marianela. 1885. Florencia: Revue Internationale VII. Traducción de Julien Lugol.

- Marianela. 1886. París: Les heures du salon et de l'atelier. Traducción de Julien Lugol.

- El amigo Manso. 1887. París: Librería Hachette. Traducción de Julien Lugol.

- Marianela. 1888. París: H. Noirot. Petite Bibliothèque Universelle. Traducción de Julien Lugol.

- Marianela. 1898. París: Librairie des Publications à 5 Centimes. Traducción de Julien Lugol.

- Misericordia. 1899-1900. París: Le Temps, feuilleton. Traducción de Maurice Bixio.

- Misericordia. 1900. París: Hachette. Prólogo de B. Pérez Galdós. Prefacio de Morel - Fatio. Traducción de Maurice Bixio.

- Doña Perfecta. 1904. París: Cosmópolis. Traducción de Julien Lugol.

- Marianela. 1907. Ginebra: Editions Atar. Traducción de Marguerite Gascard.

- Misericordia. 1913. París: Thomas Nelson and Sons. Prólogo de Benito Pérez Galdós. Prefacio de Morel-Fatio. Traducción de M. Bixio.

- Marianela. 1949. Toulouse: Privat; París: Didier. Classiques Spagnols Privat. Traducción de H. Fitte.

- Misericordia. 1956. París: Club Bibliophile de France. Traducción de Emma H. Clouard.

- Nazarín. 1962. París: Éditions Rencontre. Traducción de Georges Haldas.

- Doña Perfecta. 1963. París: Les Éditeurs Français Réunis. Introducción de María Pérez Galdós. Prefacio de Max Aub. Traducción de Robert Marrast.

- Misericordia. 1964. París: Les Éditeurs Français Réunis. Traducción de Pierre Genoun.

- Miau. 1968. París: Les Éditeurs Français Réunis. Prefacio de M. Tuñon de Lara. Traducción de Jean Marey. 
- Tristana. 1972. París: Aubier-Flammarion. Bilingüe. Traducción de Suzanne Raphael.

- La Fontana de Oro. 1975. Lausana: Éditions Rencontre. Traducción de Bernard Lesfarques.

- L'ami Mansu. [El amigo Manso]. 1975. Lausana: Éditions Rencontre; París: Éditeurs Francais Réunis. Traducción de Pierre Guenoun.

- Madame Bringas. 1975. [La de Bringas]. Lausana: Éditions Rencontre; París: Éditeurs Francais Réunies. Traducción de Pierre Guenoun.

- Fortunata y Jacinta. 1975. París: Les Éditeurs Français Réunis. Traducción de Monique Morazé; Robert Marrast.

- Nazarín. 1975. París: Éditeurs Francais Réunis. Traducción de George Haldas.

- Nazarín. 1976. París: Editor Monique Morazé. Prefacio de George Haldas. Traducción de Antoinette de Montmollin.

- Fortunata et Jacinta. 1980. [Fortunata y Jacinta]. París: Les Éditeurs Francais Réunis. Traducción de Monique Morazé; Robert Marrast.

- Tristana. 1992. París: GF-Flammarion. Notas de Sidi Lakdari. Traducción de Suzanne Raphael.

- Misericordia. 1995. París: J. Losfeld. Traducción de Emma H. Clouard.

- La passion Torquemada. I Tourments. 1995. [Torquemada en la hoguera. Torquemada en la Cruz]. París: Desjonquères. Traducción de Caroline Pascal.

- La passion Torquemada. II Purgatorio. 1995. [Torquemada en el Purgatorio]. París: Desjonquères. Traducción de Caroline Pascal.

- Torquemada et Saint Pierre. III. 1998. [Torquemada y San Pedro]. París: Desjonquères. Traducción de Lilianne Hasson.

- La déshéritée. (Chapitre I, II, III, IV). 2008. [La desheredada]. Madrid: Isidora. Revista de Estudios Galdosianos, n. ${ }^{\circ}$ 8, pp.193-214. Traducción de Daniel Gautier

- La déshéritée. 2009. [La desheredada]. Madrid: Isidora Ediciones. Traducción de Daniel Gautier.

- Miau. 2010. Madrid: Isidora Ediciones. Traducción de Daniel Gautier.

- Gloria. 2012. Madrid: Isidora Ediciones. Traducción de Daniel Gautier.

- Halma. Nazarín. 2012. Madrid: Isidora Ediciones. Traducción de Claire Nicolle; Daniel Gautier.

- Réalitè. 2014. Madrid: Isidora Ediciones. Traducción de Daniel Gautier.

- Tristana. Tormento. 2014. Madrid: Isidora Ediciones. Traducción de Daniel Gautier.

- Los Torquemada. 2014. [Torquemada en la hoguera. Torquemada en el Purgatorio]. Madrid: Isidora Ediciones. Traducción de Daniel Gautier.

\section{Episodios nacionales}

- Soeur Marcela. 1901. [La campaña del Maestrazgo]. París: Le Temps, feuilleton. Traducción de La Grange de Langres; Arbellán; Agulo. 
- Le roman de Soeur Marcela. 1902. [La campaña del Maestrazgo]. París: CalmannLévy, Editores. Traducción de La Grange de Langres.

- Guerrilleros. 1904. [Juan Martín el Empecinado]. Revue de Paris, XI, n. o 2, 3, pp. 225-253, 580-614. Traducción de Xavier de Cardaillac.

- L'escadre hérö̈que. La révolte. 1952. [Trafalgar. El 19 de marzo y el 2 de mayo]. París: Club Bibliophile de France. Traducción de Francis de Miomandre; Jean Babelon.

- Trafalgar. La Cour de Charles IV. 1969. [Trafalgar. La Corte de Carlos IV]. París: Les Éditeurs Francais Réunis. Traducción de Monique Morazé; Bernard Sessé.

- Juan Martín el Empecinado. Les cent milles fils de Saint Louis. 1969. [Juan Martín el Empecinado. Los cien mil hijos de San Luis]. París: Éditions Rencontre. Traducción de Maurice Lacoste.

- Le 2 Mai 1808 suivi de Baylén. 2012. [2 de mayo. Bailén]. Nantes: Normant Jean-Ives Eds. Traducción de Claire- Nicolle Robin.

- Trafalgar. 2014. Madrid: Isidora Ediciones. Traducción de Daniel Gautier.

- Le 19 de mars et le de mai. 2014. [El 19 de marzo y el 2 de mayo]. Madrid: Isidora Ediciones. Traducción de Daniel Gautier.

- La Cour de Carlos IV. 2014. [La Corte de Carlos IV]. Madrid: Isidora Ediciones. Traducción de Daniel Gautier.

- Bailén. 2014. Madrid: Isidora Ediciones. Traducción de Daniel Gautier.

- Napoleón à Chamartín. 2014. [Napoleón en Chamartin]. Madrid: Isidora Ediciones. Traducción de Daniel Gautier.

- Saragosse. 2014. [Zaragoza]. Madrid: Isidora Ediciones. Traducción Daniel Gautier.

- Gérone. 2014. [Gerona]. Madrid: Isidora Ediciones. Traducción Daniel Gautier.

- Cadix. 2014. [Cádiz]. Madrid: Isidora Ediciones. Traducción Daniel Gautier.

- Juan Martín L'Empecinado. 2014. [Juan Martín el Empecinado]. Madrid: Isidora Ediciones. Traducción de Daniel Gautier.

- La bataille des Arapiles. 2014. [La batalla de los Arapiles]. Madrid: Isidora Ediciones. Traducción de Daniel Gautier.

\section{TEATRO}

- Electra. París: 1904. Adaptación de Paul Milliet.

- Le grand père. 2013. [El abuelo]. Madrid: Isidora Ediciones. Traducción de Daniel Gautier.

\section{Cuentos}

- La conjuration des mots. 2005. [La conjuración de las palabras]. Madrid: Isidora. Revista de Estudios Galdosianos, n. ${ }^{\circ}$ 2, pp. 231-238. Ilustrador: Benoît Vieillard. Traducción de Pierre Audureau. 
- La plume dans le vent ou le voyage de la vie. 2007. [La pluma en el viento]. Madrid: Isidora. Revista de Estudios Galdosianos, n. ${ }^{\circ}$ 4, pp. 171-176. Traducción de Pierre Audureau.

- Une industrie qui se nourrit de la mort; l'episode musical du choléra. 2012. [Una industria que vive de la muerte; episodio musical del cólera]. Madrid: Isidora, Revista de Estudios Galdosianos n. ${ }^{\circ}$ 19, pp. 178-190. Traducción de Sonia Gómez Urbina; Alejandro González Domínguez.

\section{Traducciones al gallego:}

EPISODIOS NACIONALES

- O 19 de marzo e o 2 de maio. 2011. [El 19 de marzo y el 2 de mayo]. Vigo, Pontevedra: Trymar. Traducción de Pablo María Morell González.

\section{Traducciones al griego:}

\section{NOVELAS}

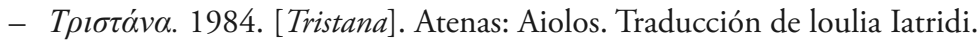



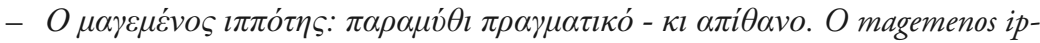
potis: Paramythi pragmatiko...ki apithano $O$ magemenos ippotis: Paramythi pragmatiko...ki apithano 2000. [El caballero encantado]. Atenas: Kastaniotis. Traducción de Vasilis Latridis.

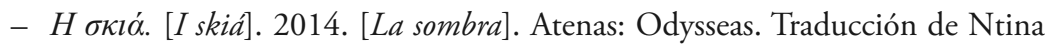
Zampethay.

- Nióov. [Miaou]. 2018. [Miau]. Atenas: Vakchikon. Traducción de Tasos Psarris.

\section{Traducciones al hebreo:}

NOVELAS

- הליהת [Gloria]. 2012. Ramat Gan: Rimonim. Traducción de Menahem Argov; Rosi Burakoff.

- Doña Perfecta. 2013. Tel Aviv: Am Oved Publishers LTD. Traducción de Moshe Ron.

\section{Traducciones al húngaro:}

NOVELAS

- Gloria. 1881. Budapest. Traducción de Nagy Istvan.

- Misericordia. 1900. Budapest. Traducción de Arthur Hegedü.

- Doña Perfecta. 1903. Budapest. Traducción de Hussar Vilnos.

\section{EPISODIOS NACIONALES}

- Zaragoza. 1954, 1957. Budapest. Traducción de Szanz Bela; Zórad Ernó Rajzaival. 
- Cádiz. 1984. Budapest: Európa. Traducción de Tünde Halász.

\section{Traducciones al inglés-Reino Unido:}

NOVELAS

- Gloria. 1879. Londres: Remington and Co. Traducción de Natham Wetherell.

- Gloria. 1883. Londres: Trübner \& Co. [2 vols.]. Revised and corrected by William S. Gottsberger. Traducción de Clara Bell.

- Doña Perfecta, a Tale of Modern Spain. 1886. [Doña Perfecta]. Londres: Samuel Tinsley. Traducción de D. P. W.

- Marianela. 1893. Londres: Digby, Long. Traducción de Mary Wharton.

- Doña Perfecta. 1894. Londres: The Fisher Unwin. Traducción de Mary Wharton.

- The Spendthrifts. 1951. [La de Bringas]. Londres: Weidenfeld \& Nicolson. The Illustrated Novel Library. Ilustraciones de Charles Mozley. Traducción de Gamel Woolsey.

- Torment. 1952. [Tormento]. Londres: Weidenfield \& Nicolson. Ilustraciones de Charles Mozley. Traducción de J.M. Cohen.

- The Spendthrifts. 1953. [La de Bringas]. Londres: Reader's Union. Ilustraciones de Charles Mozley. Traducción de Gamel Woolsey.

- Miau. 1963. Londres: Methuen. Traducción de J. M. Cohen.

- Fortunata and Jacinta: Two Stories of Married Women. 1973. [Fortunata y Jacinta]. Harmondsworth: Penguin Books. Traducción de Lester Clarck.

- La desheredada. 1976. Londres: The Folio Society. Traducción de Lester Clarck.

- Torquemada on the Fire. 1985. [Torquemada en la hoguera]. Glasgow: University of Glasgow. Traducción de Nicholas Round.

- Fortunata and Jacinta. 1987. [Fortunata y Jacinta]. Londres: Viking. Traducción de Agnes Moncy Gullón.

- Torquemada. 1988. Londres: André Deutsch. Traducción de Frances M. López-Morillas.

- Fortunata and Jacinta. 1992. [Fortunata y Jacinta]. Cambridge: Cambridge University Press. Traducción de Harriet S. Turner.

- Nazarin. 1993. Oxford: OUP. Traducción de Jo Labanyi.

- Misericordia. 1995. Santry: Dedalus. Traducción de Charles de Salis.

- That Bringas Woman: The Bringas Family. 1996. [La de Bringas]. London: Phoenix. Traducción de Catherine Jagoe.

- Tristana. 1996. Londres: Bristol Classical Press. Edición, introducción, notas y bibliografía by Gordon Minter.

- Fortunata and Jacinta. 1998. [Fortunata y Jacinta]. Londres: Penguin Books. Traducción de Agnes Moncy Gullón.

- Inferno. 1998. [Tormento]. Londres: Phoenix House (Weidenfeld \& Nicolson). Edición y traducción de Abigail Lee Six. 
- Tristana. 1998. Londres: Duckworth Publishers. Edición, introducción, notas y bibliografía de Gordon Minter.

- Tristana. 1998. Londres: Bloomsbury Publishing. PLC. Gordon Minter.

- Doña Perfecta 1999. Londres: Weidenfeld \& Nicolson Ltd. Traducción de A. K. Tulloch.

- Doña Perfecta. 2009. Oxford: Oxbow Books. Traducción de Graham Whittaker.

- Misericordia. 2007. Madrid. Isidora. Revista de Estudios Galdosianos, n. o 3, pp. 6-293. Traducción de Robert H. Russell.

- Misericordia. 2013. Madrid: Ediciones. Traducción de Robert Russell.

- Halma. 2015. Cambridge: Cambridge Scholars. Publishing. Traducción de Robert S. Rudder; Ignacio López-Calvo.

- Tristana. 2016. Mánchester: Manchester University Press. Traducción de Pablo Valdivia.

\section{EPISODIOS NACIONALES}

- Trafalgar. 1905/1921. Cambridge: Cambridge at the University Press. Edición, notas e introducción de F. A. Kirkpatrick.

- Trafalgar. 1951. Cambridge: Cambridge University Press. Traducción de Frederick Alexander Kirkpatrick.

TEATRO

- Meow. A Tragicomedy. 2014. [Miau]. Liverpool: Aris \& Phillips Hispanic Classics. Introducción y traducción de Ruth Katz Crispin.

Cuentos

- The Conspiracy of Words. 2007. [La conjuración de las palabras]. Madrid: Isidora. Revista de Estudios Galdosianos, n. 4, pp. 165-170. Traducción de Robert H. Russell.

\section{Inglés-EE. UU.:}

NOVELAS

- Gloria. 1882. Nueva York: William S. Gottsberger, Publisher. Traducción de Clara Bell.

- Doña Perfecta. 1883/1884. Nueva York: Gottsberger. Traducción de Clara Bell.

- Doña Perfecta. 1883. Nueva York: George Munro, Publisher. Traducción de D. P. W.

- Marianela. 1883. Nueva York: Willian S. Gottsberger, Publisher. Traducción de Clara Bell.

- La familia de León Roch. 1888. Nueva York: Willian S. Gottsberger, Publisher. Traducción de Clara Bell.

- Marianela: A Story of Spanish Love. 1892. [Marianela]. Chicago: A.C. McClurg and Company. Traducción de Hellen W. Lester. 
- Doña Perfecta. 1895. Nueva York: Harper \& Brothers Publishers. Introducción de W. Dean Howells. Traducción de Mary Jane Serrano.

- Doña Perfecta. 1897/1900. Boston and Londres: Ginn \& Company. Introducción y notas de A. R. Marsh.

- Doña Perfecta. 1900. Nueva York: P. F. Collier \& Son.

- Doña Perfecta. 1940. Nueva York: P. F. Collier \& Son circa.

- The Spendthrifts. 1952. [La de Bringas]. Nueva York: Farrar Straus \& Young. The Illustrated Novel Library. Ilustraciones de Charles Mozley. Traducción de Gamel Woolsley.

- Doña Perfecta. 1960. Hauppauge, NY: Barron’s Educational Series, Inc. Traducción de Harriet de Onís.

- Tristana. 1961. Peterborough, NH: R. R. Smith. Traducción de R. Selden Rose.

- Compassion. 1962. [Misericordia]. Nueva York: Frederick Ungar Publishing Co. Traducción de Toby Talbot.

- El amigo Manso. 1963. Nueva York: Oxford University Press. Edición de Denah Lida.

- Miau. 1970. Nueva York: Oxford University Press. Traducción de Eduard R. Mulvihill; Roberto G. Sánchez.

- León Roch: a Romance. 1974. [La familia de León Roch]. Nueva York: Howard Ferting. Traducción de Clara Bell.

- The Shadow. 1980. [La sombra]. Athens, Ohio: Ohio University Press. Traducción de Karen O. Austin.

- Fortunata and Jacinta: Two Stories of Married Women. 1986. [Fortunata y Jacinta]. Athens, GA: University of Georgia Press. Traducción de Agnes Moncy Gullón.

- Torquemada. Torquemada at the Stake - Torquemada on the Cross - Torquemada in Purgatory - Torquemada and Saint Peter. 1986. [Torquemada en la hoguera. Torquemada en la Cruz. Torquemada en el Purgatorio. Torquemada y San Pedro]. Nueva York: Columbia University Press. Traducción de Frances M. LópezMorillas.

- The Golden Fountain Cafe: a Historic Novel of the XIXth Century. 1989. [La Fontana de Oro]. Pittsburgh, PA: Latin American Literary Review Press. Traducción de Walter Rubin et al.

- Our Friend Manso. 1987. [El amigo Manso]. Nueva York: Columbia University Press. Traducción de Robert Russell.

- Ángel Guerra. 1990. Lewiston, NY: Edwin Mellen Press. Traducción de Karen O. Austin.

- The Unknown. 1991. [La incógnita]. Lewiston, NY: Edwin Mellen Press. Traducción de Karen O. Austin.

- Reality. 1992. [Realidad]. Lewiston, NY: Edwin Mellen Press. Traducción de Karen O. Austin. 
- The Cape of Don Francisco Torquemada: 1. Torquemada in the Bonfire. 2. Torquemada on the Cross. 3. Torquemada in Purgatory. 4. Torquemada and Saint Peter. 1996. [Torquemada en la hoguera. Torquemada en la Cruz. Torquemada en el Purgatorio. Torquemada y San Pedro]. San Bernardino, CA: Borgo Press. Traducción de Robert G. Trimble.

- Nazarín. 1997. Pittsburgh: PA: Latin American Literary Review Press. Traducción de Robert S. Ruder; Gloria Chacón de Arjona.

- Torquemada at the Stake. 2004. [Torquemada en la hoguera]. Mineola, Nueva York: Dover. Traducción de Stanley Appel Baum.

- Dona Perfecta. 2009 [Doña Perfecta]. ReadHowYouWant Publisher. Easy Read Edition.

- Gloria. 2012. Miami: Editorial Rarebooksclub.com. Traducción de N. Wetherell.

- Doña Perfecta. 2013. Miami: Editorial Rarebooksclub.com. Traducción de D. P. W.

- Marianela. 2013. Miami: Editorial Rarebooksclub.com

- The Spendthrifts. 2013. [La de Bringas]. Miami: Editorial Rarebooksclub.com

- Tristana. 2014. Review Book Classics. Nueva York: Editorial ReadHowYouWant. Traducción de Margaret Jull Costa.

- Dona Perfecta. 2014. [Doña Perfecta]. United States: Independent PublishinPlatform.

- Halma. 2010. Volume 69. Charleston: Nabu Press.

- Marianela. 2015. Scholar's Choice Publisher. Traducción de Mary Wharton.

- Misericordia. 2017. Miami: Editorial Rarebooksclub.com.

- Benito Pérez Galdós. Best Novels. 2017. Miami: Editorial Rarebooksclub.com. Traducción de Mary J. Serrano.

- Leon Roch: a Romance. Volume 1. 2018. [La familia de León Roch]. Franklin Classics Trade Press.

\section{EPISODIOS NACIONALES}

- Trafalgar. A Tale.1884. Nueva York: William S. Gottsberger Publisher. Traducción de Clara Bell.

- The Court of Charles IV. A Romance of the Escorial. 1886. [La Corte de Carlos $I V]$. Nueva York: William S. Gottsberger Publisher. Traducción de Clara Bell.

- La batalla de los Arapiles. 1895. Filadelfia: J.B. Lippincott. Traducción de R. Ogden.

- Saragossa. A History of Spanish Valor. 1899. [Zaragoza]. Boston: Little, Brown and Company. Traducción de Minna Caroline Smith.

- The Campaign of the Maestrazgo. 1990. [La campaña del Maestrazgo]. Wakefield. N.H.: Longwood Academic. Traducción de Lila Wells Guzmán.

- Trafalgar: a Tale. 1993. [Trafalgar]. Nueva York: H. Fertig. 
- Gerona. 1993. Lewiston, NY: Edwin Mellen Press. Traducción de G. J. Racz.

- A Royalist Volunteer. 1993. [Un voluntario realista]. Lewiston, NY: Edwin Mellen Press. Traducción de Lila Wells Guzmán.

- Juan Martin el Empecinado. 2009. Charleston: BiblioLife.

- El Grande Oriente. 2009. Charleston: Nabu Press.

- Aita Tettuaen. 2009. Miami: Editorial Rarebooksclub.com.

- The Court of Charles IV. 2009. [La Corte de Carlos IV]. Miami: Editorial Rarebooksclub.com. Traducción de Clara Bell.

- Saragossa. 2015. [Zaragoza]. Miami: Editorial Rarebooksclub.com. Traducción de Minna Smith.

- Gerona. 2015. Scholar's Select. Palala Press. Goodreads.

- Trafalgar. 2016. Miami: Editorial Rarebooksclub.com.

\section{TEATRO}

- The Grandfather. Drama in five acts. 1910. [El abuelo]. Boston: Poet Lore XXXI, no. 3. Traducción de Elizabeth Wallace.

- Electra. 1911. Chicago: The Drama, no. 2, pp. 12-138.

- Electra. 1919. Boston: R. G. Badger. En Contemporary Spanish Dramatists. Traducción de Charles Alfred Turrell.

- The Duchess of San Quintín, Daniela. 1928. [La de San Quintin]. En Masterpieces of Modern Spanish Drama. Nueva York-Londres: D. Appleton and Company. Traducción de Eleanor Bontecou; P. M. Hayden; J. G. Underhill.

- Marianela. 2014. Texas. Teatro Stone Cottage. Adaptación de Mark-Brian Sonna.

- The Duchess of San Quintin: a play in three acts. 2016. [La de San Quintín]. Newark: Juan de la Cuesta Cop. Traducción de Robert M. Fedorcheck.

- The Grandfather. Drama in Five Acts. 2017. [El abuelo]. Miami: Editorial Rarebooksclub.com.

\section{Traducciones al italiano:}

\section{NOVELAS}

- La fontana d'oro. 1874. [La Fontana de Oro] Milán: Fratelli Treves. Traducción de Federico Pozzani.

- La fontana d'oro. 1878. Milán: La Ragione. Giornale della democrazia (folletín). Traducción de Eugenio Fabris.

- La fontana d'oro. 1879. Nápoles: IL Pungolo. Nápoles. Traducción de Eugenio Fabris.

- Marianella. 1880. [Marianela]. Bolonia: Tip. Pontificia. Mareggiani. Traducción de G. Demichelis.

- La famiglia di Leone Roch. 1883. [La familia de León Roch]. La Perseveranza. Giornale del mattino (folletín). Traducción de Daniele Rubbi. 
- La fontana d'oro. 1890. Milán: Fratelli Treves. Traducción de G. Demichelis.

- Donna Perfetta. 1892. La Perseveranza. Giornale del mattino (folletín). Traducción de Irma Ríos.

- La signora Perfetta. 1894. [Doña Perfecta]. Bari: Corriere delle Puglie (folletín). Traducción de G. C. Bernardi (Diana D’Alteno).

- Donna Perfetta. 1897. [Doña Perfecta]. Milano: Fratelli Treves.

- La fontana d'oro. 1900. [La Fontana de Oro]. Milán: Treves. Traducción de Federico Pozzani.

- Gloria. 1901. Florencia: R. Bemporad \& Figlio. Librai-Editori. Traducción de Italo Argenti.

- Sicut Christus. 1902. [Nazarín]. Florencia: G. Nerbini, Editore. Traducción de Guido Rubetti; José León Pagano.

- Marianela e Trafalgar. 1907. Milán: Fratelli Treves, Editori.

- Gli Occhi Uccidono. 1925. [Marianela]. Milán: Casa Editrice Pro Familia.

- Fortunata e Giacinta. Stria di due donne maritate. 1926. [Fortunata y Jacinta]. Florencia: Adriano Salami, Editore. Traducción de Silvia Baccani Giani.

- Misericordia: scene di vita madrilena. 1929. [Misericordia]. Turín: Cosmopolitan. Traducción de Camilo Berra.

- Misericordia. 1954. Turín: Unione Tipografico-Editrice Torinense. Traducción de Camilo Berra.

- Misericordia. 1956. Milán: Rizzoli. Traducción de Antonio Gasparetti.

- Tristana. 1970. Milán: Adelphi. Traducción de Italo Alighiero.

- Misericordia. 1970. Milán: Fabbri. Traducción de Gabriele Morelli.

- Misericordia. 1971. Florencia: Vallecchi. Traducción de Antonio Gasparetti.

- Tristana. 1975. Milán: Oscar Mondadori. Traducción de Italo Alighiero.

- Misericordia. 1982. Turín: UTET. Traducción de Camilo Berra.

- Tristana. 1991. Milán: Oscar Mondadori. Traducción de Italo Alighiero.

- Tristana. 1991. Venecia: Marsilio. Introduzione de Vito Galeotta. Traducción de Augusto Guarino.

- Misericordia. 1991. Milán: Garzanti. Introducción, traducción y notas de David Urman.

- Tristana. 1992. Milán: Garzanti. Traducción e introducción de Irina Bajini.

- La donna di denari. 1993. [La de Bringas]. Milán: Frassinelli. Prefacio de Ángela Bianchini. Traducción de Elena Clementelli.

- L’Ombra. 1994. [La sombra]. Lecce: Argo, cop. Traducción de Augusto Guarino.

- Tristana. 1999. En Tre donne galdosiane. Urbino: Rocco. Traducción de Alfredo Rocco. 
- Nazarín. 2004. Roma: Avagliano. Traducción de Lucio Sessa; Bruno Quaranta.

- Tristana. 2004. Roma: Editoriale L'Expresso. Traducción de Francesco Guazzelli.

- Tormento. 2006. Cava de Tirreni: Marlin Editore. A cargo de M. R. Alfani. Traducción de U. Castaldi; R. Duccillo; S. Vitale.

- Tristana. 2007. Venecia: Marsilio. Traducción de Augusto Guarino.

- Realtá. 2009. [Realidad]. Madrid: Isidora Ediciones. Traducción de Sagrario del Río.

- L'amico Manso. 2010. [El amigo Manso]. Atripalda, AV: Mephite. Traducción de Lucio Sessa.

- Doña Perfecta. 2011. Atripalda, AV: Mephite. Traducción de Lucio Sessa.

- La disederata. 2011 [La desheredada]. Madrid: Isidora Ediciones. Traducción de Assunta Polizzi.

- Marianela. 2012. Nápoles: Liguori. Traducción de Laura Silvestri.

- Donna Perfecta. 2014. [Doña Perfecta]. Savona: Ed. Pentagora. Traducción de F. Toso.

- Lincognita. 2018. [La incógnita]. Roma: Theoria. Traducción de Laura Silvestri.

\section{EPISODIOS NACIONALES}

- Trafalgar. 1907. Milán: Fratelli Treves. Traducción de G. D. Michelis.

- Gerona. 1944. Milán: Valentino Bompiani \& C. Prefacio: A. R. Ferrarin. Traducción de A. R. Ferrarin.

- Trafalgar. 2008. Roma: La Nuova Frontiera. Traducción de G. Gentile.

- Cadice: romanzo. 2014. [Cádiz]. Tropea, Calabria: Meligrana. Traducción de Eleonora Demarzo.

- L'equipaggio del re Josè. 2015. [El equipaje del rey José]. Tropea: Meligrana. Traducción de Eleonora Demarzo.

- Amedeo I. 2015. [Amadeo I]. Lecce: Pensa Multimedia. Traducción de Antonio Boccardo; Diego Símini.

\section{TEATRO}

- Electra. 1901. Roma. Compañía Mauri. Traducción de Enrique Tedeschi.

- Tristana.1998. Bolonia: Teatro del Navile. Compañía Trame Perdute. Traducción y dirección de Giuseppe Liotta.

- Il Nonno. [s.d.] [El abuelo]. Commedia drammatica in cinque atti. Florencia: Casa Editrice Nemi. Traducción de Gilberto Beccari.

- Alceste. 2010. Roma: Nuova Cultura Edizione. Traducción de Trinis Antonietta Messina Fajardo. Adaptación texto de Giuseppe Orilli. 


\section{Cuentos}

- Le città italiane. 1993. [Viaje a Italia]. Napoli: A Guida. Traducción de Vito Cardone.

- Racconti fantastici. 2006. [Cuentos fantásticos]. Roma: Donzelli Editore. A cura de María R. Alfani. Traducción de Ugo Castaldi; Domenico D’Amiano; Roberta Duccillo; Salvatore Vitale.

- La congiura delle parole. 2007. [La conjuración de las palabras]. Madrid: Isidora. Revista de Estudios Galdosianos, n.o 5, pp. 191-196. Traducción de Silvia di Persio.

- Il romanzo nel tram. 2010. [La novela en el tranvía]. Edición: Cento Autori. Traducción de Tiziana Affinito.

\section{Traducciones al japonés:}

NOVELAS

- Marianera. 1993. [Marianela]. Tokio: Sairyûsya. Traducción de Abe Kôzi.

- Horutounata to Hasinta (1) 1998. [Fortunata y Jacinta]. Tokio: Suiseisya. Traducción de Asanuma Kiyosi.

- [La conjuración de las palabras]. 2005. Madrid: Isidora. Revista de Estudios Galdosianos, n. ${ }^{\circ}$ 2, pp. 219-224. Traducción de Ranko Hiraok.

- Doña Perfecta. 2015. Tokio: Gendaikikakushitu. Traducción de Eizo Ogusu.

\section{Traducciones al malabar:}

\section{TEATRO}

- Los Condenados. 2013. Miami: Editorial Rarebooksclub.com

\section{Traducciones al neerlandés:}

\section{NOVELAS}

- Dona Perfecta. 1883. Leiden: E. G. Brill. Traducción de M. A. de Goeije.

- Marianela. 1890. Leiden: A. H. Adriani.Traducción de Una.

- Leon Roch en familie. 1891. [La familia de León Roch]. Leiden: A. H. Adriani. Traducción de P. du Buy.

- Tristana. 1974. Ámsterdan: Uitgeverij de Arbeiderspers. Traducción de Robert Lemm.

- Miau. 1979. Wijnegem: Het Spectrum. Epílogo y traducción de Roelof G. Groeneboer.

- Marianela. 1998. Leiden: Menken Kasander \& Wigman Uitgevers. Traducción de Elly Bovée.

- Fortunata en Jacinta: het verhaal van twee echtgenotes. [Fortunata y Jacinta]. 2000. Leiden: Menken Kasander \& Wigman. Traducción de Adri Boon.

- Mevrouw Bringas. 2001. [La de Bringas]. Leiden: Menken Kasander \& Wigman. Traducción de Elly Bovée. 
- Tormento. 2001. Leiden: Menken Kasander \& Wigman. Traducción de Adri Boon.

- Miauw. 2002. [Miau]. Leiden: Menken Kasander \& Wigman. Traducción de Adri Boon.

- Mededogen. 2004. [Misericordia]. Leiden: Menken Kasander \& Wigman. Traducción de Frans Oosterholt.

EPISODIOS NACIONALES

- Zuster Marcela. Roman eener Non. 1903. [La campaña del Maestrazgo]. Leiden: A. H. Adriani.

\section{TEATRO}

- Electra. 1901. Leiden: A. H. Adriani. Traducción de Michael A. de Goeje.

\section{Cunntos}

- «De Roman in de Tram». 1959. [La novela en el tranvía]. Utrecht: Prisma-Het Spectrum. En Luis de Castresana (ed.) Spaanse verhalen, pp. 16-35. Traducción de G. Evenhuis.

\section{Traducciones al noruego:}

\section{NOVELAS}

- Fortunata og Jacinta. 1998. [Fortunata y Jacinta]. Oslo: Aschehoug. Traducción de Kari Risvik; Kjell Risvik.

\section{Traducciones al polaco:}

NOVELAS

- Donia Perfecta. 1952. [Doña Perfecta]. Varsovia: Ksiaska i Wiedza. Traducción de Edward Martuszewski.

- Gloria. [s. d.]. Cracovia: Przeglad Powszechny.

- La desheredada. [s. d.]: Cracovia. Przeglad Powszechny.

- Nazarín. [s. d.]. Cracovia: Przeglad Powszechny.

- Torquemada y San Pedro. [s. d.]. Cracovia. Przeglad Powszechny.

- Zlota Fontana. 1961. [La Fontana de Oro]. Varsovia: P.I.W. Casa Editorial del Estado. Traducción de Zofía Szleyen.

- Zjawa. 1978. [La sombra]. Cracovia: Wydawnictwo Literackie. Traducción de Jadwiga Konieczna-Twardzikowa.

- Misericordia. 1985. Cracovia: Wydawnictwo Literackie. Traducción de Zofia Szleyen.

- Zjawa. 1991. [La sombra]. Varsovia: Reporter. Traducción de Jadwiga Konieczna-Twardzikowa.

- Tristana. 2011. Varsovia: Sagittarius. Traducción de Maksymilian Gratz. 


\section{EPISODIOS NACIONALES}

- Saragossa. 1955. [Zaragoza]. Varsovia: Czytelnik. Traducción de Kalina Wojciechowska; Z. Szleyen.

- Bitwa pod Arapilami. 1957. [Cádiz; La batalla de los Arapiles; Juan Martín el Empecinado]. Varsovia: Ed. Caytelnik. Introducción de Z. Szleyen. Traducción de Kalina Wojciechowska; Kalina Wojciechwska; Zofia Szleyen.

\section{TEATRO}

- Casandra. 2013. Miami: Editorial Rarebooksclub.com

\section{Traducciones al portugués:}

NOVELAS

- As novelas de Torquemada. 1989. [Torquemada]. Río de Janeiro: Paz e Terra. Traducción de Claudia Schilling.

- Tristana. 1993. Lisboa: Teorema. Traducción de José Colaco Barreiros.

- Rosalía de Bringas. 2011. [La de Bringas]. San Pedro do Estoril: Saída de Emergencia. Traducción de José Manuel Lópes.

\section{TEATRO}

- Electra. 1901. Oporto: Librería Chardon de Tello \& Irmao, editores. Traducción de Ramalho Ortigao.

\section{Traducciones al rumano:}

NOVELAS

- Marianela. 1890. Bucarest: Democracia.

- Marianela. 1918. [Marianela]. Bucarest: Libraria Carmen-Sylva. Traducción de Leontin Iliescu.

- Doña Perfecta. 1965. Bucarest: Editura Pentru. Literatura Universala. Traducción, prefacio y notas de Andrei Ionescu.

- Benina. 1984. [Misericordia]. Bucarest: Universidad. Traducción de MaríaMagdalena Nicolae.

- Torquemada. 1984. Bucurest: Minerva. Traducción de Dumitru Radulian; Vasile Igna.

- Dezmostenita. 1990. [La desheredada]. Cluj-Napoca: Dacia. Traducción de Doina Lincu; Alexandru Lincu.

- Dragoste pierduta. 1996. [Tristana]. Bucarest: Minerva. Traducción de Alexandru Lincu.

- Doña Perfecta. 2005. Bucarest: Leda. Traducción de Andrei Ionescu.

\section{EPISODIOS NACIONALES}

- Zaragoza texte alese. 1967. [Zaragoza]. Bucarest: S. Edit. Estudio introductorio, notas y vocabulario de $M$. Rudreanu. 
- Episoade Nationale. 19 Martie si 2 mai. Bailen. 1968. [Episodios Nacionales. El 19 de marzo y 2 de mayo. Bailén]. Bucarest: Editura Pentru Literatura Universala. Traducción y comentarios de Andrei Ionescu.

- Saragoza. 1969. [Zaragoza]. Bucarest. Editura Pentru Literatura Universala. Traducción de Ciresica Dimitriu.

- Trafalgar. 2004. Iasi: Cronica. Traducción de Aurica Bradeanu; Ligia Bradeanu.

\section{Traduciones al ruso:}

\section{NOVELAS}

- [El audaz]. 1879. San Petersburgo: Dielo.

- Золотой фонтан. [La Fontana de Oro]. 1881. San Petersburgo: Zagranichniy vestnik.

- Донья Перфекта [Doña Perfecta]. 1882. San Petersburgo. Traducción de María Watson.

- Мильий Мансо. 1883. [El amigo Manso]. San Petersburgo: Vestnik Evropi. Traducción de Isaac Pavlovsky.

- [El audaz]. 1884. San Petersburgo: Dielo.

- Донья Перфекта. [ Doña Perfecta]. 1911. San Petersburgo. Traducción de María Watson.

- Очарованный кавальеро Ocharovanni Kabaliere. 1923. [El caballero encantado]. Moscú. Traducción de B. Krzhevsky.

- Очарованный кавальеро. Ocharovanni Kabaliere. 1927. [El caballero encantado]. Leningrado: Priboi. Introducción y traducción de B. Krzhevsky.

- Донья Перфекта. Donya Perfekta. 1935. [Doña Perfecta]. Leningrado: Khud, Lit. Introducción y traducción de D. Vygodsky.

- Золотой фонтан. Zolotoi Fontan. 1937. [La Fontana de Oro]. Leningrado: Goslitizdat. Traducción de V. V. Rakhmanov.

- Очарованный кавальеро. [El caballero encantado]. 1940. Moscú.

- Донья Перфекта. Don' a Perfekta. 1952/1956. [Doña Perfecta]. Moscú: Judozestvennoj Literatury. Prólogo de K. B. Zurinev. Notas de M. ${ }^{a}$ Luisa González. Traducción de Skyni Vafa; Boris Anatol' evich Starostin.

- Торквемада на костре. Торквемада на кресте. Торквемада в чистилище. Торквемада и святой Пётр: Пер. с исп. Москва: Гослитиздат. 1958. (Повести о ростовщике Торквемаде). Poviesti o rostobstike Torquemada. Torquemada no kostrie. Torquemada na krieste. Torquemada $b$ chistiliste. Torquemada i sbiatei. Pietr. [Torquemada en la hoguera. Torquemada en la Cruz. Torquemada en el Purgatorio. Torquemada y san Pedro]. Moscú: Goslitisdat. Isdatielstvo Judosiestviennoe Literaturii.

- Донья Перфекта. [Doña Perfecta]. 1964. Moscú: Editorial «Enseñanza Superior». Prólogo de K. B. Zurinev. Comentarios en español de M a Luisa González. Traducción de Skyni Vafa; Boris Anatol'evich Starostin. 
- Мильій Мансо. [El amigo Manso]. 1971. Moscú: Judosiestviennia Literatura.

- Тристана; Назарин; Милосердие. [Tristana. Nazarín. Miloserdie]. 1987. [Tristana. Nazarín. Misericordia]. Leningrado: Judosiestviennia Literatura. Introducción y crítica de Zacarías Plavskin. Traducción de Gueorgui Oriel; Vladímir Símenov; Vladímir Fiéderev.

- Обездоленная. 2013. [La desheredada]. Madrid: Isidora Ediciones. Traducción de Ekaterina Macías Pavelbea.

- Донья перфекта. Don'a Perfekta. 2014. [Doña Perfecta]. Madrid: Isidora Ediciones. Traducción de Ekaterina Macías Pavelbea.

- Реальность. 2014. [Real'nost]. [Realidad]. Madrid: Isidora Ediciones. Traducción de Ekaterina Macías Pavelbea.

- мяу. 2014. Mâu. [Miau]. Madrid: Isidora Ediciones. Traducción de Ekaterina Macías Pavelbea.

\section{EPISODIOS NACIONALES}

- [La segunda Casaca]. 1884. San Petersburgo: Dielo.

- Двор Карла IV. 1893. [La Corte de Carlos IV]. San Petersburgo: Tipografía A. S. Suvorin. Traducción de Ekaterina Umámetz.

- Двор Карла IV. Dvor Karla IV. 1895. [La Corte de Carlos IV]. San Petersburgo. Traducción de Ekaterina Umámetz.

- Ocada Capazoccbl. Osada Saragossy. 1896. [Zaragoza]. San Petersburgo: Tipografía A. S. Suvorin. TRAD.

- Ocada Capazoccbl. 1898. [Zaragoza]. San Petersburgo: Tipografía A.S. Suvorin.

- Trafalgar. 1908. San Petersburgo: Dielo

- Kaдикc. Kadika. 1938. [Cádiz]. Moscú: Goslitizdat. Introducción de F. Kelyin. Traducción de I. Gladkova; S. Volsky.

- Capazoccbl. Saragosa. 1938. [Zaragoza]. Moscú: Goslitizdat. Introducción de F. Kelyin. Traducción de S. S. Ignatón.

- Хуан Мартин эль Эмпесинадо. Khuan Martin, el Empesinado. 1940. [Juan Martín el Empecinado]. Moscú: Goslitizdat. Isdatielstvo Judosiestviennia Literatura. Introducción de F. Kelyin. Traducción de M. Gelfand.

- Tрафальгар: Повесть. Trafal'gar. 1961. [Trafalgar]. Moscú: Goslitizdat. Traducción de R. Pojlebkina.

- 19 марта и 2 мая; Байлен; Наполеон в Чамартине. 1972. [El 19 de marzo y el 2 de mayo. Bailén. Napoleón en Chamartín]. Moscú: Judosiestviennia Literatura.

- Хуан Мартин эль Эмпесинадо; Сражение при Арапилях. 1975. [Jиап Martín el Empecinado. La batalla de los Arapiles]. Moscú: Judosiestviennia Literatura.

- Жерона..Кадикс. 1975. [Gerona. Cádiz]. Moscú: Judosiestviennia Literatura. Prólogo y notas de D. Priskera. 
- Двор Карла IV. Золотой фонтан. 2018. [La Corte de Carlos IV. La Fontana de Oro]. Moscú: TERRA. Knizhnyi Klub Knigoviek.

\section{Traducciones al serbio:}

NOVELAS

- Doña Perfecta. 1952. Zagreb: Zora. Traducción de Gustav Krklec.

- Nazarín. 2006. Belgrado: Rad. Traducción de Aleksandra Mancic.

- Doña Perfekta. 2007. [Doña Perfecta]. Belgrado: Clio. Traducción de Bijana Isalovic Bukvic

- Tristana. 2007. Belgrado: Rad. Traducción de Aleksandra Mancic.

- Razbastinjena. 2012. [La desheredada]. Pirot: Pi-press. Traducción de Dalibor Soldatic.

\section{EPISODIOS NACIONALES}

- Trafalgar. 2008. Belgrado: Utopija. Traducción de Vladimir Ninkovic.

\section{Traducciones al suajili:}

EPISODIOS NACIONALES

- Los Ayacuchos. 2013. Miami: Editorial Rarebooksclub.com

\section{Traducciones al sueco:}

\section{NOVELAS}

- Doña Perfecta. 1893. Estocolmo: Fr. Skoglunds Forlag. Traducción de Karl August Hagberg.

- Marianela. 1894. Estocolmo: Skoglunds. Traducción de Augusta Hagberg.

- Tva hustrur: Fortunata och Jacinta. 1992. [Fortunata y Jacinta]. Estocolmo: Gidlunds. Traducción de Peter Landelius.

\section{Cuentos}

- Ordets Sammansvärjning Avdós. 2005. [La conjuración de las palabras]. Madrid: Isidora. Revista de Estudios Galdosianos, n. ${ }^{\circ}$ 1, pp. 169-174. Traducción de Justina Sánchez Prieto.

\section{OTRAS EDICIONES}

\subsection{Referencias bibliográficas incompletas}

En la «Introducción» del presente trabajo, señalábamos la posibilidad de encontrar obras traducidas de Galdós con pocos datos, entre otras razones por la consideración nada relevante del oficio del traductor a nivel social, aunque sí fueron estimados en el ámbito académico. Sin embargo, hoy nos parece importante citar estas obras que abren nuevas perspectivas en la investigación, tanto desde la vertiente de la traductología como 
desde la galdosiana. La mayoría de estas traducciones datan de finales del XIX o principios del XX y las localizamos principalmente en los países del este europeo.

\section{Búlgaro:}

- Capazoca [Zaragoza]. 1945. Sofía.

\section{Inglés-Reino Unido:}

- Misericordia. 1955. Gran Bretańa.

\section{Inglés-EE. UU.:}

- Marianela. 1902.

- Marianela. 1921.

- Marianela. 1926.

- Marianela. 1964.

\section{Polaco:}

- Donia Perfecta. 1887. [Doña Perfecta]. Varsovia.

- Marianela. 1889. Varsovia.

\section{Rumano:}

- Marianela. 1899. Bucarest.

- Gloria. [s. d.].

\section{Ruso:}

- Обездоленная. 1883. [La desheredada].

- Глориа. [Gloria]. 1884. San Petersburgo.

- Золотой фонтан. [La Fontana de Oro]. 1911. San Petersburgo.

- [La sombra]. [s. d.].

- [Marianela]. [s. d.].

- [Lo prohibido]. [s. d.]

- [Misericordia]. [s. d.]

- [Un voluntario realista]. 1879.

- Двор Карла IV. 1898. [La Corte de Carlos IV].

\subsection{Pérez Galdós en español}

Si atendemos al título del presente volumen, Traducción y recepción, y consideramos la traducción desde el punto de vista amplio de los estudios de la postraducción, que comentamos en la "Introducción» de este trabajo, no deberíamos obviar otras ediciones que reflejan el interés y la recepción de Pérez Galdós más allá de nuestras fronteras. Nos referimos a ciertos estudios y ediciones en departamentos de español tanto universitarios 
como en enseñanza secundaria; textos con introducciones y notas a cargo de eminentes profesores hispanistas y galdosianos. Llama la atención la cantidad de obras impresas, así como otras publicaciones que corresponden a las nuevas formas de edición, posiblemente como lectura de los numerosos hablantes hispanos, particularmente en EE. UU.

\section{Alemania:}

- La Fontana de Oro. 1872, 1883. Leipzig: F.A. Brockhaus. Colección de Autores Españoles, n. ${ }^{\circ} 31$.

- Marianela. 2008. Ismaning: Hueber Verlag. Nivel 3 (Book \& CD) (Lectura en español).

\section{Dinamarca:}

- Tristana. 1976. Copenhagen: Grafisk. En español

\section{Reino Unido:}

- Tormento. 1977. Oxford: Pergamon Oxford Spanish Series. Edición de J. Rodgers Eamonn.

- Tristana. 2013. Londres: Bloomsbury Publishing PLC. Edición de Gordon Minter.

- Tristana. 2017. Londres: Bloomsbury Publishing. Edición de Gordon Minter.

- Tristana. 2019. Londres: Bristol Classical Press. Edición, introducción, notas y bibliografía de Gordon Minter.

EE. UU.:

- Doña Perfecta. 1903. Nueva York- Cincinnati: American Book Company. Introducción, notas y vocabulario de Edwuin Seelye Lewis.

- Marianela. 1903, 1910. Boston: D.C. Heath \& Co. Introducción, notas y vocabulario de J Geddes, Jr; Freeman M. Josselyn, Jr.

- Marianela. 1903. Nueva York: W. R. Jenkins.

- Doña Perfecta. 1919/1925. Boston: Ginn \& Company. Introducción y notas de A. R. Marsh.

- Gloria. 1927. Nueva York \& Londres: The century Co. Edición, notas, ejercicios y vocabulario de Alexander H. Krappe; Lawrence M. Levin.

- Torquemada en la hoguera. 1932. Nueva York: Instituto de las Espańas, Estados Unidos. Introducción y notas de Ángel del Río.

- Doña Perfecta. 1940. Knoxville: University of Tennessee: D. C. Heath and Company Boston. Adaptada a primeras lecturas, notas, ejercicios y vocabulario de William F. Byess.

- Doña Perfecta. 1950. Boston: Ginn and Co. Introducción, notas y vocabulario de Paul Patrick Rogers.

- Marianela. 1951. Boston, Massachusetts. Ginn and Company. Edición, notas, vocabulario y ejercicios de Nicholson B. Adam. 
- Misericordia. 1958. New York: Columbia University. Edited for College Students. Introducción, notas, vocabulario y ejercicios de Ángel del Río.

- La sombra. 1964. New York: University of Pittsburg. W. W. Norton \& Company Inc. Estudio y texto en español. Edición de Rodolfo Cardona.

- Doña Perfecta. 1965. Nueva York: Dell Publishing Co. The Laurel Language Library. Introducción y notas de Rodolfo Cardona.

- La de Bringas. 1967. New Jersey: University of Texas. Prentice-Hall. Introducción y notas de Ricardo Gullón.

- Dona Perfecta. 2014. [Doña Perfecta]. United States: Independent Publishing Platform.

- Dona Perfecta. 2016. [Doña Perfecta]. United States: Edición de Createspace Independent Publishing Platform.

- Dona Perfecta. 2018. [Doña Perfecta]. United States: Edición de Createspace Independent Publishing Platform.

- Zaragoza. 1926. Boston, Nueva York: Ginn and Company. Introducción, notas y vocabulario de John Van Horne.

- Juan Martín el Empecinado. 1929. Stanford: Stanford University Press. Introducción, notas y vocabulario de Paul Patrick Rogers.

- Trafalgar. 1941. Nueva York: Oxford University Press. Adaptación de Ramón Espinosa and Alden R. Hefler.

- La batalla de los Arapiles. 1941. New York: Odyssey Press. Edición de J. B. Rael.

- Electra. 1902. Nueva York: American Brook Company. Edición con notas y vocabulario de Otis Gridley Bunnell.

- Electra. 1929. Madison Continental Plays. Edición de S.M. Tucker.

- El abuelo. Drama en cinco actos. 1929. New York: D. Appleton-Century Company. Introducción, notas y vocabulario de PH. D. H. Chonon Berkowitz.

- La de San Quintín. 1935. Nueva York: Appleton-Century-Crofts. En Nineteenth Century Spanish Plays. Ensayo sobre el teatro de Galdós. Edición de Lewis E. Brett.

- Mariucha. Comedia en cinco actos. [s. d.]. New York: D. C. Heath \& Co, Publishers. Introducción, notas y vocabulario de Ph. D. S. Griswold Morley.

- Lo prohibido. 2012. Miami: Editorial Rarebooksclub.com.

- Torquemada en la hoguera. 2012. [Torquemada en la hoguera. La mula y el buey. La pluma en el viento. La conjuración de las palabras]. Miami: Editorial Rarebooksclub.com.

- Los cien mil hijos de San Luis. 2012. Miami: Editorial Rarebooksclub.com

- Fortunata y Jacinta. Dos historias de casadas. 2013. Miami: Editorial Rarebooksclub.com.

- Torquemada en la Cruz. 2013. Miami: Editorial Rarebooksclub.com.

- Torquemada y San Pedro. 2013. Miami: Editorial Rarebooksclub.com.

- Montes de Oca. 2013. Miami: Editorial Rarebooksclub.com. 
- Los Ayacuchos. 2013. Miami: Editorial Rarebooksclub.com.

- La revolución de Julio. 2013. Miami: Editorial Rarebooksclub.com.

- La vuelta al mundo en La Numancia. 2013. Miami: Editorial Rarebooksclub. com.

- Los Condenados. Drama en tres actos. 2013. Miami: Editorial Rarebooksclub.com.

- Casandra. Novela en cinco jornadas. 2013. Miami: Editorial Rarebooksclub. com.

- Mariucha. Comedia en cinco actos. 2014. Miami: Editorial Rarebooksclub. com.

\section{Rumanía:}

- Fortunata y Jacinta. 1970. Bucarest: Edit D.P. Destinada a Institutos de Enseńanzas Medias. Selección del profesor C. Dubanianu.

\section{Rusia:}

- Capazoccbl. 1953. [Zaragoza]. Lengua: español. Ilustraciones de Goya y pintores de la época. Con notas de Agustín Alcaide Ibieca.

\section{Traductores y lectores de Pérez Galdós}

Decía Sartre, en ¿Qué es la literatura? (1967: 67): «El objeto literario es un trompo extraño que solo existe en movimiento. Para que surja, hace falta un acto concreto que se denomine la lectura y, por otro lado, solo dura lo que la lectura dure. Fuera de esto, no hay más que trazos negros sobre el papel». Esta reflexión nos lleva a volver sobre la consideración social de la literatura y su aceptación pública, en la época que salen de imprenta las obras de Pérez Galdós. A finales del siglo XIX hay elementos que favorecen la aparición de nuevos lectores tales como el auge de la actividad editorial, la importancia de la prensa y el no menos influyente papel del traductor. Pérez Galdós, escritor a la vez que coeditor, primero, y editor independiente, después, era dueño de un periódico, La Guirnalda, desde el que anunciaba sus novelas, insertaba fragmentos de los Episodios nacionales y atendía a otras casas extranjeras como la Hachette de París.

La moda francesa del folletín de la prensa sigue siendo un éxito. Galdós, a pesar de no gustarle que el arte llegase al lector en pequeñas dosis, y quejarse del oficio de escritor, utiliza esta forma de difusión en la que advierte algunas ventajas, particularmente económicas. Sus novelas y Episodios nacionales aparecerán en los folletines de la prensa española, francesa, italiana, polaca y rusa. Traductores franceses, como Maurice Bixio, (López 1993: 128) adelantaban la obra por capítulos en el feuilleton, y luego la editaban en volumen, una forma de dar publicidad y de comprobar su posible éxito.

En cuanto a la figura del traductor, los hay que visitan Espańa, se interesan por la lengua española, aprenden con facilidad y se dedican a traducir a novelistas españoles, entre ellos a Galdós; así, el resultado es muy variado y en ocasiones mediocre y malo. A otros traductores, que no conocen bien nuestra lengua, les resultaba difícil adaptar a la suya aquella forma de hablar de la gente popular de los barrios madrileños, que con tanta gracia y arte ponía don Benito en boca de sus personajes. Ante esto el traductor desprecia tal singularidad, o bien la adapta a su lengua con el consiguiente resultado, en una clara domesticación de la traducción. Algunos arriesgan su versión siguiendo 
directrices políticas como forma de complacer al dueño del periódico, ganar nuevos lectores y obtener beneficios económicos. No es de extrańar que, en alguna ocasión, el traductor solicitara al escritor autorización para alargar determinados capítulos, e incluso cambiarle el título, con el fin de agradar y vender más libros. A medida que avanza el siglo XX se advierte una mayor profesionalización en este oficio.

Por orden cronológico de la primera obra publicada, y siempre según nuestras investigaciones, seguiremos al escritor por los distintos países. La primera obra editada fuera de España es La Fontana de Oro, en Alemania, 1872, si bien en la reconocida Colección de Autores Españoles creada en 1860 por el hijo del iniciador de esta editorial. Friedrich Arnold Brockaus, su fundador, comenzó con una tienda en Ámsterdam, en 1805, dedicada a la venta de periódicos y libros de política, literatura e historia, que más tarde amplió a negocio editorial. Su prestigio le permitió mantenerse hasta el año 2009. Pérez Galdós continuó en los talleres y planchas alemanas durante el siglo XX. Sus novelas más traducidas han sido Doña Perfecta, Marianela, Miau y El amigo Manso. Por lo que respecta a los Episodios nacionales fue editada la primera serie, a excepción de La Corte de Carlos IV, y La campaña del Maestrazgo bajo el título de Der Roman einer Nonne [Historia de una monja]. Esta curiosa y temprana edición interesó a su editor, Sachs \& Pollák, por el protagonismo e historia amorosa de Marcela. En cuanto a Electra, que supuso un gran ruido en Espańa y un gran éxito, agradó de inmediato en Alemania, porque en ella trata el escritor de mostrar nuevos aires, en los que la mujer luchaba por su emancipación. Fueron las novelas de tesis y aquellas en las que se ponía de manifiesto la sociedad española y el interés por la mujer, en general adelantada para aquellos ańos, junto a la educación, el tema religioso y la intolerancia, las que más gustaron a los alemanes. A partir del año 2000, con el auge del español, se vuelve a leer a don Benito y encontramos nuevas traducciones de Marianela, Tristana y Nazarín.

En Italia se traducen novelas, episodios, teatro y cuentos. La primera edición conocida la hallamos en Milán, La Fontana de Oro, de Federico Pozzani, 1874, traductor versado en la lengua española, según Paz de Castro (2019: 819). Siguen a La Fontana de Oro, Marianela, La familia de León Roch, Doña Perfecta, Gloria y Nazarín, entre otras. Galdós, y en general la novela española hasta este momento de 1874, no era conocido. Pero tan pronto salen a la calle las traducciones, la crítica pone de manifiesto la consideración de Pérez Galdós como el gran novelista moderno. Les interesó el escritor por su forma de acometer el tema religioso, la mujer, por el humor y la ironía que imprimía a sus novelas. Reconocen en don Benito al creador de unos personajes, con sus fortalezas y debilidades, muy humanos. No faltó la crítica adversa, principalmente por el uso popular que hace de la lengua española. Tras el estreno de Electra en Madrid la prensa italiana se hace eco, sin embargo, no acaban de ver a Galdós con las mismas cualidades de su novela para el género teatral. A pesar de las críticas, a finales de abril del mismo año 1901, se estrena Electra (ibid:: 823). La novela más traducida ha sido Tristana seguida de Misericordia, La Fontana de Oro y Doña Perfecta. Los Episodios nacionales no tuvieron la misma atención por parte de los traductores italianos que las novelas. Pérez Galdós, que había viajado a Italia con cuarentaicinco años, escribe su visión sobre aquel hermoso país, en forma epistolar y en ocho apartados dedicados a las ocho ciudades visitadas (Navarro González 1990: 139). Reconoce en Italia las ventajas de la unidad nacional, y D. Benito, con esa capacidad artística que posee, ofrece hermosas descripciones de pai- 
sajes y monumentos. De ahí que los italianos tradujeran su Viaje a Italia bajo el título de Le città italiane.

En cuanto a la lengua inglesa, afirmamos hoy, como lo hiciera Bly en el Congreso Galdosiano de 2005 (Bly 2009), que los norteamericanos han sido «más activos» en las traducciones que lo ingleses del Reino Unido. En este país, la primera traducción corresponde a Gloria, y la última a Tristana, en 2016; además de episodios, encontramos una obra de teatro, Miau, y un cuento. En EE. UU. la primera obra publicada es también Gloria, y la última novela León Roch: a Romance, en 2018; se han editado episodios y teatro, entre ellos dos adaptaciones de Electra y, recientemente, en 2017, The Grandfather. En el Reino Unido Doña Perfecta, seguida de Tristana y Fortunata y Jacinta han sido las más traducidas; mientras que en EE.UU. han preferido Doña Perfecta y Marianela.

La edición y venta de libros de Pérez Galdós, y principalmente de sus novelas, pero también de los episodios, sigue en auge en Estados Unidos, si bien los procedimientos de la edición han cambiado. Rarebooksclub Com, Amazon y sus filiales en Miami y Memphis, Createspace Independent Publishing Plataform y Books LLC, marcan la vigencia de Pérez Galdós con datos de impresiones recientes tanto en inglés como en español. El Reino Unido cultivó especialmente la amistad con España, que estaba de moda desde el Romanticismo. Se sucedieron los viajes, los estudios hispánicos y, en 1927, se crea la primera cátedra de español en Oxford, que ocuparía, desde enero del año siguiente, Salvador de Madariaga (Garbisu 2017:1); no obstante, sabemos que desde 1903 se enseña español tanto en Oxford como en Cambridge. La influencia de la novela social inglesa tiene gran resonancia en el continente europeo y Dickens, Thackeray y George Eliot son los escritores más reconocidos, y pronto los británicos se deleitan con aquellas obras de Pérez Galdós que reflejan la España de la época. Traducen primero Gloria y luego Doña Perfecta porque en ambas se pone de manifiesto la lucha de las dos Espańas. Recordemos que la Asociación de Hispanistas se funda en Oxford, en 1962 y, casi de inmediato crece enormemente y los estudios del espańol se extienden por todo el mundo. En EE. UU., y en la Asociación, requieren mención especial los galdosistas, con rigurosos estudios publicados en las distintas revistas especializadas, un número creciente de traducciones y de tesis doctorales en las universidades, dedicadas exclusivamente a Pérez Galdós. Todo ello se ve reflejado en el número de versiones. Admiran en don Benito su capacidad para crear personajes tan humanos y naturales que calan hondo en el lector, para presentar los problemas sociales y morales, reconocen su humor, su lengua, su proceso creativo, se fijan en el problema religioso, pero se sienten atraídos por la forma de narrar lo que sucede en la sociedad madrileńa; reparan en la importancia de la mujer, la vida en el Ateneo, esas veladas de la clase acomodada que luego imita la burguesía, en donde se juntan el cesante con el empleado y el comerciante, haciendo todos ostentación de lo que carecen, y resultando, en muchas ocasiones, hasta cursis.

La primera traducción conocida al ruso es El audaz y la última, La Corte de Carlos $I V$, en un mismo volumen con La Fontana de Oro, en 2018. No obstante, además de las reseñadas tenemos noticias de otras obras de Galdós, La sombra, Marianela, Lo prohibido, Misericordia e incluso cuentos, de las que no hemos encontrado datos, pero que refieren los galdosianos Valentina Guinko (1993: 67) y Chamberlin (1977: 144), entre otros. El interés por Galdós y su conocimiento fueron inmediatos. Entre la nómina de 
los escritores que se leían a finales del XIX figuraba Pérez Galdós junto a los novelistas franceses y rusos; las relaciones entre ellos y sus mutuas influencias eran objeto de artículos en la prensa de entonces. La crítica rusa reconoce que Galdós describe la sociedad española artísticamente, y que el centro de muchas de sus novelas son las costumbres y los problemas sociales, por lo que se le juzga de muy moderno. Algunos traductores dominaban el español, como es el caso de Pavlovski, también conocido bajo la firma de Yakovlev, que había estado en España, leído la literatura española y visitado la casa del novelista. Sin embargo, a otros les resultaba más sencillo hacer las traducciones al ruso desde el francés (Guinko 1993: 71). Las tres novelas con más ediciones son Doña Perfecta, La Fontana de Oro y El caballero encantado; de los Episodios nacionales, La Corte de Carlos IV y Zaragoza. Los rusos conocieron, sin duda, el éxito de Electra pero no hemos encontrado datos de su traducción. Doña Perfecta gustó sobremanera a los rusos por su anticlericalismo y porque al final Pepe Rey, el héroe progresista y liberal, es asesinado por las fuerzas que representaban la intolerancia e intransigencia. La editorial del Gobierno ruso, Goslitizdat, que seleccionaba sus obras con marcadas intenciones políticas, llevó a imprenta La Fontana de Oro, entre otras. Al inicio de la guerra civil española, los rusos deciden traducir los Episodios nacionales. Eligen Cádiz, Zaragoza y Juan Martín el Empecinado que reflejaban la lucha contra Napoleón, la resistencia y el valor de los españoles contra el invasor. La citada editorial, a través de la prensa y de los prólogos de sus traducciones, se ocupaba de presentar a Pérez Galdós ante los posibles lectores como un escritor de izquierdas que pensaba de España lo mismo que Marx (Chamberlin 1977: 148). Sin embargo, reconocieron siempre su calidad artística, su capacidad para crear personajes con los que se identificaban, así como el arte para imaginar un ambiente tan cercano y familiar en las novelas, que pareciera que el lector formaba parte de ellas, por lo que sentían y sufrían con el desarrollo de su trama.

El lector danés tuvo ocasión de leer pronto la obra de don Benito, quien conocería Dinamarca en compañía de Alcalá Galiano en 1887. Las primeras novelas traducidas son La familia de León Roch, 1881, Doña Perfecta y Torquemada.

En fechas próximas, los húngaros leyeron en su lengua Gloria, Misericordia y Doña Perfecta. Nuevamente encontramos similar atractivo por el tema religioso y por saber de España a través de un escritor cervantino como Galdós. Quizá, como apunta Arnáiz (1977: 41), habría que buscar el interés «no solo en factores literarios, sino también extraliterarios, profundamente ligados con los acontecimientos históricos de la guerra civil española».

Fue en Leiden, sede de la Universidad más antigua de los Países Bajos, donde se hizo la primera edición neerlandesa conocida, Doña Perfecta, 1883, a la que siguieron Marianela y La familia de León Roch. De la imprenta neerlandesa salió La campaña del Maestrazgo, titulada Zuster Marcela. Roman eener Non, en 1903. A pesar de las dificultades y la distancia Electra se edita en 1901. Hubo que esperar, después, casi cien ańos para volver a encontrarnos, en la década del apogeo del galdosismo, con nuevas traducciones de novelas. No era fácil traducir del español, pero supieron fijar su atención en un novelista de éxito y España estaba de moda gracias a Galdós.

La traducciones al francés se inician, según los datos obtenidos durante la presente investigación, con Doña Perfecta y Marianela, seguidas de El amigo Manso y Misericordia. De los episodios conocemos las curiosas vicisitudes de la traducción de La campaña del 
Maestrazgo, Soeur Marcela (Bush 1979); con este título, su problemático traductor daba a entender cuáles eran sus intereses. La Grange de Granges, un político retirado, enamorado de España, solicita a Galdós le permita «hacer una narración romántica a esta evasión y no contarla en dos renglones secos», escribe Bush, (ibid.: 122) quien pone de relieve los entresijos de esta versión francesa en la que veremos cómo don Benito ha de someterse a la conveniencia del traductor y del editor del periódico. Francia, centro cultural del mundo, recibió a Pérez Galdós calurosamente. Galdós es un innovador que moderniza la lengua de Cervantes con sus giros populares, decía uno de sus críticos, el hispanista Savine, y prologuista de la edición de Doña Perfecta de 1885 (Díaz 2017: 131-166). Aprecian en Marianela las influencias de Comte y Taine, las mismas en las que se fundamentaba Zola; en El amigo Manso la filosofía krausista, con la que simpatizaba Galdós sin serlo; en Misericordia la vuelta al mundo espiritual en el que reinan el amor y la piedad; en Doña Perfecta veían reflejada la España religiosa e intransigente; en Fortunata y Jacinta los entresijos naturales del Madrid de aquel entonces con sus comercios, oficios, modos de vivir en aquellas viviendas donde todo se sabía y aquel salir y entrar de los señoritos de cafés y tertulias; o el tema de la mujer, que tan bien tratara don Benito, en Tristana. Sobre Electra no tenemos datos de ediciones, pero sabemos que tras muchas vicisitudes se adaptó al francés y subió al escenario de la Port Saint Martín, en mayo de 1904, donde alcanzó las 185 representaciones, para luego comenzar la gira por otras ciudades (López 1990a: 414).

Pérez Galdós fue traducido bien pronto al polaco. Tenemos algunos datos de dos ediciones de finales del siglo XIX, Doña Perfecta y Marianela. En el siglo XX, en la revista jesuita de carácter sociocultural Przeglad Powszechny, aparecieron insertadas Gloria, La desheredada, Nazarín, y Torquemada y San Pedro (Narebska 2011:71); desconocemos su traductor y las fechas, aunque sabemos que fue con anterioridad al cierre de la revista en 1953. Años más tarde, a partir de mediados de siglo, encontraremos de nuevo Doña Perfecta y otras novelas, La Fontana de Oro, La sombra, Misericordia y Tristana. En cuanto a episodios publicaron Saragossa y Bitwa pod Arapilami. Zofia Szleyen es la traductora que estudia y hace las versiones de dos de las novelas y de los Episodios nacionales, una escritora polaca, activista política, intelectual, periodista y química, interesada en la literatura. Con motivo de la guerra civil española, Szleyen se traslada a Barcelona donde permanece dos ańos. Aprende el espańol y comienza a trasladar a su lengua a escritores españoles. Sus traducciones y el estudio, que acompaña como introducción a los Episodios nacionales, son de marcado tinte político y propagandístico. Los cambios políticos en Polonia consiguen también que las siguientes traducciones tengan carácter bien distinto. Polonia interesada en Galdós recibió con éxito de público, en 1975, la puesta en escena de Misericordia, a cargo de la compañía de teatro María Guerrero de Madrid, e igualmente dio buena acogida, a través de sus pantallas, a la serie Fortunata y Jacinta de Televisión Española. La última edición que conocemos es Casandra, de 2013.

En vida de Pérez Galdós se tradujo al rumano, con varias ediciones, Marianela, la primera conocida es de 1890 y, mucho más adelante, Doña Perfecta. El profesor Munteanu (1995) da cuenta de una edición de Gloria, anterior a 1970, sin que hayamos obtenido nuevos datos. Desde el siglo XVIII los rumanos conocían la literatura española y será a mediados de la siguiente centuria cuando algunos estudiosos comienzan a viajar 
y a comprender mejor España. Tras las contiendas bélicas, el inicio de la transición y la recuperación de Rumanía, Bucarest se convertirá en un foco de hispanistas, se incrementarán las traducciones y los estudios críticos de escritores entre los que destacará Pérez Galdós.

En Suecia, publican Doña Perfecta y Marianela en 1893 y 1894, y Fortunata y Jacinta, en 1992. Doña Perfecta fue traducida por Karl August Hagberg, periodista, miembro de la Academia Sueca y conocedor de varias lenguas modernas. Como académico conoció las candidaturas españolas al Premio Nobel, tanto de Ángel Guimerá como de Pérez Galdós, y sobre este confeccionó un largo informe. Buen conocedor de la obra galdosiana selecciona para su traducción la novela que en el extranjero venía a resumir la España que deseaban conocer. Su hermana, Augusta Hagberg, tuvo menos éxito con Marianela. La versión de Fortunata y Jacinta, a cargo del diplomático y experto en lenguas modernas Peter Landelius despertó interés. En el catálogo de la Biblioteca Pública de Estocolmo, junto a otras ediciones en español del escritor, son las tres únicas novelas conocidas en sueco.

A pesar de la situación política por la que atravesaban el centro y este de Europa, el interés de los checos por leer a Galdós no fue un obstáculo para que pronto se le tradujera, y el escritor autorizó las primeras ediciones de su obra en esta lengua. Nazarín, 1897, fue impresa en Praga y traducida por Antonín Pickhart, el primer hispanista conocido. Años después se editan Electra, 1901, y Marianela. Los checos continuaron publicando a Galdós en los años veinte, treinta y, particularmente, en los cincuenta Doña Perfecta y los episodios de Juan Martín el Empecinado y Zaragoza.

Pocas y tardías fueron las obras vertidas al portugués, Las novelas de Torquemada, Tristana y La de Bringas, a excepción de Electra que fue impresa el mismo año de su estreno en España por el traductor, Ramalho Ortigao, crítico literario y folletinista del periódico Jornal do Porto.

Marianela es la única novela de Galdós que ha sido traducida y editada en finés, en 1921, un año después de haber fallecido su autor. Su adaptador es J. Lehtonen un periodista y crítico que cursó literatura en la Universidad de Helsinki.

De las lenguas habladas en España hay algunas pocas traducciones en gallego y en catalán; en la primera tan solo una obra, simplemente, porque leían en español. En Cataluña Pérez Galdós era muy querido y considerado un maestro. Son conocidas su relaciones con el escritor Narcís Oller, con el crítico Yxart y, en general, con la prensa catalana. Recordemos que el escritor vendía en exclusiva su obra, en esta región, a su estimado editor Antonio López. Galdós, en 1867, a la vuelta de su viaje a París, se detuvo en Gerona, visita que le inspiró para escribir el episodio de Gerona (Cardona 1980: 154). Pronto aparecerán las traducciones en forma de versiones teatrales: Marianela, El abuelo y Gerona. La prensa y la crítica conocían bien su obra y parece que alguna de sus piezas teatrales, El abuelo, tuvo más aceptación en Cataluña que en Madrid. A pesar de las pocas traducciones, sabemos por la prensa que el escritor era muy apreciado y así lo reconoce la profesora Cardona (ibid:: 161): «La inclusión de don Benito en la cartelera del Teatre Intim supone que Barcelona, el París cultural de fin de siglo, consideraba de gran calidad y manifiesto vanguardismo la obra de Galdós, porque el grupo y su director solo seleccionaban obras que tuvieran esta estima». 
Reciente ha sido el interés de los búlgaros por la obra galdosiana. La confrontación política en el centro de Europa, la Segunda Guerra Mundial y los bloques que se conformaron impidieron dedicación alguna a la literatura de otros países. La primera obra editada, que sepamos, es Zaragoza, en 1945. Más adelante, en 1970, uno de los traductores de Pérez Galdós, Teodoro L. Neikov, (Arnáiz 1977:40) conmemora los cincuenta años de su muerte con un interesante estudio titulado Benito Pérez Galdós y su obra. Se publican entonces otros episodios y años después, Doña Perfecta, Fortunata y Jacinta, y Tristana. Episodios y novelas que permitían conocer la historia de Espańa, la sociedad española y el Madrid del XIX.

A pesar de las contiendas bélicas, en 1952, hallamos la primera edición en serbio de Pérez Galdós, Doña Perfecta, a cargo del poeta Gustav Krklec. Luego, habrá que esperar al mismo año de la independencia de Serbia, 2006, para encontrar otras traducciones. Instituciones como el Aula Cervantes y la Asociación de Hispanistas han impulsado el español en el país. Eslovaquia con su lengua oficial el eslovaco, de gran similitud con el checo, ha publicado de Pérez Galdós sus novelas más reconocidas, Doña Perfecta, y Fortunata y Jacinta, y un episodio, el de Zaragoza.

Hacia los años 50, según el profesor y traductor chino Dong Yansheng (Carrazón 2007), la obra literaria española en las universidades chinas era escasa pero entre ellas figuraban las novelas de Benito Pérez Galdós que pronto leyeron los estudiantes de español. Años después y con el auge que alcanzó esta lengua, los mismos jóvenes de entonces se convirtieron en los primeros traductores a los que se sumaron nuevas generaciones. El único cuento editado, La conjuración de las palabras, se ha traducido al chino por el propio Yansheng (2005:181-186). Casi doce años después de que se fundara la República Popular de China, en 1961, la Casa Editorial de la Literatura Popular China publica, según nuestros datos (Zhao 2009), la primera novela de Pérez Galdós, Doña Perfecta. A partir de 1978, con libertad para la impresión de obras extranjeras, encontramos Marianela, Gloria y Fortunata y Jacinta. La casa Editorial de Versión de Shanghái redacta un gran proyecto, Obras escogidas de Pérez Galdós, con el propósito de traducir y publicar veinte de su obras, que comenzaron a editar a partir de 1993, y así aparecen Halma, La Fontana de Oro, El amigo Manso, Tristana, Tormento, Gloria, Ángel Guerra, además de Doña Perfecta. El creciente interés que despierta lo español, en la actualidad, redundará en nuevos estudios y traducciones de Pérez Galdós. ${ }^{1}$

En Estonia se publica La desheredada. Lo que demuestra esfuerzo y atractivo por un escritor español que contaba con traducciones en los países limítrofes, a sabiendas de que una gran parte de los estonios son rusoparlantes.

Las primeras obras editadas por los griegos fueron Tristana, El caballero encantado y La sombra, y la última conocida, Miau, en 2018. Esto corrobora que el interés por el novelista está vivo y que podrían seguir en aumento sus lectores.

Los japoneses también se interesan por el novelista español traducido en toda Europa, y editan Marianela en 1993, Fortunata y Jacinta en 1998 y Doña Perfecta en 2015. Esta última ha sido adaptada al japonés por Eizo Ogusu, profesor de la Universidad de Meiji.

1 Es posible encontrar traducciones de Pérez Galdós en la siguiente página web escrita en caracteres chinos: https://book.douban.com/author/140095/books?start=0\&format=pic\&sortby=collect. 
Tan solo conocemos una versión en noruego, Fortunata y Jacinta, 1998, novela y documento fidedigno de la Espańa del último cuarto del siglo XIX, en la que se refleja todo el cambio experimentado por la burguesía comercial y la vida diaria del Madrid decimonónico.

Los persas leen a Pérez Galdós a partir del año 2001; publican dos de sus novelas más reconocidas, Nazarín y Doña Perfecta; de esta última conocemos tres ediciones, la más reciente del año 2015.

Las traducciones de Pérez Galdós a la lengua árabe datan del año 2005. Tánger y El Cairo son los dos focos editoriales africanos junto a la sobresaliente labor, en Madrid, de Isidora Ediciones. Es notorio el interés de estudiosos y traductores por las obras cuyos asuntos están relacionados con África, Aita Tettauen, así como por las novelas de más éxito, Marianela, Fortunata y Jacinta, Tristana y Doña Perfecta. Les gusta el Galdós que muestra las dualidades fanatismo y tolerancia y ciencia y religión, pero también el que narra y describe la vida cotidiana; en palabras de Galdós ese «maravilloso drama de la vida» (cita en García Bolta 2001: 10). Junto a la novela, traducen el teatro y el cuento, género que goza de gran predicamento. Galdós sigue creciendo en lectores. Según la entrevista realizada en Tánger (abril 2018), en el Instituto Español Severo Ochoa, el profesor y galardonado traductor Omar Bouhachi, anuncia una nueva edición de Miau, en árabe.

Dos novelas Gloria y Doña Perfecta han sido traducidas al hebreo. Dos mujeres bien distintas son las protagonistas de la intolerancia religiosa; dos mujeres que encarnan dos ideales diferentes. El interés de Galdós por el tema judío no pasa inadvertido y, 135 años después, en 2012, se traduce Gloria a la lengua hebrea.

En una de las lenguas oficiales de India, el malabar (original malayalam), hemos encontrado publicada la obra de teatro Los Condenados. Igualmente, en la lengua africana suajili, la traducción del episodio Los Ayacuchos. Ambas obras han sido editadas en 2013 por Rarebooksclub Com, con sede en Miami.

Pérez Galdós observa todo lo que tiene a su alrededor y traslada a su novela, con maestría y arte, la realidad de Espańa, la compleja problemática de la sociedad, desde el analfabetismo a la educación e instrucción de la mujer, el feminismo, los problemas de la intransigencia religiosa, la vida en los salones y sus tertulias, el «quiero y no puedo» de la nueva clase social, la asistencia a los teatros, la vida en los comercios, en las casas de vecindad. Hace de la sociedad española un análisis exhaustivo y se rebela ante el anacrónico sistema social, desde su perspectiva de hombre liberal o reaccionario burgués, siempre moderado. Todas estas son cuestiones que interesaron a los traductores y que hicieron llegar a su público. Galdós quiere también enseñar la historia de España y escribe los Episodios nacionales en donde los lectores se sienten atraídos por aquellos personajes «secundarios» que les harán sentir y gozar. Una vez que Galdós tiene asegurado lectores, con novelas como Doña Perfecta, Gloria y Marianela, se aventura a que estos le sigan en las llamadas contemporáneas y escribe novelas que hoy continúan en las imprentas como Tristana y Misericordia, entre otras.

Pérez Galdós es moderno, está de actualidad porque narra de forma magistral nuestros defectos, la intransigencia, la intolerancia, defiende el papel de la mujer, a la vez que se interesa en que conozcamos y aprendamos de la historia de Espańa, y fundamenta todos los males en la falta de instrucción, en la educación. Con todos estos ingredientes 
teje unas maravillosas historias en las que sus personajes son tan humanos que soñamos y sentimos con ellos. Han pasado casi 150 años desde que se publicara La Fontana de Oro y la vitalidad de la obra de don Benito Pérez Galdós es auténtica, no solo por las traducciones y ediciones en papel sino por su presencia en otros lenguajes y formas, cine, música, cómics, etc., que harán necesaria la continuidad de este estudio. Schücking (1969: 12) lo explicaba así en El gusto literario: «No son las obras de arte y las formas las que deciden por sí mismas: quienes deciden sobre ellas son los hombres».

\section{CONCLUSIONES}

El éxito de Pérez Galdós y su consideración hasta nuestros días es de tal vitalidad que justifican este estudio. Las numerosas traducciones y la notable recepción de su obra en otras lenguas han demostrado que el novelista ha interesado siempre y sigue interesando.

Los apartados anteriores de este trabajo han reflejado el decisivo papel que ejercieron editores y traductores en la recepción de las obras de Galdós. Sabemos que estos sometían a cambios el texto objeto de su trabajo, incluso hasta el título de la obra, debido a su mayor o menor grado de conocimiento del español, su interés político, folletinesco o simplemente comercial, además del eminentemente literario, en muchas de las versiones. El autor se veía en la obligación de aceptar las propuestas con mayor o menor resignación, si bien establecía algunas condiciones a la hora de autorizar la traducción y edición. Galdós conocía bien este sector puesto que vivía de la venta de sus libros y de su trabajo como editor. Volvemos pues sobre una profesión, la del traductor, no siempre visible y muchas veces silenciada en las fuentes y estudios. Sin embargo, el éxito de las traducciones y por lo tanto de la recepción de la obra galdosiana dependía de estas versiones. Consideramos por lo tanto fundamental su trabajo condicionado, en no pocas ocasiones, por el gusto de los lectores y por la venta de su obra. El estudio de las traducciones y ediciones del escritor, junto a las circunstancias políticas y sociales, constituyen una fuente de información para el conocimiento de la recepción de la obra de Pérez Galdós fuera de España.

En la labor de traductores y editores del escritor queremos destacar los siguientes datos. En lengua inglesa, EE. UU. ha traducido treintaiséis obras del autor en sesentaitrés ediciones, y el Reino Unido diecisiete obras en treintaicuatro ediciones. Francia ha llevado a la imprenta treintaiséis títulos en sesentaitrés ediciones. En italiano se han leído veintinueve obras en cincuentaicinco ediciones. Alemania cuenta con cuarentaiocho ediciones de veintitrés obras, y Rusia traduce treintaitrés obras en cuarentaitrés ediciones. En el centro de Europa destacamos el polaco con quince ediciones de quince obras; el rumano con catorce ediciones y once obras; el búlgaro, con doce ediciones, el checo con trece ediciones, y el neerlandés con catorce. Fuera de Europa subrayamos las veinticuatro ediciones de trece obras en árabe, y las veintidós en chino de catorce obras. En los años que median entre 1872 y 2019 las novelas más traducidas y por lo tanto las más leídas han sido Doña Perfecta, sesentaisiete ediciones; Marianela con cuarentaiséis; Tristana con treintaitrés y Misericordia con veintinueve. Anotamos a continuación otros datos relevantes. De Doña Perfecta, salieron en inglés, de las imprentas EE. UU., doce ediciones, le siguen Alemania con ocho, Rusia con siete, Francia e Italia con cinco. De 
Marianela hemos contabilizado ocho ediciones en EE. UU., seis en Alemania y en Francia, siete. De Tristana, ocho en italiano y cuatro en el Reino Unido. De Misericordia hemos reseñado siete ediciones en italiano y seis en francés. En estos veinte años del siglo XXI los traductores y editores de Pérez Galdós continúan ofreciendo a los lectores principalmente sus novelas. Al francés se traducen veintidos de las obras de don Benito, al italiano diecisiete, al árabe trece, al chino siete y al inglés, en EE. UU. dieciocho y en el Reino Unido, cinco. En cuanto al número de ediciones queremos destacar veinticuatro en árabe, veintitrés en francés, diecinueve en italiano; en lengua inglesa, siete en el Reino Unido y veinticuatro en EE. UU., cinco recogidas en alemán y ocho en chino. Vuelven a editarse las mismas novelas y repiten Doña Perfecta y Tristana. Los árabes, los iraníes y con posterioridad los hebreos son un vivo ejemplo del interés más reciente por el escritor canario y por España.

Es notorio igualmente que el éxito del estreno de Electra en Madrid, en 1901, resonara de inmediato fuera de España. Ese mismo año y a los pocos meses, sus personajes suben a los escenarios de Alemania, Chequia, Países Bajos, Italia, Portugal y más tarde de Francia y EE. UU., si bien en esta última se estrenó en español en 1902. Y todo ello con las correspondientes autorizaciones del autor que habían de recibir los adaptadores de esta obra y con los medios de comunicación de la época. Espańa estaba de moda gracias al escritor cuyas preocupaciones sociales supo trasladar a un público ávido de identificarse con sus personajes. Con Electra, Galdós logra provocar a una sociedad necesitada de un cambio. Traductores y adaptadores estuvieron prestos para dar a conocer al público el escándalo que se había suscitado en España con el feminismo galdosiano.

La relevante labor de determinadas instituciones y entidades han favorecido las traducciones de Pérez Galdós en los distintos países y lenguas, tales como las asociaciones de hispanistas, el Instituto Cervantes y la Biblioteca Virtual Cervantes, así como el Ministerio de Educación espańol con su apoyo a las traducciones, y la encomiable labor de Isidora Ediciones y de Isidora. Revista de Estudios Galdosianos. Hemos de elogiar, sin duda, el trabajo de los hispanistas y galdosistas de EE. UU. Su esfuerzo y empeño han contribuido a que España, el español y su literatura y, concretamente, a que el escritor Benito Pérez Galdós haya sido conocido, estudiado y leído. Finalmente, los buenos oficios de traductores y editores lo han hecho posible.

Con motivo del centenario galdosiano y del creciente interés en el mundo por España y lo español, se abren nuevos retos a los jóvenes traductores y editores literarios. Su capacidad creativa para traducir al escritor Pérez Galdós a otras lenguas se torna imprescindible para la captación de nuevos lectores.

Somos conscientes de que esta línea de investigación no está agotada, pero confiamos en que pueda servir para revisar y actualizar las bibliografías actuales. 


\section{CAPÍTULO VIII}

Consideraciones sobre la traducción al francés del cuento inédito Rompecabezas de Benito Pérez Galdós

Marie-Claire Durand Guiziou

Universidad de Las Palmas de Gran Canaria

\section{INTRODUCCIÓN DESDE LA VISIÓN TRADUCTOLÓGICA}

Con fecha tres de enero de 1897, se publica el cuento Rompecabezas de Benito Pérez Galdós en el periódico madrileño El Liberal, acompañado de una ilustración de gran formato que recrea una atmósfera festiva propia de un ambiente navideño. Tras un análisis previo del cuento y el correspondiente trabajo de documentación antes de proceder a la traducción, situamos el cuento en un mundo alegórico con vena fantástica y fenómenos sobrenaturales donde el narrador deja traslucir su humor, a veces socarrón.

En primer lugar, glosaremos brevemente el texto para aportar alguna luz sobre la historia de tres personajes - padre, madre y un recién nacido, acompanados de un borriquillo- que caminan penosamente, huyendo de persecuciones por el desierto de Egipto, en busca de un refugio seguro. El texto no nos devele nunca su identidad. El narrador toma como pretexto el desciframiento de un papiro del lejano Oriente que transmite el relato.

Podría decirse que Rompecabezas tiene una doble lectura. La primera nos descubre un cuento infantil y navideño que aporta su grado de fantasía y de magia. La segunda, más ponderada, desborda el contexto bíblico implícito (la Virgen María, san José, el niño Jesús y el burro), y nos invita a interpretar las dos partes del texto desde la reflexión, a partir de las metáforas «lindísimos monigotes» (Pérez Galdós 2004: 293) y "escritura muñequil» (Pérez Galdós 2004: 294) referidas a los jeroglíficos del papiro. Ya lo advierte el narrador inequívocamente: «Es la tal historia o sucedido de notoria insignificancia, si el lector no sabe pasar de las exterioridades del texto gráfico...» (Pérez Galdós 2004: 293).

La segunda parte del cuento nos introduce en otra dimensión, la de irrealidad al cambiar la suerte de los tres fugitivos. El elemento desencadenante se define en los términos alegóricos de «Eterno Señor» (Pérez Galdós 2004: 294) y se plasma en la figura humana de un riquísimo mercader que, al regresar de Tebas con su cáfila de camellos cargados de tesoros, se cruza con la familia de los pobres caminantes, y les brinda hospitalidad así como una generosa cantidad de monedas, entre ellas, una de oro para el niño. Libe- 
rada de sus penurias, la familia va a conocer la magnificencia de la urbe con sus festividades y sus ferias, su consumo y sus espejismos. Ahí el nene, ya llamado niño por su fulgurante crecimiento, acumula innumerables figurillas de personajes que le han comprado. Con el poder de su fuerza sobrenatural dará una vuelta de tuerca a toda la sociedad en miniatura que posee — alegoría de la sociedad moderna y sus desigualdadesal cambiar todas las cabezas de los personajes de baratijas que ha acopiado, rebajando así la condición de los más acomodados a un estatus degradado. Galdós, retomando su vena irónica, terminará el cuento con una sutil pero inequívoca alusión anticlerical, perceptible en el gesto del niño que deja caer en las manos de un chico de Occidente «algunos curitas cabezudos» $\mathrm{y}$ «no pocos guerreros sin cabezas» (Pérez Galdós 2004: 298).

Interesa subrayar que, si bien Galdós se abstiene de dar nombres a sus tres personajes principales, el privarlos de identidad (son fugitivos y mendigos anónimos) se ve compensado con unos retratos descriptivos y sicológicos donde prima una abundante adjetivación con variantes sinonímicas, siendo el niño el elemento alegórico descrito como «divino humanamente» sobre el que se focaliza toda la atención. Interesa, para la traducción, tener en cuenta que el narrador, al referirse al bebé que la joven madre lleva en brazos, declina unas variantes léxicas — nene, criatura, ángel de meses, hijito, pequeñuelo, hijo de la bella señora, precioso niño, precioso infante, chiquitín - cuyo paradigma sigue un orden que desvela la transformación sobrenatural del nene en niño en un tiempo irrisorio. Dichas voces vienen acompañadas de calificativos cuya función meliorativa refuerza la figura del protagonista sin nombre. En cuanto a la madre, el narrador realza reiteradamente su hermosura, su juventud, su pureza (comparándola con un lirio), así como su bondad e inocencia («bendita madre») (Pérez Galdós 2004: 296). Contrasta esa profusión adjetival que derrocha el autor al describir madre e hijo con la escueta caracterización del padre, al que se refiere aludiendo siempre a su gravedad y su ancianidad.

Como contrapunto a la falta de identidad de los caminantes fugitivos, comprobamos que el texto introduce, mediante una referencia intertextual, nombres propios con una motivación onomástica clara al tratarse de conquistadores que han quedado inscritos en la historia. Nombra así a Gengis Kan, Cambises, Napoleón y Aníbal. Son figurillas de bazar que el «hijo de la fugitiva» ha escogido en la feria gracias a la moneda de oro del mercader. Pero esos históricos patronímicos pierden su brillo, y los héroes, su prestigio al ser calificados de «arrogantísimos caudillos» (Pérez Galdós 2004: 297). Con la marca despreciativa que intensifica el superlativo, Galdós anticipa el final del cuento con la imagen del nińo que, decidido a transformar su mundo en miniatura desde nuevos valores, cambia la cabeza de cada uno de sus históricos personajes por la cabeza de un pastor.

La serie de nombres propios relacionados con la historia, sin llegar a plantear mayor dificultad para la traducción en este caso preciso, sí deben ser objeto de una comprobación en la cultura de llegada, dado que, además de sufrir un cambio fonético, llevan una grafía diferente ( $c f$. en francés, Gengis Khan, Cambyse, Napoléon, Annibal).

La verosimilitud del cuento se logra en la primera parte del cuento con la presencia de marcadores espaciales recogidos en los topónimos reales de una cartografía egipcia, como Djebel Ezzrit ${ }^{1}$ (lugar donde la familia se encuentra en el momento de su huida

1 Según la reseńa que ofrece Eustache Marie Pierre Marc Antoine Courtin, en l'Encyclopédie moderne ou Dictionnaire des hommes et des choses, vol. 9, éd. Th. Lejeune, Paris, 1830, el topónimo Djebel Ezzrit queda atestado (Véase: https://gallica.bnf.fr). 
en el desierto) y Tebas (ciudad de donde regresa el generoso mercader, sin nombre, que salva la situación de los perseguidos). En contrapunto, la referencia temporal que remite a un pasado lejano donde se cruzan dos elementos cronológicos diferentes, la Era Cristiana (subrayada con la mayúscula) y la cronología egipcia, correspondientes a civilizaciones opuestas, en la dicotomía Occidente frente a Oriente, complica voluntariamente la fecha que se diluye en la imprecisión. En efecto, el narrador señala irónicamente la fecha del papiro que se remonta a tres mil años y pico atrás, información que se modula con la subjetiva y burlona coletilla, «si se quiere» (Pérez Galdós 2004: 293).

Siguiendo con algunas dificultades en la labor traslatoria, señalaremos unos ejemplos que, sin que podamos hablar de verdaderos escollos, sí constituyen puntos de reflexión. Los encontramos en el íncipit donde comprobamos que los aspectos estructurales del cuento se plasman mediante numerosas secuencias digresivas donde no falta el deje irónico. Galdós introduce así comentarios sobre el proceso de la escritura, tales como dudas voluntarias, falsas correcciones, indecisiones en busca de la voz apropiada. El propósito de dichas digresiones tiene el efecto de secuenciar el texto en un tempo discontinuo que aligera el discurso y divierte al lector. Citamos: «Seamos eruditos», "Ayer, como quien dice, el ańo Tal de la Era Cristiana, correspondiente al Cual, o si se quiere, al tres mil y pico de la cronología egipcia» (...), «Pues señor... Digo que aquel día o aquella tarde, o pongamos noche...», «o por mejor decir», (Pérez Galdós 2004: 293), etc. Para la traducción, en esos casos concretos, es preferible no ser demasiado fiel a la formulación sintáctica del texto original a fin de evitar anacolutos que pueden derivar en incoherencias. Siendo la sintaxis menos maleable en francés que en lengua española, la frase deberá adoptar, no obstante, una fluidez rítmica acorde con el texto de partida sin perder de vista la intensidad de su contenido semántico, especialmente cuando se trata de las primeras líneas orientativas que ofrece el íncipit del cuento.

Nombraremos también alguna metáfora de difícil traducción como «lindísimos monigotes» en referencia a los jeroglíficos — palabra in absentia en el texto-, y a "papiro» que Galdós escribe papirus en cursiva, ¿acaso por su derivación del latín «papyrus», destacándose así la voz que sirve de pretexto para iniciar el cuento en su contexto oriental fijado en tiempos inmemoriales. Citaremos también los diferentes registros de lengua donde voces cultas (cáfila de camellos, caterva infantil) alternan con un habla más coloquial (áspides de mentirijillas). Interesa señalar también la creación verbal de «muñequil» repetida en dos ocasiones («escritura muñequil» (Pérez Galdós 2004: 294) e «industria muñequil») (Pérez Galdós 2004: 296), que la traducción ha intentado recrear a partir del campo léxico de muñeca o muñeco. Con la metáfora «muñequil», referida a la escritura, el autor evita voluntariamente escribir la palabra «jeroglífico» y recrea una atmósfera de juguetes en torno al protagonismo del niño. La traducción tuvo que conformarse con: «l'écriture figurative» en vez de «écriture hiéroglyphique» que alude a la voz jeroglífico, término que pareció oportuno descartar. Con ello, la traducción pierde en parte la imagen que recoge el adjetivo «muñequil». En el caso de «industria muñequil» tradujimos por «industrie des joujoux», donde el término joujoux alude claramente al mundo de los juguetes infantiles. En el primer párrafo del cuento donde el narrador se refiere a los signos del papiro con la metáfora «lindísimos monigotes» (Pérez Galdós 2004: 293), optamos por la expresión «superbes fantoches» dado que fantoche entra en 
el campo léxico de «poupée» $y$ «poupon» y puede recoger tanto la imagen de «muñequil» como la de «monigote» que el autor ha querido poner de relieve.

La alusión a antiguas monedas españolas del siglo XVII, «media pelucona o doblón de a ocho» (Pérez Galdós 2004: 295), (que no deja de introducir un tipo de anacronismo en el texto), ha exigido un trabajo de documentación. A nivel estilístico, citaremos el doble oxímoron «el dolor placentero y el gozo febril» que exigiría respetar esa figura literaria en el texto de llegada.

En definitiva, quizá debamos entender el título Rompecabezas desde esa visión del mundo que Galdós plasma desde la dualidad, los contrastes y las oposiciones. El cuento se convierte, como su título lo indica, en un "casse-tête», voz sinónima de "puzzle» en francés, por la que hemos optado en la traducción, aun a sabiendas de que el diccionario de la Academia francesa, la recogió en sus páginas solamente unos años después de la fecha en que Galdós escribió su cuento (ya se sabe que el uso de la palabra es siempre anterior a su entrada en el diccionario).

El traductor, convertido en aprendiz de Champolión, se ha prestado motu proprio al juego de reconstrucción de los elementos textuales y a la recreación del texto de partida, siguiendo la irónica advertencia del narrador que, en el íncipit, recomienda una lectura profunda del cuento que no se limite a «las exterioridades del texto gráfico» (Pérez Galdós 2004: 293) (alusión a la metáfora de los jeroglíficos del papiro) si se quiere «descubrir el meollo que contiene» (Pérez Galdós 2004: 293). ${ }^{2}$

\section{TRADUCCIÓN DEL CUENTO AL FRANCÉS ${ }^{3}$}

\section{Puzzle $e^{4}$}

(Conte)

À une date lointaine de l'ère chrétienne, hier, comme dirait l'autre, ou, si vous le souhaitez, en l'an trois mille et des poussières de la chronologie égyptienne, il arriva ce que je vais vous rapporter : l'histoire d'une famille que nous transmet un papyrus écrit en superbes fantoches. Là se trouve l'histoire en question, ou le fait divers d'une insignifiance notable, si le lecteur ne sait pas dépasser la partie graphique du texte; mais après s'être frotté les yeux sur le papyrus pendant de nombreux siècles, il n'est pas difficile d'en découvrir la substantifique moelle.

Voyez-vous...je dis bien que ce jour-là ou cet après-midi-là, ou disons plutôt ce soirlà, trois personnes et un âne cheminaient à travers les plaines d'Égypte, dans la région appelée Djebel Ezzrit (faisons preuve d'érudition !). L'âne servait de monture à une belle jeune femme qui portait un enfant dans ses bras; un vieil homme à l'air grave marchait

2 Expresión que nos hemos atrevido a traducir por «substantifique moelle», haciendo un guińo a Rabelais. Como lo recuerda Josette Blanquat, en “¿Galdós, humanista?» (Actas del I Congreso Galdosiano, 1977, pp. 43-59), don Benito leyó Gargantúa y Pantagruel en la edición ilustrada por Gustavo Doré de 1854. En la introducción a dicha obra, el humanista francés del siglo XVI, introduce la célebre metáfora en el prólogo de Gargantúa.

3 Fuente del texto original: Pérez Galdós (2004: 293-298).

4 Le conte de Benito Pérez Galdós Rompecabezas a été publié le 3 janvier 1897 dans le journal madrilène El Liberal. 
à ses côtés, brandissant un bâton qui lui servait à la fois pour battre le bourricot et alléger son pas lourd. On se rendait vite compte qu'ils étaient des fugitifs cherchant refuge dans ces contrées contre des persécuteurs d'autres pays, car, sans s'arrêter plus longtemps qu'il ne le fallait pour reprendre des forces, ils choisissaient, pour faire une halte, des endroits dissimulés, des cavités dans des roches isolées, ou encore des fourrés épais, des lieux fréquentés par les animaux sauvages plutôt que par les hommes.

Il est impossible de reproduire ici l'intensité poétique avec laquelle l'écriture figurative décrit ou plutôt dépeint la beauté de la mère. Vous ne pourrez ni l'apprécier ni la comprendre en imaginant la substance des lys qui, cuivrée et dorée par le soleil, conserve sa pureté idéale. Du magnifique bébé, on peut dire uniquement qu'il était humainement divin, et que ses yeux résumaient tout l'univers, comme s'ils étaient la mystérieuse convergence du ciel et de la terre.

Ils marchaient, comme je l'ai dit, en pressant le pas, évitant les villages et ne faisant de haltes pour mendier que dans les bourgs et les hameaux habités par des gens pauvres. Comme les bonnes âmes ne manquaient pas dans cette région du monde, ils purent progresser, non sans peine, dans leur prudente marche, et parvinrent finalement à l'orée d'une très grande ville aux gigantesques murailles et aux monuments prodigieux, qui, de loin, égayaient les pauvres pèlerins et leur coupaient le souffle. L'homme grave ne cessait d'estimer de telles merveilles; la jeune femme et l'enfant les admiraient en silence. La chance leur sourit, ou plutôt, L'Éternel Seigneur, incarné dans la bonté d'un ami, un marchand fortuné qui revenait de Thèbes accompagné de tout un cortège de serviteurs et d'un convoi de chameaux chargés de richesses. Le papyrus ne dit pas que l'homme était compatriote des fugitifs; mais sa façon de parler (cela ne veut pas dire que nous ayons pu l'écouter) semblait être celle de la région qui se trouve de l'autre côté de la mer vermeille. Les voyageurs racontèrent leurs fatigues et leur peines au généreux commerçant, et celui-ci les hébergea dans une de ses meilleures tentes, leur offrit des mets raffinés, et leur redonna du courage grâce à des conversations agréables et des récits de voyages et d'aventures, que le beau bébé écoutait gravement tout en souriant, comme les adultes écoutent les petits lorsqu'ils ont appris leur leçon. Quand ils firent leurs adieux, le marchand les assura que dans cette province de l'Égypte intérieure, ils devaient se considérer comme des personnes libres de toute persécution, puis il remit au vieil homme une poignée de pièces de monnaies; dans la menotte de l'enfant, il déposa une pièce en or qui devait être un doublon ou une double pistole reluisante, avec des légendes endiablées sur chaque face. Inutile de dire que cela provoqua une dispute familiale entre l'homme grave et la très belle maman, car le premier, agissant avec prudence et prévision pour l'économie familiale, pensa que la pièce serait bien plus en sécurité dans sa bourse que dans la main du petit; sa femme, pressant la menotte de son bébé et ne cessant de la baiser, déclara que ces petits doigts-là étaient un coffre sûr pour garder tous les trésors du monde.

Tranquilles et joyeux, après avoir laissé le bourriquot bien installé dans un logis des faubourgs, ils pénétrèrent dans la ville qui s’embrasait pour célébrer à ce moment-là des festivités spectaculaires : celles du couronnement ou serment d'un roi dont l'Histoire a 
oublié le nom ou devrait le faire. Sur une place, que le papyrus décrit hyperboliquement comme étant de la grandeur d'une de nos provinces, un immense bazar ou marché s'étendait d'un bout à l'autre. Il se composait de tentes ou baraques très tape-à-l'œil. L'animation et la clameur qui y régnaient ne sont en rien comparables à celles des foules bien plus limitées que nous connaissons chez nous. Çà et là, de riches tissus, de précieux bijoux, des métaux et de l'ivoire, des baumes par milliers, des objets sans fin, tous conçus en fonction de leur utilité ou des petites envies ; là encore, des mets exquis, des boissons, de l'encens, des narcotiques, des produits stimulants et des poisons pour tous les goûts ; la vie et la mort, la douleur charmante et la jouissance fébrile.

Infatigables, les fugitifs parcoururent une partie de l'immense étendue de la foire, et tandis que le vieillard regardait les échoppes l'une après l'autre, en quête de choses utiles pour dépenser la pièce de monnaie de l'enfant, la mère, moins réaliste peut-être, rêveuse et empreinte d'une immense tendresse, cherchait un objet pouvant servir de distraction au petit, une babiole, un jouet par exemple, car les jouets ont toujours existé, et dans l'Égypte ancienne on donnait aux enfants pour qu'ils s'amusent des pièces à emboîter pour former des pyramides, des sphinx et des obélisques tout mignons, des caïmans, des couleuvres de pacotille, des serpents, des canards et des démons couronnés.

Ils ne tardèrent pas à trouver ce que la sainte mère souhaitait. Quelle collection de jouets! Ces merveilles de l'industrie des joujoux n'avaient rien à voir avec ce qu'on connait de nos jours comme type de babioles qu'on nous propose chez nous. Sachez que six longues heures ne suffisaient point pour voir ce que contenaient les échoppes: des statuettes de dieux très sauvages et des hommes semblables à des oiseaux, des sphinx qui ne disaient pas papa maman, des momies pour trois sous qu'on ouvrait et refermait ; enfin ...impossible de tout raconter. Pour que rien ne manque, il y avait des théâtres avec des décorations de palais et jardins et des personnages comiques prêts à lâcher le bon mot; il y avait des prêtres en draps blancs portant des chapeaux difformes, des bœufs provenant de l'élevage d'Apis, des sifflets décorés de fleurs de lotus, des vestales à demi nues, et des militaires très beaux dans leurs armures, des casques, des croix et des calvaires, et un grand nombre d'objets offensifs et défensifs que l'art militaire a inventés durant des siècles et des siècles pour le loisir des grands et des moins grands et des petits.

Entre la dame et l'homme à l'air grave, se trouvait l'enfant qui donnait ses menottes à l'un et à l'autre, tout en emboîtant son pas inquiet et enjoué au rythme de celui des adultes.

Et à vrai dire, on aurait pu prendre ce prodigieux petit enfant pour un être surnaturel car, si dans les bras de sa mère il était si mignon et si petit comme un angelot de quelques mois, au contact de la terre, il grandissait mystérieusement, sans pour autant cesser d'être un enfant ; il marchait d'un pas léger et s'exprimait avec aisance et clarté. Son regard profond, tour à tour triste et gravement souriant, produisait, chez ceux qui le regardaient, confusion et trouble.

S'étant enfin mis d'accord sur la façon de dépenser l'argent, les parents demandèrent à l'enfant de choisir tous les beaux objets qui lui feraient vraiment plaisir. Le petit enfant regardait et observait attentivement et d'un air réfléchi, mais dès qu'il semblait se décider 
pour quelque chose, il changeait aussitôt d'avis et, après avoir désigné un poupon, il en désignait un autre, sans montrer une quelconque préférence. Son hésitation était, d'une certaine manière, angoissante, comme si, lorsque l'enfant avait des doutes, le cours inaltérable des choses restait en suspens dans toute la Nature. Finalement, après de longues hésitations, il sembla se décider. Sa mère l'aidait en lui disant : « veux-tu la guerre, des soldats? " et le vieil homme l'aidait également en lui disant : " veux-tu des anges, des prêtres, des petits bergers ? ». Et l'enfant répondait avec une grâce infinie, marmonnant un concept qui, traduit dans nos langues, signifiait : " de tout, beaucoup ».

Comme les figurines étaient bon marché, ils choisirent bien vite d'en emporter un grand nombre. Dans cette précieuse collection il y avait " de tout, beaucoup ", selon l'heureuse expression du petit enfant : des guerriers très arrogants qui, selon les traces laissées par l'Histoire, représentaient des chefs célèbres comme Gengis Khan, Cambyse, Napoléon, Annibal ; des saints et des soldats ermites barbus, des bergers avec des pelisses et d'autres figurines d'un réalisme incontestable.

Ils s'en furent allègrement vers leur auberge, suivis d'un essaim de petits garçons, avides de poser leurs mains sur le trésor dont la proportion était telle qu'il était réparti dans les mains des trois étrangers. L'enfant portait les plus jolies figurines et les serrait contre sa poitrine. Dès leur arrivée, la foule enfantine, qui n'avait cessé de s'agrandir au cours du chemin, entoura le propriétaire de toutes ces belles représentations de l'humanité.

Le fils de la fugitive les invita à jouer sur un terrain vague devant leur logis... Et ils jouèrent et s'agitèrent pendant si longtemps qu'on ne saurait le préciser, car cela durait de jour, puis de nuit et après la nuit venaient d'autres jours encore, si bien qu'on ne pourrait les compter. La merveille, dans ce jeu étrange où intervenaient des milliers d'enfants (un historien parle de millions), fut que le petit garçon, fils de la belle dame, utilisant les pouvoirs surnaturels dont il était certainement doté, transforma totalement les jouets-figurines qu'il possédait, en changeant toutes les têtes sans que nul n'en fut conscient ; ainsi les chefs apparurent avec une tête de bergers et les religieux avec une tête de militaires.

Vous auriez pu voir également des héros avec des crosses, des prêtres avec des épées, des religieuses avec des cithares, et en fin de compte tout ce que vous pourriez imaginer d'incongru. Il distribua ensuite son trésor à l'attroupement des enfants qui était devenu aussi considérable que toute une population ayant vécu sous de longs règnes.

Un garçon d'Occident bavard au teint hâlé reçut des petits curés entêtés et un bon nombre de guerriers sans têtes.

$1^{e r}$ janvier 1897

Benito Pérez Galdós 



\title{
CAPÍTULO IX
}

\section{Consideraciones sobre la traducción al inglés del cuento inédito Rompecabezas de Benito Pérez Galdós}

\author{
Lisa Nalbone \\ University of Central Florida, Estados Unidos
}

\section{INTRODUCCIÓN}

El cuento galdosiano «Rombecabezas», fechado el primero de enero 1897, figura en la portada del suplemento literario de El Liberal del 3 enero 1897, dedicado a la literatura juvenil. ${ }^{1}$ La colección de escritos está encabezada por «Los nińos» de Concepción Arenal, ensayo, en su primera lectura, sobre la importancia de los juguetes para los niños, pero que también esclarece distinciones de clase con respecto al acceso a los objetos de ocio. ${ }^{2}$ Después de la primera lectura literal de "Rompecabezas», es decir, un niño precoz que viaja por tierras remotas, recibe de regalo unas monedas con las cuales compra una colección de juguetes en forma de figurines de guerreros y sacerdotes, e intercambia las cabezas y los cuerpos y con estas recreaciones juega con una multitud de niños, le sigue la segunda lectura, tan importante en el ensayo de Arenal como en los cuentos que le siguen en este número especial de El Liberal, la cual apunta a la alegoría religiosa en los primeros dos tercios del cuento y que luego, en el último tercio, adquiere un tono po-

1 Las demás obras creativas, de varios géneros literarios, incluyen los cuentos «El caballero del Azor», de Juan Valera, «Manolín», de Eusebio Blasco, «Ternuras de la muerte», de José Echegaray, «Los niños», de Kasabal (seud. José Gutiérrez Abascal), «La paz», de Emilia Pardo Bazán, «En vela», de Sinesio Delgado, «Cosas de ángeles», de Jacinto Octavio Picón, «La oruga», de Isidro Fernández Flórez, y «Candelitas», de Rafael Salillas. Hay cuatro poemas: «Viendo morir a un niño», de Manuel del Palacio, «Rayo del sol», de Manuel Reina, «Los nietos», de Vital Aza, y «Víspera de Reyes», de Felipe Pérez y González. Aparecen también los diálogos «El abuelo y el padre», de Enrique Pérez Escrich, y «El hogar frío", de Constantino Gil. El suplemento incluye seis ensayos de temático juvenil: dos sin firmar (dedicados a «D. Lucas Zapatero y Moreno» y «Dońa Margarita Ferber»), «Estudio del niño», de Manuel B. Cossío, «El rey de la casa», de Manuel de Tolosa Latour, «Ternuras», de A. [Ángel] Pulido, y «La enseñanza materna», de José Zahonero. Las restantes dos páginas contienen noticias que en su mayoría informan sobre diferentes sucesos relacionados con la guerra en Cuba y Filipinas.

2 La primera versión de este ensayo, de extensión más larga y con dos párrafos introductorios diferentes, aparece como ensayo en las Obras completas (vol. 29, 1900) de Concepción Arenal con el título «Juguetes para niños», con fecha del 1 mayo 1876, Gijón. 
lítico. El cuento ha sido clasificado como uno de los doce relatos galdosianos fantásticos, término este en el sentido que lo emplea Tzvetan Tódorov. La cualidad autorreflexiva de «Rompecabezas» subraya la existencia de dos narratarios, los adultos y también sus hijos que leen por su propia cuenta o bien escuchan el cuento narrado, como ha seńalado Ramón F. Lloréns García con respecto a las lecturas de este suplemento (273).

Tanto los que leen el cuento, como los que lo escuchan reconocerían las semejanzas entre el niño de la historia de Galdós y el Niño Jesús, protagonismo señalado por la crítica primero por Leo J. Hoar (1975: 522-547) y luego ampliado por Alan Smith (1992: 20). El encanto, y el éxito, del cuento se puede atribuir a su composición que sigue «las reglas» de la literatura juvenil elaboradas por Remedios Sánchez García (2003: en línea) siguiendo a Emili Teixidor: «búsqueda de la identidad por parte del protagonista, implicación del lector en esa búsqueda, utilización de fórmulas de literatura popular, respeto a la edad de los lectores, presentación adecuada de los misterios de la vida, apuntes éticos sobre formas de vida».

Esto hace eco a la importancia del mito como estructura popular en la literatura destinada a los lectores jóvenes que elabora José Ortega y Gasset: «El mito, la noble imagen fantástica, es una función interna sin la cual la vida psíquica se detendría paralítica» (295).

En cuanto a la recepción del cuento, los niños — los narratarios explícitos- quedarían fascinados con la representación del protagonista fantástico que paulatinamente crece de su infancia hasta madurarse y convertirse en niño, y que al final del cuento está rodeado de otros niños deleitándose con los numerosos juguetes. Poseer un sinfín de juguetes es el sueño de muchos niños (de ahí la conexión con el ensayo de Arenal) y la magia que el niño precoz emplea para reconfigurar las figuras con que juega exige suspender la incredulidad no tanto para recrear el ambiente exótico sino para visualizar las incongruencias de cuerpos y cabezas de los juguetes.

Smith (1992: 198), coincidiendo con Hoar, comenta el significado alegórico del cuento al considerar el giro religioso-político entre los primeros dos tercios del cuento en que se recuenta la historia bíblica de María, José y Jesús que se desemboca en el último tercio del cuento, una transición a la lectura histórica en que la representación el Niño Jesús adquiere un nuevo significante: el rey Alfonso XIII. Como bien mencionan Smith y Hoar, dos elementos textuales adicionales aluden a esta lectura alegórica de «Rompecabezas»: la invitación del narrador al principio del cuento a "pasar de las exterioridades del texto gráfico» tras un período de "un par de siglos» y la referencia al «viejo pastor», epíteto para referirse a Práxedes Mateo Sagasta. Fue este una figura política decisiva en el poder menguante del Partido Liberal tras las elecciones de 1896 (12 y 26 abril). Se leía en la prensa del momento sobre los errores y defectos de Sagasta en la campaña pro-España en Cuba, especialmente en diciembre 1897, recordando en particular el fracaso de la política de reconcentración (febrero 1896-octubre 1897) del general Valeriano Weyler para suprimir la ola independentista en la isla con la reubicación de miles de campesinos en campamentos de concentración donde vivían en condiciones paupérrimas. La conexión entre Sagasta como figura histórica y Sagasta como figura literaria en el cuento de Galdós se observa mediante la transformación del hombre político que se fue perdiendo el poder y que ahora está sujeto a las maniobras, por no decir manipulaciones, del niño que representa Alfonso XIII. 
Galdós convierte este cuento expresamente para los niños en un arma propagandística, en un juego magistral que prefigura la pérdida de España de las últimas colonias. Aunque el autor no llega al extremo de manipular a los padres a adoctrinar a sus hijos contra los peligros de una agenda demasiado liberal al facilitar la lectura con ellos o por ellos, Galdós crea un doble código literario que permite hacer sentido de lo inverosímil del intercambio de cabezas y cuerpo. A la vez, Galdós consolida el modelo cronotópico que se remonta a un pasado alegórico para contextualizar su presente.

\section{TRADUCCIÓN DEL CUENTO AL INGLÉS}

\section{Braintwister $^{3}$}

(Short story)

What I am going to relate, a familiar story that a papyrus conveys to us written in the finest of drawings, happened yesterday, as we say, the year Such of the Christian Era, corresponding to Which, or if you prefer, some three thousand following Egyptian chronology. It is the same story or account of notorious insignificance, if the reader does not know how to glide over the exteriors of the graphic text; but rubbing one's eyes before it after a couple of centuries, it is not difficult to discover the crux of what it contains.

Well, reader ... I say that that day or that afternoon, or let's say night, three people and a donkey were traveling through the plains of Egypt, in the region they call Djebel Ezzrit $^{4}$ (to be scholarly). A beautiful young woman, astride the donkey, held a child in her arms; on foot, next to her, walked a serious old man, gripping a stick, which he also used to whip the donkey to keep steady its weary pace. Soon they were known to be fugitives, who sought refuge in those lands, against persecutors from another country, because without stopping more than necessary to regain their strength, they chose for their rest hidden places, hollows in solitary rocks, or thick bushes, more frequented by beasts than by men.

It is impossible to reproduce here the poetic intensity with which the drawings describe or rather paint the beauty of the mother. You could not appreciate and understand it by imagining the substance of lilies, which toasted and browned by the sun, retains its ideal purity. Of the precious little boy, it can only be said that he was humanly divine, and that his eyes encapsulated the entire universe, as if they were the mysterious convergence of heaven and earth.

They walked, as I said, hurriedly, dodging the villages and stopping only in hamlets or villages of poor people, to beg for alms. Since good souls were not scarce in that part of the world, they were able to journey forward, not without hardships, in their cautious march, and at last they came to the edge of a huge city of gigantic walls and colossal

3 The text, without edits, appears on the front page of El liberal, 3 January, 1897. For a contemporary edition, see Pérez Galdós (2004: 293-298).

4 I have not been able to identify this place, although Djebel means mountain in Arabic. 
monuments, whose distant sight amused the weary wanderers and lifted their spirits. The serious man did not cease to ponder such wonder; the woman and the boy admired them in silence. They were granted by luck, or rather, by the Eternal Lord, a good friend, a wealthy merchant, who was returning from Thebes with countless servants and a herd of camels loaded with riches. The papyrus does not say that he was from the same place as the fugitives; but by his manner of speaking (and this does not mean we heard it), it was known that he was from the lands that fall on the other side of the Red Sea. The travelers told the generous merchant of their adversities and their hardships, and he housed them in one of his best tents, gave them excellent delicacies, and tried to lift their dejected spirits with pleasant conversation and stories of travel and adventure, to which the precious child happily and attentively listened, as adults listen to children, when the little ones show that they understand their lessons. When he said goodbye, assuring them that in that interior province of Egypt they should be considered free from persecution, he gave the old man a handful of coins, and in the child's hand he put a gold one, which was shining and which must have been half an ounce or a doubloon, with devilish inscriptions on both sides. Needless to say, this prompted a family dispute between the serious man and the beautiful mother, since he, acting with prudence and financial foresight, believed that the coin was safer in his purse than in the little boy's hand, and his wife, clenching her son's fist and kissing it again and again, declared that those fingers were a safe coffer to keep all the treasures of the world.

Calm and joyful, after leaving their donkey comfortably sheltered in an inn at the outskirts of the village, they went into the city, which at the time was lit aflame for spectacular festivities for the coronation or swearing in of a king, whose name is forgotten or that history should forget. In a square, which the papyrus describes hyperbolically as the size of one of our provinces, an immense bazaar or market sprawled from end to end. It consisted of very attractive shops or stands, and for the liveliness and bustle that reigned in them, the small crowds in our civilization make it hard to imagine. There were very rich fabrics, precious jewels, metals and ivories, a thousand balsamic drugs, endless objects built for utility or whim; there were delicacies, drinks, incenses, drugs, soporifics, stimulants and poisons for all tastes; life and death, pleasant pain and feverish joy.

The fugitives, tireless, traveled through part of the immense fair, and while the old man looked at all the stands one by one, with eyes of practical watch, searching for something for which to put the child's money to use, the mother, perhaps less practical, dreamy, and overcome by great tenderness, was looking for some object that could be used to delight the creature, a frivolity, any sort of toy, as toys have always existed, and in ancient Egypt children entertained themselves with pyramids they could build, with enthralling sphinxes and obelisks, and alligators, lizards, snakes, ducks and demons donning crowns.

They soon found what the blessed mother wanted. Oh! What a collection of toys! We cannot imagine what it would be worth now at the time of writing, this interesting article, compared to those wonders of toy manufacturing. Suffice it to say that not even 
in six long hours could one see everything for sale in the stores: figurines of uncivilized gods, and men like birds, sphinxes that did not say daddy and mommy, cheap mummies that could be wrapped and unwrapped; at any rate ... it is impossible to keep count. So as not to leave anything out, there were theaters with decorations of palaces and gardens, and comedians hamming it up; there were priests with white frocks and misshapen hats, oxen from the Apis cattle breed, whistles adorned with lotus flowers, scantily clad priestesses, and dazzling military men with armor, helmets, crosses and cavalry, and all sorts of offensive and defensive gadgets that military artistry of all times had ever invented to entertain young and old.

\section{III}

In between the lady and the serious man walked the little boy, shaking one person's hand after another, and keeping his restless and playful step with the measured pace of the adults.

And indeed, that prodigious child could well be considered supernatural, because if in his mother's arms he was ever so tender and very little, like a months-old angel, when he stepped on the ground he grew mysteriously, although he was still a child; he walked with a light step and spoke with free and clear speech. His penetrating gaze sometimes sad, at times grievously cheerful, left those who saw him confused and faint.

In the end, the parents agreed on how to use the coin, and told him to choose from those beautiful objects what was most to his liking. The boy looked and looked with thoughtful care, and when he seemed to decide on something, he changed his mind, and pointed to one figure after another, without ever showing decided preference. His hesitation was somewhat distressing, as if as that child was hesitating, a suspension of the unalterable course of things occurred throughout Nature. Finally, after much wavering, he seemed to decide. His mother helped him by saying: "Do you want war, soldiers?" And the old man also helped him, saying: "Do you want angels, priests, little shepherds?" And he answered with infinite grace, stammering over a concept that is translated to our language to mean: "Much of everything."

Since the figurines were inexpensive, they quickly chose many of them to buy. In the beautiful collection there was much of everything, according to the happy expression of the little boy; arrogant warriors, who by their features represented famous leaders, Genghis Khan ${ }^{5}$, Cambyses ${ }^{6}$, Napoleon ${ }^{7}$, Hannibal $^{8}$; saints and bearded hermits, shepherds with tufts of hair and other figures who looked convincingly real.

They joyfully departed for their inn, followed by a swarm of children eager to get their hands on that treasure, which, because it was so large, was distributed among the hands of the three outsiders. The boy carried the most beautiful figures, pressing them

5 Genghis Khan (1160?-1227), tartar general, founder of the first Mongolian empire, conqueror of China.

6 King of Persia, reigned from 529-521 a. C. Conqueror of Egypt.

7 Napoleon Bonaparte (1769-1821), French emperor (1804-1814).

8 Carthaginian general (247-182? a. C.) He invaded Italy, but not the capital. He returned to Carthage to defend it against Scipio Africanus and was defeated (202). He poisoned himself rather than turning himself over to the Romans. 
against his chest. Upon arrival, the crowd of children, which had grown along the way, surrounded the owner of all those handsome representations of humanity.

The foreigner's son invited them to play in a vast field in front of the house ... And they played and caused a ruckus for a long time, the length of which is unknown, as it was day, and night, and after the night, there were more and more days to come, too many to count. The wonderful thing about that strange game involving thousands of children (a historian speaks of millions), was that the little boy, the son of the beautiful lady, using the supernatural power that he undoubtedly possessed, made a total transformation of the toys, switching the heads of all of them, without anyone noticing, so that the rulers had heads of shepherds and the religious, heads of military figures.

You could also see heroes with a staff, priests with a sword, nuns with a zither, in all, whatever incongruities you could imagine. Having done this, he distributed his treasure among the young group of kids, which had become as numerous as the entire population of those expansive kingdoms.

A boy from the West, dark-haired, and very chattery, was given some little priests with big heads and not a few warriors without their heads.

After the author's signature, it is dated 1 January, 1897. 


\title{
CAPÍTULO X
}

\author{
Bibliografía general
}

\section{BiBLIOGRAFÍA GENERAL}

ACíN, Ramón. 2010. «Historia de los cuerpos mortales cuando se cruzan con la historia inmortal». Cuadernos Hispanoamericanos, 724. Madrid: Instituto de Cooperación Iberoamericana, pp. 81-89.

ACOSTA DE HESS, Josefina. 1988. Galdós y la novela de adulterio. Madrid: Editorial Pliegos. aguirre Carballeira, Arantxa. 2006a. Buñuel, lector de Galdós. Las Palmas de Gran Canaria: Cabildo de Gran Canaria.

— 2006b. «Galdós y Buñuel: Tristana». En Arencibia, Yolanda; Bahamonde, Ángel (eds.) Galdós en su tiempo. Santa Cruz de Tenerife: Parlamento de Canarias, pp. 167182 .

— 2009. «Galdós y Buñuel: correspondencias». En García Serrano, Federico (ed.) Luis Buñuel (1900-1983): suspiros y películas. Monografias del cine español. Madrid: Universidad Complutense.

ALBONETTI, Pietro (ed.) 1994. Non c’è tutto nei romanzi. Leggere romanzi stranieri in una casa editrice negli anni '30. Milán: Mondadori.

AMBRELLA, Bruno. 2011. «Le letture per gli operai edite da Treves: traduzioni e adattamenti». La Fabbrica del Libro. Bollettino di storia dell'editoria in Italia, 1, pp. 7-13.

ANDRENIO (seudónimo de Eduardo Gómez Baquero). 1918. Novelas y novelistas. Galdós, Baroja, Valle-Inclán, Ricardo León, Unamuno, Pérez de Ayala, Condesa de Pardo-Bazán. Madrid: Ed. de Saturnino Calleja.

ANDREU, Alicia G. 1979. «El intertexto folletinesco en Tormento». En Rico, Francisco (dir.); Zavala, Iris M. (coord.) Historia y crítica de la literatura española, vol. 5, t. 2: Romanticismo y Realismo. Barcelona: Editorial Crítica, pp. 315-320.

ARENCIBIA SANTANA, Yolanda. 2009. "Galdós y sus lectores: ediciones». Actas VIII Congreso Internacional de Estudios Galdosianos. Las Palmas de Gran Canaria: Cabildo de Gran Canaria, pp. 878-888. 
- 2020. Galdós, una biografía. XXXII Premio Comillas 2020. Barcelona: Tusquets Editores.

ARIZA GONZÁLEZ, Fernando. 2010. «Recepción de la narrativa española en la prensa diaria estadounidense (1870-1900)». Revista de Literatura, vol. 72. Madrid: Universidad CEU San Pablo, pp. 86-108.

ARMAS, Frederick de. 2015. «Pérez Galdós en la prensa americana a finales del siglo XIX: el caso de La estrella de Panamá». Los fundamentos de una época. Actas X Congreso Internacional de Estudios Galdosianos. Las Palmas de Gran Canaria: Cabildo de Gran Canaria, pp. 438-444.

ARNÁIZ AMIGO, Palmira. 1977. «Galdós, en los paisajes del centro y este de Europa». Actas Primer Congreso Internacional de Estudios Galdosianos. Las Palmas de Gran Canaria: Cabildo de Gran Canaria, pp. 34-42.

- 1993. «Los estudios galdosianos en Rumanía». Actas Cuarto Congreso Internacional de Estudios Galdosianos, vol. 2. Las Palmas de Gran Canaria: Cabildo de Gran Canaria, pp. 9-18.

BACCANI GIANI, Silvia. 19.06.1903. «Carta a Benito Pérez Galdós». En Epistolario galdosiano. Las Palmas de Gran Canaria: Casa-Museo Pérez Galdós.

— 15.07.1903. «Carta a Benito Pérez Galdós». En Epistolario galdosiano. Las Palmas de Gran Canaria: Casa-Museo Pérez Galdós.

— 12.10.1903. "Carta a Benito Pérez Galdós». En Epistolario galdosiano. Las Palmas de Gran Canaria: Casa-Museo Pérez Galdós.

— 20.11.1909. «Carta a Benito Pérez Galdós». En Epistolario galdosiano. Las Palmas de Gran Canaria: Casa-Museo Pérez Galdós.

— 2016. «Lettera di Silvia Baccani Giani». En Il Rumentaio (blog). Disponible en: http://rumentaio.blogspot.com/2016/05/r042-lettera-di-silvia-baccani-giani.html.

BAES, Jan. 2000. [Reseña de Fortunata en Jacinta]. De Leeswolf, 10. Disponible en: https://www.mkw-uitgevers.nl/pefo.html.

— 2005. «De engel der armen». De Leeswolf. 2, pp. 100-101. Disponible en: https:// www.mkw-uitgevers.nl/pemd-lw.pdf.

- 2013. [Reseña de Miauw]. De Leeswolf. Vlabin-VBC20031231. Disponible en: http://zoeken.gent.bibliotheek.be/detail/Benito-Perez-Galdos/Miauw-roman/Bock/ ?itemid=\%7Clibrary\%2Fmarc\%2Fvlacc\%7C2554825.

BAKER, Mona. 1997. In Other Words. A Coursebook on Translation. Londres y Nueva York: Routledge, pp. 10-81.

BALLESTEROS DORADO, Ana Isabel. 2017. «Panorama de escritores españoles contemporáneos traducidos al italiano (1850-1914)». En Freire López, Ana María; Ballesteros Dorado, Ana Isabel (eds.) La literatura española en Europa (1850-1914). Madrid: UNED, pp. 41-70.

BarjaU, Teresa; Parellada, Joaquim. 2007. «Noticia de Benito Pérez Galdos y Tormento». En Benito Pérez Galdós, Tormento. Clásicos y Modernos, 20. Barcelona: Editorial Crítica, pp. 7-127. 
BARONI, Giorgio. 2012. «La ricezione della letteratura spagnola in alcune riviste italiane della prima metà del Novecento». En Camps, Assumpta (ed.) La traducción en las relaciones italo-españolas: lengua, literatura y cultura. Barcelona: Publicacions de la Universitat de Barcelona, pp. 55-74.

BARRILI, Anton Giulio. (1877/1879). Een Romeinsch ridder: uit het Italiaansch door M. A. de G. vertaald onder toezicht van H. Mulder. 's-Gravenhage: D. A. Thieme.

BASANTA, Ángel. 2011. «Almudena Grandes. Inés y la alegría. Tusquets, Barcelona, 2010». Campo de Agramante, 15. Jerez de la Frontera, Cádiz: Fundación Caballero Bonald, pp. 150-153.

BECERRA MAYOR, David. 2013. «Episodios de una guerra interminable de Almudena Grandes: ¿novelas de la memoria histórica?». Kamchatka, 2. Valencia: Universitat de València, pp. 241-270.

BELLONI, Benedetta y CRIPPA, Francesca. 2018. «Il patrimonio del fondo Gasparetti dell'Università Cattolica di Milano e l'importanza della sua eredità culturale per l'ispanismo italiano». En Rosso, Maria; Gambin, Felice; Calabrese, Giuliana; Cattaneo, Simone (eds.) Trayectorias literarias hispánicas: redes, irradiaciones y confluencias. Roma: ASIPI Edizioni, pp. 437-449.

BENEDETTI, Amedeo. 2014. "Angelo de Gubernatis nelle lettere agli amici letterati». Lares, 80, 2, 305-336.

BENíTEZ, Rubén. 1985. «Jenara de Barahona, narradora galdosiana». Hispanic Review, 53 (3). Filadelfia: University of Pennsylvania Press, pp. 307-327.

- 1990. Cervantes en Galdós (literatura e intertextualidad). Colección Maior, 35. Murcia: Universidad de Murcia.

- 1992. La literatura española en las obras de Galdós. Función y sentido de la intertextualidad. Colección Maior, 53. Murcia: Universidad de Murcia.

BENJAMIN, Walter. 1921. «Die Aufgabe des Übersetzers» [ensayo incluido en sus obras completas] Gesammelte Schriften IV, 1974, Fráncfort del Meno, pp. 9-21.

BERGAMín, José. 1957. La corteza de la letra. Buenos Aires: Losada.

Berkowitz, H. Chonon. 1948. Pérez Galdós, Spanish Liberal Crusader. Madison, WI: University of Wisconsin Press.

BEYRIE, Jacques. 1980. Galdós et son Mythe. Volumen II. París: Honoré Champion.

— 1987. «Trasfondo psicológico y fuentes íntimas de la novelística galdosiana: el caso de la segunda serie de Episodios». Boletín de la Biblioteca de Menéndez Pelayo, 63. Santander: Biblioteca de Menéndez Pelayo, pp. 213-232.

BIANCHINI, Angela. 1993. «Prefazione». En Pérez Galdós, Benito Donna di denari. Traducción de Elena Clementelli. Milán: Frassinelli, pp. V-IX.

BIKANDI MEJÍAS, Aitor. 1997. Galaxia textual: cine y literatura. Tristana: Galdós y Buñuel. Madrid: Pliegos.

BILLIANI, Francesca. 2004. "Traduzione e identità nazionale nell'Italia degli anni Venti e Trenta", La fabbrica del libro, 2. Disponible en: http://www.fondazionemonda dori.it/cms/culturaeditoriale/195. 
BLANQUAT , Josette. 1977. «¿Galdós, humanista?». En Arencibia, Yolanda; del Prado Escobar, María; Quintana, Rosa María (eds.) Actas Primer Congreso Internacional Galdosiano. Las Palmas de Gran Canaria: Cabildo de Gran Canaria, pp. 43-59.

BLY, Peter. 2009. «Galdós y los críticos europeos». En Arencibia, Yolanda; Prado Escobar; María del; Quintana, Rosa María (eds.) Galdós y el siglo XX. Actas VIII Congreso Internacional de Estudios Galdosianos. Las Palmas de Gran Canaria: Cabildo de Gran Canaria, pp. 816-832.

BOON, Adri. 2000. «Nawoord». En Benito Pérez Galdós, 1887/2000, pp. 585-597.

— 2001a. «Nawoord». En Benito Pérez Galdós, 1884 /2001a, pp. 299-303.

— 2001b. «Nawoord». En Benito Pérez Galdós, 1884 /2001b, pp. 252-256.

— 2002. «Nawoord». En Benito Pérez Galdós, 1888/2002, pp. 323-328.

BRaVo-Villasante, Carmen. 1970. Galdós visto por sí mismo. Colección Novelas y Cuentos. Madrid: EMESA.

BRIGANTI, Andrea. 2014a. «Las preguntas de un traductor: cartas de Gilberto Beccari a Miguel de Unamuno». Cuadernos AISPI, 3, pp. 41-58.

— 2014b. «Gilberto Beccari, traduttore professionista». En Dolfi, Laura (ed.) Tradurre il Novecento, Parma: MUP, pp. 198-217.

BROCH, Hermann. [1948] 1994. "Algunas consideraciones sobre la filosofía y la técnica del traducir», en Vega, Miguel Ángel (ed.) Textos clásicos de teoría de la traducción. Traducción de Miguel Ángel Vega Cernuda. Madrid, Cátedra, pp. 310-323.

BRUYKER, Christ de. 1965. De geschiedenis van de Multatulikring Gent van zijn stichting af tot 1940. Gent: S. M. Het Licht.

BUIJS, Marian. 1993. "Brokkelige Miau gaat verloren in te breed opgezette enscenering». De Volkskrant, 13-3-1993, p. 13. Disponible en: http://resolver.kb.nl/resolve?urn= ABCEEE:010866286:MPEG21:0013.

BURTSCHEIDT, Andreas. 2019. «Edmund Freiherr Raitz von Frentz. Rom Korrespondent der deutschsprachigen katholischen Presse 1924-1964». Veröffentlichungen der Kommission für Zeitgeschichte, 112. Disponible en: https://brill.com/view/title/460 63? format=HC\&language $=$ en.

BUSH, Peter. 1979. "Galdós and the French Traslation of La campaña del Maestrazgo». Anales Galdosianos, XIV, pp.119-124.

CAISTOR, Nick. 2010. «Estridencias». Revista de Libros. Segunda Época, 168. Disponible en: https://www.revistadelibros.com/articulos/ines-y-la-alegria-novela-de-almudena grandes.

CALDERÓN PUERTA, Aránzazu. 2017. «La historia en clave emocional en Inés y la alegría de Almudena Grandes». Studia Romanica Posnaniensia, 44 (2). Poznań: Adam Mickiewicz University Press, pp. 7-19.

CANAL, Jordi. 2004. El carlismo. Dos siglos de contrarrevolución en España. Madrid: Alianza.

CANALES y TORO, Clemente. 1960. Canción nacional de Chile. Edición de la letra. Santiago de Chile: Andrés Bello.

CÁNOVAS SÁnCHEZ, Francisco. 2019. Benito Pérez Galdós: vida, obra y compromiso. Madrid: Alianza Editorial. 
CARDONA DE GIBERT, Ángeles. 1980. «Cataluña y Galdós». Actas Segundo Congreso Internacional de Estudios Galdosianos, vol. 2. Las Palmas de Gran Canaria: Cabildo de Gran Canaria, pp.151-163.

CARDWELL, Sarah. 2018. «Pause, rewind, replay: adaptation, intertextuality and (re) defining adaptation studies». En Cutchins, Dennis; Krebs, Katja; Voigts, Eckart (eds.) The Routledge Companion to Adaptation. Londres y Nueva York: Routledge, pp. 7-17.

CARRAZÓN, Juan Carlos. 2007. «Entrevista al profesor Dong Yansheng». Isidora: Revista de Estudios Galdosianos, n. ${ }^{\circ}$ 5. Madrid, pp. 165-174.

CASALDUERO, Joaquín. 1943. Vida y obra de Galdós (1843-1920). Buenos Aires: Losada.

- 1951. Vida y obra de Galdós (1843-1920). Madrid: Gredos.

- 1970. «Auguste Comte y Marianela». Vida y obra de Galdós (1843-1920). Madrid: Gredos, pp. 204-221.

CASTAÑEDA HERNÁNDEZ, María del Carmen. 2011. «Literatura y memoria». Hipertexto, 14. Edinburgh, Texas: The University of Texas Pan-American, pp. 148-154.

CASTRESANA, Luis. 1959. «Inleiding». En Spaanse verhalen. Utrecht: Het Spectrum, pp. 7-10.

CEMBALI, Maria Elena. 2006. «I traduttori nel Ventennio fascista fra autocensura e questioni deontologiche», Intralinea, 8. Disponible en: http://www.intralinea.it/volumes leng_more.php?id=474_0_2_0_M\%25.

CHAMBERLIN, Vernon A. 1977. «El interés soviético por los episodios y novelas de Galdós» (1935-1840). Actas Primer Congreso Internacional de Estudios Galdosianos. Las Palmas de Gran Canaria: Cabildo de Gran Canaria, pp.144-151.

CLAVERÍA, Carlos. 1957. «El pensamiento histórico de Galdós». Revista Nacional de Cultura, 121-122. Caracas: Ministerio de Cultura, pp. 170-177.

COMELLAS AGUiRREZÁBAL, Mercedes. 2010. «Entre historias fingidas y verdaderas: (el) Tormento de Galdós». En Nieto Nuño, Miguel (coord.) Literatura y comunicación. Madrid: Castalia, pp. 131-182.

CÚNEO Y VIDAL, Rómulo. 14.02.1879. «Carta a Benito Pérez Galdós». En Epistolario galdosiano. Casa-Museo Pérez Galdós.

CURCI, C. M. 1878/1879. De geschillen tusschen den Heiligen stoel en de moderne maatschappij. Traducido por P. du Buy. Haarlem: J. J. van Brederode.

DE GUbernatis, Angelo. 1898. L'Argentina. Ricordi e letture. Firenze: Bernardo Seeber.

DEMICHELIS, Giacomo. 2.10.1880. «Carta al director de La Guirnalda». En Epistolario galdosiano. Las Palmas de Gran Canaria: Casa-Museo Pérez Galdós.

— 23.11.1880. «Carta a Benito Pérez Galdós». En Epistolario galdosiano. Las Palmas de Gran Canaria: Casa-Museo Pérez Galdós.

DENDLE, Brian J. 1986. Galdós: The Early Historical Novels. Columbia, MO: University of Missouri Press.

DÍAZ LAGE, Santiago. 2017. «Tres críticos franceses de Emilia Pardo Bazán (1885-1886)».

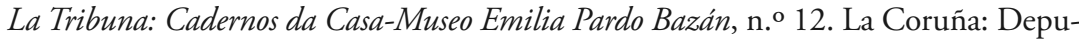
tación da Coruña, pp. 131-166. 
DÍAZ PÉREZ, Eva. 2010. «La España que pudo ser». Mercurio, 124. Sevilla: Fundación José Manuel Lara, pp. 26-27.

DONG, Yansheng. 2005. "La conjuración de las palabras (en chino mandarín)». Isidora. Revista de Estudios Galdosianos, n. ${ }^{\circ}$ 1, pp. 181-186.

DONGELMANS, Berry. 2008. «"Zoo zoude ik reeds lang voor de eer hebben bedankt". A. H. Adriani (1848-1930), de Leidse uitgever van G. J. P. J. Bolland». Omslag. Bulletin van de Universiteitsbibliotheek Leiden en het Scaliger Instituut, 10 (1), pp. 5-6.

ESCOBEDO, María. 2012. «Entrevista a Almudena Grandes». Cuadernos Hispanoamericanos, 744. Madrid: Instituto de Cooperación Ibeoramericana, pp. 127-135.

FREIRE LÓPEZ, Ana María; BALlesteros DORADO, Ana Isabel (eds.). 2017. La literatura española en Europa (1850-1914). Madrid: UNED.

FukUshima, Noriko. 2016. «E. Pardo Bazán. Los Pazos de Ulloa. Traducción al japonés por Eizo Ogusu». Tokyo: Ed. Gendaikikakushitsu, pp. 297-302.

GALEOTA, Vito. 1988. Galdós e Buñuel: romanzo, flim, narrativa in "Nazarin» e in "Tristana». Nápoles: Istituto Universitario Orientale.

GALFRÈ, Monica. 2005. Il regime degli editori. Libri, scuola e fascismo. Roma-Bari: Laterza. GARBISU BUESA, Margarita. 2017. «Las cátedras de español en Reino Unido (1). Oxford y Madariaga». Centro Virtual Cervantes. Rinconete. Literatura. Disponible en: https://cvc.cervantes.es/el_rinconete/anteriores/junio_17/08062017_01.htm.

GARCía BolTA, María Isabel. 1993. «Pérez Galdós fuera de España». En Actas Cuarto Congreso Internacional de Estudios Galdosianos, vol. 2, Las Palmas de Gran Canaria: Cabildo de Gran Canaria, pp. 45-56.

- 1995. Galdós editor. Santander: Ed. Tantín.

— 2001. «Prólogo al facsímil de Electra». Gobierno de Canarias.

GARCÍA PINACHO, María del Pilar. 2019. «Benito Pérez Galdós en Park Row: De topic a trending topic en la prensa neoyorquina (1883-1920)». La hora de Galdós. Actas XI Congreso Internacional de Estudios Galdosianos. Las Palmas de Gran Canaria: Cabildo de Gran Canaria, pp. 410-433.

— 2016. «El tiempo de Galdós. Benito Pérez Galdós en los diarios parisinos: Le Temps». Moenia: Revista Lucense de Lingüistica y Literatura, n. ${ }^{\circ}$ 22. Lugo: Universidad de Santiago de Compostela, pp. 63-99.

GENETTE, Gérard. 1982. Palimpsestes. La littérature au second degré. París: Seuil.

Gentili, Sandro; manghetTi, Gloria (eds.). 2003. Giovanni Papini - Giuseppe Prezzolini (eds.), Carteggio I, 1900-1907. Dagli "Uomini liberi» alla fine del "Leonardo", Roma: Edizioni di Storia e Letteratura-Biblioteca cantonale Lugano - Archivio Prezzolini.

GENTZLER, Edwin. 2017. Translation and Rewriting in the Age of Post-Translation Studies. London: Routledge.

GEORGE, David R., Jr. 2005. «Foresight, Blindness or Illusion? Women and Citizenship in the Second Series of Galdós's Episodios nacionales». En Larson, Susan; Woods, Eva (eds) Visualizing Spanish Modernity. Oxford: Berg, pp. 46-63. 
GIOVANNI. 1901. «Kunst en Wetenschappen. Hollandsche Schouwburg. Electra». Algemeen Handelsblad, 18-04-1901. Disponible en: http://resolver.kb.nl/resolve?urn= ddd:010647080:mpeg21:p010.

GODOY, Adèle. 1901a. «Electra». Algemeen Handelsblad, 09-04-1901, p. 6. Disponible en: http://resolver.kb.nl/resolve?urn=ddd:010647071:mpeg21:p006.

- 1901b. «Ingezonden stukken. Electra». Algemeen Handelsblad, 23-04-1901, p. 6. Disponible en: http://resolver.kb.nl/resolve?urn=ddd:010647085:mpeg21:p010.

— 1901c. «Electra». Algemeen Handelsblad, 01-05-1901, p. 10. Disponible en: http:// resolver.kb.nl/resolve?urn=ddd:010647449:mpeg21:p010.

GÓMEZ LÓPEZ-QUIN̄ONES, Antonio. 2006. La guerra persistente. Memoria, violencia, utopía: Representaciones contemporáneas de la Guerra Civil española. Madrid: Iberoamericana.

GÓMEZ MONTOYA, John Jairo. 2010. «De la translación a la traducción de Antoine Berman». Mutatis Mutandis: Revista Latinoamericana de Traducción, pp. 125-151. (Texto publicado con autorización de TTR: traduction, terminologie, redaction).

GÓMEZ PABLOS, Beatriz. 2017. «Panorama de la narrativa contemporánea española editada en alemán entre 1859 y 1914». En Ana María Freire López y Ana Isabel Ballesteros Dorado (eds.), La literatura española en Europa, 1850-1914. Madrid: Universidad Nacional de Educación a Distancia.

GONZÁLVEZ, Isabel; SEVILLA, Gabriel. 2008. «Introducción». En Pérez Galdós, Benito. Tristana. Letras Hispánicas, 627. Barcelona: Editorial Cátedra, pp. 9-113.

GRÄFENBERG, Selly. 1924. Spanisch: Brieflicher Sprach-und Sprech-Unterricht für das Selbststudium Erwachsener. Berlín-Schöneberg: Langenscheidt. Disponible en: http:// d-nb.info/365918245.

GRANDE, Luigi. 1901. “Elettra” di Pérez Galdós al "Manzoni” di Roma». En Rivista teatrale italiana, I, II, pp. 33-35.

GRANDES, Almudena. 2014a. Inés y la alegría. Barcelona: Tusquets Editores.

- 2014b. El lector de Julio Verne. Barcelona: Tusquets Editores.

- 2014c. Las tres bodas de Manolita. Barcelona: Tusquets Editores.

- 2017. Los pacientes del doctor García. Barcelona: Tusquets Editores.

GROOT, Ger. 2000. «Straf voor de Spaanse burger». NRC, 22-09-2000. Disponible en: https://www.nrc.nl/nieuws/2000/09/22/straf-voor-de-spaanse-burger-7511253a255129.

- 2001. «Dwalen in een Spaanse slangenkuil». NRC, 21-09-2001. Disponible en: https://www.nrc.nl/nieuws/2001/09/21/dwalen-in-een-spaanse-slangenkuil-75580 02-a 888893.

— 2003. «Spanje krijgt een schop». NRC, 30-05-2003. Disponible en: https://www. nrc.nl/nieuws/2003/05/30/spanje-krijgt-een-schop-7640855-a1320476.

GUAZZELLI, Francesco. 04.01.2010. «Tristana: un testo condiviso tra Galdós y Buñuel». la Repubblica.it. Disponible en: https://www.repubblica.it/speciale/2004/ biblioteca/ intro/galdos.html. 
GUINKO, Valentina. 1993. «Apuntes sobre la primera etapa galdosiana en Rusia (18971917)». Actas Cuarto Congreso Internacional de Estudios Galdosianos, vol. 2. Las Palmas de Gran Canaria: Cabildo de Gran Canaria, pp. 67-74.

GULLÓN, Germán. 1990. La novela del XIX : estudio sobre su evolución formal. Ámsterdam y Atlanta: Rodopi.

GULLÓN, Ricardo. 1960. Galdós novelista moderno. Madrid: Taurus.

— 1970. Técnicas de Galdós. Ensayistas de Hoy. Madrid: Taurus Ediciones.

- 1973. Galdós, novelista moderno. Biblioteca Románica Hispánica. II Estudios y Ensayos, 94. Madrid: Editorial Gredos.

H. 1890. «Nieuwe uitgaven en vertalingen. B. Perez Galdos. Marianela. Uit het Spaansch vertaald door Una. Leiden, A. H. Adriani». De tijdspiegel, 47 (3) p. 108. Disponible en: http://resolver.kb.nl/resolve?urn=KBDBNL02:004928003:00001.

H., J. 1903. «Zuster Marcela. Roman eener non, door B. Pérez Galdós. Uit het Spaansch. Leiden, A. H. Adriani». De tijdspiegel 3, p. 220. Disponible en: http://resolver.kb.nl/ resolve?urn=KBDBNL02:004942003:00001.

HAAN, Jacques den. 1975. "Victoriaans geschrijf. Tristana. Roman van Spaanse negentiende-eeuwer verteld». Het Parool, 20-09-1975, p. 9. Disponible en: http:// resolver.kb.nl/resolve?urn=ABCDDD:010840613:mpeg21:p009.

HATIM, Basil; MASON, Ian. 1995. Teoría de la traducción. Una aproximación al discurso, traducción de Salvador Peña, Barcelona, Ariel.

HeRnÁNDEZ suÁreZ, Manuel. 1972. Bibliografía de Galdós I. Las Palmas de Gran Canaria: Cabildo de Gran Canaria.

HERRERA NAVARRO, Javier. 1998. Bibliografía de estudios sobre Galdós. Investigaciones Bibliográficas sobre Autores Españoles, 2. Madrid: Fundación Universitaria Española.

HEYST, David François. 1885. «Dona Perfecta van D. Benito Perez Galdós, uit het Spaansch, door M. A. de G... Leiden, E. J. Brill». Het leeskabinet; mengelwerk tot gezellig onderhoud voor beschaafde kringen, 52, pp. 30-33. Disponible en: http://resolver. $\mathrm{kb} . \mathrm{nl} /$ resolve?urn=MMKB07:001244001:00007.

HINTERHÄUSER, Hans. 1963. Los «Episodios nacionales» de Benito Pérez Galdós. Madrid: Gredos.

Historisch ANTIQUariaAT A. G. VAN DER STEUR. 1992. Catalogus 12. Geschiedenis van het Nederlands toneel. Haarlem.

HOAR, Leo J. Jr. 1975. «"Rompecabezas”, Galdós’ Lost Cuento; a pre-98 Christmas Esperpento». Neophilologus, 59, pp. 522-547.

JACOBS, Monique. 2005. «Patrones van de hopeloze gevallen». 8Weekly, 18-05-2005. Disponible en: https://8weekly.nl/recensie/boeken/benito-pa-rez-galda-s-mededogenpatrones-van-de-hopeloze-gevallen/.

JIAN, HOU. 2017. Buitre o fénix: la traducción y la recepción de la obra de Mario Vargas Llosa en China. Tesis doctoral. Universidad de Huelva. Disponible en: http://rabida. uhu.es/dspace/handle/10272/13691.

JONG, Anneriek de. 1993. «De winnaars zijn de leugenaars. Miau opent nieuw Theater aan het Spui van Herzberger in Den Haag». NRC Handelsblad, 12-03-1993, p. 6. 
Disponible en: http://resolver.kb.nl/resolve?urn=KBNRC01:000030692:mpeg21: p006.

KESS, Alexandra. 1993. «Traducir a Galdós: ironía como elemento estilístico y conceptual de Tristana y la traducción rusa de 1987». Actas Cuarto Congreso Internacional de Estudios Galdosianos, vol. 2. Las Palmas de Gran Canaria: Cabildo de Gran Canaria, pp. 93-99.

KONIECZNA-TWARDZIKOWA, Jadwiga. 1995. «Los polacos en Miau. Problema de la traducción del estereotipo». Actas Quinto Congreso Internacional de Estudios Galdosianos, vol. 1. Las Palmas de Gran Canaria: Cabildo de Gran Canaria, pp. 109-124.

KONING, P. W. de. 1901a. «Kunst en Wetenschappen. Electra». Algemeen Handelsblad, 20-04-1901, p. 6. Disponible en: http://resolver.kb.nl/resolve?urn=ddd: 010647082: mpeg21:p010.

— 1901b. «Electra». Algemeen Handelsblad, 27-04-1901, p. 14. Disponible en: http:// resolver.kb.nl/resolve?urn=ddd:010647089:mpeg21:p018.

Kruger, Alet; WallmaCh, Kim; SANDerson, Penny. 2003. Translation and Editing Techniques. Pretoria: Department of Linguistics (Translation Studies) / University of South Africa, pp. 120-130.

LANSLOTS, Inge. 2000. «De Balzac van Madrid». De Financieel-Economische Tijd. Tijd Cultuur. 20.09.2000, p. 23.

LEMARTINEL, Jean. 1977. «Unas notas acerca de La Fontana de Oro». Actas Primer Congreso Internacional de Estudios Galdosianos. Las Palmas de Gran Canaria: Cabildo de Gran Canaria, pp. 367-375.

LEMM, Robert. 1974. «Benito Pérez Galdós». En Pérez Galdós 1892/1974, pp. 210-215.

LIEFHEBbER, Peter. 1993. «Miau van Guusje Eybers verzuipt in de ruimte». De Telegraaf, 15-03-1975, p. 9. Disponible en: http://resolver.kb.nl/resolve?urn=ddd:010691864: mpeg21:p009.

LLORÉNS GARCÍA, Ramón F. 2014. «Un suplemento de El Liberal en los inicios de la literatura infantil española». Anales, 26, pp. 257-274.

LÓPEZ, Ignacio Javier. 2014. La novela ideológica (1875-1880). La literatura de ideas en la España de la Restauración. Madrid: Ediciones de la Torre.

LÓPEZ JiMÉnEZ, Luis. 1990a. «El estreno de Electra en París». Actas Tercer Congreso Internacional de Estudios Galdosianos, vol. 2. Las Palmas de Gran Canaria: Cabildo de Gran Canaria, pp. 405-415.

— 1990b. «A. Germond de Lavigne, primer traductor al francés de B. Pérez Galdós». El Guiniguada. Las Palmas de Gran Canaria: Universidad de Las Palmas de Gran Canaria, pp. 287-296.

- 1991. "Marianela de B. Pérez Galdós, en francés». En Donaire, María Luisa; Lafarga, Francisco (eds.) Traducción y adaptación cultural: España-Francia. Oviedo: Universidad de Oviedo, Servicio de Publicaciones, pp. 359-367.

— 1993. «Bixio, bienintencionado traductor mediocre de Misericordia». Actas Cuarto Congreso Internacional de Estudios Galdosianos, vol. 2. Las Palmas de Gran Canaria: Cabildo de Gran Canaria, pp. 127-134. 
— 1995. «Las traducciones de Pérez Galdós en francés». En Lafarga, Francisco; Ribas, Albert; Tricás, Mercedes (coord.). Actas III Coloquio de la Asociación de Profesores de Filología Francesa de la Universidad Española (APFFUE). Barcelona: PPU, pp. 157-164.

LÓPEZ SERRANO, Fernando. 2013. «Breve historia de los estudios hispánicos en Suecia». Revista Hispanista Escandinava, n. ${ }^{\circ}$ 2. Lund: Universidad de Lund.

MANCINI, Maria Elena. 2006. «L'Archivio Laterza e la storia dell'editoria negli anni del fascismo", La fabbrica del libro, 1. Disponible en: http://www.fondazionemonda dori.it/cms/culturaeditoriale/195.

MARESTA, Werner. «Lettera di Silvia Baccani Giani». Il Rumentaio (blog). Disponible en: http://rumentaio.blogspot.com/2016/05/r042-lettera-di-silvia-baccani-giani.html.

MARTÍN GAITE, Carmen. 2007. Usos amorosos de la postguerra española. Barcelona: Anagrama.

MARTINO ALBA, Pilar. 2010. «La recepción de los Episodios nacionales en Alemania: El 19 de marzo y el 2 de mayo». En Blanco García, María Pilar (ed.) El Cid y la guerra de la Independencia: dos hitos en la historia de la traducción y la literatura. Madrid: Universidad Complutense de Madrid - Instituto Universitario de Lenguas Modernas y Traductores, pp. 55-66.

MASINI, Roberta. 2007. «Nel mondo femminile di Angelo De Gubernatis: la sua corrispondenza intima». En Contini, Alessandra; Scattigno, Anna (eds.) Carte di donne, II, Roma: Edizioni di Storia e Letteratura, pp. 145-160.

MENKEN, Paul. 2016. Spaanse Bibliotheek. Catalogus. Leiden: Menken, Kasander \& Wigman. Disponible en: https://www.mkw-uitgevers.nl/spaansebibliotheek.pdf.

MONCY GULlón, Agnes. 1977. «Fortunata y Jacinta en inglés». Actas Primer Congreso Internacional de Estudios Galdosianos. Las Palmas de Gran Canaria: Cabildo de Gran Canaria, pp. 376-381.

MONTESINOS, José F. 1968. Galdós. Vol. I. Madrid: Castalia.

MONTORO CANO, Estela del Rocío. 2014. «El hispanismo en Checoslovaquia». Romanica Olomucensia, 26 (1). Olomouc: Universidad Palacký, pp. 85-95.

MORENO HERNÁNDEZ, Carlos. 2007. Retórica y cursilería: notas a El amigo Manso de Galdós. Serie Literatura, 69. Valladolid: Universidad de Valladolid.

MOYA, Virgilio. 2000. La traducción de nombres propios. Madrid: Ed. Cátedra.

MUlLeR, P. N. 1872. «De gouden fontein. La Fontana de Oro por Don Benito Perez Galdos. Madrid, 1871». De Gids, 36 (3), pp. 480-517. Disponible en: https://www. dbnl.org/tekst/_gid001187201_01/_gid001187201_01_0014.php.

— 1877a. «Españolismo of Spanje bovenal». De Gids, 41 (1), pp. 503-531. Disponible en: https://www.dbnl.org/tekst/_gid001187701_01/_gid001187701_01_0063.php.

— 1877b. «Españolismo of Spanje bovenal». De Gids, 41 (2), pp. 501-520. Disponible en: https://www.dbnl.org/tekst/_gid001187701_01/_gid001187701_01_0085.php.

- 1879. «Gloria. Perez Galdós. Madrid». De Gids, 43 (1), pp. 217-252. Disponible en: https://www.dbnl.org/tekst/_gid001187901_01/_gid001187901_01_0011.php. 
MUNTEANU COLÁN, Dan. 1995. «Breve panorama de la hispanística rumana». Philologica canariensia, n. ${ }^{\circ}$ 1. Las Palmas de Gran Canaria: Universidad de Las Palmas de Gran Canaria, pp. 533.

— 2014. «La literatura española e hispanoamericana en Rumanía». Nexo, n.o 11. Santa Cruz de Tenerife: Instituto de Estudios Hispánicos de Canarias, pp. 4-12.

MUÑOZ MOLINA, Antonio. 2011. «El país de Galdós». Disponible en: http://elpais.com/ diario/2011/09/10/babelia/1315613536_850215.html.

NAREBSKA, Ilona. 2011. Panorama histórico de las traducciones de la literatura polaca publicadas en España de 1939 a 1975.Tesis doctoral. Alicante: Universitat d'Alacant. Disponible en: https://rua.ua.es/dspace/bitstream/Tesis_Narebska.

NAVARRETE, Ramón de. 2003. Galdós en el cine español. Madrid: T\&B Editores.

NAVARRO GONZÁLEZ, Alberto. 1990. «Galdós, autor de relatos de viajes». Actas Tercer Congreso Internacional de Estudios Galdosianos, vol. 2. Las Palmas de Gran Canaria: Cabildo de Gran Canaria, pp. 133-140.

NAVASCUÉS, Miguel. 1987. «Liberales y absolutistas: personajes novelescos en la segunda serie de los Episodios nacionales». Revista de Literatura, 49 (98). Madrid: CSIC, pp. 491-510.

NUEZ CABALLERO, Sebastián de la. 1986. «Marianela y los hermanos Álvarez Quintero: Epistolario». Anales Galdosianos, XXI, pp. 251-262.

- 1990. Biblioteca y archivo de la Casa-Museo Pérez Galdós. Las Palmas de Gran Canaria: Cabildo de Gran Canaria.

ODIJK, Ad. J. 1978. «Beproefde teksten in twee edities». De Volkskrant, 14/11/1978, p. 24. Disponible en: http://resolver.kb.nl/resolve?urn=ABCDDD:010882142:mpeg 21:p024.

OLEZA, Joan. 1996. «Un realismo posmoderno». Disponible en: https://www.uv.es/entre siglos/oleza/pdfs/realpost.PDF, pp. 1-11.

ONDELLI, Stefano; ZIANI, Paolo. 2013. «Per un censimento delle traduzioni in italiano nell'Ottocento. Risultati di uno spoglio del CLIO relativo al periodo 1880-1889». Rivista Internazionale di tecnica della traduzione, 15, pp. 83-107.

OOSTERHOLT, Frans. 2004. «Nawoord». En Pérez Galdós 1897/2004, pp. 324-336.

ORANJE, Hans. 1993. «Miau laat alle hoeken nieuw theater zien». Trouw, 13-03-1993, p. 23. Disponible en: http://resolver.kb.nl/resolve?urn=ABCDDD: 010821787: mpeg21:p023.

ORTEGA y GASSET, José. 1966. «El Quijote en la escuela». Obras Completas, t. II, Madrid: Revista de Occidente, Madrid, pp. 273-306.

ORTIZ ARMENGOL, Pedro. 1996. Vida de Galdós. Col. Filología. Barcelona: Editorial Crítica. - 2000. Vida de Galdós. Biblioteca de Bolsillo, 35. Barcelona: Editorial Crítica.

OTTAIANO, Marco. 2013. «Cronache di un incontro superficiale: Benito Pérez Galdós e la moderna editoria italiana». En Sinestesieonline, 6, II, pp. s. p. Disponible en: http://sinestesieonline.it/wp-content/uploads/2018/03/dicembre2013-06.pdf.

PAVESE, Cesare. 1968. Lettere 1926-1950. Turín: Einaudi. 
PAZ DE CASTRO, Elena de. 2014. "Galdós en italiano». Isidora. Revista de Estudios Galdosianos, n. ${ }^{\circ} 24$. Madrid, pp. 19-37.

- 2019. «La lectura de Galdós en Italia». En Arencibia, Yolanda; Gullón, Germán; Galván González, Victoria et al. (eds.) La hora de Galdós. Actas XI Congreso Internacional de Estudios Galdosianos. Las Palmas de Gran Canaria: Cabildo de Gran Canaria, pp. 818-832.

PÉREZ GALDÓs, Benito. 1871/1953. «De roman in de tram». Traducido por G. Evenhuis. En Luis de Castresana (ed.), Spaanse verhalen. Utrecht: Het Spectrum.

— 1871/1959. «De roman in de tram». En Luis de Castresana (ed.), Spaanse verhalen, Utrecht: Het Spectrum, pp. 16-35.

— 1876/1883. Dona Perfecta. Traducción de María Anna de Goeije. Leiden: Brill.

- 1878/1890. Marianela. Traducción de Una. Leiden: A. H. Adriani.

- 1878/1891. Leon Roch en familie. Traducción de P. du Buy. Leiden: A. H. Adriani.

— 1878/1905. «De blinde en zijne gids. Spaansche novelle van Perez Goldós». Tubantia. 02-02-1905, 04-02-1905, 11-02-1905, 18-02-1905, 04-03-1905, 11-03-1905, 1603-1905, 18-03-1905, 25-03-1905, 30-03-1905, 01-04-1905, 08-04-1905, 15-04-1905, 22-04-1905, 26-04-1905, 29-04-1905, 13-05-1905, 18-05-1905. Disponible en: https://www.delpher.nl/nl/kranten/results?query=\%22de+blinde+ en+zijne+gids\% 22\&page $=1 \&$ sortfield $=$ date $\&$ coll $=$ ddd.

- 1878/1998. Marianela. Traducido por Elly Bovée. Leiden: Menken Kasander \& Wigman.

- 1884. Tormento. Madrid: Imprenta y Litografía de La Guirnalda.

- 1884/2001a. Tormento. Traducido por Adri Boon. Leiden: Menken Kasander \& Wigman.

— 1884/2001b. Mevrouw Bringas. Traducido por Elly Bovée. Leiden: Menken Kasander \& Wigman.

- 1887/2000. Fortunata en Jacinta: het verhaal van twee echtgenotes. Traducido por Adri Boon. Leiden: Menken Kasander \& Wigman.

- 1888/1979. Miau. Traducido por Roelof G. Groeneboer. Utrecht: Het Spectrum. Prima Klassieken 24.

- 1888/2002. Miauw. Traducido por Adri Boon. Leiden: Menken Kasander \& Wigman.

— 1890. «Prólogo». En La sombra. «Celín», «Tropiquillos» $y$ «Theros». Madrid: La Guirnalda, pp. 5-6.

— 1892/1974. Tristana. Traducido por Robert Lemm. Ámsterdam: Uitgeverij De Arbeiderspers.

— 1897/2004. Mededogen. Traducido por Frans Oosterholt. Leiden: Menken Kasander \& Wigman.

— 1898/1905a. «Een episode uit den Carlistenoorlog. Naar het Spaansch, van Péres Galdós». Bataviaasch nieuwsblad. 02-05-1905, p. 13. Disponible en: http://resolver. $\mathrm{kb} . \mathrm{nl} /$ resolve?urn=ddd:011034636:mpeg21:p013. 
— 1898/1905b. «Een episode uit den Carlistenoorlog. Naar het Spaansch, van Pérez Galdós». Traducido por E. J. B. Soerabaijasch handelsblad. 29-05-1905, p. 1. Disponible en: http://resolver.kb.nl/resolve?urn=ddd:011088145:mpeg21:p009.

- 1899. La campaña del Maestrazgo. Madrid: Est. Tip. de la Viuda e Hijos de Tello. Disponible en: http://www.cervantesvirtual.com/portales/benito_perez_galdos/obravisor/la-campana-del-maestrazgo-0/html/.

- 1899/1903. Zuster Marcela. Roman eener Non. [Tr. de La campaña del Maestrazgo]. Leiden: A.H. Adriani.

- 1900. «La campańa del Maestrazgo», III serie de Los Episodios nacionales. Madrid: Imprenta Hortaleza 132, 127 pp. Disponible en: https://TheVirtualLibrary.org.

- 1901/1901. Electra. Drama in vijf bedrijven. Opgevoerd in het Teatro Español, 30 januari 1901.Traducido por S. Leiden: A. H. Adriani.

— 1902. Der Roman einer Nonne, Viena-Budapest: Verlag von Sachs \& Pollák. Disponible en: https://gutenberg.spiegel.de/buch/der-roman-einer-nonne-2740/1.

- 1941-1942. Obras completas. 6 vols. Introducción, biografía, bibliografía, notas y censo de personajes galdosianos por Federico Sainz de Robles. Madrid: M. Aguilar Editor.

— 1951. The Spendthrifts. Translated by Gamel Woolsey. Illustrated by Charles Mozley. The Illustrated Novel Library. Londres: Weidenfeld \& Nicolson.

- 1952a. Torment. Translated by J. M. Cohen. Illustrated by Charles Mozley. The Illustrated Novel Library. Londres: Weidenfeld \& Nicolson.

— 1952b. The Spendthrifts. Translated by Gamel Woolsey. Illustrated by Charles Mozley. The Illustrated Novel Library. Nueva York: Farrar Straus \& Young.

- 1953. Torment. Translated by J. M. Cohen. Illustrated by Charles Mozley. The Illustrated Novel Library. Nueva York: Farrar Straus \& Young.

— 1971. Tormento. El Libro de Bolsillo / Sección: Literatura. Madrid: Alianza Editorial.

- 1972. «Observaciones sobre la novela española contemporánea». En Bonet, Laureano (ed.) Ensayos de critica literaria. Barcelona: Península, p. 124.

- 1977. Tormento. Edición de Eamonn Rodgers. Pergamon Oxford Spanish Series. Oxford / Nueva York: Pergamon Press.

- 1982. Los artículos políticos en la "Revista de España», 1871-1872. Lexington, KY: Dendle y Schraibman.

- 1985. Tristana. Tormento. Barcelona: Mundo Actual de Ediciones.

- 1998a. Inferno. Translated and edited by Abigail Lee Six. Londres: Phoenix House.

- 1998b. «Rompecabezas». En Smith, Alan E. (ed.) Cuentos fantásticos. Col. Letras Hispánicas, 304. Madrid: Editorial Cátedra, pp. 293-298.

- 2005. Zaragoza. En Troncoso, Dolores; Varela, Rodrigo (eds.) Episodios nacionales. Primera serie. La guerra de la Independencia. Barcelona: Destino, pp. 659-781.

- 2007. Tormento. Edición de Teresa Barjau y Joaquín Parellada. Clásicos y Modernos, 20. Barcelona: Editorial Crítica. 
- 2008a. Tristana. Edición de Isabel Gonzálvez y Gabriel Sevilla. Letras Hispánicas, 627. Barcelona: Editorial Cátedra.

- 2008b. Tormento. Biblioteca de Autor / Biblioteca Pérez Galdós, BA 121. Madrid: Alianza Editorial.

- 2010. Montes de Oca. En Troncoso, Dolores (ed.) Episodios nacionales. Tercera serie. Cristinos y carlistas. Barcelona: Destino, pp. 999-1106.

- 2011a. Memorias de un cortesano de 1815. En Penas, Ermitas (ed.) Episodios nacionales. Segunda serie, I. Madrid: Biblioteca Castro, pp. 201-371.

- 2011b. La segunda casaca. En Penas, Ermitas (ed.) Episodios nacionales. Segunda serie, I. Madrid: Biblioteca Castro, pp. 375-586.

- 2012a. Los apostólicos. En Penas, Ermitas (ed.) Episodios nacionales. Segunda serie, II. Madrid: Biblioteca Castro, pp. 631-862.

- 2012b. Un faccioso más y algunos frailes menos. En Penas, Ermitas (ed.) Episodios nacionales. Segunda serie, II. Madrid: Biblioteca Castro, pp. 865-1095.

— 2012c. «Segundo prólogo a los Episodios nacionales. Edición ilustrada». En Penas, Ermitas (ed.) Episodios nacionales. Segunda serie, II. Madrid: Biblioteca Castro, pp. 1097-1106.

- 2013. La sociedad presente como materia novelable: discurso leido el día 7 de febrero de 1897 en el acto de su recepción pública en la Real Academia Española, y contestación de D. Marcelino Menéndez Pelayo. Discursos de Ingreso de la Real Academia Española, 3. Madrid: Biblioteca Nueva / Real Academia Espańola.

— 2016. Correspondencia. Madrid: Cátedra.

PERSYN, Jules. 1901. «Electra van Pérez Galdós». Dietsche Warande en Belfort. 2 (2), pp. 597-609.

POL, Barber van de. 1980. «Tussen humanisme en Jezus-beweging». NRC Handelsblad, 04-04-1980, p. 4. Disponible en: http://resolver.kb.nl/resolve?urn=KBNRC01:000 026763:mpeg21:p020.

POLIZZI, Assunta. 2007. "Traducciones y traiciones. El caso de Fortunata y Jacinta en Italia», Actas VI Congreso de Lingüistica General, vol. 1. Madrid: Editorial Arco/Libros, pp. 721-729.

- 2008. «Fortunata e Giacinta: estudio de una traducción». Isidora. Revista de Estudios Galdosianos, n. ${ }^{\circ}$ 6. Madrid, pp. 191-202.

- 2012. "Tradurre la palabra hablada: La diseredata de Galdós». Isidora. Revista de Estudios Galdosianos, n. ${ }^{\circ}$ 19. Madrid, pp.160-177.

RAGONE, Giovanni. 1999. Un secolo di libri. Turín: Einaudi.

RAMíreZ JÁIMEZ, Ana Sofía. 1993. "Crítica alemana sobre la obra de Galdós en el siglo XIX». Actas Cuarto Congreso Internacional de Estudios Galdosianos, vol. 2. Las Palmas de Gran Canaria: Cabildo de Gran Canaria, pp. 189-198.

— 1995. «La recepción de la obra de Galdós en Alemania a la luz de las traducciones». Actas $V$ Congreso Internacional de Estudios Galdosianos, vol. 2. Las Palmas de Gran Canaria: Cabildo de Gran Canaria, pp. 97-107. 
Regalado garcía, Antonio. 1966. Benito Pérez Galdós y la novela histórica española: 1868-1912. Madrid: Ínsula.

REISS, Katharina; VERMEER Hans J. 1996. Fundamentos para una teoría funcional de la traducción, traducción de Sandra García Reina; Celia Martín de León. Madrid: Ed. Akal.

RIVAS, Antonio. 2012. «El tratamiento literario del tiempo en la narrativa de Almudena Grandes». En Almudena Grandes. Grand Séminaire de Neuchâtel. 1-2 de junio de 2010. Sevilla: Université de Neuchâtel y Editorial Arco/Libros, pp. 79-92.

RODGERS, Eamonn. 1988. «Teoría literaria y filosofía de la historia en el primer Galdós». En Bly, Peter (ed.) Galdós y la historia. Ottawa: Dovehouse Editions, pp. 35-47.

RODRÍGUEZ, Alfred. 1967. An Introduction to the 'Episodios Nacionales' of Galdós. Nueva York: Las Américas.

RODRÍGUEZ MARÍN, Rafael. 1996. La lengua como elemento caracterizador en las «novelas españolas contemporáneas» de Galdós. Lingüística y Filología, 25. Valladolid: Universidad de Valladolid.

ROEST, Maarten. 2001. «Melodrama’s van de Spaanse Balzac». Trouw, 06-10-2001. Disponible en: https://www.trouw.nl/cultuur-media/melodrama-s-van-de-spaanse-balzac - b0eea088/?referer=https\%3A\%2F\%2Fwww.google.com\%2F.

ROMÁN, Isabel. 1993. La creatividad en el estilo de Galdós. Biblioteca Galdosiana. Las Palmas de Gran Canaria: Cabildo de Gran Canaria.

ROOY, Luc de. 2005. «De leugen gaat net als de kreupele op krukken». Babel. Maandblad van de Faculteit der Geesteswetenschappen van de UvA, marzo, p. 20. Disponible en: https://www.mkw-uitgevers.nl/pemd-bb.pdf.

RUBBi, Daniele. 16.07.1883. «Carta a Benito Pérez Galdós». En Epistolario galdosiano. Las Palmas de Gran Canaria: Casa-Museo Pérez Galdós.

RUIZ-FORNELLS, Enrique. 1971. "Benito Pérez Galdós y la crítica norteamericana». Cuadernos Hispanoamericanos, n. ${ }^{\circ}$ 250-252. Madrid, pp. 712-759.

RUNDLE, Christopher. 1999. «Publishing Translations in Mussolini’s Italy: a Case Study of Arnoldo Mondadori». Textus. Rivista dell'Associazione italiana di Anglistica, XII, 2, pp. 427-442.

- 2000. "The Censorship of Translation in Fascist Italy». The Translator. Studies in Intercultural Communication, 6, 1, pp. 67-86.

SÁNCHEZ, Francisco J. 2012. "Historical Memory in Post-Transition Narratives: Between the Canon and the Market». Hispanic Issues On Line, 11. Mineápolis, MN: University of Minnesota, pp. 178-195.

SÁNCHEZ GARCÍA, Remedios. 2006. "El caballero del Azor” de Juan Valera, un modelo válido de literatura juvenil decimonónica». Centro Virtual Cervantes. Disponible en: http://www.cervantesvirtual.com/obra/el-caballero-del-azor-de-juan-valera-modelovlido-de-literatura-juvenil-decimonnica-0/.

SANDERS, Julie. 2006. Adaptation and Appropriation. Londres y Nueva York: Routledge. SANTAMARÍA COLMENERO, Sara. 2011. "La novela de la memoria como novela nacional: El corazón helado, de Almudena Grandes, ¿̨nuevo episodio nacional?». En Saz, Ismael; 
Archilés, Ferran (eds.) La nación de los españoles. Discursos y prácticas del nacionalismo español en la época contemporánea. Valencia: Universitat de València, pp. 1-20.

SARTRE, Jean-Paul. 1967. ¿Qué es la literatura? 4. ${ }^{\mathrm{a}}$ ed. Buenos Aires: Editorial Losada. SCHLEIERMACHER, Friedrich. 2000/1813. Sobre los diferentes métodos de traducir. Traducción y comentarios de Valentín García Yebra. Madrid: Ed. Gredos.

SCHMUCK, Hilmar; GORZNY, Willi; GEILS Peter. 1982. Gesamtverzeichnis des Deutschprachigen Schrifttums (GV) 1700-1910. München: Saur Verlag.

SCHÜCKING, Levin S. 1969. El gusto literario. 3. a reimpresión. México. Fondo de Cultura Económica.

SCOTT, Clive. 2012. Literary Translation and the Rediscovery of Reading. Cambridge: Cambridge University Press.

SEIGWORTH, Gregory J.; GREGG, Melissa. 2010. «An Inventory of Shimmers». En Gregg, Melisa; Seigworth, Gregory J. (eds.) The Affect Theory Reader. Durham y Londres: Duke University Press, pp. 1-25.

SIEMERS, Maren. 1993. «Equivalencia pragmática de la novela Gloria con su traducción alemana del año 1880 del Dr. August Hartmann». Actas Cuarto Congreso Internacional de Estudios Galdosianos, vol. 2. Las Palmas de Gran Canaria: Cabildo de Gran Canaria, pp. 245-253.

SITNIAKOWSKY, I. 1979. «Nederlandse lezer werd verwend in 1979». De Telegraaf, 2912-1979, p. 15. Disponible en: http://resolver.kb.nl/resolve?urn=ddd:011200660: mpeg21:p017.

SMith, Alan E. 1992. Los cuentos inverosimiles de Galdós en el contexto de su obra. Anthropos: Barcelona.

— 2005. «Capítulo IV. Galdós y la historia de Pigmalion». En Smith, Alan E., Galdós y la imaginación mitológica. Crítica y Estudios Literarios. Madrid: Ediciones Cátedra, pp. 89-108.

— 2009. «La recepción de la primera edición de Los desastres de la guerra (marzo, 1863) en el Madrid del joven Galdós». Bulletin of Spanish Studies, 86, 4. Liverpool: Liverpool University Press, pp. 459-474.

S. N. 1883. [Anuncio de Dona Perfecta]. Het nieuws van den dag: kleine courant. 4/10/1883, p. 8. Disponible en: http://resolver.kb.nl/resolve?urn=ddd:010065109: mpeg21:p008.

S. N. 1890a. [Anuncio de Marianela]. Venloosch weekblad. 17/05/1890, p. 4. Disponible en: http://resolver.kb.nl/resolve?urn=MMGAVL01:000002508:mpeg21:p004.

S. N. 1890b. «Boekenkennis. Marianela, van B. Perez Galdos, naar de zevende uitgave uit het Spaansch vertaald, door Una. Leiden. A. H. Adriani, 1890». Dietsche Warande. Nieuwe reeks 2. Jaargang 3, p. 548.

S. N. 1891. [Anuncio de Leon Roch en familie]. Nieuwsblad voor den boekhandel, 58 (82) 13-10-1891. Disponible en: http://resolver.kb.nl/resolve?urn=dts:2772083: mpeg21: 0001.

S. N. 1901a. "Kunst en Wetenschappen. Electra». Algemeen Handelsblad, 08-04-1901, p. 2. Disponible en: http://resolver.kb.nl/resolve?urn=ddd:010647070:mpeg2:p002. 
S. N. 1901b. [Anuncio de la publicación de la traducción de Electra]. Nieuwsblad voor den boekhandel, 68 (34) 26-04-1901, p. 194. Disponible en: http://resolver.kb.nl/ resolve?urn=dts:2880036:mpeg21:0001.

S. N. 1901c. «Verbetering». Nieuwsblad voor den boekhandel, 68 (35) 30-04-1901. Disponible en: http://resolver.kb.nl/resolve?urn=dts:2880037:mpeg21:0001.

S. N. 1901d. «Berichten en mededeelingen». De Nederlandsche Spectator, 27, 06-071901, pp. 211-212.

S. N. 1901e. «Kunst en Sport» [Anuncio de una representación de Electra en Bruselas]. Rotterdamsch nieuwsblad, 28-11-1901, p. 1. Disponible en: http://resolver.kb.nl/ resolve?urn=ddd:010179145:mpeg21:p011.

S. N. 1918. [Anuncio de Zuster Marcela entre libros antimilitaristas]. De wapens neder; maandorgaan van de Internationale Anti-Militaristische Vereeniging in Nederland. 14 (7). Disponible en: http://resolver.kb.nl/resolve?urn=MMVRED01:003057034 00001.

S. N. 1919. «Kleine stadslucht». Film-wereld, 2(48), p. 3. Disponible en: http:// bibliotheek.eyefilm.nl/bibis/other/Filmwereld/1919/Filmwereld_1919_048_r.pdf.

S. N. 1995. «Pocket praet». De Telegraaf, 01-10-1959, p. 9. Disponible en:http:// resolver.kb.nl/resolve?urn=ddd:110587656:mpeg21:p009.

SOPEÑA IBÁNÉEZ, Federico. 1970. Arte y sociedad en Galdós. Biblioteca Románica Hispánica, VII, Campo Abierto, 28. Madrid: Editorial Gredos.

STEENMEIJER, Maarten. 1980. «Eindelijk vertalingen van Benito Pérez Galdós». Literair paspoort, 31, pp. 751-755.

— 1999. "We weten alleen de oppervlakte». Vrij Nederland, 06-03-1999. Disponible en: https://www.mkw-uitgevers.nl/pema-vn.pdf.

— 2000. «Het Magnum Opus van een rasverteller». Vrij Nederland,16-09-2000. Disponible en: https://www.mkw-uitgevers.nl/pefo-vn.pdf.

— s. a. [Reseña de Miauw]. NBD Biblion. Disponible en: https://www.mkw-uitgevers. $\mathrm{nl} /$ pemi.html.

TEIXIDOR, Emili. «Literatura juvenil: las reglas del juego». CLIJ, LXXII, pp. 8-15.

TRANFAglia, Nicola y VITTORIA, Albertina. 2007. Storia degli editori italiani. Roma, Bari: Laterza.

TOURY, Gideon. 2012. Descriptive Translation Studies and Beyond. Ámsterdam y Filadelfia: John Benjamins.

TRILLING, Lionel. 1950. The Liberal Imagination. Nueva York: The Viking Press.

TRONCOSO, Dolores. 2006. «Introducción». Episodios nacionales. Segunda serie. La España de Fernando VII. Barcelona: Destino, pp. 7-19.

TURI, Gabriele. 1990. Casa Einaudi. Libri, uomini, idee oltre il fascimo. Bolonia: Il Mulino.

UREY, Diane Faye. 1982. Galdós and the Irony of Language. Cambridge Iberian and Latin American Studies. Cambridge: Cambridge University Press.

VAAN, Sander de. 1999. «De onverbiddelijke werkelijkheid». De Volkskrant, 08-01-1999.

Disponible en: https://www.mkw-uitgevers.nl/pema-vk.pdf. 
VAlera hervías, Eulogio. 1943. Cartas de Pérez Galdós a Mesonero Romanos. Madrid: Artes Gráficas Municipales.

VAREY, J. E. 1970. «Galdós in the Light of Recent Criticism». En Varey, J. E. (ed.) Galdós Studies. Londres: Tamesis Books, pp 1-35.

VÁZQUeZ MONTAlbán, Manuel. 1998. «Voordat Galdós Galdós was». En Pérez Galdós, 1878/1998, pp. 222-224.

VELZEN, Joost van. 2010. «Speuren naar vergeten Spaanse juwelen». Trouw, 28-07-10. Disponible en https://www.mkw-uitgevers.nl/mkw-trw.pdf.

venmans, Peter. 2000. «Roerige tijden in Madrid». De Volkskrant, 29-09-2000. Disponible en: https://www.volkskrant.nl/nieuws-achtergrond/de-onverbiddelijkewerkelijkheid -b9ed8817/.

— 2001. «De cultuur van de schone schijn». De Morgen, 07-11-2001, p. 29.

VENUTI, Lawrence. 1986. «The Translator's Invisibility» in Criticism, Spring 1986, vol. XXVIII, n. ${ }^{\circ}$ 2, pp. 179-212.

— 2007. «Traducción, empirismo, ética». En Navarro Domínguez, Fernando; Vega Cernuda, Miguel Ángel et al. (eds.) La traducción: balance del pasado y retos del futuro. Traducción de Javier Franco Aixelá. Alicante: Ed. Aguas Claras, pp. 99-120.

- 2008/1995. The Translator's Invisibility. A History of Translation. London, Nueva York: Routledge.

VILARÓs, Teresa M. 1995. Galdós, invención de la mujer y poética de la sexualidad: lectura parcial de Fortunata y Jacinta. Lingüística y Teoría Literaria. Madrid: Siglo XXI de España Editores.

VOGEL, Eberhard. 1910. Taschenwörterbuch der spanischen und deutschen Sprache. BerlínSchöneberg: Langenscheidt. Disponible en: http://d-nb.info/1132637163.

- 1911. Taschenwörterbuch der katalanischen und deutschen Sprache. Diccionari portàtil de les lléngues catalana y alemanya. Berlín-Schöneberg: Langenscheidt. Disponible en: http://d-nb.info/561003777.

- 1916. Taschenwörterbuch der katalanischen und deutschen Sprache. Diccionari portàtil de les lléngues catalana y alemanya. Berlín-Schöneberg: Langenscheidt. Disponible en: http://d-nb.info/561003777.

VOLLMANN, Rolf. 1998. "Auf Mauleseln durch die Mancha Einführung in die vergleichende Schlachtbeschreibung: Benito Pérez Galdós beschreibt die spanische Geschichte». FAZ. Frankfurter Allegemeine Zeitung, 32. Fráncfort del Meno. 07.02.1998.

VV. AA. 1994. Filosofía cristiana en el pensamiento católico de los siglos XIX y XX, tomo 2. Editada por Coreth S. J., Emerich; Neidl, Walter M.; Pfligersdorffer, George. Madrid: Encuentro Ediciones, p. 735.

WALLER, ELLEN. 1971. «De rijke eenvoud van Buñuels Tristana». NRC Handelblad, 2602-1972, CS p. 7. Disponible en: http://resolver.kb.nl/resolve?urn=KBNRC01: 000031521:mpeg21:p025.

WERNER, Elisabeth. 1913. Buona fortuna! Milán: Treves. 
WHISTON, James. 1999. Creatividad textual e intertextualidad en Galdós. Ottawa Hispanic Studies, 22. Ottawa: Dovehouse Editions / University of Ottawa.

WILLEM, Linda M. 2019. «El amor, la ceguera y el racismo: una adaptación norteamericana de Marianela». La hora de Galdós. Actas XI Congreso Internacional de Estudios Galdosianos. Las Palmas de Gran Canaria: Cabildo de Gran Canaria, pp. 876-885.

WINTER, Ulrich. 2012. «Images of Time: Paradigms of Memory and the Collapse of the Novel of Contemporary History in Spain (2000-2010)». Hispanic Issues on Line, 11. Disponible en: https://cla.stg.umn.edu/sites/cla.umn.edu/files/hiol_11_01_winter_ images_of_time.pdf.

WOLfF, Emil. 1880. Carta número 175, de 30 de abril de 1880. Las Palmas de Gran Canaria: Casa-Museo Pérez Galdós.

YNDURÁIN, Francisco. 1970. Galdós: entre la novela y el folletín. Cuadernos Taurus, 98. Madrid: Taurus Ediciones.

ZACCARIA, Giuseppe. 1984. La fabbrica del romanzo, 1861-1914. Ginebra-París: Editions Slatkine.

Zambrano, María. 1989. La España de Galdós. Ensayos. Madrid: Ediciones Endymion.

ZARANDONA, Juan Miguel. 2019. «Pérez Galdós (1843-1920) y el retorno de la materia de Bretaña a las letras españolas: Tristana (1892) y El caballero encantado (cuento real... inverosimil) (1909)». En Arencibia, Yolanda; Gullón, Germán; Galván González, Victoria et al. (eds.) La hora de Galdós. Actas del XII Congreso Internacional de Estudios Galdosianos. Las Palmas de Gran Canaria: Cabildo de Gran Canaria, pp. 681-705.

ZHAO, Zhenjiang. 2009. «La literatura española en China». Centro Virtual Cervantes. Disponible en: https://cvc.cervantes.es/obref/china/zhenjiang.htm.

\section{FILMOGRAFÍA}

Tristana. BuÑUEL, Luis. 1970. Época Films, Talía Films, Selenia Cinematográfica, Les Films Corona.

Tormento. OlEA, Pedro. 1974. José Frade Producciones Cinematográficas. 



\section{BIOGRAFÍAS}

La directora de la colección Tibón: Estudios Traductológicos y el coordinador del volumen quieren dejar el agradecimiento expreso a los investigadores internacionales que respondieron a la llamada de la publicación de este volumen colectivo dedicado en exclusiva a la traducción y a la recepción de la obra de don Benito Pérez Galdós con motivo del primer centenario de su fallecimiento. Gracias por su entusiasmo ante este reto y su amable disponibilidad para hacerlo posible.

\section{LIEVE BEHIELS}

lieve.behiels@kuleuven.be

\section{KU Leuven, Bélgica}

Lieve Behiels es doctora en letras por la Universidad de Gante. Es profesora emérita de la Facultad de Letras de la KU Leuven. Ha enseñado clases de historia y literatura española e hispanoamericana, traducción e interpretación. Sus campos de investigación son la literatura española de los siglos XIX y XX, la imagología y los estudios históricos de la traducción. Cuenta con numerosas publicaciones en todos estos campos, entre otras La cuarta serie de los Episodios Nacionales de Benito Pérez Galdós: una aproximación temática y narratológica (Madrid / Frankfurt: Iberoamericana-Vervuert, 2001). También ha vertido varios ensayos al espańol. Recientemente ha traducido De los tiempos turbulentos en los Países Bajos y sobre todo en Gante. Flandes en vísperas de la Guerra de los Ochenta Años de Marcus van Vaernewijck (Valladolid: Ediciones de la Universidad de Valladolid, 2018). Desde 2016, es miembro correspondiente de la Real Academia Española.

\section{AMALIA BOSCH BENÍTEZ}

amalia.bosch@ulpgc.es

\section{Universidad de Las Palmas de Gran Canaria, España}

Amalia Bosch Benítez estudia Filología Alemana en la Universidad Complutense. Accede en 1993 como profesora a la Universidad de Las Palmas de Gran Canaria, donde imparte clases de traducción y de interpretación tanto de alemán como de inglés. Su tesis doctoral versó sobre la traducción de la novela histórica. Su actividad como traductora literaria e intérprete profesional se desarrolló en Madrid. Trabajó para la Editorial Debate en la versión espańola de los cuentos de Babar y, posteriormente, en la traducción de la obra de escritores en lengua alemana como Siegfried Lenz y Leo Perutz. Imparte exclusivamente clases de interpretación simultánea desde hace unos años en la 
ULPGC. Su campo de investigación está enfocado a la didáctica con especial interés en la empatía como motor de anticipación en la producción del discurso.

\section{PILAR MARTINO ALBA}

pilar.martino@urjc.es

\section{Universidad Rey Juan Carlos, Madrid, España}

Pilar Martino Alba es doctora en Historia del Arte por la U. Complutense de Madrid y doctora en Traducción e Interpretación por la U. de Alicante. Máster Universitario en Traducción de textos con fines específicos, traducción y doblaje alemán-español por la U. de Sevilla. Profesora Titular en la URJC. Docente del Máster de Traducción de la U. Ricardo Palma, Lima. Ha sido docente de Teoría y Metodología de la Traducción en el Instituto Universitario de Lenguas Modernas y Traductores de la U. Complutense durante tres lustros. Profesora visitante en la U. de Münster, becada por el DAAD y en la Hochschule Magdeburg-Stendal. Becada por el Istituto Italiano di Cultura (Laboratorio Internazionale della Comunicazione). Autora de medio centenar de artículos y editora y/o coeditora de varias monografías en torno a la traducción; ejerce la traducción literaria. Es miembro cofundador del grupo de investigación MHISTRAD/TRADEC. Ha participado en varios proyectos de investigación I+D sobre traducción.

\section{ASSUNTA POLIZZI}

assunta.polizzi@unipa.it

\section{Università degli Studi di Palermo, Italia}

Assunta Polizzi es profesora de la Universidad de Palermo. Su especialidad gira en torno al ámbito de la Filología hispánica de las épocas moderna y contemporánea: poesía y novela espańola contemporánea, traducción literaria, prensa y cultura, etc. Buena parte de su investigación ha estado dedicada a la obra y figura de Benito Pérez Galdós, por ejemplo, su tesis doctoral titulada: El proceso metafictivo en el realismo de Galdós. Esta tesis recibió el Premio Internacional de Investigación Pérez Galdos del año 1996, concedido por la Casa-Museo Pérez Galdós y el Servicio de Cultura del Cabildo Insular de Gran Canaria. Son numerosos sus estudios y publicaciones, proyectos de investigación o traducciones en torno al escritor grancanario, campo de estudio dentro del cual que se ha convertido en una gran especialista internacional, como su análisis de la censura en la traducción italiana de Fortuna y Jacinta, de 2003, o su traducción La diseredata de 2011.

\section{JUAN MIGUEL ZARANDONA \\ juanmiguel.zarandona@uva.es \\ Universidad de Valladolid, España}

Juan Miguel Zarandona es profesor de traducción en la Facultad de Traducción e Interpretación de Soria, Universidad de Valladolid. Licenciado en Filología por esta uni- 
versidad, completó su formación con un posgrado en traducción por la Universidad de Sudáfrica (UNISA). Doctor por la Universidad de Zaragoza con una tesis sobre la recepción española del poeta británico Alfred Lord Tennyson y sobre el canon con temporáneo de literatura artúrica española, incluido Pérez Galdós. Sus principales líneas de investigación giran en torno a los Estudios Artúricos y Estudios Africanos, cuyos resultados, siempre orientados hacia la traducción, pueden consultarse en la página de dos grupos de investigación que dirige: Afriqana (www.afriqana.org) y Clytiar (www. clytiar.org), integrados en el GIR TradHuc (www.uva.es/tradhuc) [Traducción Humanística y Cultural]. Es director del Proyecto Hermēneus, compuesto de tres colecciones: la revista Hermèneus de TeI, los monográficos Vertere y Disbabelia o serie de traducciones ignotas.

\title{
TONI DORCA
}

dorca@macalester.edu

\section{Macalester College, Estados Unidos}

Toni Dorca se doctoró en Filología hispánica por la Universidad de California, Davis en 1993. Desde 2005 es catedrático en el Departamento de Español y Portugués en Macalester College. Su investigación reciente se ha centrado en la novelística histórica de Benito Pérez Galdós, en particular las relaciones entre historia, nación y narración. Fruto de esta investigación es el libro Las dos caras de Jano: la guerra de la Independencia como materia novelable en Galdós (Iberoamericana, 2015). En la actualidad está trabajando en una monografía acerca de la segunda serie de Episodios nacionales de Benito Pérez Galdós. Diversos estudios en torno a este grupo de novelas han aparecido, o están en prensa, en revistas académicas y monografías conjuntas producto de congresos y homenajes. A partir del 1 de mayo de 2020 va a ocupar el cargo de director de la revista Anales Galdosianos.

\section{ISABEL PASCUA FEBLES}

\author{
isabel.pascua@ulpgc.es
}

\section{Universidad de Las Palmas de Gran Canaria. España}

Isabel Pascua Febles, licenciada en Filología Inglesa por la Universidad de la Laguna y doctora en Traducción por la Universidad de Las Palmas de Gran Canaria, es profesora titular de la Facultad de Traducción e Interpretación. Su docencia se ha centrado en traducción literaria y teorías de la traducción. Ha sido la primera decana de la Facultad de Traducción e Interpretación, directora de programas de doctorado y vicerrectora de Cultura de su Universidad. Sus principales líneas de investigación se centran en la traducción de literatura para el público infantil y juvenil y temas sobre la mujer. Es autora o editora de 18 libros, además de unos 80 artículos y capítulos en libros y revistas nacionales e internacionales. Ha traducido a Riitta Oittinen y varios libros de viaje sobre los ingleses en Canarias. Actualmente se ocupa de la dirección editorial de la nueva colección de monografías Tibón. Estudios Traductológicos, de la Universidad de Las Palmas de Gran Canaria. 


\section{MARÍA ISABEL GARCÍA BOLTA}

garciabolta@gmail.com

\section{Las Palmas de Gran Canaria}

María Isabel García Bolta es doctora en Filosofía y Letras con el trabajo Galdós y sus lectores. Catedrática de Bachillerato de Lengua y Literatura Españolas, y, con posterioridad, Coordinadora Técnica de Archivos y Bibliotecas. Nombramientos: Presidenta de la Sociedad de Estudios Galdosianos, Secretaria de la Comisión Regional del V Centenario América 1992 y vocal de la Asociación Europea de Enseñantes. Es miembro del Instituto de Estudios Canarios. Publicaciones: Santa Teresa, la mujer escritora (1982); El lector de las novelas contemporáneas de Pérez Galdós (1984); Un personaje de Pérez Galdós: el lector ficción (1985); Catálogo de Ediciones Canarias (1988); La mujer en la sociedad galdosiana (1989); Los lectores de Pérez Galdós (1989); Pérez Galdós fuera de España (1993); Galdós editor (1995). Autora de artículos sobre Pérez Galdós, Gracián, el poeta Francisco Martínez Miret y Ángel Guimerá. Ponente en congresos y simposios.

\section{MARIE-CLAIRE DURAND GUIZIOU}

marieclaire.durand@ulpgc.es

\section{Universidad de Las Palmas de Gran Canaria. España}

Marie-Claire Durand Guiziou fue profesora titular de Universidad de la ULPGC en la Facultad de Traducción e Interpretación hasta 2012. Cuenta con numerosas publicaciones (libros, capítulos de libros, artículos), traducciones y reseñas, relacionadas con la literatura francesa y española, así como antologías bilingües de literatura francófona y obras sobre el aprendizaje de la traducción de la prensa. Ha sido miembro activo de comités científicos de revistas nacionales e internacionales, entre ellas Les Cabiers Max Jacob, (Francia). En 2014 publicó una obra crítica, Max Jacob et la nomination (París, 2014). Desde hace más de una década dirige la colección «Lettres canariennes» de la editorial L'Harmattan de París, con el objetivo prioritario de facilitar la traducción y publicación en francés de obras españolas emanadas de autores nacidos en las Islas Canarias, tantos clásicos como contemporáneos. Colabora con el grupo de investigación «Actividad translatoria, interculturalidad y literatura de viajes» de la ULPGC.

\section{LISA NALBONE}

lisa.nalbone@ucf.edu

\section{University of Central Florida, Estados Unidos}

Lisa Nalbone ha sido coeditora de Intersections of Race, Class, Gender, and Nation in Finde-Siècle Spanish Literature and Culture (Routledge, 2016) y autora de The Novels of Carmen Conde: Toward an Expression of Feminine Subjectivity (Juan de la Cuesta, 2012). Sus investigaciones se centran en la literatura y cultura españolas de finales del siglo XIX al siglo XX, dentro y fuera de la Península, y examinan las representaciones socioculturales de la feminidad al igual que la relación entre la modernidad y cuestiones de género, construcciones sociales, y convenciones políticas durante la transición hacia la modernidad. 


«Imagen de la vida es la novela, y el arte de componerla estriba en reproducir los caracteres humanos, las pasiones, las debilidades, lo grande y lo pequeño, las almas y las fisonomías, todo lo espiritual y lo físico que nos constituye y nos rodea, y el lenguaje, que es la marca de la raza, y las viviendas, que son el signo de familia, y la vestidura, que diseńa los últimos trazos externos de la personalidad: todo esto sin olvidar que debe existir perfecto fiel de balanza entre la exactitud y la belleza de la reproducción».

Discursos leidos ante la Real Academia Española en la recepción pública del Sr. D. Benito Pérez Galdós el domingo 7 de febrero de 1897. Madrid. Est. Tip. de la viuda e hijos de Tello. Impresor de cámara de S. M. C. de San Francisco, 4. 1897.

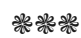

«Los dos únicos novelistas vivos que me gustan en absoluto son usted y Zola. ¿Qué le falta a usted? Muchas cosas que tiene Zola. ¿Y a Zola? Muchas que tiene usted ¿Y a los dos? Algunas que tenía Flaubert. ¿Y a los tres? Algunas que tenía Balzac. ¿Y a Balzac? Otras que tienen ustedes tres.

Pero eso jes faltar? No, eso es ser finito, eso es ser quien se es».

Carta de Clarín a Pérez Galdós, de 15-03-1984, en Cartas a Galdós. Ed. de Soledad Ortega. Madrid. Revista de Occidente. 1964. 
La celebración de los cien años del fallecimiento de Benito Pérez Galdós en 1920 se encuentra detrás del impulso que anima a este libro. Para llevar a cabo su mejor homenaje, los participantes en esta empresa editora han tenido en cuenta dos realidades: tanto la realidad de que no existen unas obras completas traducidas de Galdós en ninguna lengua, como aquella que atestigua que el volumen de textos de don Benito traducidos a las lenguas más insospechadas es una riqueza que merece hoy en día y merecerá en años próximos un análisis mucho más completo y atento por parte de los estudiosos galdosianos. Pero la traducción no incluye la herencia cultural y literaria completa del maestro. Este libro también busca asomarse a un fenómeno mucho más amplio, la recepción o reescritura de la obra de nuestro autor, lo que incluye denominaciones tales como la adaptación, la apropiación, la imitación, la inspiración, el pastiche, la crítica, etc., además de todas las amplias posibilidades que se albergan bajo la denominación de traducción. En consecuencia, el lector interesado en este esfuerzo, que busca ser el primero de otros muchos muy necesarios, encontrará desde testimonios únicos de la llegada de Pérez Galdós a los ámbitos lingüísticos neerlandés, alemán, italiano o inglés, hasta Almudena Grandes y Galdós, una completa bibliografía específica de traducciones de don Benito o la traducción del cuento Rompecabezas, por primera vez, al francés y al inglés 